\title{
AS PARCERIAS EM PROGRAMAS DE COLETA SELETIVA DE RESÍDUOS SÓLIDOS DOMÉSTICOS
}

\author{
ALEXANDRE AGUIAR
}

Dissertação Apresentada à Faculdade de Saúde Pública da Universidade de São Paulo para a Obtenção do Título de Mestre

Área de Concentração: Saúde Ambiental

Orientador: Prof. Dr. Arlindo Philippi Jr. 
ATA DA SESSÃO PÚBLICA DE ARGÜIÇÃO E DEFESA DA DISSERTAÇÃO DE MESTRADO APRESENTADA PELO CANDIDATO AO TITULO DE "MESTRE EM SAÚDE PÚBLICA" ÁREA DE CONCENTRAÇĀO SAÚDE AMBIENTAL ALEXANDRE DE OLIVEIRA E AGUIAR

Aos dezesseis dias do mês de dezembro de 1999, às 14 hotas, realizou-se na Sala Prof. Walter Belda da Faculdade de Saúde Pública da Universidade de São Paulo, a sessão pública para argüição e defesa da dissertação intitulada “AS PARCERIAS EM PROGRAMAS DE COLETA SELETIVA DE RESÍDUOS SÓLIDOS DOMÉSTICOS", apresentada por Alexandre de Oliveira e Aguiar, candidato ao título de "Mestre em Saúde Pública" - área de concentração Saúde Ambiental. A Comissão Julgadora foi constituída pelos membros Professor Alcides Lopes Leão - Departamento de Ciências Ambientais/UNESP/Botucatu, Professora Aracy Witt de Pinho Spínola Departamento de Prática de Saúde Pública da FSPIUSP e Professor Arlindo Philippi Jr - Departamento de Saúde Ambiental da FSP/USP (Orientador e Presidente da Comissão). A Comissão Julgadora passou à arguição pública do candidato. Encerrados os trabalhos de argüição, os examinadores deram o parecer final, tendo o mesmo respondido com segurança às questões levantadas, demonstrando domínio do tema desenvolvido, caracterizando-se um desempenho digno de destaque.

Professor Doutor Alcides Lopes Leão Aprovado(a) Reprovado Professora Titular Aracy Witt de Pinho Spínola Aprovado(a) Reprovado Professor Doutor Arlindo Philippi Jr Aprovado(a) $\mathbb{R}$ Reprovado

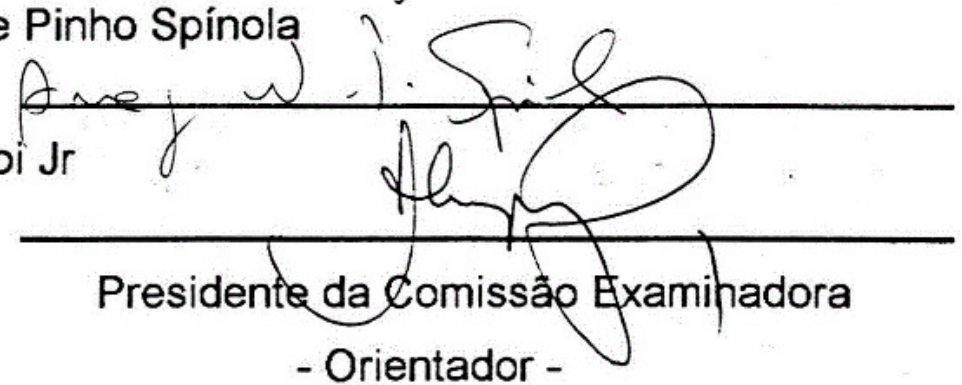




\title{
AS PARCERIAS EM PROGRAMAS DE COLETA SELETIVA DE RESÍDUOS SÓLIDOS DOMÉSTICOS
}

\author{
ALEXANDRE AGUIAR
}

Dissertação Apresentada à Faculdade de Saúde Pública da Universidade de São Paulo para a Obtenção do Título de Mestre

Área de Concentração: Saúde Ambiental

Orientador: Prof. Dr. Arlindo Philippi Jr. 
Autorizo, exclusivamente para fins acadêmicos e científicos, a reprodução total ou parcial desta dissertação, por processos fotocopiadores.

Assinatura:

Data: $16 / 12 / 99$ 
Aos meus pais, que são verdadeiros mestres. 


\section{AGRADECIMENTOS}

Sou grato aos que diretamente contribuíram para o trabalho: os profissionais que me receberam e muito me ensinaram nas visitas técnicas e nas entrevistas, ou então que facilitaram o acesso aos dados. Em especial agradeço a Washington Novaes, Vera Lúcia Cardoso, Gina Bensen "Rizpah", Regina Siqueira da Silva, Carlos Eduardo Abrahão, Fábio Cardoso, Izabela Regueira e aos cooperados da COOPERMAPE e da COOPREC. Os mestres: Prof. Dr. Arlindo Philippi Jr., que abriu a primeira porta ao me aceitar como seu orientado, e que depois tantas portas mais abriu. Prof. Dr. Alcides Leão e Profa. Dra. Aracy Witt de Pinho Espinola, pelo apoio e sugestões. Agradeço também à FAPESP, pelos recursos concedidos.

Mas seria injusto ser tão específico. Há outras pessoas que contribuíram de outras formas com o sucesso do trabalho.

Meus pais, Geny e Moysés, de quem herdei o gosto pelo estudo e de quem sempre tive apoio, apesar das dificuldades e desencontros da vida.

Outros profissionais que colaboraram. Prof. Dr. Carlos Zahn, Prof. Dr. José M. S. Barata, Profa Maria da Penha Vasconcelos. Os funcionários: Renilda e Cidinha da CPG, Maria Lúcia, Sueli, Roberta e Ângela da biblioteca, Angelino e seus funcionários da copiadora e tantos outros cujos nomes não caberiam nesta folha.

Há também os colegas e amigos. Dr. Marcel Bergerman e Dra. Cida Pinhal, que serviram de exemplo e de incentivo. Alex Aaltonen, colega de copo, e um pouco também de cruz, na hora de decidir por uma pós-graduação. Há aqueles que com paciência ouviram o pensar alto pouco compreensível do início e os desabafos das dificuldades intermediárias, cujas sugestões foram decisivas ou que com sua amizade tornaram o caminho mais agradável: Claudia Ruberg, Ivan Maglio, Cintia P. Salles, Vânia Marcelo, Alexandra Frasson, Francisco Hernandez-Torres, Alda M. P. Costa, Rosilda Motta, Nélia Callado, Leiko Asakura, Ana Luiza Vilela Borges, Joyce Araújo, Raquel Souzas, Cynthia Pimenta, Eduardo Coutinho, Claudia Deker, Andreia Capeletti, Alessandra Lucca, Renata Albano, Bettina Brasil, Patricia Jaime, Alex Florindo, Luiz Lourena, Luis Paulo Pimentel, Marcia Simões, Daniele Pompei Sacardo, Solange, Adriana, Luis Claudio, e mais uma lista imensa ...

E com carinho todo especial agradeço a Henriette Helfant, que tem me acompanhado com dedicação extrema e que me dá muita força.

A todos vocês, muitíssimo obrigado! 


\section{RESUMO}

Aguiar A. As parcerias em programas de coleta seletiva de resíduos sólidos domésticos. São Paulo; 1999. [Dissertação de Mestrado - Faculdade de Saúde Pública da USP].

Objetivo. Estudar experiências de gerenciamento de resíduos sólidos domésticos envolvendo parcerias, identificando pontos positivos e negativos nas relações inter-institucionais, e verificando a relação entre os dados da bibliografia e o constatado nos programas estudados. Métodos. Foram realizados estudos de caso de programas de coleta seletiva em Goiânia (GO), Campinas (SP), Embu (SP), Santos (SP) e Botucatu (SP). Foram feitas entrevistas e visitas técnicas em entidades envolvidas, incluindo órgãos do governo, empresas e ONGs. Os programas foram analisados nos aspectos sócio-ambiental, operacional, econômica e políticoinstitucional. Resultados. As taxas de desvio observadas variaram entre 0,1 e 2,39\% e as taxas de recuperação entre 1,67 e $7,82 \%$. Os custos totais dos programas estiveram entre US\$ 150 e US\$ 650 por tonelada recuperada. Os custos de coleta representam entre 19 e $82 \%$ e os custos de triagem entre 14 e $52 \%$. As dificuldades mais freqüentes relatadas pelos entrevistados são relacionadas aos aspectos humanos: comportamentais, políticos e educacionais. Conclusões. As parcerias podem disponibilizar recursos financeiros, equipamentos, materiais diversos e mão-de-obra para a implementação de programas de coleta seletiva. As parcerias são uma forma eficiente de redução de custos dos programas. Diversos programas municipais têm desenvolvido parcerias para a operação de triagem. As iniciativas espontâneas desempenham um papel importante e devem ser incentivadas. Os investimentos em recursos humanos e os incentivos às indústrias locais de reciclagem são fatores-chave do sucesso dos programas. A reciclagem de lixo constitui-se uma alternativa importante de atividade econômica, com geração de emprego e renda. A pesquisa foi apoiada pela FAPESP.

Descritores: Lixo. Resíduos Sólidos. Coleta seletiva de Resíduos. Reciclagem de Lixo. Parcerias. Gerenciamento de Resíduos. Participação Comunitária. 


\section{SUMMARY}

Aguiar A. As parcerias em programas de coleta seletiva de resíduos sólidos domésticos. [Partnerships in domestic waste segregative collection programs]. São Paulo (BR); 1999. [Dissertação de Mestrado - Faculdade de Saúde Pública da USP].

Objective. To study domestic solid waste management experiences through partnerships, identifying strengths and weaknesses in inter-institutional relationships and verifying the concordance between bibliography recommendations and the studied programs characteristics. Methods. Segregative collection and recycling programs cases were studied in the following cities: Goiânia (GO), Campinas (SP), Embu (SP), Santos (SP) e Botucatu (SP). Technical visits and interviews were accomplished in institutions involved, including government offices, companies and NGOs. Programs were analysed in social-environmental, operations, economics and political-institutional features. Results. Decipe rates varied between 0,1 e 2,39\% and recovery rates between 1,67 and $7,82 \%$. Programs' total costs ranged from US\$ 150 to R $\$ 650$ per recovered metric ton . Collection costs were between 19 and $82 \%$ and sorting costs between 14 to $52 \%$. The most frequent difficulties described in interviews were those related human features: behavior, policy and education.

Conclusions. Os investimentos em recursos humanos e os incentivos às indústrias locais de reciclagem são fatores-chave do sucesso dos programas. A reciclagem de lixo constitui-se uma alternativa importante de atividade econômica, com geração de emprego e renda. Partnerships can contribute to obtain financial and human resources, equipment and several materials to the implementation of segregative collection programs. They are an efficient way to reduce costs of programs. Several municipal programs develop partnerships in the operation of sorting. Equipment and buildings continue being financed by municipality. The spontaneous initiatives play an important role and should be encouraged. Investiments in human resources and incentives to local industries are key factors to the success of programs. Garbage recycling is an important alternative economic activity to bring employment and income. Research supported by FAPESP

Descriptors: Garbage. Solid Waste. Waste Recycling. Garbage Segregative Collection. Partnerships. Waste Management. Community Participation. 



\section{INDICE}

1. INTRODUÇÃO 1

2. OBJETIVOS 4

3. CONCEITOS E FUNDAMENTAÇÃO TEÓRICA

3.1. Resíduos Sólidos: Definição e classificação 5

3.2. Geração de resíduos sólidos domésticos 7

3.3. Questões ambientais e de saúde pública associada aos resíduos sólidos 9

3.4. Sistema de Limpeza Pública e Sistema de Resíduos Sólidos 12

3.5. Os setores da sociedade e os seus papéis 13

3.5.1 O Estado 14

3.5.2. O setor de produção 16

$\begin{array}{ll}\text { 3.5.3. O terceiro setor } & 17\end{array}$

3.6. Educação Ambiental 18

3.7. Parcerias 19

3.8. Desenvolvimento Sustentável e Agenda $21 \quad 20$

4. MÉTODOS E TÉCNICAS 23

4.1. Atividades prévias 23

4.2. Modelo de análise $\quad 24$

4.3. Seleção dos programas a analisar $\quad 26$

4.4 Programação das entrevistas e visitas técnicas. 27

4.5. Atividades de campo 28

4.6. Análise dos resultados 30

4.6.2. Dimensão operacional $\quad 30$

4.6.3. Dimensão econômica 31

4.6.4. Dimensão político-institucional 31

4.6.1. Dimensão sócio-ambiental 31

5. ASPECTOS TÉCNICOS E ECONÔMICOS DO GERENCIAMENTO 33 DE RESÍDUOS SÓLIDOS DOMÉSTICOS

5.1. Sistemas de resíduos sólidos: aspectos técnicos 33

$\begin{array}{ll}\text { 5.1.1. Acondicionamento } & 33\end{array}$

$\begin{array}{ll}\text { 5.1.2. Coleta } & 34\end{array}$

5.1.3. Transporte 36

5.1.4. Tratamento 37

5.1.5. Disposição final 42

5.1.6. Os quatro "R"

5.2. Aspectos econômicos e análise custo-benefício 47

5.2.1. Custos unitários globais da coleta seletiva 49

5.2.2. Componentes dos custos de coleta e triagem 50

5.2.3. Indicadores do mercado de materiais recicláveis 51 
6.1. Experiências e tendências internacionais

6.1.1. Alemanha: o sistema dual $\quad 52$

6.1.2. Grã-Bretanha: em busca dos investidores privados 55

6.1.3. Estados Unidos: o mercado regulando a reciclagem 55

$\begin{array}{ll}\text { 6.1.4. Outras experiências } & 56\end{array}$

6.2. Experiências brasileiras: dez anos de coleta seletiva organizada 58

$\begin{array}{ll}\text { 6.2.1. Belo Horizonte } & 59\end{array}$

$\begin{array}{lr}\text { 6.2.2. Porto Alegre } & 60\end{array}$

$\begin{array}{ll}\text { 6.2.3. Outros projetos } & 61\end{array}$

$\begin{array}{ll}6.3 \text { Recomendações de estudos anteriores } & 63\end{array}$

6.3.1. Lixo Municipal: Manual de Gerenciamento Integrado (JARDIM e 63 col. 1995)

6.3.2. Agenda 21 (CNUMAD 1992) 64

7. ESTUDOS DE CASO - RESULTADOS DE CAMPO 66

7.1. Goiânia $\quad 66$

$\begin{array}{ll}\text { 7.1.1. A cidade } & 66\end{array}$

$\begin{array}{ll}\text { 7.1.2. A coleta seletiva } & 67\end{array}$

$\begin{array}{ll}\text { 7.1.3. As parcerias } & 71\end{array}$

$\begin{array}{ll}\text { 7.2. Campinas } & 72\end{array}$

$\begin{array}{ll}\text { 7.2.1. A cidade } & 72\end{array}$

$\begin{array}{ll}\text { 7.2.2. A coleta seletiva } & 73\end{array}$

7.3.3. As parcerias $\quad 76$

7.3. Embu

77

$\begin{array}{ll}\text { 7.2.1. A cidade } & 77\end{array}$

$\begin{array}{ll}\text { 7.2.2. A coleta seletiva } & 78\end{array}$

$\begin{array}{ll}\text { 7.3.3. As parcerias } & 81\end{array}$

$\begin{array}{ll}\text { 7.4. Santos } & 82\end{array}$

$\begin{array}{ll}\text { 7.2.1. A cidade } & 82\end{array}$

$\begin{array}{ll}\text { 7.2.2. A coleta seletiva } & 83\end{array}$

$\begin{array}{lr}\text { 7.3.3. As parcerias } & 85\end{array}$

7.5. Botucatu

86

$\begin{array}{lr}\text { 7.2.1. A cidade } & 86\end{array}$

$\begin{array}{ll}\text { 7.2.2. A coleta seletiva } & 87\end{array}$

$\begin{array}{lr}\text { 7.3.3. As parcerias } & 90\end{array}$

8. DISCUSSÃO

8.1. Dimensão operacional / tecnológica 92

8.1.1. Coleta Seletiva $\quad 92$

$\begin{array}{ll}\text { 8.1.2. Triagem dos resíduos } & 95\end{array}$

$\begin{array}{lr}\text { 8.1.3. Processamento industrial } & 97\end{array}$

8.1.4. Outros aspectos $\quad 99$ 
8.2. Dimensão econômica 100

8.2.1. Custos de coleta e transporte 101

$\begin{array}{ll}8.2 .2 \text {. Custos de triagem } & 105\end{array}$

8.2.3. Industrialização dos materiais 108

8.2.4. Custos Unitários totais 109

8.2.5. O mercado de recicláveis 113

8.2.6. Viabilidade Econômica 117

8.3. Dimensão político-institucional $\quad 120$

8.3.1. Envolvimento das instituições nos programas 120

8.3.2. Comentários gerais sobre articulação iterinstitucional 126

8.3.3. Principais dificuldades e soluções 129

8.4. Dimensão sócio-ambiental 132

8.1.1. Os materiais recuperados dos resíduos 133

8.1.2. Desvio de resíduos e recuperação de materiais 134

8.1.3. Vetores transmissores de doenças 138

8.1.4. Impacto social, educativo e participação da comunidade 139

8.5. Situação em relação às recomendações de trabalhos anteriores 142

8.5.1. Agenda $21 \quad 142$

8.5.2. "Lixo Municipal - Manual de Gerenciamento integrado" 146

9. AS PARCERIAS E A VIABILIZAÇÃO DOS PROGRAMAS DE COLETA SELETIVA

9.1. Requisitos para implementação de programas de coleta seletiva $\quad 150$

9.2. O papel dos diferentes setores 154

10. CONSIDERAÇÕES FINAIS

REFERÊNCIAS BIBLIOGRAFICAS

BIBLIOGRAFIA COMPLEMENTAR CONSULTADA 173

ANEXOS
Anexo 1 - Roteiro para entrevistas
Anexo 2 - Fórmulas para cálculo de indicadores
Anexo 3 - Resumos das relações inter-institucionais nos programas
Anexo 4 - Resumos dos fluxos de material nos programas
Anexo 5 - Dados tabulares das entrevistas
Anexo 6 - Resumos dos aspectos econômicos - custos
Anexo 7 - Material de divulgação dos programas
Anexo 8 - Modelos de cartas de apresentação e de consentimento esclarecido 


\section{LISTA DE TABELAS}

CAPÍTULO 3

Pág.

Tabela 3.1. Composição percentual em peso dos resíduos sólidos

domésticos gerados no município de São Paulo, em vários

anos.

Tabela 3.2. Composição dos resíduos sólidos domésticos em

porcentagem de peso em algumas cidades do Brasil em 1992/93.

Tabela 3.3. Exemplos de doenças transmitidas por vetores associados aos resíduos sólidos domésticos.

\section{CAPÍTULO 5}

Tabela 5.1. Custos de diferentes opções de tratamento e disposição final de resíduos sólidos em diversos países, em US\$ / t.

\section{CAPÍTULO 7}

Tabela 7.1. Número de entidades entrevistadas e visitadas 66

Tabela 7.2. Investimentos realizados no Projeto Meia Ponte (Goiânia 68

- GO)

\section{CAPÍTULO 8}

Tabela 8.1. Eficiência de utilização de recursos humanos e veículos na coleta seletiva de resíduos sólidos domésticos em vários municípios.

Tabela 8.2. Eficiência da mão-de-obra de triagem em programas de coleta seletiva em diversos municípios brasileiros

Tabela 8.3. Quantidade estimada de rejeitos da coleta seletiva em vários municípios

Tabela 8.4. Preços de venda médios dos materiais recicláveis em diversos municípios, em R $\$ / t$.

Tabela 8.5. Comparação com a coleta regular municipal - Aspectos econômicos do ponto de vista da Prefeitura Municipal

Tabela 8.6. Taxas de desvio e de recuperação observadas nos estudos de caso.

Tabela 8.7. Taxas de desvio e recuperação observadas em outras

Tabela 8.8. Coleta regular e seletiva de resíduos domésticos per capita 


\section{LISTA DE FIGURAS}

CAPÍTULO 3

Figura 3.1. Diagrama esquemático de algumas definições utilizadas 6

Figura 3.2. Vias de contato do homem com o lixo 10

\section{CAPÍTULO 5}

Figura 5.1. Coleta informal de resíduos sólidos em São Paulo (SP) . 35

Figura 5.2. Lixeiras feitas de pneus usados (Alagoinha - PB) 39

Figura 5.3. Compostagem em montes (Alagoinha-PB) 40

Figura 5.4. Incineração de resíduos de serviços de saúde (São José dos 40 Campos - SP)

Figura 5.5. Disposição final de resíduos sólidos domésticos 43

Figura 5.6. Diagrama de fluxo simplificado de um sistema de 44 gerenciamento integrado de resíduos sólidos

Figura 5.7. Garrafas recolhidas de resíduos sólidos domésticos prontas 46 para serem retornadas a fabricantes de bebidas (São José dos Campos - SP).

\section{CAPÍTULO 6}

Figura 6.1. O "Ponto Verde" 53

Figura 6.2. Programas de coleta seletiva em municípios brasileiros 58 segundo grandes regiões

Figura 6.3. Contêineres de entrega voluntária - São Paulo 1998

\section{CAPÍTULO 7}

Figura 7.1. Vista geral do Núcleo Industrial de Reciclagem 69

Figura 7.2. Algumas Atividades do Núcleo Industrial de Reciclagem $\quad 70$

Figura 7.3. Algumas Atividades da Coleta Seletiva em Campinas 74

Figura 7.4. A coleta seletiva em Embu 79

Figura 7.5. Galpão de triagem da PRODESAN 84

Figura 7.6. Sede da Associação dos Carrinheiros de Santos 85

Figura 7.7. Um dos espaços utilizados para armazenamento de papel 87 para reciclagem no Campus Rubião

Figura 7.8. Posto de Entrega Voluntária - Campus Lageado 88 


\section{INTRODUÇÃ̃O}

A produção de resíduos sólidos faz parte do cotidiano do ser humano. Não se pode imaginar um modo de vida que não gere resíduos sólidos. Devido ao aumento da população humana, à concentração dessa população em centros urbanos, à forma e ao ritmo da ocupação desses espaços e ao modo de vida baseado na produção e consumo cada vez mais rápidos de bens, os problemas causados por esses resíduos tendem a se tornar mais visíveis.

Como problema urbano, a destinação dos resíduos sólidos data, no Brasil, da época colonial (ROCHA 1992), não sendo portanto uma preocupação nova. As implicações ambientais mais graves e de saúde pública já eram reconhecidas no início do século pelos administradores municipais paulistanos. Naquela época alguns dos principais problemas eram o uso do lixo in natura como adubo pelos chacareiros e a deposição dos resíduos nas margens do rio Tietê. O problema dos resíduos sólidos se agravou de forma particularmente intensa em São Paulo, com a rápida urbanização ocorrida no Brasil entre as décadas de 40 e 70: a infra-estrutura urbana física e de prestação de serviços públicos não conseguiu acompanhar o ritmo do crescimento da população urbana (OGATA 1983).

O gerenciamento dos resíduos sólidos nas áreas urbanas se basearam, historicamente, na coleta e no afastamento dos resíduos. Ao longo do tempo as administrações municipais ou locais equivalentes passaram a prestar o serviço de coleta e afastamento. Esse tipo de serviço, especialmente quando executado com eficiência, cria a sensação mágica na população de que os resíduos simplesmente desaparecem de sua vista. Por isso a sociedade em geral levou muito tempo para perceber as graves tendências relacionadas à quantidade, qualidade e às soluções para o gerenciamento dos resíduos sólidos.

A maioria dos municípios brasileiros não dispõe de infra-estrutura adequada para seu manuseio. Nos municípios que têm soluções sanitariamente corretas, em geral essas soluções se resumem a coletar os resíduos nas residências e aterrá-los 
(IBGE 1991, SMA 1998a). No Estado de São Paulo 78\% dos municípios dispõem seus resíduos no solo de forma inadequada e somente $10,9 \%$ do total de resíduos sólidos domésticos gerados são dispostos de forma adequada (SMA 1998a).

Nas regiões metropolitanas existe a tendência de se esgotarem de forma cada vez mais rápidas os espaços para aterros sanitários. Como conseqüências haverá o aumento dos custos de disposição final, seja pelo aumento das distâncias para transporte, pelos custos de novas áreas ou pela introdução de outros processos tecnológicos como a incineração.

Este é portanto um problema de saúde pública, que envolve questões de interesse coletivo, mas profundamente influenciado por interesses econômicos e por manifestações da sociedade, por aspectos culturais e por conflitos políticos.

Atualmente a visão da sociedade sobre a questão dos resíduos sólidos tem incorporado novos elementos, notando-se avanços significativos na importância que se confere a ela. Consequentemente cada vez mais espaço na mídia e nas discussões políticas é ocupado pelos problemas associados aos resíduos sólidos

Diversos autores têm apontado para soluções nas quais não só os governos, mas diversos setores da sociedade civil desempenham papéis importantes, e nas quais se aplicam diversas alternativas, e não apenas a mera disposição final dos resíduos. Os próprios governos nacionais reconheceram a necessidade de inclusão da comunidade na elaboração e no encaminhamento de problemas ambientais em geral, quando assinaram a Agenda 21 Global, durante a Conferência das Nações Unidas sobre Desenvolvimento e Meio Ambiente em 1992, no Rio de Janeiro. A evolução das experiências em alguns países, notadamente os europeus, levou à produção de legislação que reverte a responsabilidade pela destinação dos resíduos de diversos produtos para o fabricante do produto. No Brasil, se iniciam as discussões nesse sentido, com particular interesse pelas pilhas, baterias e lâmpadas usadas, e mais recentemente quanto aos pneus. Essas mudanças trouxeram, no âmbito internacional, 
muitas conseqüências para a organização, economia e operação do sistema de coleta e tratamento dos resíduos sólidos domésticos.

Além disso, nota-se que em nosso País tem havido movimentos para revalorização e melhoria da qualidade de vida das populações que retiram do lixo seu sustento, principalmente catadores, cuja organização tem sido incentivada para se integrarem no sistema organizado de coleta seletiva de lixo. Por outro lado, os sistemas de coleta seletiva pressupõem a existência de um mercado para os materiais recicláveis, o que torna imprescindível o envolvimento do setor industrial. A iniciativa privada já participa dos serviços do sistema de resíduos sólidos prestando serviços de coleta há bastante tempo, e parece haver espaço para que ela participe também de outras atividades do sistema, como a industrial.

Apesar de ser considerada recomendável a reciclagem de resíduos, a efetivação de programas institucionalizados enfrenta por vezes dificuldades importantes, que levam até mesmo à inviabilidade da sua implementação.

Diante destas questões, pergunta-se inicialmente como têm se inserido os vários setores sociais nessas novas formas de organização do gerenciamento dos resíduos sólidos domésticos. Esta pergunta pode ser desdobrada em outras que surgem como conseqüência: em que medida as iniciativas dos setores não-estatais estão contribuindo para o gerenciamento integrado dos resíduos sólidos domésticos? Como acontecem as relações entre o Estado e os setores não-estatais a respeito deste assunto? Como se desdobram os conflitos políticos e econômicos que regem essas relações? Como atuam as ONGs e as empresas privadas? Estão sendo utilizadas formas de cooperação e parcerias? Como elas funcionam? Quais são as soluções criativas que têm sido aplicadas nos programas em andamento? 


\section{CONSIDERAÇÕES FINAIS}

Os programas estudados demonstraram resultados que podem ser ainda melhorados, com conseqüências ambientais, sociais e econômicas positivas, e portanto em direção ao almejado desenvolvimento sustentável. Algumas das principais barreiras a serem vencidas são: a correta apropriação dos custos; a capacitação do pessoal; hábitos e costumes arraigados; falta de prioridade política; falta de divulgação de informações existentes.

Entre os resultados obtidos, destaca-se que a maioria dos programas ainda tem resultados relativamente discretos quanto ao volume de resíduos desviados dos aterros sanitários. Os resultados se devem tanto ao pequeno porte dos programas, quando apenas uma parte da população é atendida, quanto ao grau de adesão ainda relativamente baixo da maioria da população. A melhor taxa de desvio foi observada em Goiânia.

Durante o estudo, foram identificadas poucas iniciativas no sentido da redução da geração na fonte, o que deveria receber mais ênfase em ações futuras, a fim de cumprir recomendações de diversos documentos, inclusive a Agenda 21.

Os programas observados no presente estudo não são fechados em si, mas têm necessariamente relações com outros programas e sistemas. Foi possível demonstrar que o apoio de instituições do mercado produtivo e da sociedade civil aos programas municipais, em especial as parcerias, podem contribuir de maneira decisiva para a viabilização de tais programas, e que as políticas públicas de resíduos sólidos que vierem a ser implantadas devem estar articuladas com outras políticas, como as políticas industrial, econômica, de ciência e tecnologia, social e ambiental.

Ficou claro também que a implantação de programas de coleta seletiva e reciclagem de resíduos sólidos domésticos exige que o sistema tenha capacidade para tratar os diversos aspectos da questão, e que a participação de diversos atores sociais 
permite que se obtenha esta capacidade sem aumentar o tamanho da estrutura municipal dedicada aos resíduos sólidos, a custos ainda viáveis.

Os casos estudados mostram também que é possível a parceria públicoprivado para gerenciamento de resíduos sólidos domésticos, e se mostraram essenciais neste sentido as parcerias entre as instituições promotoras dos programas e catadores já atuantes e com a comunidade local, sem dispensar o apoio dos órgãos de financiamento, das indústrias e sucateiros da região. Por outro lado, foi identificada apenas uma atuação conjunta entre municípios, o que confirmou a dificuldade de articulação entre diferentes administrações municipais para tratar do assunto.

Nas entrevistas foram citadas diversas instituições potencialmente parceiras, e que ainda não apóiam os programas. Entre elas os órgãos da esfera federal aparecem em maior número, e as principais formas de ajuda a serem buscadas são o financiamento e a cooperação tecnológica. Para que ocorra este contato é preciso estabelecer canais de comunicação entre as pequenas instituições, como pequenas indústrias, cooperativas e prefeituras, com os órgãos de financiamento, de decisão política e mesmo com associações de empresas e de instituições. Estas, em particular poderiam ser o próprio elo de ligação. Uma postura mais participante dos pequenos empresários da reciclagem, incluídos aí comerciantes e industriais, poderia tornar as associações o próprio elo de comunicação.

O envolvimento de diversas instituições nos programas gera a necessidade de capacitação de pessoas. Trata-se tanto dos técnicos, que muitas vezes não têm formação pessoal e/ou profissional para trabalhar dentro de posturas participativas modernas, quanto da mão-de-obra pouco qualificada que trabalha na coleta, triagem e processamento dos materiais, que sempre são os trabalhadores que entram em contato com a comunidade geradora.

Do ponto de vista da comercialização dos materiais, é importante o papel dos resíduos de origem não doméstica, como o industrial e o comercial, principalmente papel/papelão e plásticos filme, na sustentação econômica das iniciativas. Também 
chama a atenção a existência de "âncoras", que são os materiais mais disponíveis ou de maior valor, que parecem sustentar as atividades e ajudam a manter a estrutura de outros materiais, permitindo geração de novas oportunidades. Por outro lado, a dificuldade de escoamento de produtos e os baixos preços obtidos pelos materiais foi geralmente citada como conjuntural, e não estrutural.

Os programas mostraram que a coleta seletiva e reciclagem dos resíduos domésticos não é um processo barato. Os custos de coleta e transporte se mostraram predominantes, dentre os quais os investimentos com veículos e sua manutenção, e com a mão-de-obra são a maior parte. E estes gastos são ainda preferencialmente bancados pelas prefeituras municipais. Embora todos os programas tenham revelado preocupação com a Educação Ambiental, em geral há um controle relativamente precário dos gastos neste setor. Com administração competente e com participação da sociedade é possível distribuir os custos, reduzindo os encargos públicos e portanto os custos com que a população arca.

Por outro lado, a maioria dos programas está associada a algum tipo de geração de emprego e renda, seja de catadores, pacientes de serviços de saúde mental ou presidiários. Os rendimentos auferidos pelos trabalhadores, mesmo em cooperativa, não excederam os $\mathrm{R} \$ 300$ mensais. Deve-se buscar, por isso, pesquisas de natureza econômica para determinar o efeito multiplicador dos investimentos nestas atividades, que pareceram em princípio bastante atrativos.

Recomenda-se para a implementação de novos programas de coleta seletiva as seguintes diretrizes:

a) Definir claramente os objetivos e a área de abrangência do programa.

b) Buscar informações sobre outros programas similares e tecnologias existentes.

c) Identificar dados sobre a geração de lixo local, o mercado de recicláveis e a ação de catadores.

d) Integrar as atividades informais existentes e o mercado de resíduos comerciais e industriais, estabelecer parcerias com indústrias locais, sucateiros e catadores. 
e) Incentivar a instalação de empresas recicladoras localmente.

f) Buscar tecnologias alternativas, especialmente para fabricação de produtos reciclados.

g) Capacitar técnicos, empresários e catadores

h) Trabalhar intensamente a Educação Ambiental, buscando o apoio da mídia, limitando-se porém à capacidade de atendimento do programa.

i) Administrar o programa como um processo de evolução e não como solução estática.

j) Prever gastos maiores no processo de implantação nas primeiras etapas.

k) Investir em controle de informações, utilizando indicadores operacionais de rendimento de mão-de-obra e equipamentos, de impacto na comunidade e no ambiente para avaliar constantemente o progresso do programa e detectar necessidade de correções.

1) Priorizar as áreas de alta densidade demográfica e os grandes geradores como condomínios.

m) Integrar na coleta seletiva as ações para segregação de resíduos perigosos e objetos de grande volume.

n) Buscar a viabilização da compostagem de resíduos orgânicos nas áreas atendidas pela coleta seletiva.

o) Integrar a coleta seletiva às ações de saúde pública no controle de vetores.

Enfim, para o sucesso dos programas de coleta seletiva e reciclagem é importante agir no sentido da inclusão de diversos parceiros, como associações de classe, instituições financeiras, organismos comerciais e entidades assistenciais, mesmo que não pareçam usuais. Tais parcerias e apoios devem estruturar os programas nos seguintes aspectos principais:

a) Disponibilização de equipamentos

b) Disponibilização de mão-de-obra

c) Capacitação da mão-de-obra para operação e gerência

d) Viabilização comercial

e) Gestão do programa 
Nesta busca desenham-se caminhos alternativos para gerenciamento de resíduos sólidos domésticos. A decisão política da administração municipal, aliada à capacitação de seus recursos humanos caracteriza-se como fundamental. As mudanças de postura dos atores não ocorrem, entretanto, de uma hora para outra. É preciso paciência e perseverança para eliminar preconceitos e conquistar a confiança dos futuros parceiros. E felizmente, há pessoas dispostas a enfrentar estes desafios e contribuir o avanço da solução da questão dos resíduos sólidos. 


\section{OBJETIVOS}

São os seguintes os objetivos estabelecidos para o trabalho, a partir das questões identificadas:

\section{a) objetivo geral:}

Estudar experiências de gerenciamento de resíduos sólidos domésticos através de parcerias, identificando pontos positivos e negativos nas relações interinstitucionais, e verificando a relação entre o indicado pela literatura e o constatado nos estudos de caso.

\section{b) objetivos específicos:}

b.1. Conhecer o histórico e o funcionamento dos programas estudados.

b.2. Identificar impactos ambientais dos programas.

b.3. Identificar e analisar dados sobre custos dos programas.

b.4. Identificar aspectos sociais envolvidos nos programas.

b.5. Identificar as principais formas de cooperação existentes nos programas.

b.6. Identificar problemas freqüentes e soluções apontadas.

Espera-se, ao cumprir tais objetivos, obter dados relevantes para instituições interessadas em implementar programas de coleta seletiva de resíduos sólidos domésticos, no sentido de subsidiar a formação de parcerias que viabilizem tais programas operacional e economicamente, com benefícios para a Saúde Pública e para o processo de Desenvolvimento Sustentável no País. 


\title{
3. CONCEITOS E FUNDAMENTAÇÃO TEÓRICA
}

\subsection{Resíduos Sólidos: definição e classificação}

\author{
Segundo a definição da ABNT - Associação Brasileira de Normas Técnicas, \\ resíduos sólidos são:
}

“... resíduos nos estados sólido e semi-sólido, que resultam de atividades da comunidade de origem: industrial, doméstica, comercial, agrícola, de serviços e de varrição. Ficam incluídos nesta definição os lodos provenientes dos sistemas de tratamento de água, aqueles gerados em equipamentos e instalações de controle de poluição, bem como determinados líquidos cujas particularidades tornem inviável o lançamento na rede pública de esgotos ou corpos de água, ou exijam para isso soluções técnica e economicamente inviáveis face à melhor tecnologia prática disponível.” (ABNT 1987; p. 1-2).

A legislação norte-americana define os resíduos sólidos como:

"... qualquer tipo de lixo, refugo, lodo de estação de tratamento de esgoto, de tratamento de água ou de equipamento de controle de poluição do ar, e outros materiais descartados, incluindo sólidos, líquidos ou semi-sólidos, ou gás conteinerizado resultantes de operações industriais, comerciais, de mineração e agrícolas, e de atividades da comunidade, porém não inclui sólidos ou materiais dissolvidos e esgoto doméstico, ou sólidos ou materiais dissolvidos na água de fluxo de retorno em irrigação, descargas pontuais Sujeitas a licenciamento sob a seção 402 do Ato Federal sobre Poluição da água, conforme emendado (86 Stat. 880), ou fonte nuclear, ou subproduto como definido pelo Ato de Energia Atômica de 1954, conforme emenda (68 Stat 923). (USA 1989; p. R-8).

Uma outra definição importante é a que consta na Agenda 21:

Os resíduos sólidos, para os efeitos do presente capítulo, compreendem todos os restos domésticos e resíduos não perigosos, tais como os resíduos comerciais e institucionais, o lixo da rua e os entulhos de construção. Em alguns países, o sistema de gestão dos resíduos sólidos também se ocupa dos resíduos humanos, tais como excrementos, cinzas de incineradores, sedimentos de fossas sépticas e 
de instalações de tratamento de esgoto. Se manifestarem características perigosas, esses resíduos devem ser tratados como resíduos perigosos. (CNUMAD 1992; p. 273)

Figura 3.1. Diagrama esquemático de algumas definições utilizadas

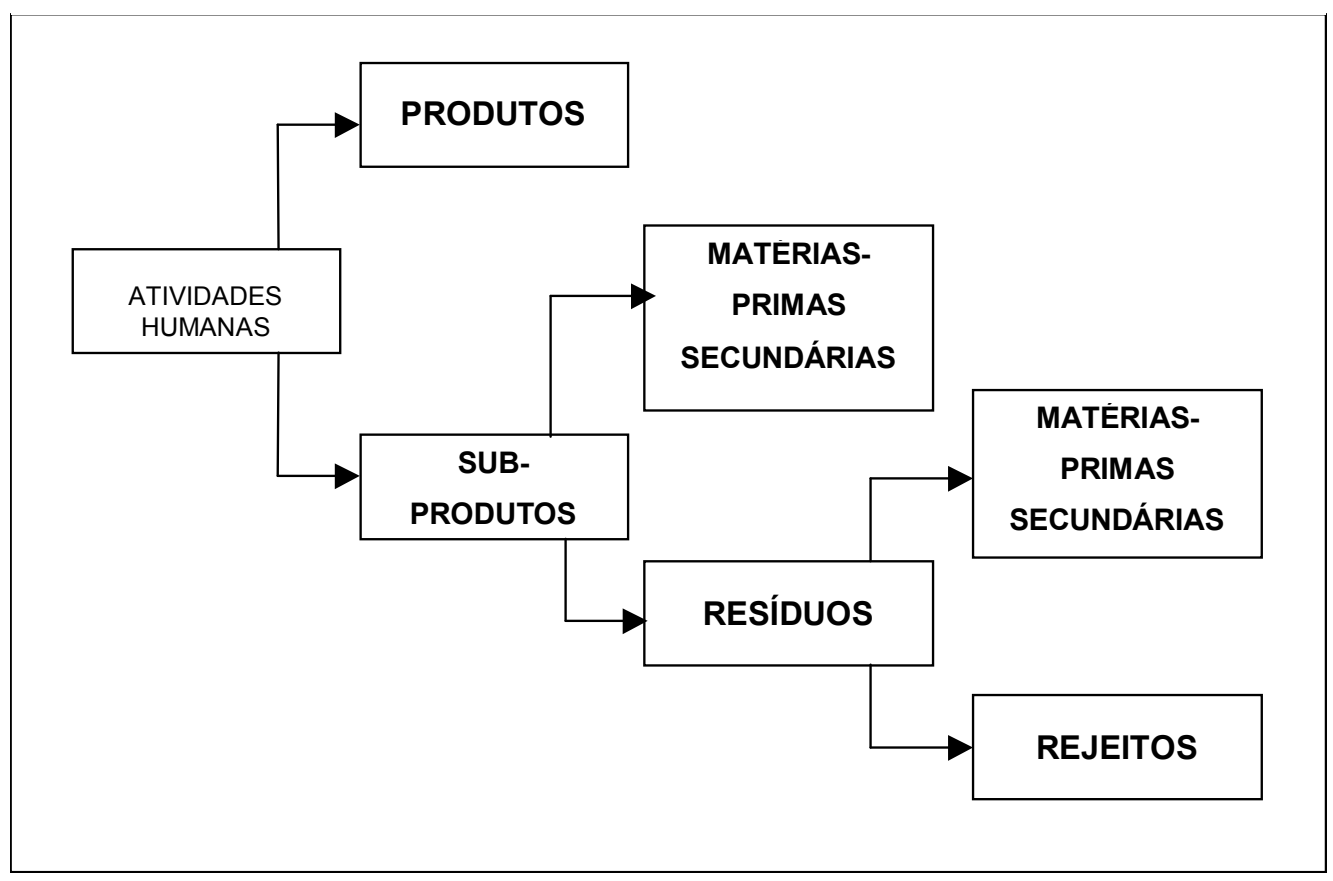

Definições alternativas incluem uma faceta econômica, ou seja, de que o resíduo é o material que não tem mais valor econômico para seu possuidor - veja-se por exemplo PHILIPPI JR. (1979). Na interpretação dos órgãos normativos europeus, o conceito tem sido de que resíduo é tudo aquilo que requeira processamento físico ou químico para reaproveitamento, mesmo que ainda conserve um valor econômico residual (TROMANS e FITZGERALD 1998). Isto é cosequência do limite ainda impreciso entre o que são sub-produtos e o que são coprodutos, podendo haver distinção não somente quanto ao processo gerador, mas também quanto ao uso que se dá.

De qualquer modo os resíduos constituem, em todas as definições, subprodutos da atividade humana com características específicas, definidas geralmente pelo processo que os gerou. Do ponto de vista da sociedade, materiais descartados 
que são aproveitados deixam de ser resíduos, constituindo-se as matérias-primas secundárias (Figura 3.1). Em particular, são denominados rejeitos todos os resíduos que não têm aproveitamento econômico por nenhum processo tecnológico disponível e acessível.

Em função das mudanças de abordagem das questões ambientais em geral e dos resíduos sólidos em particular, o conceito de resíduo sólido tem suscitado a necessidade de revisão. Observa-se que a definição da ABNT se aproxima bastante das definições internacionais apresentadas (USA 1987 e CNUMAD 1992), motivo pelo qual no presente trabalho é utilizada a definição da ABNT.

Os resíduos sólidos podem ser classificados, segundo a origem, como: industriais, de serviços de saúde, comerciais, de portos e aeroportos, de varrição, domésticos, e outros (ABNT 1987). No presente trabalho são considerados resíduos sólidos domésticos aqueles gerados nos lares. Podem incluir também, dependendo de normatização municipal, os resíduos comerciais e industriais compatíveis com os domésticos, tipicamente aqueles classificados como classe II ou classe III pela norma ABNT 10.004, quando produzidos em quantidades dentro dos limites da responsabilidade do sistema municipal. Os resíduos sólidos de origem doméstica são conhecidos também como lixo. A denominação alternativa resíduos sólidos municipais não é aqui utilizada porque incluiria outros tipos de resíduos, como o entulho de construção, não incluídos no escopo do trabalho.

\subsection{Geração de resíduos sólidos domésticos}

A geração de resíduos sólidos é inerente à atividade cotidiana do ser humano, e portanto, enquanto houver pessoas sobre a face da Terra, haverá resíduos sólidos gerados.

A quantidade de resíduos produzida por habitante e as características dos resíduos domésticos também variam em função dos hábitos de consumo da 
população - resultado de poder aquisitivo e fatores culturais - e têm tido uma evolução ao longo do tempo. Como exemplos pode-se citar a diminuição da matéria orgânica presente e aumento de materiais provenientes de embalagens descartáveis. A Tabela 3.1. mostra, a título de exemplo, a evolução da composição dos resíduos sólidos domésticos no município de São Paulo.

Tabela 3.1. Composição percentual em peso dos resíduos sólidos domésticos gerados no município de São Paulo, em vários anos.

\begin{tabular}{l|r|r|r|r|r|r}
\hline COMPONENTES & $\mathbf{1 . 9 2 7}^{\mathbf{a}}$ & $\mathbf{1 . 9 5 9}^{\mathbf{a}}$ & $\mathbf{1 . 9 6 9}^{\mathbf{a}}$ & $\mathbf{1 . 9 7 6}^{\mathbf{a}}$ & $\mathbf{1 . 9 9 1}^{\mathbf{a}}$ & $\mathbf{1 9 9 6}^{\mathbf{b}}$ \\
\hline Matéria orgânica & 82,50 & 76,00 & 52,20 & 62,70 & 60,60 & 52,2 \\
Papel/Papelão/Jornal & 13,40 & 16,70 & 29,20 & 21,40 & 13,87 & 19,2 \\
Plástico duro/Filme & - & - & 1,90 & 5,00 & 11,47 & 14,8 \\
Metal Ferroso & 1,70 & 2,23 & 7,80 & 3,90 & 2,83 & 2,6 \\
Metal não Ferroso & - & - & - & 0,10 & 0,69 & - \\
Trapos / couro / borracha & 1,50 & 2,70 & 3,80 & 2,90 & 4,39 & 5,7 \\
Vidros & 0,90 & 1,40 & 2,60 & 1,70 & 1,69 & 2,3 \\
Terra / Pedras & - & - & - & 0,70 & 0,77 & - \\
Madeira & - & - & 2,40 & 1,60 & 0,75 & 0,7 \\
Diversos & - & 0,10 & - & - & - & 2,5 \\
Perdas & - & - & - & - & 1,71 & \\
\hline Total & 100 & 100 & 100 & 100 & 100 & 100 \\
\hline Peso específico & 500 & 300 & 230 & - & 234 & - \\
\hline
\end{tabular}

Fontes: (a) SSO (1992) e (b) LEÃO e TAN (1998).

Quanto à diferença de composição dos resíduos sólidos domésticos gerados em diversos municípios, nota-se que em certas cidades maiores e mais industrializadas (São Paulo e Rio de Janeiro) o conteúdo em plásticos, por exemplo, é bem mais alto que nas outras cidades, mostrando a influência do tipo de sociedade na geração de lixo, devido às características particulares do modo de vida da população.

Tabela 3.2. Composição dos resíduos sólidos domésticos em porcentagem de peso em algumas cidades do Brasil em 1992/93

\begin{tabular}{cccccc}
\hline COMPOSIÇÃO & São Paulo & Rio de Janeiro & Salvador & Fortaleza & Campo Grande \\
\hline Orgânicos & 63 & 34 & 43 & 65 & 62 \\
Papel & 14 & 27 & 19 & 16 & 19 \\
Plástico & 13 & 13 & 11 & 8 & 6 \\
Metal & 3 & 3 & 4 & 5 & 3 \\
Vidro & 1 & 2 & 4 & 7 & - \\
Outros & 6 & 21 & 19 & - & 10 \\
\hline Total & 100 & 100 & 100 & 100 & 100 \\
\hline
\end{tabular}

Fonte: CEMPRE (1994) 
No Estado de São Paulo são gerados diariamente 18.232 toneladas de lixo domiciliar, o que resulta uma média de $0,58 \mathrm{~kg} /$ habitante (SMA 1998a). A quantidade de resíduos per capita produzida também varia, sendo que a tendência ao longo do século XX foi o aumento, sendo que em vários países desenvolvidos ela supera a marca de $1 \mathrm{~kg} / \mathrm{hab} /$ dia.

No Município de São Paulo são coletados diariamente aproximadamente 10.000 t/dia de resíduos sólidos domésticos (SVMA 1996). A esta quantidade deve ser acrescida uma quantidade coletada independentemente por catadores para recuperação de materiais, sobre a qual há poucos dados precisos, mas que apontam para quantidades da ordem de 2.500 t/dia (RUBERG e col. 1998).

\subsection{Questões ambientais e de saúde pública associadas aos resíduos sólidos}

Os resíduos sólidos domésticos podem causar impactos negativos no ambiente de diversas formas. Podem tornar o solo, as águas e o ar impróprios aos usos diversos, ou prejudiciais à saúde, causando portanto poluição. Podem ainda causar vários tipos de incômodo, como a poluição visual.

Os resíduos sólidos domésticos podem conter certos contaminantes químicos que podem prejudicar o equilíbrio ecológico e a saúde pública, tais como metais pesados e outras substâncias orgânicas tóxicas. Estes contaminantes podem ser originários de pilhas e baterias usadas, lâmpadas fluorescentes, embalagens vazias de inseticidas, solventes e tintas, e outros produtos de uso doméstico. Os resíduos sólidos domésticos contêm, além disso, frações significativas de materiais orgânicos, tais como restos de alimentos, de papéis e outros materiais sanitários. A decomposição de materiais orgânicos gera chorume, um líquido escuro, malcheiroso e altamente poluente. Além disto, os resíduos podem estar contaminados com agentes patogênicos. 
A contaminação do solo por resíduos ocorre pela disposição inadequada destes sobre aquele. A área contaminada pode deixar de ser útil para determinadas finalidades, para fins agrícolas, para construção de edificações, entre outras, dependendo do tipo de contaminação. A recuperação de tais áreas degradadas é geralmente um processo complexo, lento, dispendioso e nem sempre eficiente, pois não há processos tecnológicos conhecidos para todos os tipos de contaminação. Além disso decorrem da contaminação do solo graves prejuízos econômicos.

Figura 3.2. Vias de contato homem-resíduos sólidos e a transmissão de doenças

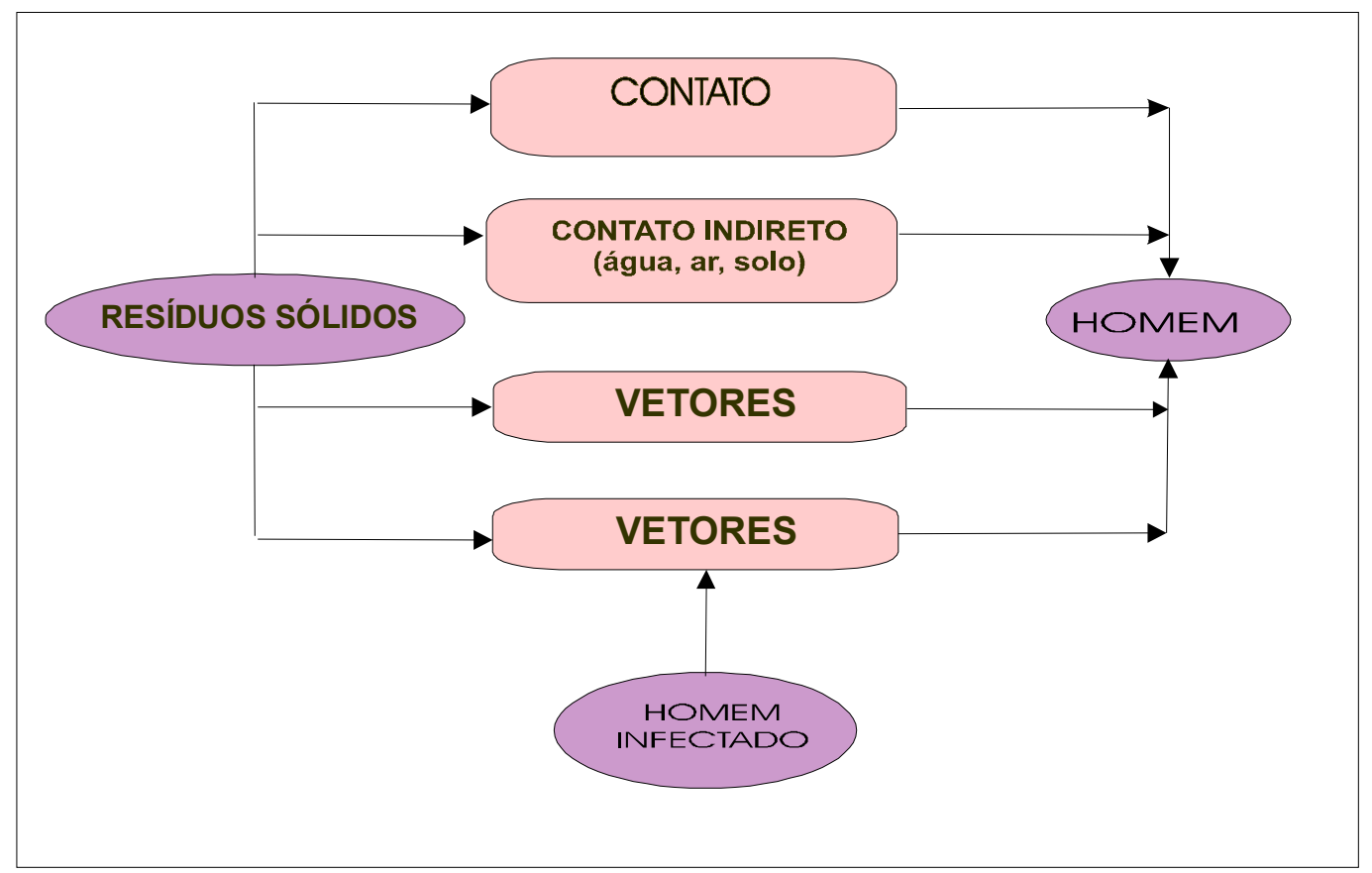

A contaminação das águas superficiais e sub-superficiais pode ocorrer por despejo direto dos resíduos na água ou por percolação de líquidos em áreas de deposição. Neste caso, o que ocorre é que o solo atua como tampão, absorvendo ou adsorvendo contaminantes em determinadas condições até ficar saturado, liberandoos de volta ao meio aquoso posteriormente. Tanto o chorume produzido no processo de decomposição da matéria orgânica quanto as águas pluviais ou de irrigação podem carregar os contaminantes do solo para o lençol freático ou para cursos 
d'água, podendo tornar tais águas inadequadas para usos diversos. Nos casos em que mananciais de abastecimento estão envolvidos, exige-se cuidados especiais.

A contaminação do ar pode se dar pelo odor proveniente dos resíduos ou pela queima inadequada dos mesmos. Tal queima pode gerar compostos mais perigosos do que aqueles presentes originalmente nos resíduos, como é o caso dos óxidos de enxofre, dioxinas e furanos.

A poluição visual ocorre quando uma quantidade de resíduos disposta inadequadamente ou que se acumula antes da coleta, se tornam bastante visíveis. Este é um dos aspectos que chama mais a atenção do público em geral. O descuido com atividades de limpeza pública em áreas urbanas e a disposição inadequada em áreas de grande circulação leva ao acúmulo de resíduos visíveis, que podem causar enormes incômodos.

O contato do homem com os agentes patogênicos presentes no lixo ou associados a ele pode ocorrer de forma direta e indireta (Figura 3.2). Quando jogados inadequadamente nas ruas e calçadas os resíduos sólidos podem causar entupimento das redes de drenagem urbana, o que leva a inundações e alagamentos nas épocas de chuva, que também aumentam o risco de transmissão de leptospirose.

Além disto os resíduos sólidos podem oferecer alimento, água e abrigo para fauna sinantrópica e por isso os resíduos sólidos domésticos são uma fonte potencial de problemas com doenças transmissíveis. O acúmulo desses resíduos em locais inadequados propicia a proliferação de vetores de doenças transmissíveis. A Tabela 3.3 mostra algumas das doenças transmitidas por vetores associados ao lixo.

Artrópodes e roedores de interesse em Saúde Pública encontram alimento em resíduos mal acondicionados e nas áreas de disposição inadequada; em embalagens vazias e sucatas onde se acumula água parada se desenvolve o mosquito transmissor da dengue. 
Tabela 3.3. Exemplos de doenças transmitidas por vetores associados aos resíduos sólidos domésticos.

\begin{tabular}{|l|l|l|}
\hline VETORES & PARASITAASSOCIADO & DOENÇAS \\
\hline Roedores & $\begin{array}{l}\text { Ricketsia akari } \\
\text { Leptospira icterohemorragiae } \\
\text { Ricketsia typhi }\end{array}$ & $\begin{array}{l}\text { Riquetsiose } \\
\text { Leptospirose } \\
\text { Tifo murino }\end{array}$ \\
\hline Moscas & Salmonella sp, Schigella sp & Diarréias diversas \\
\hline Baratas & $\begin{array}{l}\text { Salmonella Typhi } \\
\text { Schigella sp } \\
\text { Polio virus }\end{array}$ & $\begin{array}{l}\text { Febre tifóide } \\
\text { Chiguelose } \\
\text { Poliomielite }\end{array}$ \\
\hline Aedes aegipti & Vírus da dengue & Dengue \\
\hline
\end{tabular}

Adaptado de LIMA (1991.)

Por outro lado, ressalta-se que os resíduos sólidos domésticos estão associados à exaustão de recursos naturais, na medida em contêm materiais produzidos com recursos naturais, muitas vezes não renováveis. Alumínio, aço e bronze provenientes de minérios e plásticos provenientes do petróleo são bons exemplos. Restos orgânicos são geralmente originários de alimentos que para sua produção necessitaram que fossem retirados nutrientes do solo e que fosse consumidos trabalho e energia. Portanto a presença de restos orgânicos nos resíduos apontam também para formas de desperdício.

\subsection{Sistema de Limpeza Pública e Sistema de Resíduos Sólidos}

OLIVEIRA (1982; p. 84) define a limpeza pública como “o conjunto de atividades que permite o adequado estado de limpeza de uma cidade, sem prejudicar a qualidade do ambiente, inclusive na região que a circunda.”.

Entre as atividades características dos sistemas de limpeza pública pode-se destacar:

a) varrição de vias e logradouros públicos;

b) limpeza de monumentos, escadarias e outros edifícios públicos;

c) remoção de animais mortos;

d) limpeza de terrenos baldios; 
f) desobstrução de bocas de lobo;

g) capinação de vias e logradouros públicos;

h) coleta, transporte, tratamento e disposição final de resíduos sólidos.

As atividades de coleta, transporte, tratamento e disposição final de resíduos sólidos constituem o Sistema de Resíduos Sólidos, que é portanto um dos componentes do Sistema de Limpeza Pública.

\subsection{Os setores da sociedade e os seus papéis}

A divisão da sociedade em três setores - Estado, Mercado e Terceiro Setor utilizada por diversos autores (por exemplo LANDIM 1993), é também aplicada neste trabalho. Os agentes envolvidos nos programas de coleta seletiva serão classificados como:

a) estatais: órgãos do Estado e a eles ligados direta ou indiretamente;

b) privados: pertencentes ao mercado, produzindo e comercializando bens e serviços, que atuam com objetivo de lucro;

c) terceiro setor: sem fins lucrativos, como associações e demais organizações não governamentais.

Cada um dos setores e grupos tem interesses próprios - econômicos, políticos, entre outros - que conduzem sua ação em relação aos resíduos. Portanto o conhecimento dos anseios e obrigações individuais de cada setor e suas relações poderia permitir que se estabeleçam ações na direção do gerenciamento integrado. Esta necessidade se intensifica na medida em que se reconhece cada vez mais a importância da participação da comunidade - consumidores, empresas, ONG's nesse processo. Este ponto é fundamental para a definição das categorias de análise a serem definidas e trabalhadas na parte dos procedimentos metodológicos. 


\subsubsection{O Estado}

A responsabilidade pela solução dos resíduos domésticos recai sobre as prefeituras por força da legislação atual. A Constituição Federal estabelece em seu artigo 30 que "compete aos municípios (....) organizar e prestar, diretamente ou sob regime de concessão ou permissão, os serviços públicos de interesse local (....)" (BRASIL 1988). A Lei Orgânica do Município de São Paulo, por exemplo, estabelece que a administração da coleta, do tratamento e do destino do lixo é serviço público municipal (SÃO PAULO (cidade), Lei Orgânica do Município, de 4/4/90, cit. por CALDERONI 1998, p.50).

O sistema de resíduos sólidos é serviço público essencial. É tarefa do Município gerenciá-lo, o que significou historicamente não só regular o sistema e promover ações, mas principalmente executar os serviços. Entretanto, na maioria das cidades, a coleta e destinação dos resíduos sólidos em geral se manifesta historicamente como um serviço público dos menos desenvolvidos (GARCEZ FILHO 1965). A prioridade quase sempre foi dada à coleta e afastamento dos resíduos. Somente a partir da década de 70 a destinação final através de aterros sanitários também teve destaque (OGATA 1983).

As ações do poder público no sentido de reduzir o volume de resíduos sólidos domésticos gerados e de incentivar a reciclagem dos materiais presentes nos resíduos têm sido isoladas. Não há Políticas de Resíduos Sólidos formalizadas em nível nacional ou estadual, apesar de que já há projetos em trâmite (SMA 1998b, 1998c). Existem apenas projetos de lei nesse sentido em nível nacional, e minutas em discussão em nível estadual. O problema dos resíduos sólidos é tratado genérica e superficialmente em documentos oficiais que tratam de saneamento básico e que enfatizam o abastecimento de água e o afastamento e tratamento de esgotos sanitários.

Alguns fatores têm contribuído recentemente para mudança desse contexto e da visão do papel do Estado. Um deles, de ordem mais geral, é a intensificação do 
debate das questões ambientais, em nível internacional, que teve seus reflexos no Brasil na segunda metade da década de 70 e na primeira metade da década de 80 . Já na segunda metade desta década há registros de iniciativas de coleta seletiva por parte de ONGs e prefeituras. Outro fator é o lançamento da Agenda 21 Global pela Conferência das Nações Unidas sobe Desenvolvimento e Meio Ambiente, em 1992, que estabeleceu diversas diretrizes a respeito de resíduos sólidos e recomendou em vários pontos a participação da sociedade na solução dos problemas.

Adicionalmente há o processo de privatização dos serviços públicos, e os serviços de resíduos sólidos já contam com participação da iniciativa privada em diversos municípios. ACURIO e col. (1997) lembram que nas maiores cidades a atratividade econômica da prestação de serviços de limpeza pública é maior; nas cidades pequenas e médias e mesmo comunidades afastadas de cidades grandes é preciso encontrar outras soluções, sendo as cooperativas e as pequenas empresas familiares possibilidades a serem estudadas.

De qualquer modo, há uma mudança no papel do Estado, que deixa de operar os serviços, para se ocupar em garantir que eles sejam oferecidos à população satisfazendo as necessidades sanitárias e ambientais, ao menor custo possível.

Tudo isto tem resultado na existência de inúmeras experiências locais que aplicam novos modelos em resíduos sólidos domésticos, tanto por iniciativa das prefeituras, como por iniciativas independentes da sociedade civil organizada.

A partir da segunda metade da década de 80 iniciam-se projetos de coleta seletiva, através de prefeituras ou outras organizações. É nesta época que as organizações não governamentais no Brasil começam a incorporar também a questão urbana ao seu discurso, e com ela o assunto resíduos sólidos passa a ser tratado com maior intensidade. Eventualmente surgem iniciativas totalmente independentes da ação da prefeitura, de sorte que de alguma forma o setor não estatal acaba por substituir o Estado na função da gestão dos resíduos sólidos. Os maiores exemplos 
são a coleta via catadores, principalmente alumínio e papel, e outros setores independentes.

A maioria dos municípios têm dificuldades com o custeio dos sistemas de resíduos sólidos: inadimplência, taxas cobradas baixas demais, desconhecimento dos custos reais e pressões políticas (ACURIO e col. 1997). Isso tem imposto barreiras importantes à adoção de soluções integradas e ambientalmente mais avançadas nos sistemas de resíduos sólidos, tais como a coleta seletiva e a reciclagem de materiais.

\subsubsection{O setor de produção}

A participação dos setores privados no gerenciamento de resíduos sólidos pode ser classificada nas seguintes modalidades: operação municipal contratada sob controle e supervisão, com pagamento por serviços prestados; operação privada por concessão ou franquia; operação comunitária e microempresas; operação de mercado livre; operação mista.

Alguns autores, como ACURIO e col. (1997) classificam ainda a empresa autônoma municipal, de capital misto, como uma modalidade adicional. Quando esta modalidade foi criada, imaginava-se que ela teria a agilidade administrativa característica do setor privado e estaria livre de influências externas, o que atualmente não é uma realidade.

LEAL (1997) considera que existem quatro formas de envolver a iniciativa privada na coleta e destinação de resíduos: contratação, contrato de concessão, franquia e competição aberta.

Nos países desenvolvidos somente os dois primeiros têm tido aplicação geral. Os contratos de concessão têm o potencial de fomentar investimentos privados. As franquias parecem ter aplicação só em países em vias de desenvolvimento: o governo entrega um monopólio limitado a uma empresa privada, reduzindo riscos comerciais associados a fase inicial do negócio. 
Já há alguns anos a iniciativa privada vem sendo contratada para operar sistemas de coleta de resíduos sólidos nas grandes cidades brasileiras. Este movimento vem se intensificando, e tem sido estendido também à operação de aterros sanitários, usinas de triagem e demais equipamentos pertencentes ao sistema de resíduos sólidos.

Os programas de coleta seletiva e reciclagem de resíduos pressupõem a existência da atividade de industrialização dos materiais, eminentemente privada, realizada no ambiente de mercado por empresas com finalidade de lucro. Esta atividade envolve geralmente uma cadeia de sucateiros, ou seja, aqueles que coletam pequenas quantidades vendem o material a sucateiros que dispõem de mais recursos, os quais vendem o material para os beneficiadores e indústrias recicladoras.

\subsubsection{O terceiro setor}

O terceiro setor não tem muita tradição de participar do gerenciamento dos resíduos sólidos domésticos, mas nos últimos dez anos tem havido iniciativas importantes. Vários dos programas de coleta seletiva e reciclagem registrados em bibliografia científica e no noticiário jornalístico ocorrem em condomínios. Projetos de Educação Ambiental executados por Organizações não-governamentais abordam com freqüência a questão dos resíduos sólidos. A própria Organização Mundial dos Consumidores reconheceu recentemente que tem um papel a cumprir na promoção da mudança dos padrões de consumo, e destaca entre outros aspectos a necessidade de redução de geração de resíduos sólidos (HURTADO 1997).

FISCHER (1993) propõe classificar as instituições do terceiro setor existentes nos países em desenvolvimento naquelas com finalidade de receita e naquelas sem fins lucrativos. Teriam finalidade de receitas as cooperativas e as pré-cooperativas. Sem fins lucrativos as associações de desenvolvimento local, como associações de moradores de bairros; as associações de interesses, como sindicatos e associações de 
consumidores; e as organizações filantrópicas, como as fundações e entidades assistenciais.

Pelas características de organização local que apresentam as cooperativas, elas serão classificadas como terceiro setor, conforme adota FISCHER (1993), apesar de que objetivam obter receita suficiente para sustentar.

Muitas vezes o terceiro setor atua de modo a substituir o Estado em serviços públicos (LANDIM 1993). Outra possibilidade de atuação importante é a cobrançad de ações dos órgãos públicos.

\subsection{Educação Ambiental}

Há várias definições possíveis de Educação Ambiental. Por exemplo, conforme definida durante a I Conferência Intergovernamental Sobre Educação Ambiental, corresponde a uma dimensão dada ao conteúdo e à prática da Educação, orientada para a resolução dos problemas concretos do meio ambiente através de enfoques interdisciplinares e de uma participação ativa e responsável de cada indivíduo e da coletividade (DIAS 1994).

No presente trabalho, adota-se a definição estabelecida na Lei $\mathrm{n}^{\circ} 9.795$ de 27 de abril de 1999:

"Art. $1^{\circ}$ Entendem-se por educação ambiental os processos por meio dos quais o indivíduo e a coletividade constróem valores sociais, conhecimentos, habilidades, atitudes e competências voltadas para a conservação do meio ambiente, bem de uso comum do povo, essencial à sadia qualidade de vida e sua sustentabilidade."

Tem sido ressaltado que a Educação Ambiental incorpora também as dimensões socioeconômica, política, cultural e histórica, adaptando-se à realidade local e superando a visão exclusivamente ecológica-biológica do ambiente. 
Cabe ressaltar que, por um lado, a coleta seletiva é um dos instrumentos preferidos das escolas para implantação de atividades de Educação Ambiental. Por outro, a Educação Ambiental é considerada um instrumento fundamental para obtenção da mudança de comportamento e para adesão da população aos programas de coleta seletiva de resíduos sólidos domésticos. Por isso cada um dos atores envolvidos nos programas de coleta seletiva e reciclagem - comunidade atendida, garis, cooperados, técnicos, governantes, empresários - precisa passar pelo processo de Educação Ambiental.

\subsection{Parcerias}

O conceito de parceria varia bastante conforme o autor. É utilizado neste trabalho conceito como definido pelo Centro das Nações Unidas para Assentamentos Humanos, citado por WARAH (1997 p. 1):

“... o mecanismo para assegurar que as vantagens comparativas de diferentes atores no processo de desenvolvimento são exploradas numa forma de apoio mútuo, isto é, que as forças de fraquezas dos setores público, comercial, privado e não governamental são harmonizadas de modo que as forças são utilizadas ao máximo, enquanto é minimizado o potencial de ineficiência causado pelas fraquezas..."

As parcerias podem ser classificadas de diversas formas, entre elas pela natureza dos parceiros, podendo ser parcerias público-público, público-privado e privado-privado.

Os papéis assumidos pelo Estado que antes eram de regulação, promoção e operação do Sistema de Resíduos sólidos passam a se concentrar principalmente na regulação e promoção, abrindo algum espaço na promoção e principalmente na operação do sistema de resíduos sólidos para os setores não estatais. Esta mudança de papel abre portas para atuação conjunta de diversos setores e atores. Esta atuação 
conjunta, cujos laços podem ser políticos, comerciais ou operacionais podem ser consubstanciadas em parcerias.

\subsection{Desenvolvimento Sustentável e Agenda 21}

Como resultado da intensificação das preocupações com as questões ambientais que vinha ocorrendo desde a década de 60 e dos estudos das relações entre aspectos ambientais, sociais e econômicos, foi definido o desenvolvimento sustentável como aquele que permite satisfazer as necessidades da geração atual permitindo também às gerações futuras satisfazer suas próprias necessidades (CMMAD 1991).

É importante notar que as visões dos atores sociais quanto ao papel de cada um no processo de desenvolvimento sustentável é bastante diversificada, variando inclusive com sua formação profissional básica. Ao mesmo tempo em que há concordância quanto aos objetivos, há divergências quanto aos meios para se atingir a sustentabilidade. VIOLA E LEIS (1995) dividem as diferentes visões, para fins de análise, em estatista, comunitária e mercadológica. $\mathrm{Na}$ visão estatista, o desenvolvimento sustentável está associado, através da qualidade ambiental, à ação reguladora, fiscalizadora e promotora do Estado. Os autores destacam ainda que a visão comunitária não vê no Estado e no mercado eficientes alocadores de recursos, valorizando o papel das organizações de base da sociedade para desempenhar o papel mais importante no processo. O enfoque de mercado critica severamente os mecanismos regulatórios do Estado e legitima a apropriação privada dos bens ambientais, diferentemente dos outros dois enfoques.

O conceito de desenvolvimento sustentável foi uma das bases mais importantes na elaboração da Agenda 21 Global, documento produzido na Conferência das Nações Unidas sobre Meio Ambiente e Desenvolvimento, no Rio de Janeiro, em 1992. 
O capítulo 21 da Agenda 21 "Manejo ambientalmente saudável dos resíduos sólidos e questões relacionadas com os esgotos" trata mais especificamente das questões de resíduos sólidos, especialmente os resíduos domésticos. Estabelece metas quantitativas e prazos para a destinação adequada de resíduos sólidos e esgotos sanitários. Estabelece entre outras diretrizes a prioridade para minimização dos resíduos, reciclagem, tratamento e destino ambientalmente saudáveis e ampliação do alcance dos serviços referentes a resíduos (CNUMAD 1992).

Outros capítulos estabelecem também relações entre os resíduos sólidos e outros temas ambientais, econômicos e sociais, por exemplo o Capítulo 4 (Padrões Sustentáveis de Consumo), que trata da mudança dos hábitos que levam à geração exagerada de resíduos. Outro ponto importante ligado aos padrões de consumo é a erradicação da pobreza. Atingir tal objetivo implica que uma imensa parcela da população mundial que hoje é excluída socialmente deve passar a ter acesso aos bens do mercado no futuro. Esta população tende a se espelhar nos hábitos da população dos países desenvolvidos, nos quais os estilos de vida levam hoje aos padrões de consumo mais elevados de energia, água e outros recursos naturais, e à geração de mais altos índices de resíduos por habitante. Além disso os países desenvolvidos precisam vender seus produtos, e encontram nos países em desenvolvimento mercados importantes. Isto coloca em evidência o risco da insustentabilidade do desenvolvimento, se mantidos os atuais estilos de vida e padrões de consumo.

A Associação Mundial dos Consumidores, que é a organização mundial de defesa dos direitos dos consumidores mais expressiva, chama para si também uma parcela da responsabilidade das ações na direção dos padrões sustentáveis de consumo, notadamente em ações de educação ambiental e de divulgação de informações ambientais sobre produtos (HURTADO 1997).

Cada vez mais se faz necessário reduzir o volume de resíduos gerados, e não só cuidar de sua destinação adequada. Faz-se necessário questionar os valores e comportamentos que orientam os consumidores atualmente e contribuem para o agravamento desta situação. 
A Agenda 21 Global também estabeleceu que os governos locais devem consultar a população e produzir por meio de consenso suas próprias Agenda 21 Locais. Isto implica necessariamente numa forma de gestão participativa, o que contribui para introduzir novos papéis na relação entre Estado e sociedade.

Este quadro reforça ainda mais o fato de que as parcerias tendem a estar presentes no enfrentamento da questão dos resíduos sólidos, contribuindo para a implementação de soluções ambiental, sanitária e economicamente satisfatórias. 


\section{MÉTODOS E TÉCNICAS}

Os cientistas não lidam com a verdade, eles lidam com descrições da realidade limitadas e aproximadas.

(F. Capra)

Neste capítulo será apresentado o caminho percorrido para se chegar ao modelo de análise proposto, e aos instrumentos de pesquisa planejados e aos fatores e variáveis intervenientes.

\subsection{Atividades prévias}

Nas etapas iniciais as atividades de levantamento bibliográfico acompanharam as disciplinas cursadas e a elaboração do projeto para solicitação de bolsa de estudos. Em seguida essa atividade foi orientada para o detalhamento do projeto de pesquisa apresentado na qualificação, e mais tarde foi orientada para a atualização e discussão. Foram utilizadas as bibliotecas da Faculdade de Saúde Pública da USP, da Secretaria Municipal do Verde e do Meio Ambiente, da CETESB - Companhia Estadual de Tecnologia de Saneamento Ambiental, do CEMPRE Compromisso Empresarial Para Reciclagem e as bibliotecas particulares do Prof. Dr. Arlindo Philippi Jr. e do autor. Foram também utilizadas informações localizadas na INTERNET.

Uma pequena pesquisa piloto desenvolvida ao longo da disciplina HSA 5720 - Resíduos Sólidos e Limpeza Pública a respeito de programas de reciclagem de plástico permitiu experimentar formas de abordagem dos atores sociais, questões a serem formuladas e formas de registro dos resultados. Neste trabalho foram entrevistados representantes de instituições ligadas a ações de reciclagem de plásticos provenientes de resíduos sólidos domésticos, entre elas indústrias, ONGs, prefeituras e escolas. 
Em 1998 foram obtidas novas referências bibliográficas, entre elas as propostas de Políticas de Resíduos Sólidos em elaboração nas instituições envolvidas. Visitas técnicas e estágios permitiram uma compreensão mais apurada dos problemas e levantamento prévio de alguns dados, além da identificação de possíveis programas a serem estudados mais profundamente. A participação em eventos técnico-científicos na área foi decisiva nesse aspecto.

\subsection{Modelo de análise}

A análise das parcerias parte do fato de que os programas de gerenciamento de resíduos sólidos domésticos podem ser vistos como uma teia complexa de atores sociais interagindo e trocando entre si materiais e valores econômicos. Havendo indústrias que comprem materiais recicláveis, há também os sucateiros que compram os materiais de outros sucateiros ou de catadores ou dos órgãos municipais, os quais obtêm os materiais coletando resíduos recicláveis gerados pela comunidade. Tudo isso envolvendo aporte de equipamentos, tecnologia e os necessários fundos para financiamento. As entidades, órgãos públicos, associações, cooperativas e outras, que interagem nesse sistema, serão referidas daqui por diante simplesmente por instituições. Por outro lado, fatores externos como condições de mercado, financiamentos de outros órgãos e legislação trazem a influência de instituições que não estão diretamente ligadas, mas cuja contribuição pode ser fundamental. As relações de conflito e cooperação podem mostrar pontos fortes e fracos das formas de organização adotadas .

O modelo de análise a ser aplicado neste trabalho foi desenvolvido com base no uso de dimensões e categorias de análise. As dimensões de análise que permearão o trabalho são decorrentes de características das questões associadas aos resíduos sólidos domésticos e dos diversos aspectos envolvidos na solução dessas questões. São elas: 
a) Dimensão operacional: refere-se aos métodos e às tecnologias e equipamentos utilizados para coletar, triar e valorizar os resíduos até o momento da venda. Envolve as quantidades de resíduos coletadas e efetivamente recicladas e os indicadores de eficiência de utilização da mão-de-obra e dos equipamentos. É importante para identificar as dificuldades práticas encontradas na operação em cada modelo, as soluções adotadas e o envolvimento de cada instituição neste tipo de atividade.

b) Dimensão econômica: cada instituição em particular envolvida nos programas e a sociedade como um todo podem ter gastos ou auferir receitas em função do funcionamento dos programas. Cabe saber se os programas são auto-sustentáveis ou se são necessários subsídios, verbas orçamentárias públicas ou se há lucro dos diversos atores sociais na atividade. Nesta dimensão são identificados portanto as fontes dos recursos aplicados nos programas e a destinação das receitas geradas; eventualmente quanto a sociedade está pagando para que seja dado um destino aos resíduos.

c) Dimensão político-institucional: trata-se da definição das responsabilidades de cada instituição que participa do programa e do papel daquelas envolvidas de modo menos direto. Trata-se de saber sobre a iniciativa do programa, como o programa se organiza como um todo, como são articuladas as ações entre as instituições, como elas colaboram entre si e como são tomadas as decisões, qual é o envolvimento da comunidade. Aborda os apoios mútuos e os conflitos de interesses existentes.

d) Dimensão sócio-ambiental: por um lado há o impacto ambiental dos programas de coleta seletiva, avaliado por meio das quantidades de resíduos coletadas separadamente e reaproveitadas em relação ao total de resíduos coletados. Por outro lado há as condições sanitárias da manipulação dos resíduos e as medidas preventivas em relação à proliferação de vetores associados aos resíduos sólidos. Também serão incluídos alguns aspectos sociais dos programas, como Educação 
Ambiental, adesão da população e integração de cidadãos com características específicas.

Estas dimensões estão intimamente ligadas e se influenciam mutuamente. Questões de articulação inter-institucional podem viabilizar ou anular esforços operacionais, os quais são decisivos para a composição dos custos. E as condições econômicas são fundamentais para a continuidade da participação das instituições e portanto para a continuidade do programa. Somente havendo condições operacionais, econômicas e institucionais serão garantidos os resultados ambientais, sociais e sanitários almejados.

Tais dimensões não devem ser consideradas abordagens disciplinares estanques, mas como ênfases necessárias à análise das questões envolvidas no âmbito do desenvolvimento sustentável. As dimensões estão inter-relacionadas e transcendem as fronteiras disciplinares. Os programas a serem estudados são sistemas, e como tal sua compreensão não pode ser reduzida à compreensão de suas partes componentes isoladas, mas sim de suas relações e de integração (CAPRA 1985).

Outro aspecto relevante é que não existe isolamento absoluto entre o pesquisador e o objeto de pesquisa, pois a própria presença do pesquisador nos diversos ambientes dos programas, interagindo com as pessoas e fazendo perguntas, pode influenciar o seu comportamento e as respostas. Na elaboração do roteiro de entrevista e na definição dos métodos de abordagem dos entrevistados houve a preocupação de levar em conta esse fato e minimizar os desvios sempre que possível.

\subsection{Seleção dos programas a analisar}

Observou-se, nas atividades preliminares, que muitos dos programas de gerenciamento de resíduos sólidos que buscam o envolvimento da sociedade tem tido como base a coleta seletiva e a reciclagem de resíduos, sendo então as iniciativas 
desse tipo escolhidas como foco para o presente trabalho. Dentre os programas identificados por meio de referências bibliográficas e de contatos profissionais, foram selecionados cinco. Os critérios de escolha foram a acessibilidade e possibilidade de realização do trabalho de campo com os recursos financeiros disponíveis, o impacto que tais programas têm causado entre os profissionais da área de resíduos sólidos e a possibilidade de se observar modelos de articulação interinstitucional diferenciados. Todos esses fatores levaram à escolha dos seguintes programas:

a) Coleta seletiva de lixo de Embu (SP);

b) Projeto Meia Ponte, no município de Goiânia (GO);

c) Programa de coleta seletiva em Campinas (SP);

d) Programa de coleta seletiva em Santos (SP);

e) Programas de coleta seletiva na UNESP - Universidade Estadual Paulista, campus Botucatu (SP).

\subsection{Programação das entrevistas e visitas técnicas}

Os trabalhos de campo se desenvolveram por meio de entrevistas com representantes de entidades que participavam de programas de gerenciamento de resíduos sólidos doméstico. Foram selecionados representantes com autonomia administrativa e competência técnica para responder às questões propostas. Admitiuse a resposta por mais de uma pessoa, quando as informações necessárias não se concentravam num único representante.

Com base nas informações prévias obtidas sobre cada programa, foram estabelecidos contatos com entidades que em princípio desempenhariam papel-chave nos programas selecionados, a saber:

a) do Projeto Meia Ponte, de Goiânia: Instituto Dom Fernando;

b) de Embu: Prefeitura Municipal de Embu - Secretaria de Meio Ambiente; 
c) de Campinas: Prefeitura Municipal - Departamento de Limpeza Urbana;

d) de Botucatu: Departamento de Ciências Ambientais da Faculdade de Ciências Agronômicas da UNESP;

e) de Santos: Departamento de Meio Ambiente da Secretaria de Desenvolvimento Urbano e Ambiental.

A partir das entrevistas iniciais foi possível identificar as outras instituições e profissionais a serem contatados. Foi estabelecido o limite mínimo de três e o máximo de seis entrevistas por programa. Um número maior poderia tornar o trabalho mais longo e economicamente inviável, ao mesmo tempo que com um número menor de entrevistados poderia não haver informações ricas o suficiente para cumprir os objetivos propostos.

\subsection{Atividades de campo}

Em todas as instituições que realizavam a manipulação física dos resíduos foi feita uma visita técnica com o objetivo de conhecer mais de perto as atividades, identificando novos detalhes e verificando a condições de operação, tais como estado de conservação dos equipamentos, aspectos sanitários, odor, quantidades de resíduos armazenados e outros. Em alguns locais foi possível acompanhar diretamente atividades de coleta, pesagem e processamento dos resíduos. Sempre que possível foram tiradas fotografias, algumas das quais se apresentam nas descrições dos estudos de caso. Além disso, em alguns casos foram realizadas visitas técnicas sem entrevistas, em especial quando não foi localizada pessoa responsável com informações suficientes, ou quando o limite de entrevistas já havia sido superado.

Para as entrevistas foi criado um Roteiro de Entrevistas (Anexo 1), e as respostas foram anotadas pelo pesquisador. Houve a opção de não gravar as entrevistas porque, em atividades prévias, houve resistência de alguns entrevistados, especialmente de órgãos públicos. Concluiu-se que, neste caso, a utilização desse recurso poderia introduzir distorções nas respostas. 
O roteiro de entrevistas contém perguntas abertas e fechadas. Para todas elas foram solicitadas explicações e justificativas das respostas, com os objetivos de buscar elementos para estabelecimento de relações de causa e efeito, e de enriquecer a análise com a percepção dos entrevistados quanto a determinados aspectos. Houve, entretanto, a preocupação de não utilizar análise de discurso ao se trabalhar os dados coletados.

As seções em que se divide o roteiro são as seguintes:

a) Seção inicial: Dados gerais da instituição e identificação dos representantes entrevistados.

b) Seção A. Mobilização e impressões gerais: sobre os motivos da participação da instituição no programa, as dificuldades, as soluções imaginadas e o futuro da participação.

c) Seção B. Relações Inter-institucionais: sobre a relação com outras instituições participantes do programa. Identificação nominal de instituições, descrição da relação existente.

d) Seção C. Descrição Operacional: detalhes sobre as quantidades e tipos de resíduos processados, para possibilitar calcular os indicadores e outros dados quantitativos.

e) Seção D: Aspectos Econômicos: detalhes sobre custos e valores envolvidos nos programas, para possibilitar calcular indicadores e outros dados quantitativos. Úteis para avaliar as relações comerciais e as relações com órgãos públicos financiadores.

f) Seção E: Aspectos Ambientais e de Saúde Pública. Identificação dos procedimentos para controle de artrópodes e roedores e de outros riscos envolvidos nas instalações, equipamentos e edificações envolvidas no manuseio de resíduos sólidos.

Nos casos em que os dados não estavam disponíveis no momento da entrevista, foi solicitado que os dados fossem enviados posteriormente. 
Foram utilizados dados numéricos com relação a quantidades de resíduos e materiais reciclados em 1997 e 1998, conforme a disponibilidade dos dados nos registros das instituições. Os valores foram convertidos para dólares americanos, considerados neste trabalho a moeda estável para comparação. A conversão foi feita pelo valor do dólar comercial de venda médio do mês a que se referem os dados fornecidos em cada estudo de caso ou referência bibliográfica. Todos os dados econômicos utilizados são anteriores à desvalorização da moeda brasileira ocorrida na crise cambial de 1999.

\subsection{Análise dos resultados}

Após execução das entrevistas, foram analisados os diversos aspectos dos programas, utilizando-se indicadores quantitativos e qualitativos. Convém observar que alguns dos programas estudados encontram-se descritos em publicações da área. Nos casos em que houve diferenças entre os dados apresentados na entrevista e os publicados, foram utilizados os dados coletados nas entrevistas, com base no fato de estarem mais atualizados e por terem sido fornecidos sob o enfoque específico da pesquisa.

\subsubsection{Dimensão operacional}

Os indicadores calculados a partir dos dados coletados foram:

a) Quantidade de resíduos coletada (t/mês)

b) Eficiência de mão-de-obra de coleta (t/pessoa . h)

c) Eficiência de mão-de-obra de triagem (t/pessoa . h)

d) Eficiência de transporte (t/veículo . h).

Outros dados como a qualidade exigida pelos compradores e distância entre os mesmos e as centrais de triagem, quando citados pelos entrevistados como dificuldades adicionais, foram especialmente considerados. 


\subsubsection{Dimensão econômica}

Os indicadores utilizados para avaliação dos aspectos econômicos foram:

a) custos unitários de coleta e triagem $(\mathrm{R} \$ / \mathrm{t})$;

b) porcentagem da receita proveniente de cada material vendido;

c) preço dos materiais vendidos;

d) percepção sobre a viabilidade econômica da atividade;

e) investimentos realizados para implantação da coleta e reciclagem;

Os valores que foram obtidos em dólar foram convertidos para real pela cotação de R\$ 1,21/US\$ (PLANETA DINHEIRO 1999), valor aproximado registrado antes da crise cambial de 1999.

\subsubsection{Dimensão político-institucional}

Os indicadores utilizados para análise nesta dimensão são:
a) iniciativa do programa;
b) responsabilidade e contribuição de cada instituição nas parcerias;
c) percepção das entidades quanto a sua participação e dos parceiros;
d) percepção das entidades quanto a parceiros potenciais;
e) visão de futuro.

\subsubsection{Dimensão Sócio-Ambiental}

A partir dos dados coletados foram determinados os valores e/ou características dos seguintes indicadores:

a) composição percentual de materiais recicláveis vendidos nos programas

b) taxa de desvio; 
c) taxa de recuperação;

d) coleta de resíduos per capita.

e) presença de artrópodes e roedores de interesse em saúde pública e medidas preventivas tomadas para evitar a proliferação. 


\section{ASPECTOS TÉCNICOS E ECONÔMICOS DO GERENCIAMENTO DE RESÍDUOS SÓLIDOS}

O gerenciamento de resíduos sólidos domésticos envolve uma série de equipamentos e técnicas. Existem diversas alternativas tecnológicas disponíveis, cada qual com suas vantagens e desvantagens entre aspectos operacionais, ambientais, de saúde pública e de custos.

Neste capítulo são descritos sucintamente os aspectos técnicos e econômicos mais relevantes, com destaque para aqueles intimamente ligados à questão da coleta seletiva e da reciclagem de resíduos sólidos domésticos. Buscando maior comodidade e fluidez na leitura do texto, a maioria das fórmulas para cálculo de indicadores consta apenas no Anexo 2. Foram mantidas no texto apenas aquelas que mereceram comentários específicos.

\subsection{Sistemas de resíduos sólidos: aspectos técnicos}

Os sistemas de resíduos sólidos constituem conjunto ordenados de estruturas e serviços cujo objetivo é solucionar o manejo e a destinação de resíduos de forma sanitária e ambientalmente segura e economicamente viável. As atividades básicas do sistema são a coleta, o acondicionamento, o transporte, o tratamento e a disposição final dos resíduos sólidos (OLIVEIRA 1982).

\subsubsection{Acondicionamento}

O acondicionamento correto é importante porque contribui para evitar a proliferação de vetores, problemas com odores e com a estética e o bem-estar (OLIVEIRA 1982). É efetuado pela própria população servida, e é por isso a etapa do gerenciamento em que os geradores participam mais diretamente. 
A forma de acondicionamento deve obedecer normas específicas, tais como tipo de embalagem, horário de colocação na calçada e quantidade máxima de volume, dependendo da regulamentação municipal. Deve também ser estabelecida de modo a facilitar a coleta e o transporte. Nos locais onde não é possível o acesso dos veículos de coleta, devem ser instaladas lixeiras coletivas em pontos estratégicos, onde o veículo possa chegar, e a população deve levar o lixo até estes locais.

\subsubsection{Coleta}

A coleta é o componente do sistema de resíduos sólidos mais sensível aos olhos da população, e por isso mais passível de críticas (OLIVEIRA 1982). Falhas no serviço de coleta levam ao acúmulo de resíduos, propiciando a proliferação de maus odores e de vetores, além de incômodos como a poluição visual e o mau cheiro.

A coleta pode ser feita de forma unificada ou com segregação de materiais. A coleta unificada tem a vantagem de ser mais barata, e a coleta com segregação facilita o reaproveitamento de materiais e os processos de tratamento que venham a ser aplicados.

A freqüência da coleta deve ser definida em função do custo e do acúmulo de resíduos. Quanto maior a freqüência, maior o custo, porém quanto menor a freqüência, maior o acúmulo de resíduos nos domicílios.

$\mathrm{O}$ ponto de coleta (calçada ou interior da casa), horário, roteiro e equipamento são parâmetros importantes a serem definidos nas etapas de planejamento.

A coleta com segregação de materiais ou seletiva, como costuma ser chamada, pode ser feita em sistema de entrega voluntária ou porta-a-porta. No primeiro caso, são colocados contêineres em pontos estratégicos, ou então são estabelecidas instituições que recebem os materiais, que em ambos os casos são levados pela própria população. No segundo caso, os veículos coletores circulam 
recolhendo os resíduos de casa em casa, como na coleta regular. A segregação de materiais pode, neste caso, ser efetuada seguindo diferentes critérios. Uma das formas mais comuns de segregação é aquela que divide os resíduos em secos e úmidos, correspondendo os primeiros à fração reciclável. É possível também separar os resíduos, para efeito de coleta, num número maior de grupos, dependendo da economicidade, da participação da população e dos equipamentos disponíveis, entre outros fatores.

Além da coleta institucionalizada promovida por órgãos de limpeza pública, existe também a possibilidade de haver atividade informal de catadores e sucateiros, que coletam resíduos seletivamente. Do ponto de vista da sociedade, estes resíduos nem chegam a ser contabilizados como tal, já que houve o reaproveitamento antes da coleta institucionalizada. Como a coleta institucionalizada é geralmente a base dos dados de geração de resíduos, a quantidade coletada informalmente não costuma ser incluída nas estatísticas de geração de resíduos. A título de exemplo, em Porto Alegre a quantidade coletada de forma segregada informalmente é cerca de três

Figura 5.1. Coleta informal de resíduos sólidos em São Paulo (SP) . *

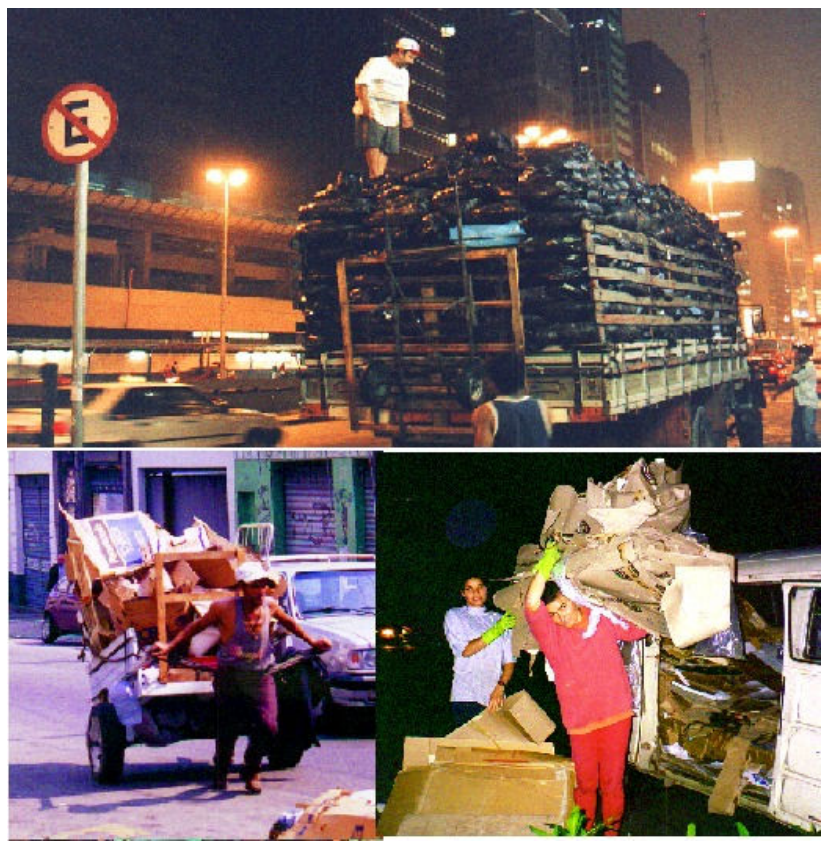

* Fotografias gentilmente cedidas por Henriette Helfant 
vezes maior que a coleta seletiva institucional, e cerca de $10 \%$ do total de resíduos sólidos domésticos coletados pela prefeitura (COSTA e SATTLER 1998). Segundo WELLS (1995) o fator pode chegar a quatro vezes em alguns municípios. Em São Paulo estima-se que a coleta seletiva informal representa $25 \%$ do total de resíduos sólidos domésticos coletados formalmente pela prefeitura (RUBERG e col. 1998).

A coleta de materiais recicláveis presentes nos resíduos existiu durante muito tempo de maneira informal no Brasil, executada pelos próprios garis da coleta ou por catadores, coletando material reciclável de porta em porta ou nos lixões, neste caso em condições sub-humanas.

Para planejar e administrar a coleta, são utilizados alguns parâmetros que medem a sua eficiência. A eficiência da utilização da mão-de-obra de coleta pode ser avaliada pela quantidade de resíduos coletada por pessoa por período de tempo, usualmente uma hora de trabalho.

A taxa de desvio (WELLS e col. 1995) é um índice largamente utilizado para medir o alcance de programas de coleta seletiva. Consiste na relação, em termos percentuais, entre a quantidade de resíduos coletada seletivamente e a quantidade total de resíduos coletada. É utilizado pela facilidade de obtenção de dados para cálculo.

\subsubsection{Transporte}

Os resíduos coletados são então transportados para unidades de tratamento ou para o local de disposição final. O transporte constitui geralmente uma parte importante do custo do sistema de resíduos sólidos. No caso da coleta seletiva, os resíduos recicláveis apresentam uma densidade média cinco vezes inferior à dos resíduos misturados, o que faria supor razoável um custo de transporte cinco vezes maior (CALDERONI 1998). Entretanto, tem se observado que o custo da coleta seletiva ainda é em média oito vezes maior que o da coleta convencional (CEMPRE 1999). Alguns fatores que podem estar contribuindo para este alto custo são a baixa 
adesão da população aos programas, o que leva a baixa eficiência operacional, a falta de vontade política das administrações em efetivamente ampliar a escala dos trabalhos e baixar os custos, além da inclusão de atividades não afetas à coleta, como a triagem, como custo de coleta.

Em princípio, todos os veículos utilizados normalmente para a coleta regular como caminhões de caçamba aberta, tipo prefeitura, compactadores e outros podem também ser utilizados na coleta seletiva. Os veículos compactadores, entretanto, podem introduzir dificuldades na etapa de triagem, além de poder quebrar peças que poderiam ser utilizadas inteiras, como garrafas de vidro. A eficiência de aproveitamento dos veículos pode ser avaliada pela quantidade de material transportada por veículo por hora.

\subsubsection{Tratamento}

O tratamento dos resíduos sólidos visa modificar suas características como quantidade, toxicidade e patogenicidade, de forma a diminuir os impactos ambientais e à saúde pública. As alternativas tecnológicas são aplicadas de acordo com as características particulares de composição dos resíduos, do município ou região e dos recursos disponíveis.

\subsubsection{Triagem}

É uma operação que precede qualquer processo específico de tratamento. O objetivo é separar os materiais que se deseja recuperar, ou aqueles prejudiciais à qualidade do processamento ou à durabilidade dos equipamentos. Pode ser executada manualmente em pátios, mesas ou esteiras rolantes. Podem também ser utilizados métodos mecânicos e automatizados, como equipamentos magnéticos, peneiras, separadores balísticos e transporte. A operação de triagem pode, portanto, ser realizada em usinas, nos lixões, nos sacos à espera de coleta, e outros locais. 
Nos processos manuais, quanto maior o grau de separação desejado e menor a quantidade de impurezas permitida, maior a mão-de-obra envolvida. No caso da separação de materiais a recuperar, os graus de pureza e de limpeza do produto final, e portanto a qualidade da triagem, influenciam sobremaneira o valor de mercado. Após a triagem, os materiais podem ainda ser prensados a fim de baratear o transporte até os locais onde serão industrializados. A eficiência da mão-de-obra de triagem pode ser avaliada pela quantidade de resíduos triados por pessoa por hora.

\subsubsection{Reciclagem}

A reciclagem de resíduos constitui o reprocessamento de materiais, permitindo novamente sua utilização (CALDERONI 1998). Deste modo materiais descartados são reintroduzidos num ciclo produtivo por meio de sua transformação. A reciclagem de resíduos possibilita que materiais que eram considerados resíduos para o gerador passem a ser matérias-primas secundárias para outro indivíduo e para a sociedade como um todo. A reciclagem difere da reutilização porque exige um maior grau de processamento, excedendo a simples triagem e limpeza do material.

Alguns processos de reciclagem podem ser realizados artesanalmente, por exemplo para fins educativos e artísticos. A reciclagem de grandes quantidades de material é realizada normalmente em instalações industriais. Para a reciclagem de cada tipo de material há processos tecnológicos específicos. Alguns deles são baratos e largamente conhecidos, outros precisam ainda ser aperfeiçoados para melhorar a sua economicidade. Resíduos metálicos são fundidos para fabricação de lingotes ou chapas, que servirão de matéria-prima para fabricar novas peças. A reciclagem do alumínio economiza $95 \%$ da energia em relação à utilização do minério (CALDERONI 1998). O vidro também é fundido em novas peças, com economia de $50 \%$ no consumo de água em relação à fabricação a partir das matérias primas primárias (POWELSON cit. por CALDERONI 1998). Plásticos são fundidos e transformados em grânulos, que são usados como matéria-prima para fabricação de novos produtos, com economia de quase $80 \%$ de energia elétrica. (HUFFAM cit. por CALDERONI 1998). Na reciclagem do papel o material é desagregado em água e as 
fibras podem passar ainda por um processo de refinamento antes da utilização. Há ainda soluções criativas, como a fabricação de lixeiras a partir de pneus (Figura 5.2).

A reciclagem traz, em geral, benefícios ambientais. No entanto, é preciso tomar cuidado com decisões apriorísticas, porque é preciso levar em consideração a análise do ciclo de vida do produto, para ter uma visão clara das vantagens e eventuais desvantagens ambientais envolvidas no processo de reciclagem. Para cada região geográfica pode haver vantagens e desvantagens diferentes para a reciclagem de determinados materiais.

A reciclagem de materiais pelas indústrias depende muito da viabilidade econômica. Sobre este processo pesa também a dificuldade de desenvolvimento de mercado para os produtos reciclados, que muitas vezes são vistos como produtos de qualidade inferior. Por outro lado, diversos produtos já fabricados com materiais reciclados não se utilizam ainda do fato de contem materiais reciclados como vantagem competitiva no mercado, preferindo omitir a informação.

\subsubsection{Compostagem}

A compostagem é um processo de estabilização da matéria orgânica por fermentação (OLIVEIRA 1982). Alguns autores a consideram uma forma de reciclagem da matéria orgânica. O produto final é um material granulado conhecido como composto, de grande utilidade por melhorar as propriedades físicas do solo, além de ter propriedades fertilizantes.
Figura 5.2. Lixeiras feitas de pneus usados (Alagoinha - PB)

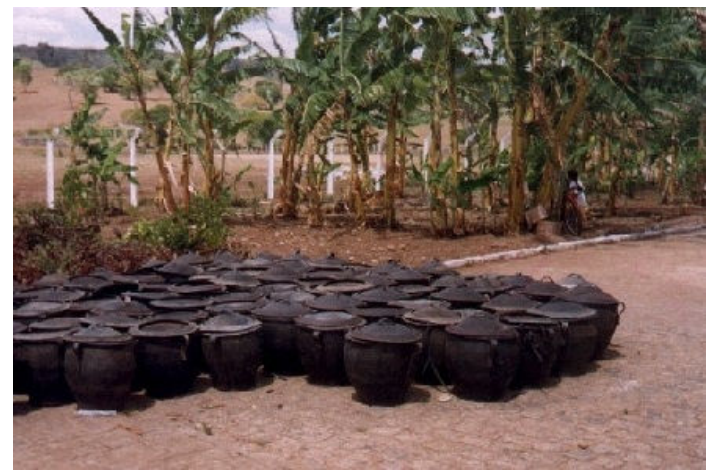


Figura 5.3. Compostagem em montes (Alagoinha - PB)

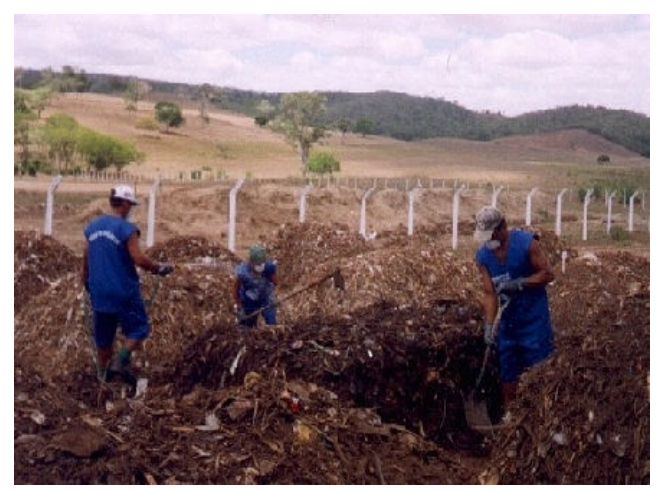

O processo promove a destruição da maioria dos agentes patogênicos normalmente presentes nos resíduos sólidos domésticos porque numa das etapas eles ficam expostos a temperaturas da ordem de 65 a $70^{\circ} \mathrm{C}$. Não é aconselhável o uso em culturas ingeridas cruas, pela existência de certas formas de ovos e cistos que resistem a estas temperaturas.

Há inúmeras alternativas de processos tecnológicos, desde os mais simples como a compostagem em montes periodicamente revirados (Figura 5.3), até instalações de grande porte com tambores rotativos. Pode ser realizada por meio de processos aeróbios, anaeróbios ou mistos. A compostagem é um processo lento, que dependendo da tecnologia empregada pode levar de 45 a 180 dias. Geralmente exige áreas relativamente grandes de pátio para a etapa de cura.

\subsubsection{Incineração}

A incineração constitui um processo de redução de peso e volume dos resíduos através de queima controlada (OLIVEIRA 1982). Os resíduos são reduzidos a cinzas, que representam de 5 a 15\% do peso inicial. São destruídos todos os agentes patogênicos, sendo por isso muito utilizada para tratamento de resíduos de Figura 5.4. Incineração de resíduos de serviços de saúde (Figura 5.4). Também podem ser destruídos diversos compostos químicos tóxicos presentes.

Alguns incineradores são projetados de modo a permitir o aproveitamento da queima para produção servicos de saúde (São José dos Campos -

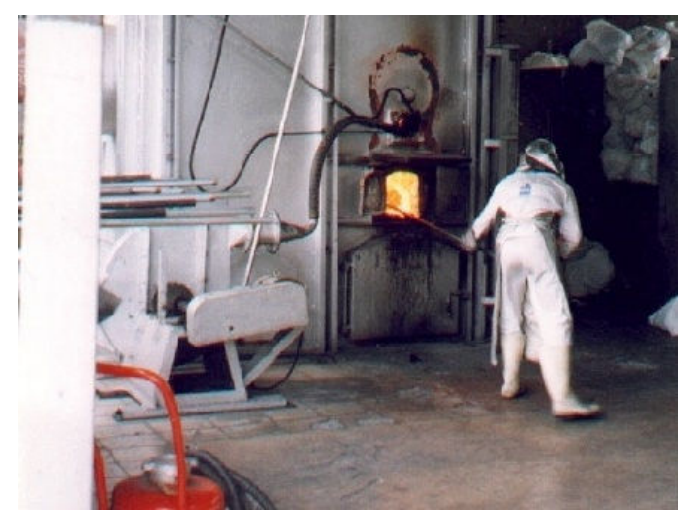


de energia elétrica. Uma das desvantagens deste processo está no risco de produção e emissão de dioxinas e furanos, substâncias tóxicas e cancerígenas que se emitidas com os gases da queima, podem depositar-se no solo, entrar na cadeia alimentar via vegetais e provocar danos ambientais graves. Tecnicamente existem formas de minimizar bastante esta possibilidade, mas a percepção dos riscos associados ao processo e à segurança da tecnologia varia de comunidade para comunidade, o que tem tornado politicamente difíceis e desgastantes as decisões sobre a instalação de novos incineradores e a desativação de equipamentos antigos. As cinzas devem ainda ser aterradas, não dispensando portanto a existência de um aterro. Mas a principal desvantagem deste processo está usualmente no custo elevado.

LEÃO e TAN (1998), num estudo sobre alternativas para o município de São Paulo, mostram que a incineração de alguns componentes dos resíduos sólidos domésticos pode ser economicamente mais interessante que a coleta seletiva e reciclagem, embora investimentos mais expressivos em Educação Ambiental possam inverter esta situação. O mesmo trabalho mostra também que considerando o ponto de vista ambiental e tendo como parâmetro o efeito estufa - o aumento da temperatura da superfície da terra devido ao aumento da presença de certos gases na atmosfera - a reciclagem torna-se mais vantajosa.

Em comunidades com escassez de áreas para aterro ou de fontes de energia, a incineração de resíduos sólidos domésticos é mais largamente utilizada, como por exemplo no Japão, onde até $80 \%$ dos resíduos sólidos domésticos são incinerados (BARBOSA 1995). Em grandes áreas metropolitanas, com o aumento progressivo dos custos dos aterros sanitários, a incineração pode vir a se tornar praticamente inevitável a longo prazo.

Em alguns países as comunidades têm exigido o fechamento de incineradores. Na Alemanha as exigências progressivas quanto à qualidade do ar têm inviabilizado novos investimentos, e assim vem aumentando a fração tratada por compostagem (BUNDESUMWELTMINISTERIUM 1996). Por outro lado, tem sido admitida a incineração de plásticos (BUNDESUMWELTMINISTERIUM 1997), 
porque o mercado de produtos recicláveis de plásticos não seria suficiente para processar todo o material recolhido.

\subsubsection{Outros métodos}

A pirólise é uma decomposição física e química na ausência de oxigênio a temperaturas de 500 a $1000^{\circ} \mathrm{C}$ (OLIVEIRA 1982). Resulta na produção de gases e óleos combustíveis, alcatrão, sulfato de amônia e carvão. Tem pouca aplicação no Brasil. Ainda precisa ser aperfeiçoada tecnológica e economicamente.

A conversão biológica com recuperação de energia baseia-se na atividade microbiana anaeróbia, que produz gases combustíveis. Por meio da construção de digestores apropriados ou da instalação de equipamentos para captação dos gases

produzidos nos aterros sanitários, pode-se gerar energia pela queima de tais gases. É um método que ainda carece de viabilidade econômica na maioria dos casos (LIMA 1991).

O uso de resíduos sólidos domésticos para a alimentação de animais, especialmente de criação, é permitido, desde que os resíduos sejam adequadamente cozidos.

\subsubsection{Disposição final}

Os resíduos não tratados e os rejeitos dos diversos processos de tratamento precisam ser finalmente dispostos no solo, e a solução mais freqüentemente indicada é o aterro sanitário. A existência de alguma forma de disposição final é sempre necessária para absorver os rejeitos.

Os aterros sanitários (Figura 5.5a) são obras de engenharia destinadas a acomodar os resíduos sobre o solo, minimizando os impactos ambientais e os riscos à saúde (OLIVEIRA 1982). Devem possuir drenos para os líquidos percolados que se formam na decomposição natural da matéria orgânica e impermeabilização adequada 
para evitar a contaminação dos aqüíferos. Também precisam dispor de drenos para escoamento dos gases que se formam no processo de fermentação da matéria orgânica. A operação deve incluir cobertura diária dos resíduos com terra, que ajuda a evitar a emanação de maus odores e o crescimento de vetores. Devem ser cercados para evitar a atividade de catadores. Esgotada sua capacidade, a área deve ser recuperada do ponto de vista paisagístico e de utilização pela sociedade, respeitandose as limitações técnicas inerentes às características dos terrenos aterrados com resíduos.

Os aterros sanitários são, na maioria das vezes, considerados a forma mais barata de solução para os resíduos sólidos domésticos em cidades médias e grandes. Com o passar do tempo as áreas disponíveis tendem a se esgotar, provocando aumento de custos devido ao preço dos novos terrenos ou às maiores distâncias em relação aos centros geradores. Aterros sanitários de pequeno porte tendem a ser economicamente inviáveis, por isso para pequenas comunidades a CETESB tem indicado o aterro em valas (Figura 5.5c), como uma solução adequada e economicamente acessível, desde que respeitadas determinadas características técnicas.

Figura 5.5. Formas de disposição final de resíduos sólidos domésticos

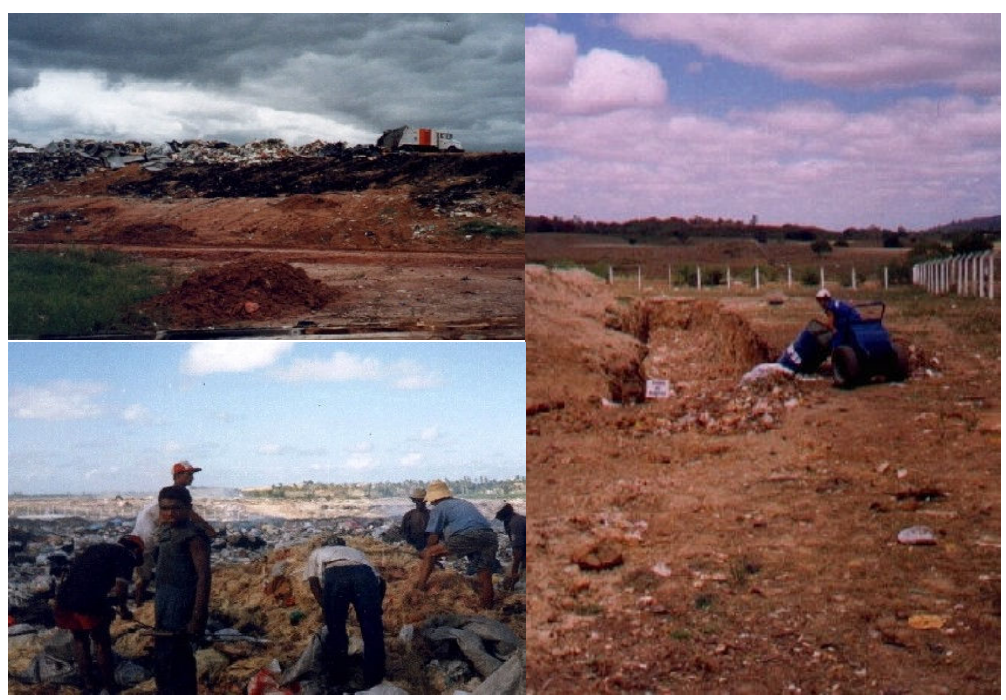

a) Acima à esquerda: Aterro sanitário (São José dos Campos - SP).

b) Abaixo à esquerda: catadores buscam alimento em lixão (João Pessoa - PB)

c) À direita: aterro em valas (Alagoinha - PB) 
As formas de disposição nas quais não existem cuidados para redução de impactos são normalmente chamadas lixões. Não podem, a rigor, ser considerados formas de disposição final, já que dispor significa colocar de forma ordenada (FERREIRA 1993). Os lixões são inadequados do ponto de vista sanitário porque propiciam a proliferação de vetores e o aparecimento de doenças. Podem provocar também poluição do solo, das águas, do ar e diversos incômodos. Do ponto de vista social acabam refletindo a miséria encontrada na região porque são fonte de renda e de alimento para catadores (Figura 5.5b.). Os lixões são a forma mais comum de destinação final no Brasil. (IBGE 1991).

Alguns aterros em condições técnicas intermediárias são chamados aterros controlados. Tipicamente são aqueles que recebem cobertura diária de terra e cujos sistemas de impermeabilização e de drenagem de líquidos e gases não existem ou não preenchem os requisitos técnicos. Esta denominação cumpriu durante algum tempo a função de diferenciar situações de descuido total daquelas que já incorporavam alguns cuidados, mas hoje é considerada imprópria por muitos profissionais, merecendo revisão.

Figura 5.6. Diagrama de fluxo simplificado de um sistema de gerenciamento integrado de resíduos sólidos domésticos.

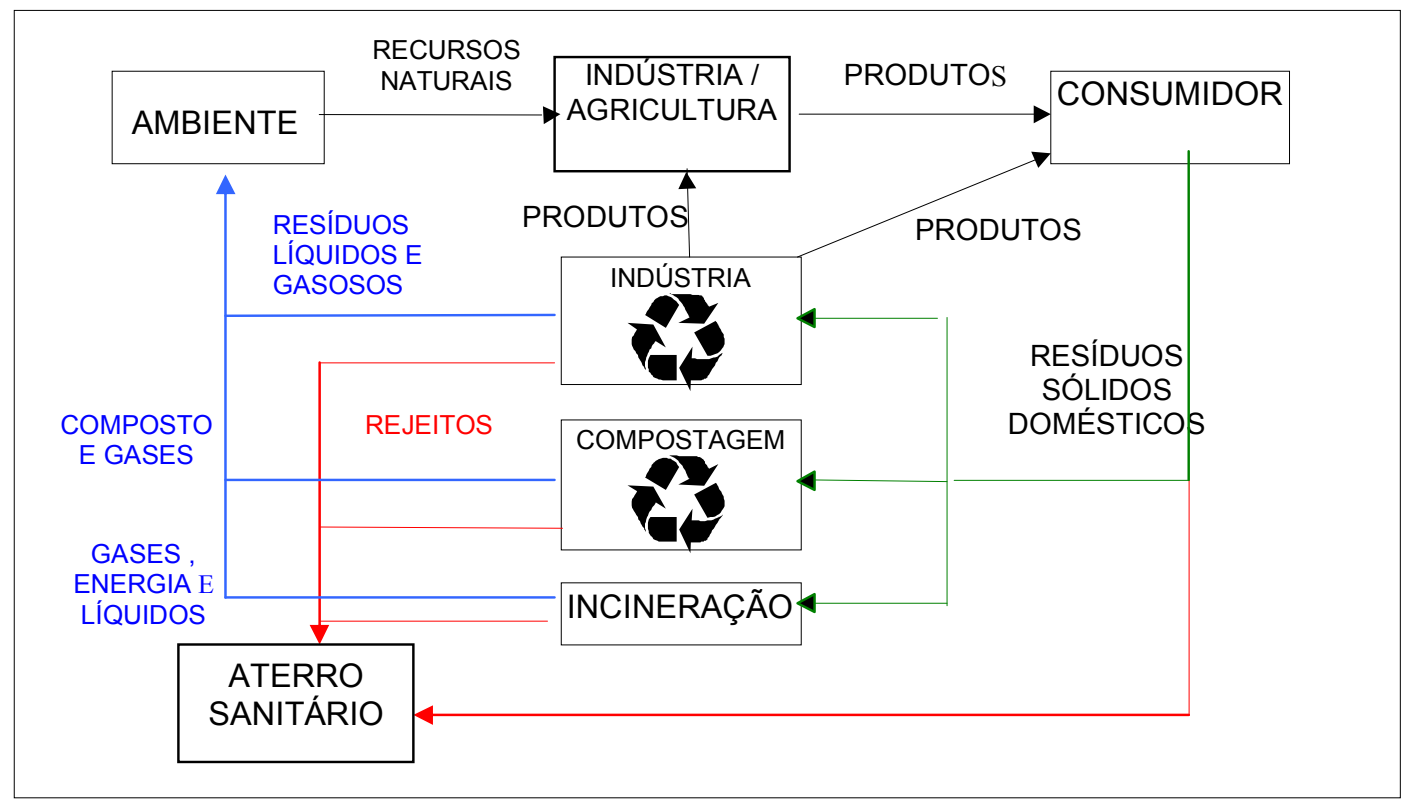




\subsubsection{Os quatro "R"}

O gerenciamento integrado de resíduos (Figura 5.6) consiste na prática de utilizar diversas alternativas para solução do problema dos resíduos sólidos, de tal forma que o conjunto tenha sustentabilidade econômica, ambiental e social. Os sistemas de gerenciamento integrado de resíduos sólidos utilizam-se de medidas simultâneas de redução de geração na fonte, minimização por meio das diversas formas de tratamento, e disposição, de acordo com as condições locais, em proporções econômicas, sociais e ambientais ótimas. Nenhuma dessas medidas é capaz, de forma isolada, de solucionar os problemas de destinação dos resíduos sólidos domésticos (BARCIOTTE 1993 e WELLS e col. 1995).

Uma forma muito comum de abordar este sistema integrado incluindo as mudanças de padrão de consumo é através da priorização dos três $R$ 's, sendo que alguns autores acrescentam um quarto R:

a) Reduzir: significa estabelecer padrões de consumo que diminuem a produção de resíduos nas fontes geradoras. A redução da quantidade de resíduos produzidos tem um efeito direto nos custos de coleta e de disposição final de resíduos, além da economia de água, energia e outros recursos naturais. Alguns exemplos possíveis: utilizar engradados reutilizáveis ao invés de saquinhos plásticos para transporte de compras em supermercados; imprimir trabalhos por computador somente quando necessário; preferir o correio eletrônico ao papel para correspondência; escolher produtos mais duráveis, consertar ou atualizar tecnologicamente equipamentos antigos ao invés de comprar novos. Deve-se tomar cuidado para, ao realizar estas escolhas, verificar se não há outros aspectos ambientais envolvidos que possam resultar em outros danos ambientais.

b) Reutilizar: significa utilizar o produto novamente, para a mesma finalidade ou para outra, sem necessidade de transformação do material, como é o caso das 
garrafas retornáveis (Figura 5.7), ou a utilização da face em branco

Figura 5.7. Garrafas recolhidas de resíduos sólidos domésticos prontas para serem retornadas a de papéis já utilizados de um fabricantes de bebidas (São José dos Campos - SP).

lado. Da mesma forma proporciona economia de coleta e disposição final, de matériasprimas, e geralmente também de água e energia.

c) Reciclar: Pelos benefícios

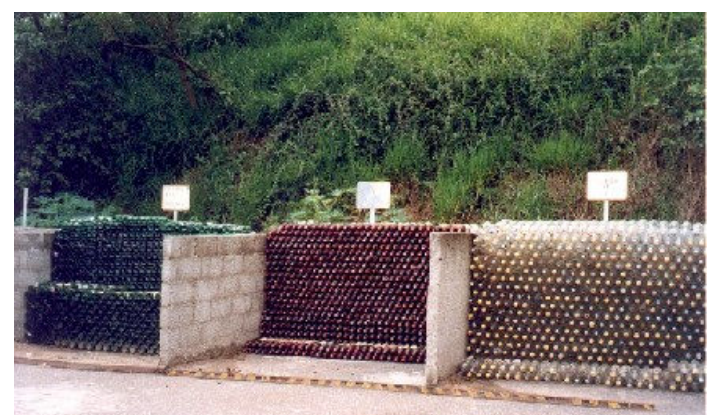
ambientais que potencialmente proporciona, é considerada normalmente uma das soluções prioritárias. Porém a fantasia de que o ciclo da reciclagem pode ser infinito pode também contribuir para justificar o aumento do desperdício. A realidade é que em todo processo de reciclagem sempre há perdas, ou seja, não se consegue aproveitar $100 \%$ do material.

d) Recuperar energia: por meio de incineração de resíduos, com as vantagens e desvantagens já descritas. Também não proporciona redução no custo da coleta, mas traz as maiores economias na utilização de áreas para aterro sanitário.

Ressalte-se aqui a importante diferença entre redução da geração na fonte, que se refere à diminuição da geração de resíduos, e a minimização de rejeitos para aterro, que se refere à diminuição dos rejeitos por meio do aumento da fração de resíduos gerados que é recuperada. A minimização inclui a reutilização, a reciclagem, a compostagem, a recuperação de energia e qualquer outra forma de tratamento que diminua o volume ou a periculosidade dos resíduos a serem dispostos em aterro.

Um indicador bastante útil da minimização é a taxa de recuperação, que é a relação, em termos percentuais, entre a quantidade de materiais recuperados 
(reutilizados, reciclados ou compostados) e uma quantidade de resíduos gerados de referência (BIOCYCLE STAFF 1995).

\subsection{Aspectos econômicos e análise custo-benefício}

CHERMONT e MOTTA (1996) chamam a atenção de que existe um nível ótimo de reciclagem, abaixo do qual falta à atividade a economia de escala, e acima do qual a viabilidade econômica desaparece pelo aumento dos custos marginais para ampliação da abrangência em termos de área geográfica ou número de habitantes atendidos. É importante, em cada realidade local, buscar conhecer este ponto, para definir se serão necessárias políticas públicas ou mesmo se valem a pena novas políticas para modificar esta realidade e viabilizar um nível maior de recuperação.

CALDERONI (1998) mostra algumas formulações alternativas para a análise custo-benefício do processo de coleta seletiva e reciclagem de resíduos sólidos. A mais abrangente delas estabelece que os custos associados à coleta seletiva e reciclagem dos resíduos domésticos podem ser divididos em:

a) Custos incorridos: triagem, enfardamento, armazenamento, transporte e outros.

b) Custos evitados: disposição final em aterro e, quando aplicável, transbordo e transporte adicional.

c) Ganhos: energéticos, de controle ambiental e de consumo de água.

Atualmente já se reconhece a importância dos ganhos referidos no item (c), estando em desenvolvimento inclusive diversas metodologias para tal quantificação. São ganhos da sociedade como um todo, que não são percebidos na maioria das vezes pelos atores individuais, e por isso não são usualmente incluídos no balanço custo/benefício pelas entidades promotoras dos programas de coleta seletiva e reciclagem. Por ter-se estabelecido para o presente estudo o foco nas parcerias, e portanto na ação de atores, o item (c) será representado pelo faturamento com a venda dos materiais, ou seja: 


\section{$\mathrm{C}=\mathrm{I}-\mathrm{E}+\mathrm{V}(\mathbf{5 . 1})$}

onde :

$\mathrm{C}=$ custo total, $\mathrm{R} \$ / \mathrm{t}$

$\mathrm{I}=$ custos incorridos, $\mathrm{R} \$ / \mathrm{t}$

$\mathrm{E}=$ custos evitados, $\mathrm{R} \$ / \mathrm{t}$

$\mathrm{V}=$ preço de venda, $\mathrm{R} \$ / \mathrm{t}$.

Conforme explica CALDERONI (1998), do ponto de vista da sociedade a parcela $\mathrm{V}$ é cancelada porque a receita de um ator é cancelada pela despesa do outro.

Os custos evitados, no caso das prefeituras municipais, são representados entre outros pela correspondente diminuição da necessidade de aterro sanitário ou incineração, em função do material que é reciclado.

Tabela 5.1. Custos de diferentes opções de tratamento e disposição final de resíduos sólidos em diversos países, em US\$/t.

\begin{tabular}{l|c|c|c|c}
\hline \multirow{2}{*}{ Item } & \multicolumn{4}{|c}{ Custos (US\$ $/$ ) } \\
\cline { 2 - 5 } & $\begin{array}{l}\text { América Latina e } \\
\text { Caribe }\end{array}$ & Estados Unidos & Alemanha & Brasil \\
\hline Coleta Regular & $15-40(\mathrm{a})$ & & & $30(\mathrm{f})$ \\
Coleta seletiva & & $40-74(\mathrm{~d})$ & $60(\mathrm{~b})$ & $230(\mathrm{e})$ \\
$\begin{array}{l}\text { Compostagem } \\
\text { Incineração }\end{array}$ & & $90(\mathrm{a})$ & $150(\mathrm{c})$ & \\
$\begin{array}{l}\text { Aterro sanitário } \\
\text { Triagem }\end{array}$ & 6 & $30(\mathrm{a})$ & $90-240(\mathrm{c})$ & $12(\mathrm{f})$ \\
\hline
\end{tabular}

Adaptado de: (a) ACURIO et al. (1997); (b) BUNDESUMWELTMINISTERIUM (1996a); (c) BUNDESUMWELTMINISTERIUM (1996b); (d) BIOCYCLE STAFF (1995); (e) CEMPRE (1999); (f) CALDERONI (1998).

Os custos das diferentes formas de coleta, transporte, tratamento e disposição final de resíduos sólidos variam largamente conforme as tecnologias utilizadas e as condições locais. A Tabela 5.1 mostra alguns dos custos indicados em bibliografia, em alguns países, para várias etapas dos sistemas de resíduos sólidos. Note-se que o dado do CEMPRE (1999) para coleta seletiva considera uma metodologia que 
mistura, em muitos casos, operações de triagem à coleta seletiva. Os valores referidos em marcos alemães foram convertidos para dólares americanos.

Muitos gestores municipais, empresários, e por vezes também técnicos, buscam respostas fechadas para a questão da viabilidade econômica da coleta seletiva. CALDERONI (1998) propõe acrescentar “para quem?” a esta questão. Ele estabelece uma metodologia de cálculo dos ganhos com reciclagem do ponto de vista do sucateiro, da indústria, da prefeitura e do conjunto da sociedade. Segundo o autor, a maior parte dos ganhos, da ordem de $65 \%$, fica com a indústria, sendo o restante dividido entre sucateiros, carrinheiros e prefeitura. Deve haver viabilidade econômica para todos os atores da cadeia para que ocorra a viabilidade econômica da reciclagem, sob pena de interrupção da cadeia e inviabilização do processo como um todo. A questão então é como promover esta viabilidade para cada um dos atores e em todas as etapas. Dada a diversidade de situações existentes no país (cidades pequenas e cidades grandes, diferentes culturas, diferentes perfis econômicos em cada região, não há uma solução única.

Para as indústrias e sucateiros a reciclagem deve gerar lucro, mas para outras instituições o lucro não é essencial No caso das prefeituras, a viabilidade econômica costuma ser estabelecida através da comparação entre os custos da solução atual e os custos da coleta seletiva em termos financeiros absolutos e imediatos. Em alguns casos, a viabilidade econômica poderia ser entendida também como a autosustentação do projeto, ou seja, a independência de recursos externos ou subvenções. Do ponto de vista da sociedade como um todo, é preciso quantificar outros ganhos como energia, água, economia de divisas em matérias-primas, ganho social e outros, conforme já discutido anteriormente.

\subsubsection{Custos unitários globais da coleta seletiva}

O indicador mais utilizado para o custo global da coleta seletiva é o custo

unitário por tonelada coletada. É calculado dividindo-se o total de despesas do 
programa pela quantidade de resíduos coletados ou reciclados. $\mathrm{Na}$ maioria das vezes o indicador é calculado em relação à quantidade de resíduos coletada, e às vezes em relação à quantidade de resíduos efetivamente reciclada, que é o parâmetro adotado neste trabalho. Algumas vezes são descontados dos custos o valor arrecadado com a venda dos materiais.

\subsubsection{Componentes dos custos de coleta e triagem}

O custo da coleta corresponde a custos de investimento, de operação e de mão-de-obra (PHILIPPI JR. 1979). Basicamente a mesma estrutura pode ser atribuída aos custos de triagem.

Custos de capital são os investimentos necessários para aquisição ou aluguel de veículos, equipamentos, terrenos e edifícios. Estes custos podem ser incorporados ao custo unitário utilizando a depreciação dos equipamentos. O custo de depreciação deveria considerar o desgaste dos equipamentos O período de depreciação depende do tipo e qualidade do equipamento, e da experiência de cada profissional.

Os custos de operação da coleta incluem combustíveis, manutenção inclusive pneus, lubrificantes e mão-de-obra. Em ambos os casos os custos de mão-de-obra devem incluir os salários e os benefícios sociais decorrentes.

Os custos de operação da triagem devem incluir materiais como ferramentas e equipamentos de proteção individual e também água e energia elétrica.

Os custos totais das etapas de coleta seletiva e reciclagem dos programas correspondem à somatória dos custos de coleta e transporte, triagem e reciclagem.

$$
\mathrm{I}=\mathrm{C}+\mathrm{T}+\mathrm{R}
$$


Onde:

$\mathrm{I}=$ custos incorridos $(\mathrm{R} \$ / \mathrm{t})$

$\mathrm{C}=$ custo da coleta e transporte $(\mathrm{R} \$ / \mathrm{t})$

$\mathrm{T}=$ custo da triagem $(\mathrm{R} \$ / \mathrm{t})$

$\mathrm{R}=$ custo da industrialização $(\mathrm{R} \$ / \mathrm{t})$

\subsubsection{Indicadores do mercado de materiais recicláveis}

Os preços dos materiais alcançados dão indicações importantes com relação ao mercado. Há diferenças regionais importantes e a comparação entre as diversas regiões é um instrumento bastante útil.

Segundo CALDERONI (1998), os sucateiros enfrentam oligopsônios mercados em que há poucos compradores - o que significa que na maioria das vezes as indústrias impõem os preços, de modo a manter a lucratividade da atividade dos sucateiros em patamares baixos. Deste modo eles procuram trabalhar mais com o mercado informal, contratando catadores, que não recebem os benefícios previstos na legislação.

Outro indicador importante é a porcentagem de cada material no total de materiais vendidos, já que cada material tem aceitação diferente pelo mercado em cada região. Este índice é reflexo não apenas da composição dos resíduos domésticos, mas também da preferência por parte de quem coleta pelos materiais que lhes dão melhor rendimento financeiro. A porcentagem do faturamento devida a cada material também pode dar informações interessantes. 


\section{EXPERIÊNCIAS NACIONAIS E INTERNACIONAIS}

Tanto no âmbito nacional quanto no internacional são visíveis as mudanças na forma de gerenciar resíduos sólidos domésticos ocorridas nos últimos anos. Diversos exemplos são relatados em referências bibliográficas e no noticiário jornalístico. Neste capítulo são descritos a situação geral de alguns países específicos e alguns exemplos significativos de experiências relatadas na literatura.

\subsection{Experiências e tendências internacionais}

Nos países mais desenvolvidos as quantidades de resíduos sólidos domésticos geradas por habitante são maiores que nos países em desenvolvimento, e as preocupações com minimização e redução de geração parecem estar mais presentes. A coleta seletiva faz parte do dia-a-dia da população desses países. Os "selos verdes", que atestam vantagens ambientais são utilizados com mais freqüência nos produtos de consumo, permitindo aos consumidores melhor informação e possibilidade de decisão mais consciente quanto a comprar produtos ambientalmente mais adequados e que gerem menor quantidade de resíduos.

O cenário internacional mostra que as parcerias vêm sendo bastante aplicadas para viabilização de programas de coleta seletiva e reciclagem de resíduos sólidos domésticos. São descritos a seguir o panorama geral em alguns países de e algumas experiências específicas.

\subsubsection{Alemanha: o sistema dual}

$\mathrm{Na}$ Alemanha são gerados aproximadamente 28 milhões de toneladas anuais de resíduos domésticos, o que significa uma geração per capita aproximada de 1 kg/dia/habitante. 
No final dos anos 80 o movimento ambientalista conseguiu bastante espaço político. Nessa época uma série de políticas públicas e novos instrumentos legais foram discutidos ou entraram em vigor. Entre os instrumentos legais desenvolvidos nessa época e implementados no início dos anos 90 está o Regulamento das Embalagens, que determinou que fabricantes de produtos são responsáveis pela coleta e reciclagem das embalagens descartáveis utilizadas, inclusive embalagens secundárias e de transporte (BUNDESUMWELTMINISTERIUM 1991). No caso dos produtos de consumo, os comerciantes receberam a obrigação de aceitar a devolução das embalagens descartadas, devendo encaminhá-las de volta ao fabricante. Também foram estabelecidas cotas mínimas de reciclagem por material e cotas de embalagens retornáveis, com valores de depósito reembolsável para alguns produtos. Há também outros instrumentos legais que estabelecem a responsabilidade do fabricante para outros tipos de produtos, como automóveis, eletroeletrônicos e outros.

As obrigações estabelecidas no Regulamento das Embalagens levaram um grupo de 91 empresas a montar um sistema dual de coleta de embalagens e reciclagem, administrado no início por um consórcio que chegou a ter mais de 600 empresas (DSD 1996). O DSD - Duales System Deutschland atualmente é uma empresa de capital aberto. Tem movimentado anualmente 4 bilhões de marcos alemães, ou aproximadamente US\$ 2,5

Figura 6.1. O "Ponto Verde"

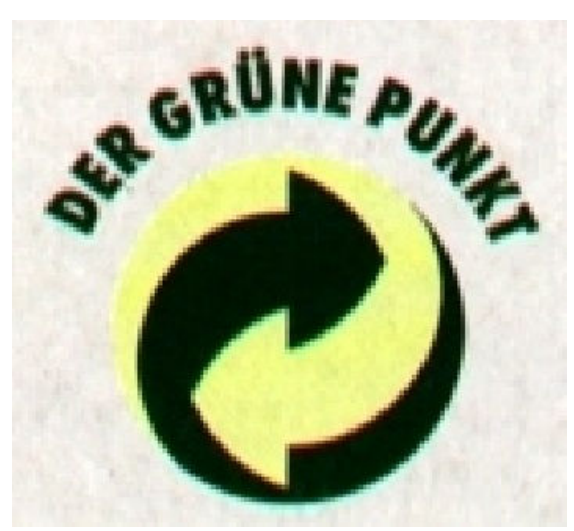
bilhões. (COOPER MH 1998). Das aproximadamente 6.400 .000 toneladas de embalagens consumidas, 5.350 .000 foram coletadas em 1995 e 4.900 .000 foram recicladas (DSD 1996).

O sistema funciona através da venda da licença para uso do selo Ponto Verde (Figura 6.1), que é impresso nas embalagens dos produtos dos fabricantes associados. $\mathrm{O}$ 
símbolo indica que a empresa fabricante do produto já pagou pela coleta e destinação da embalagem usada.

O DSD executa coleta seletiva utilizando-se de formas operacionais adaptadas a cada localidade. São firmados contratos com empresas que efetuam coleta e com empresas recicladoras que garantem o processamento dos diversos materiais coletados. Há também parcerias com os municípios, a fim de integrar a coleta seletiva das embalagens aos sistemas existentes e à coleta de materiais recicláveis não originados das embalagens. Segundo COOPER MH (1998) há 360 usinas de triagem operando, mas o DSD estima que em uma década estarão reduzidas a 80 ou 100 unidades mais automatizadas.

Como resultado da iniciativa, houve redução de geração de resíduos de embalagens, já que as empresas passaram a buscar a redução do custo da destinação. A maioria das metas de reciclagem previstas para 1995 foram alcançadas, e novas metas foram estabelecidas na revisão do regulamento (BUNDESUMWELTMINISTERIUM 1997).

Existem também casos de fraude no uso do Ponto Verde e de coleta de materiais recicláveis que não são embalagens, o que tem sido resolvido com parcerias com o poder municipal. Entre os problemas que ocorreram está o déficit grave de 300 milhões de dólares em 1993, que exigiu um socorro financeiro do governo. Houve também o desaparecimento de iniciativas independentes e de pequenas e médias empresas que faziam a reciclagem, por causa do monopólio em que se transformou o DSD. Na atualização do regulamento, em 1997, foi oferecido um prazo de dois anos para que novos sistemas tivessem tempo para se desenvolver e atingir as cotas legais. No caso particular dos materiais plásticos, houve problemas de exportação ilegal, como uma tentativa de contornar a falta de capacidade do parque industrial alemão de processar no próprio país os resíduos coletados. (BUNDESUMWELTMINISTERIUM 1997). 


\subsubsection{Grã-Bretanha: em busca dos investidores privados}

A Diretiva da União Européia sobre Embalagens e Resíduos de Embalagens, implementada em 1994, cobre somente embalagens de venda ao consumidor, não englobando embalagens secundárias e de transporte. Também estabelece cotas de recuperação de materiais. A Grã-Bretanha, para se adequar à regra da União Européia, implementou em 1997 seu regulamento, que engloba todos os tipos de embalagens. Entretanto, por ter iniciado mais tarde, esse país deve ter mais dificuldades para cumprir a meta estabelecida para a União Européia. Foram implantados sistemas privados de coleta das embalagens, entre os quais o VALPAK é o sistema dominante, com 2.500 membros do total de 3.880 empresas registradas. Há uma competição com os outros sistemas menores, de modo que é previsível para o futuro a diminuição dos custos (COOPER MH 1998)..

Quanto à organização dos serviços de coleta, eles já vêm sendo privatizados há muitos anos. Entretanto, no âmbito legal, têm sido feitos ajustes para que possam ser admitidos investimentos privados para outras operações do sistema de resíduos sólidos, eliminando algumas barreiras legais que havia quanto ao compartilhamento dos riscos dos negócios envolvidos, e quanto à autonomia das autoridades locais para consolidar as necessárias parcerias (O’KEEFE e RICE 1998). O sistema de financiamento pela iniciativa privada recentemente regulamentado caracteriza-se pelo fornecimento de serviços por um parceiro da iniciativa privada, direcionado por princípios bem definidos como especificação baseada em resultados, transferência de risco ótima e pagamento baseado no desempenho (PORTNELL 1998).

\subsubsection{Estados Unidos: o mercado regulando a reciclagem}

Os Estados Unidos produzem 327,5 milhões de toneladas de resíduos sólidos domésticos por ano. A taxa de reciclagem tem se situado entre 27 e $28 \%$, incluindo a compostagem e parte dos resíduos industriais de alguns estados (GOLDSTEIN 1997). A maior parte do material reciclado é papel. Pouco mais da metade da população é servida por coleta seletiva porta-a-porta, e apesar de a taxa de 
reciclagem estar estabilizada, o número de programas de coleta porta-a-porta e de entrega voluntária tem aumentado. A incineração tem se situado em torno de $10 \%$ e o restante dos resíduos é aterrado. Alguns estados estabeleceram metas de reciclagem, embora não haja a responsabilidade do produtor. Estados repassaram para os municípios em 1996 mais de US\$ 180 mi para aplicação em programas de reciclagem (GOLDSTEIN e GLENN 1997).

Nos Estados Unidos a EPA - Environmental Protection Agency tem atuação na produção de material educativo para redução da geração de resíduos, e tem também incentivado as formas participativas de solução do problema dos resíduos sólidos na comunidade, como o Manual do Consumidor para reduzir os resíduos sólidos (EPA 1992). Além disso em muitas comunidades se pratica a coleta seletiva. Em vários estados norte-americanos já se estabelecem cotas mínimas de reciclagem (GOLDSTEIN 1997).

Dos Estados Unidos partem as críticas mais duras ao modelo alemão, devido ao custo adicional que representa o modelo e ao fato de não deixar livres as forças de mercado para definirem a proporção ideal de reciclagem, por exemplo PORTER (1993).

\subsubsection{Outras experiências}

Em Montreal (Canadá) o município gastou US\$ 27.000.000 com coleta seletiva em 1994, para atender 200.000 lares e operar 123 PEVs. O custo inicial de implantação foi de US\$ 626.600. Há uma usina central de reciclagem onde trabalham mais de 120 pessoas. O fato de ser central facilita a regularidade do fornecimento de material reciclável. A usina tem capacidade para processar $40 \mathrm{t} / \mathrm{h}$. Em 1994 grupos comunitários e entidades ambientalistas fizeram trabalho porta-aporta de divulgação, e houve parcerias com iniciativa privada para dividir custos do material de divulgação (WALKER 1995). 
Na cidade de Cairo (Egito) o sistema de serviços de coleta de resíduos sólidos sofreu bastante com o crescimento explosivo da cidade, de modo que uma boa parte dos resíduos sólidos domésticos não era coletado pelo serviço municipal. Catadores conhecidos como zabbaleen - coletavam os resíduos, separando materiais reaproveitáveis para vender e utilizando a fração orgânica para criação de porcos. Realizavam suas atividades em condições sanitariamente inadequadas. O sistema foi reformulado com o assentamento dos zabballen em áreas próprias, reurbanizadas e com formação de cooperativas de catadores e de microempresas de reciclagem. Iniciativa de uma $\mathrm{ONG}$, contou com apoio de organismos internacionais, como a Fundação Ford e de órgãos dos governos local e nacional (THE MEGA CITIES PROJECT 1995).

A reciclagem é amplamente praticada na América Latina, mas a quantidade de material reciclado não é grande em relação ao total de resíduos gerados. Há projetos piloto de coleta seletiva porta-a-porta em Buenos Aires e em Cali. Em Lima a atividade de 5.000 catadores recupera aproximadamente 290 t diárias. Na Colômbia há muitos trabalhos de sucesso na organização de catadores. Na Venezuela há 199 centros de recuperação, que trabalham somente com grandes geradores. Além disso se tem notícia, há muitos anos, da existência de coleta informal no Brasil e em outros países da América Latina, mesmo antes de se estudar a institucionalização desta atividade (ACURIO e col. 1997).

Em Temuco, no Chile, desenvolve-se desde 1995 o Projeto Andes, para reciclagem dos resíduos sólidos domésticos da cidade, uma iniciativa da Universidad de la Frontera. Os trabalhos junto aos catadores informais foram desenvolvidos pela própria Universidade. Do grupo de 20 catadores iniciais permanecem na associação formalizada 13, os quais coletam uma média de 16,5 t mensais de materiais recicláveis. O sucesso do programa é atribuído, entre outros fatores, ao cumprimento dos compromissos assumidos com os catadores e ao aproveitamento de recursos já existentes na sociedade local. Houve além disso bastante apoio da mídia impressa e das rádios locais, mas nenhum apoio da rede de televisão local. Mais tarde uma produtora que trabalhava para a Televisión Nacional Central executou um 
documentário de 16 minutos divulgado em todo o país. Depois de aproximadamente dois anos e meio da implantação a gestão foi entregue à Prefeitura Municipal. Esta transferência foi uma etapa difícil, e foi especialmente importante a visita de um técnico e de um político do Município às cidades de Curitiba e Belo Horizonte, no Brasil, que à época já contavam com programas bem estruturados. (TOSTI-CROCE e col. 1998).

\subsection{Experiências brasileiras: dez anos de coleta seletiva organizada}

As primeiras experiências de coleta seletiva organizada e integrada aos sistemas de resíduos sólidos no Brasil datam do final da década de 80 e início da década de 90. Como forma organizada e institucionalizada, a coleta seletiva começou a ser implantada no Brasil no final da década de 80 , sendo o primeiro programa implantado a coleta no bairro de São Francisco, em Niterói - RJ (EIGENHEER 1993).

Figura 6.2. Programas de coleta seletiva em municípios brasileiros segundo grandes regiões

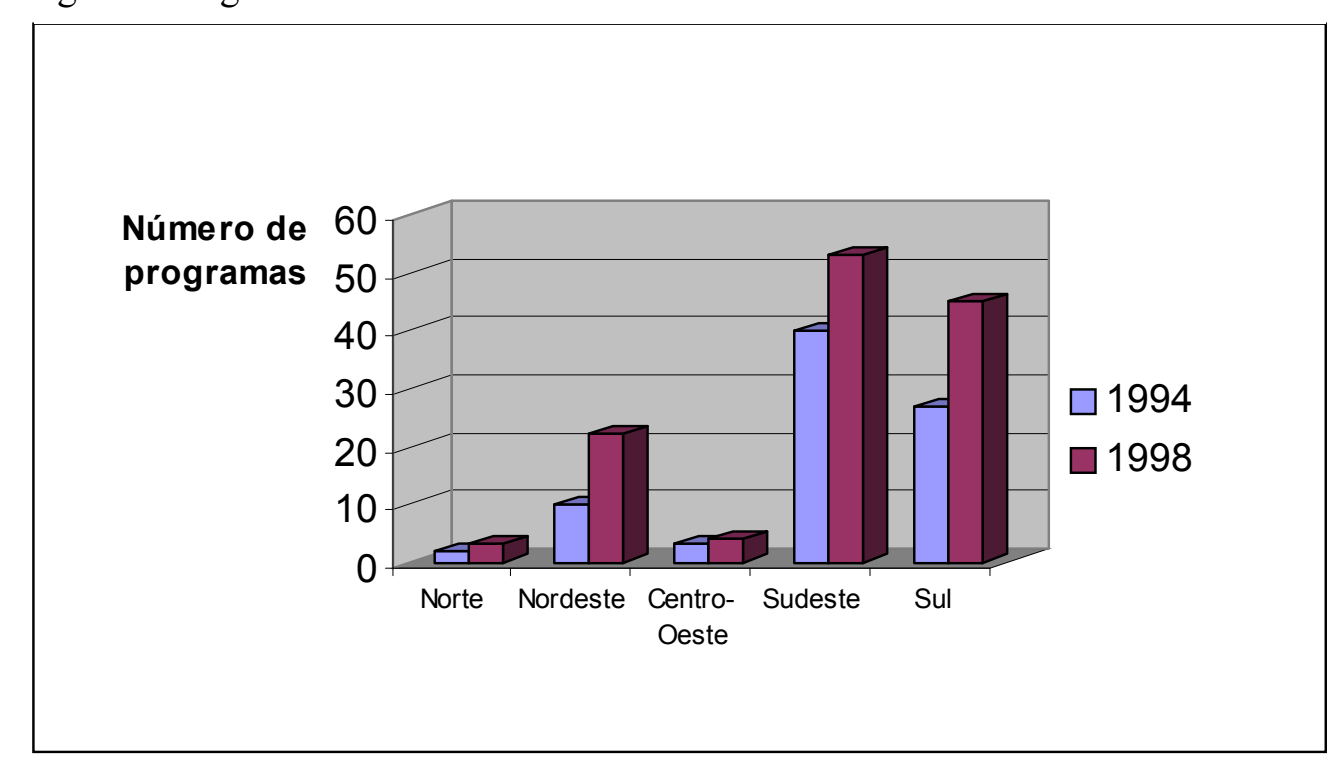

A Figura 6.2 mostra a evolução dos programas de coleta seletiva no Brasil. Houve um maior crescimento nas regiões Sul e Nordeste que na região Sudeste. 
Apesar da evolução dos programas, o custo médio da coleta seletiva mudou relativamente pouco no período de 1993 a 1999que era de US\$240 em 1993 (WELLS e col. 1995) estava em US\$ 222 antes da crise cambial de janeiro de 1999.

Para o presente trabalho, foram identificados diversos programas em muitas referências bibliográficas e na mídia jornalística, das quais foram selecionadas algumas como significativas em termos de seu impacto e das parcerias envolvidas. Um espaço especial é destinado aos programas de Belo Horizonte e Porto Alegre, porque alguns dos dados desses municípios serão utilizados para comparação com resultados obtidos nos trabalhos de campo.

\subsubsection{Belo Horizonte}

Capital do estado de Minas Gerais, o município de Belo Horizonte tem aproximadamente 2.250.000 habitantes e gera cerca de 1.200 t/dia de resíduos domésticos. Desde 1993 vem sendo operada a coleta seletiva, com progressivo avanço na quantidade de materiais segregados. Os materiais são coletados nos Locais de Entrega Voluntária (LEVs), onde há contêineres instalados para coleta dos materiais, separando-se vidro, papéis, plásticos e metais. A SLU - Superintendência de Limpeza Urbana - coleta a maior parte das 334 toneladas diárias da coleta seletiva utilizando-se de mão-de-obra própria e veículos próprios e alugados. Os catadores realizam o restante da coleta. Atualmente cada catador tem que atingir uma meta mínima de $100 \mathrm{~kg}$ coletados por dia, o que tem contribuído para melhoria do rendimento do seu trabalho. A instalação de três galpões de triagem para funcionamento da parceria com a Associação dos Catadores de Papel permitiu eliminação de pontos de triagem em calçadas. O material é comercializado pela Associação dos Catadores de Papel e pela Santa Casa de Misericórdia.

Em 1996, era atendida 95\% da população. As atividades de Educação Ambiental priorizaram os espaços multiplicadores institucionais. Interessante notar que cada LEV tem um adotante que é responsável por avisar o SLU ou a Associação 
dos Catadores quando houver qualquer problema ou quando os contêineres estiverem cheios (MOTTA 1998).

A SLU tem 82 parcerias em projetos estratégicos que viabilizam contêineres para coleta seletiva, lixeiras para vias públicas, veiculação de mensagens educativas em tapumes de construção civil, lixeiras plásticas para veículos, aporte de recursos por entidades de fomento como FNMA, incluindo recursos externos, como do programa LIFE da ONU (SMA 1998a).

\subsubsection{Porto Alegre}

Capital do Rio Grande do Sul, a cidade de Porto Alegre tem cerca de 1.800.000 habitantes (IBGE 1998) e coleta cerca de 1.300 t/dia de resíduos sólidos domésticos.

A coleta seletiva se iniciou em julho de 1990. Atualmente são arrecadadas 40 t/dia de lixo seletivo em $20 \mathrm{PEVs}$ e na coleta porta-a-porta. Cem funcionários do DLU - Departamento de Limpeza Urbana - executam a coleta utilizando 19 caminhões sem compactação (carroceria alterada). Há esquemas específicos para coleta em hospitais, condomínios, órgãos públicos e empresas. O material é distribuído atualmente a oito associações de catadores formalmente constituídas e autônomas, permanentemente acompanhadas por funcionários da Prefeitura. A triagem é realizada em galpões cedidos pela prefeitura. (PEREIRA e SANTOS 1998). Cada reciclador ganha de $\mathrm{R} \$ 150,00$ a $\mathrm{R} \$ 200,00$ (SMA 1998a) como rateio da associação ou cooperativa. Além da coleta municipal, há um intenso trabalho de aproximadamente 1.240 catadores informais que coletam diariamente 125 toneladas de material reciclável (COSTA e SATTLER 1998).

As atividades de educação ambiental são realizadas casa a casa e nas associações, escolas e outras organizações. 


\subsubsection{Outros projetos}

Segundo EIGENHEER (1998), o projeto do bairro de São Francisco (Niterói - RJ) foi o primeiro projeto sistemático e documentado de Coleta Seletiva de Lixo no Brasil. Iniciativa da Universidade Federal Fluminense em conjunto com o Centro Comunitário de São Francisco (associação de moradores do local), com o apoio da GTZ (órgão de cooperação técnica do governo alemão), e posteriormente da FINEP Financiadora de Estudos e Projetos, do governo canadense e da Genève Tiers Monde. Buscou um trabalho de recuperação de matérias-primas do lixo doméstico, descentralizado, auto-financiável e administrado pela comunidade. Posteriormente a UFF realizou outros trabalhos semelhantes em comunidades diferentes. Atualmente livros são coletados de forma diferenciada, podendo ser doados para escolas ou vendidos. São recolhidos também eletrodomésticos, roupas e materiais de construção. A venda dos materiais é insuficiente para cobrir os custos do programa, sendo a diferença bancada pelo Programa de Reciclagem da Brahma. Como contrapartida, a logomarca da empresa é divulgada nos equipamentos, uniformes e comunicações à comunidade.

O Programa Permanente de Coleta Seletiva do Conjunto Nacional (São Paulo - SP) foi implantado com o apoio do UNIBANCO Ecologia. O dinheiro arrecadado com o material vendido é revertido para ajuda de custo para material escolar dos funcionários do condomínio e para o $14^{\circ}$ salário deles. A separação é feita nos escritórios (SMA 1998a).

Em São Paulo (SP) a coleta porta-a-porta iniciou-se em 1989 no bairro da Vila Madalena, num programa piloto e se expandiu para 33 circuitos atendendo 510 mil habitantes. Eram coletadas 10 t/dia. Aproximadamente 160 PEVs estavam instalados em 1992. Os altos custos levaram a administração municipal a interromper o programa, mantendo apenas alguns PEVs, que durante muito tempo ficaram em situação de abandono. Os PEVs da Avenida Paulista, em frente à Casa das Rosas (Figura 6.2) já foram inclusive retirados do local. Segundo ALBOREDA (1993a), os 
Figura 6.3. Contêineres de entrega voluntária - São Paulo 1998.

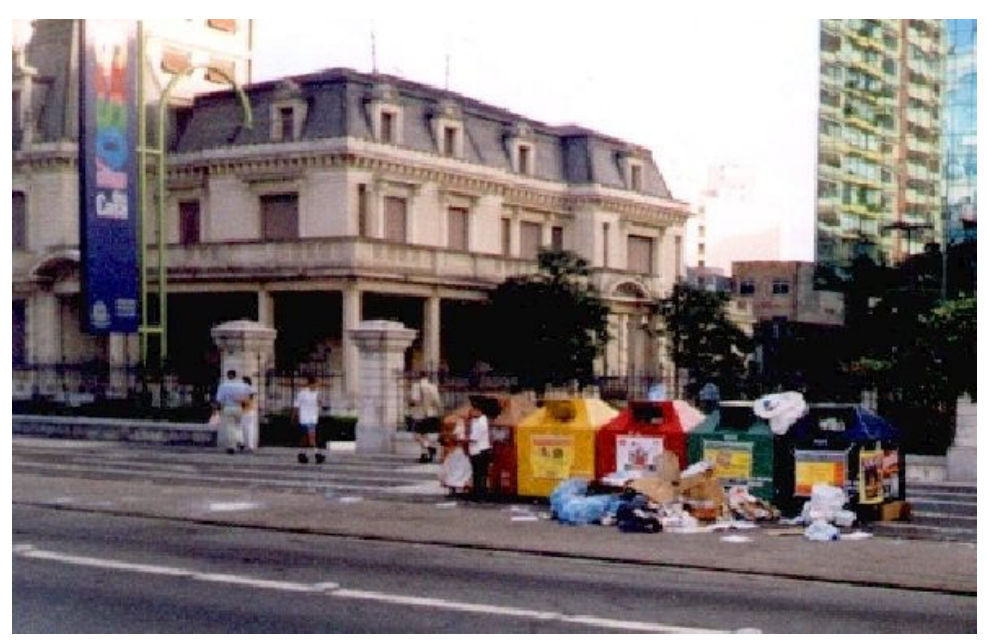

custos eram de aproximadamente US\$ 391/t comercializada, equivalentes a US\$ $294 / t$ coletada.

São José dos Campos (SP) tem, desde 1990, o programa "Luxo do Lixo" executado pela URBAM - Urbanizadora Municipal S/A. Em 1990, 12\% da população era atendida, sendo coletados 3,5 t/dia. Em 1997, 60 \% da população era atendida pela coleta seletiva (SMA 1998a). São coletadas $310 \mathrm{t} / \mathrm{mês}$, das quais $211 \mathrm{t}$ são comercializadas, sendo o restante rejeitos. São arrecadados de US\$ 14.691/mês e um custo mensal de US\$ 87.345. (ASSIS 1998).

Em Santo André (SP) o programa de coleta seletiva tem várias frentes de atuação, incluindo escolas, o paço municipal onde é coletado papel, o Bairro de Paranapiacaba. Em supermercados funciona um sistema de parceria entre a Prefeitura, a qual fornece latões e suportes para sacos plásticos, além de fazer a coleta e transporte, a ABIVIDRO -que fornece capas para os latões-, a LATASA (fornece sacos plásticos e amassadores para latas) e a FEASA - Federação das Entidades Assistenciais de Santo André, que recebe e comercializa o material. O programa é deficitário, apresentando um custo de US\$ 2.047/mes para um faturamento de US\$ 383 / mês, sendo vendidas 6 t/mês (ALBOREDA 1993b). 
A coleta seletiva de Curitiba (PR) se iniciou com a compra do lixo, pela qual população de favelas (áreas de difícil acesso) podia trocar lixo reciclável por valetransporte ou alimentos. O programa do "Lixo que não é Lixo" se iniciou em escolas, e depois se espalhou pela cidade. Houve uma maciça campanha na mídia, com criação de personagens do cartunista Ziraldo. Parcerias permitiram a redução dos custos da campanha. Os catadores se sentiram, a princípio, prejudicados, mas foram autorizados a recolher qualquer material da coleta seletiva, antes que os caminhões passassem, desde que deixassem a área limpa. Os recursos da venda do material vão para o Fundo de Assistência Social. Toda a cidade é coberta pela coleta seletiva. Os veículos utilizados são 13 caminhões baú de $35 \mathrm{~m}^{3}, 26$ motoristas e 78 coletores. Outras modalidades de "compra de lixo" como o "Câmbio Verde" foram posteriormente implantadas. Há um intenso trabalho de carrinheiros e de sucateiros; uma estimativa grosseira seria de colete de $200 \mathrm{t} /$ dia por carrinheiros. Custos (1995) $\mathrm{R} \$ 179 / \mathrm{t}$ pagos à empreiteira que faz a coleta, e o preço pago pelos materiais misturados é único de US\$14/t (OBLADEN 1995).

\subsection{Recomendações de estudos anteriores}

Alguns estudos anteriores produziram recomendações sobre a viabilização da coleta seletiva e reciclagem de resíduos sólidos domésticos. Neste item são sumarizadas recomendações encontradas em duas referências bibliográficas importantes, uma delas de caráter mais técnico e a outra de caráter mais de políticas e diretrizes gerais. $\mathrm{Na}$ discussão dos resultados dos estudos de caso, será possível avaliar a consistência entre a realidade encontrada e as recomendações.

\subsubsection{Lixo Municipal: Manual de Gerenciamento Integrado (JARDIM 1995)}

Esta é uma publicação executada em conjunto pelo IPT - Instituto de Pesquisas Tecnológicas do Estado de São Paulo e pelo CEMPRE - Compromisso 
Empresarial Para Reciclagem, uma organização governamental sem fins lucrativos formada exclusivamente por empresas.

Para conseguir o escoamento do material coletado, a publicação recomenda que se verifique se existe na região esquemas para escoamento de cada material. Também recomenda vender para várias empresas para estimular a competitividade; prefeituras deveriam fazer leilões e planejar estoques para enfrentar a sazonalidade dos preços.

Ainda segundo a publicação, a prefeitura deveria incentivar a reciclagem, implementar ações para reciclagem, consumir produtos reciclados e controlar e monitorar as quantidades coletadas e comercializadas.

Todo o sistema do programa de reciclagem deve ser planejado, estimando custos, pesquisando o mercado, contatando sucateiros e fabricantes e conhecendo a composição dos resíduos. O programa deve ainda oferecer auxílio na gestão técnica e administrativa e acompanhar o retorno dos benefícios à comunidade.

A redução de custos pode ser obtida por meio do aprimoramento da divulgação, da organização de catadores, da promoção de iniciativas espontâneas, e do uso da tecnologia melhor e mas apropriada à situação local.

\subsubsection{Agenda 21 (CNUMAD 1992)}

Os principais capítulos da Agenda 21 que apresentam recomendações específicas sobre resíduos sólidos domésticos são o Capítulo 4 - Mudança dos Padrões de Consumo - e o Capítulo 21 - Manejo Ambientalmente Saudável dos Resíduos Sólidos e Questões relacionadas com os esgotos.

No Capítulo 4, o documento ressalta a necessidade do estímulo à reciclagem, da redução do desperdício de embalagens, do estímulo à introdução de novos 
produtos ambientalmente saudáveis e da utilização de políticas de preços e instrumentos econômicos para induzir a mudança de hábitos dos consumidores.

No Capítulo 21 são enfatizados os aspectos de minimização de resíduos, maximização ambientalmente saudável do reaproveitamento e da reciclagem, a disposição e tratamento ambientalmente saudáveis dos resíduos e a ampliação do alcance dos serviços que se ocupam de resíduos. 


\section{ESTUDOS DE CASO - RESULTADOS}

Neste capítulo são expostos os resultados do trabalho de campo. São descritas características gerais dos programas estudados nos municípios de Goiânia, Campinas, Embu, Santos e Botucatu. A fim de facilitar a leitura do texto e de evitar repetições, certos detalhes foram reunidos em anexos, tais como figuras mostrando os resumos das relações interinstitucionais nos programas (Anexo 3), fluxos de material em cada programa (Anexo 4) e dados tabulares das entrevistas (Anexo 5). Os resultados de custos calculados estão no Anexo 6.

A Tabela 7.1 mostra um resumo dos tipos de entidades onde foram feitas visitas técnicas e entrevistas

Tabela 7.1. - Número de entidades entrevistadas e visitadas

\begin{tabular}{l|r|r}
\hline $\begin{array}{l}\text { Tipo de entidade / } \\
\text { instituição }\end{array}$ & $\begin{array}{l}\text { Entrevistas } \\
\text { com visitas } \\
\text { técnicas }\end{array}$ & $\begin{array}{l}\text { Somente } \\
\text { visitas } \\
\text { técnicas }\end{array}$ \\
\hline Governamental & 7 & 5 \\
Setor produtivo & 12 & 1 \\
ONG & 4 & - \\
Mista & 1 & - \\
\hline Total & 24 & 5 \\
\hline
\end{tabular}

Das entidades onde foram feitas as entrevistas, 13 não têm nos resíduos sólidos sua atividade principal, e em algumas delas o único envolvimento refere-se ao programa da qual participam direta ou indiretamente.

\subsection{Goiânia}

\subsubsection{A cidade}

Goiânia (GO) tem uma população de quase 1.000.000 de habitantes, segundo dados do IBGE (1998) da contagem de 1996. Segundo a COMURG - Companhia Urbanizadora de Goiânia - são coletadas 980 toneladas diárias de resíduos sólidos, 
que são enviadas ao aterro sanitário municipal. Uma empresa privada opera a coleta regular de resíduos domésticos e o aterro sanitário, que é um antigo lixão remediado. Os resíduos de serviços de saúde são aterrados com cal numa área especialmente reservada.

\subsubsection{A coleta seletiva}

A coleta seletiva de iniciativa da Secretaria Municipal do Meio Ambiente é incipiente, e ocorre em escolas e repartições públicas. Há parcerias com sucateiros para coleta do material; no entanto ainda são constatadas falhas operacionais, principalmente quanto à freqüência da coleta e ’a adesão das instituições geradoras de resíduos. Em alguns parques há equipamentos para coleta seletiva, entretanto os resíduos dos diversos tipos ainda são misturados nos cestos pelos usuários.

No município de Goiânia, é enfocado neste trabalho um programa de coleta seletiva implantado como um dos componentes do Projeto Meia Ponte. Esse projeto é um trabalho de desenvolvimento comunitário sustentável de iniciativa do Instituto Dom Fernando, entidade é mantida pela Sociedade Goiana de Cultura - ligada à Arquidiocese de Goiânia. Tal projeto é centrado numa usina de reciclagem de lixo, sendo os demais componentes do projeto já em funcionamento um Centro de Formação Profissional, uma Escola de Circo para crianças e adolescentes carentes e um Horto Comunitário de Plantas Medicinais. Outras unidades estão planejadas, em fase de negociação de verbas. São atendidos cinco bairros da zona leste de Goiânia: Jardim Dom Fernando I, Jardim Dom Fernando II, Jardim Aroeira I, Jardim Aroeira II e Jardim Concórdia, dos quais os dois primeiros são antigas áreas de propriedade da Igreja Católica que foram invadidas. A população residente nestes bairros é de baixa renda, e soma aproximadamente 15.000 habitantes.

O Projeto Meia Ponte recebeu esse nome porque, além de os bairros se situarem próximos ao rio Meia Ponte, faz-se referência a uma ponte simbólica, que teria uma metade construída pelo Instituto Dom Fernando, e a outra pela própria comunidade. 
Por meio de convênio com o MPAS / SAS - Ministério de Previdência e Assistência Social / Secretaria de Assistência Social, foram obtidos recursos para construção da usina de reciclagem de lixo com capacidade para 25 t/dia (trabalho em 1 turno), para geração de aproximadamente 50 empregos diretos na fase inicial do projeto, com operação em apenas um turno. Os recursos investidos no projeto estão resumidos na Tabela 7.2.

Em trabalho realizado junto à comunidade foram recrutados os integrantes da atual COOPREC- Cooperativa de Reciclagem de Lixo. A Cooperativa opera a usina, propriedade da Sociedade Goiana de Cultura, sob um contrato de comodato. Além de triar os resíduos recicláveis provenientes da coleta seletiva e da coleta regular, o núcleo fabrica telhas de papelão betumado, grânulos de polietileno reciclado e composto orgânico.

Tabela 7.2. Investimentos realizados no Projeto Meia Ponte (Goiânia - GO)

\begin{tabular}{l|r}
\hline$I T E M$ & $R \$$ \\
\hline Construção e equipamentos & 780.000 \\
Veículos & 120.000 \\
Educação Ambiental & 100.000 \\
Consultoria e terreno & 200.000 \\
\hline TOTAL & 1.200 .000 \\
\hline
\end{tabular}

Fonte: Instituto Dom Fernando

O Núcleo Industrial de Reciclagem está instalado numa área de $4.800 \mathrm{~m}^{2}$ onde há um edifício para instalações administrativas, um galpão coberto (Figura 7.1) onde são realizadas as atividades de triagem, prensagem, processamento de papel e papelão para produção das mantas de papelão, pátio de armazenamento de recicláveis, pátio de conformação e secagem das telhas, área de compostagem e lagoas de tratamento de efluentes. As áreas são razoavelmente bem organizadas, havendo ainda problemas de projeto a serem corrigidos na moega de descarga de resíduos e no processo de compostagem. Os materiais recicláveis ficam armazenados a céu aberto, organizados numa das laterais do terreno, contígua a um matagal. As telhas prontas e os grânulos plásticos são armazenados cobertos no galpão. 
Figura 7.1. Vista geral do Núcleo Industrial de Reciclagem

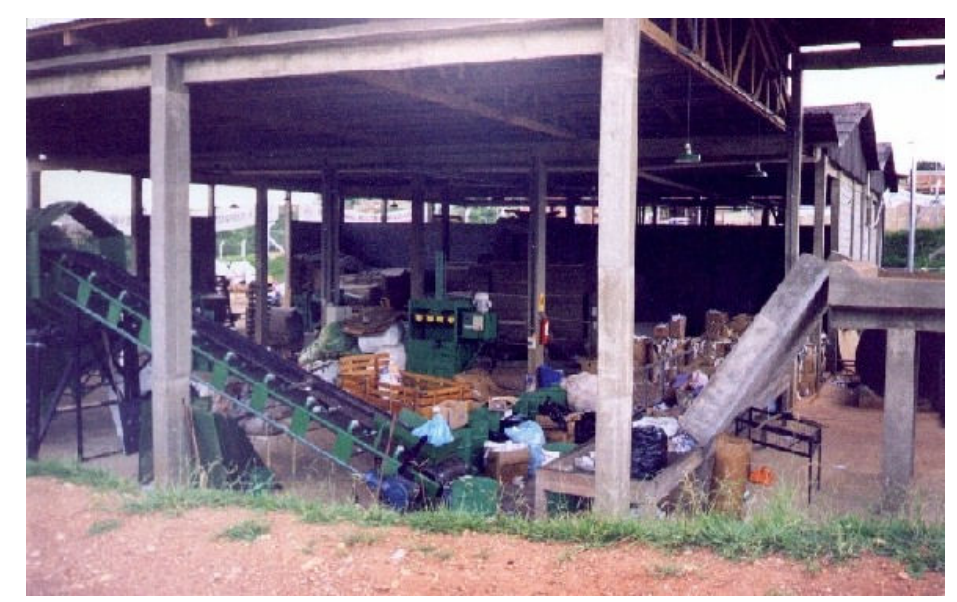

Durante a primeira visita realizada ao Núcleo, foram identificadas prováveis larvas de mosquitos em tanques do processo de plástico que continham água parada. Ao final da visita, os cooperados foram orientados a manter os tanques vazios nas paradas para manutenção, como era o caso. Em todas as visitas foi constatada também a presença de grande quantidade de moscas na área da compostagem, sendo visíveis inúmeras larvas nos montes, nas canaletas de drenagem e na lagoa anaeróbia de tratamento de efluentes. Também no prédio administrativo, que se localizava no outro extremo do terreno, havia inúmeras moscas.

Como parte de suas atividades normais a COOPREC realiza a coleta seletiva nos cinco bairros atendidos pelo programa, três vezes por semana, e realiza também a coleta regular de resíduos sólidos domésticos. Os moradores dos bairros acondicionam os resíduos em sacos plásticos, na maioria das vezes utilizando sacolas brancas tipo supermercado. À noite é coletado papelão no centro da cidade. São coletadas em média 170 t mês de resíduos, incluindo o papelão e a coleta regular. Não há controle individual do peso dos materiais coletados seletivamente. Pela estimativa efetuada durante a primeira visita, cerca de 15 t/mês são coletadas seletivamente. 
Figura 7.2. Algumas atividades do núcleo industrial de reciclagem
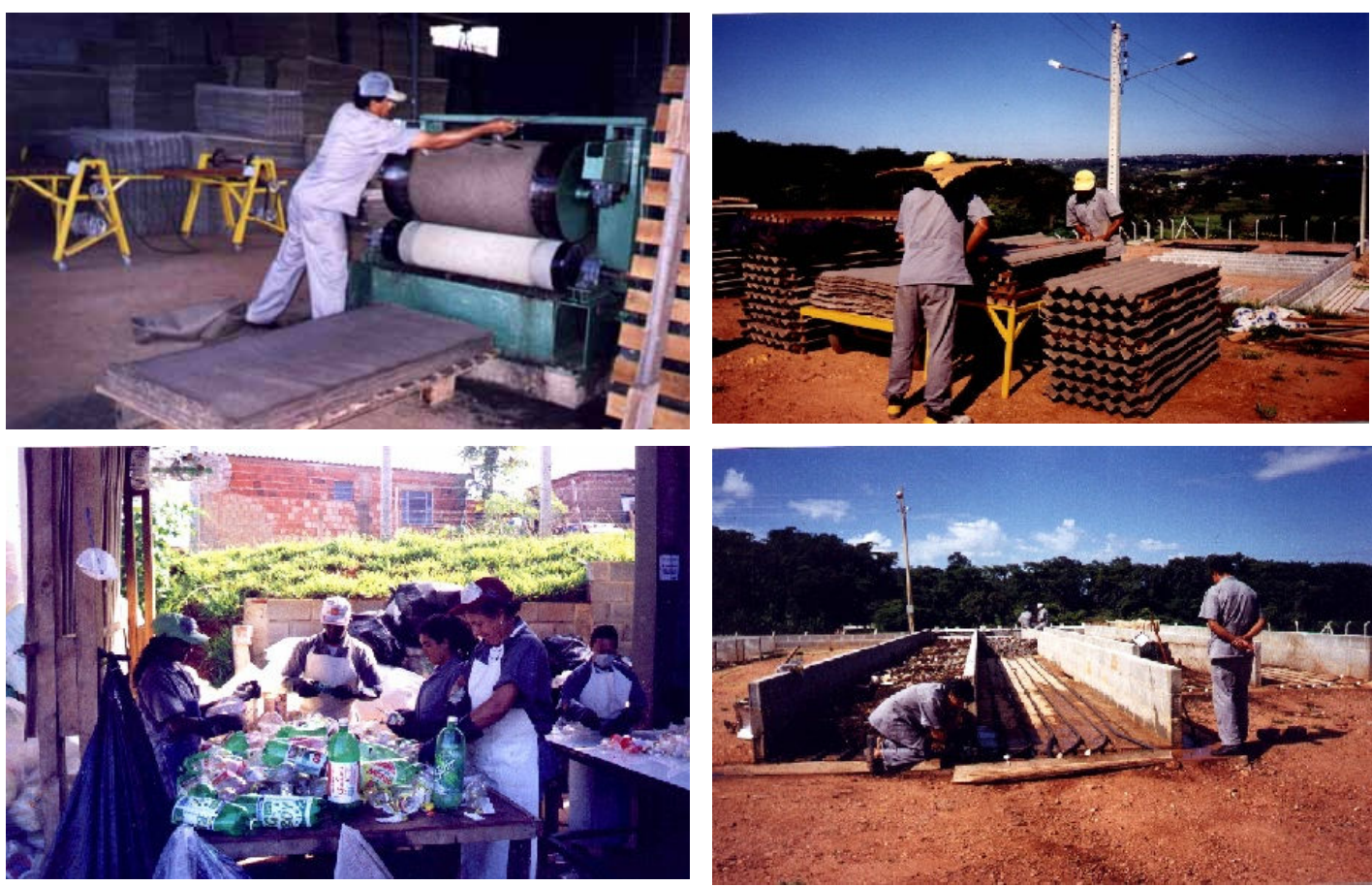

Foto superior esquerda: fabricação de cartão de fibras recicladas, superior direita: moldagem das telhas, inferior esquerda: triagem de plásticos, inferior direita: vermicompostagem

A cooperativa teve de julho a outubro de 1998 um faturamento médio de R\$ 11.682,27 e despesas de $\mathrm{R} \$ 8.197,00$. O rateio médio entre os cooperados foi entretanto de $\mathrm{R} \$ 154,00$, estando incluída neste valor a ajuda de custo prevista para a fase inicial do projeto, encerrada em outubro. Em compensação, a partir de novembro estava prevista a incorporação de rendimentos provenientes da Prefeitura Municipal por meio da COMURG - Companhia Urbanizadora de Goiânia, a qual deveria pagar $\mathrm{R} \$ 25,00 / \mathrm{t}$ pela coleta do lixo efetuada nos bairros atendidos e pelo lixo comercial coletado no centro da cidade. $\mathrm{O}$ valor por tonelada corresponde ao mesmo valor pago à empreiteira que realiza o serviço de coleta regular no restante da cidade. Não há registro ou divulgação, na COOPREC, dos custos unitários da coleta e triagem.

Segundo depoimentos dos entrevistados, a distância das principais siderúrgicas, localizadas na Região Sudeste do Brasil, reduz as possibilidades de 
venda de metais. O fechamento de pequenas fundições de alumínio diminuiu as possibilidades de ganho com o material. A sucata ferrosa deve ser comercializada obrigatoriamente com uma das duas siderúrgicas da região, que formam um cartel e ditam os preços. Também as recicladoras de plástico PET (polietilenotereftalato) estão localizadas em municípios distantes o que leva ao armazenamento do material por um período de tempo mais longo, para que possa ser completada a carga de um caminhão. Há muitas indústrias que reciclam plásticos $\mathrm{PE}$ (polietileno) na região, o que provoca uma escassez de sacos plásticos de PE. A COOPREC compra material de catadores e sucateiros para fabricar grânulos, pois não coleta material suficiente para sua produção. Essa situação foi prevista na concepção do Projeto Meia Ponte. A distância dos grandes consumidores de aparas de papel, localizados no Estado de são Paulo, também prejudica o escoamento de papéis, embora não seja impeditivo. Próximo a SP, onde estão as maiores consumidoras, a concorrência é forte, porque há muita coleta de material e os aparistas têm atuação intensa, o que mantém os preços relativamente baixos, segundo os entrevistados.

O Instituto Dom Fernando tem uma equipe de Educação Ambiental que conta com diversos profissionais, pagos com verba do projeto, que trabalham em conjunto com os cooperados para execução das atividades nos bairros atendidos e nas empresas potencialmente doadoras de material. Todos os dias alguns cooperados são destacados para palestras e atividades educativas em instituições que possivelmente poderiam doar materiais, havendo um rodízio entre os cooperados. Nas atividades são utilizadas fitas de videocassete, amostras de material reciclável e reciclado na usina, cartilhas e uma peça de teatro, encenada por atores e pelos alunos mais velhos da Escola de Circo do Projeto Meia Ponte. Na época das entrevistas, estava sendo negociada a prestação de serviços da COOPREC para um Shopping Center da cidade.

\subsubsection{As Parcerias}

A parceria entre a SGC/IDF e a comunidade permite aos moradores auferir renda, ao mesmo tempo em que promovem melhoria das condições ambientais no 
bairro. Segundo os entrevistados, isto teria pouca possibilidade de ocorrer, ao menos no curto prazo, sem a ação de incentivo e organização da SGC/IDF, que colocou profissionais à disposição da comunidade para a elaboração do projeto. $\mathrm{O}$ contrato de comodato entre a SGC e a COOPREC serve de guia fundamental para a parceria.

Por seu lado, O MPAS/SAS tem interesse em aplicar as verbas em obras sociais, e a parceria com o setor não governamental permite um gerenciamento adequado dos recursos pela entidade que concebe e executa o projeto. Outros apoios importantes vêm do SEBRAE, SENAI e outras instituições. Já as relações com os sucateiros e industriais estabelecidos na região são puramente comerciais, não havendo nenhum tipo especial de compromisso ou apoio.

A relação entre a SGC e a SANOESTE teve muitos problemas. A SANOESTE, vencedora da licitação da construção da usina e fornecimento dos equipamentos, falhou no projeto e na especificação de certos equipamentos que deveriam ser cobertos pelo período de garantia. A COOPREC chegou a adquirir com recursos próprios um aglutinador maior que o originalmente fornecido pela SANOESTE para a unidade de plásticos - o original estava subdimensionado. Por outro lado, a SGC aceitou prematuramente a entrega dos equipamentos, por motivos burocráticos da origem federal da verba, comprometendo a cobrança das correções junto à SANOESTE. Isto causou atrasos na entrada em marcha da usina. Após aproximadamente um ano da conclusão das obras a maioria das dificuldades mais graves foi sanada, embora ainda haja melhorias a executar e defeitos de projeto a corrigir.

\subsection{CAMPINAS}

\subsubsection{A Cidade}

Campinas está localizada a aproximadamente $90 \mathrm{~km}$ de São Paulo e abriga cerca de 980.000 habitantes, segundo a contagem de população de 1996 do IBGE (1998). É o centro de uma região com características de metropolização que sofre 
com os problemas do crescimento urbano acelerado e desordenado. São coletados aproximadamente 800 t/dia de resíduos domésticos. A maior parte dos resíduos sólidos do município é destinado ao Aterro Sanitário Delta-A. A CETESB atribuiu à área de disposição final do município a classificação "condições controladas" (SMA 198). $\mathrm{Na}$ área do aterro há catadores que se pretende integrar a novas formas de coleta seletiva e triagem previstas pela administração municipal.

O entulho de construção civil é utilizado para aterro de áreas cadastradas pela prefeitura municipal. Os resíduos de serviços de saúde são atualmente aterrados, havendo a previsão de tratamento por microondas. $\mathrm{Na}$ área do aterro sanitário está prevista também a instalação de uma usina de compostagem.

\subsubsection{A Coleta Seletiva}

A Lei 6.901 de 07 de janeiro de 1992 autorizou o executivo a criar o programa de coleta seletiva e reciclagem de lixo em Campinas. A mesma lei determina a inclusão de verba no orçamento municipal para a execução do programa e que a renda com a venda dos materiais seja revertida para o Fundo Social de Solidariedade de Campinas (CAMPINAS 1992), para usos específicos. O Departamento de Limpeza Urbana - DLU é o responsável pela operação da coleta. São utilizados veículos e funcionários próprios para a coleta.

Mais recentemente, a lei 9.917 de 26 de novembro de 1998 criou o “Programa Municipal de Material Reciclável em Favelas, Núcleos Habitacionais e Áreas de Assentamento". Nas áreas pertencentes ao programa e onde não haja coleta seletiva pelo DLU, fica autorizada a coleta de materiais recicláveis por agentes de “Unidades Regionais" credenciadas (CAMPINAS 1998).

No contexto geral do município há uma série de ações de melhoria de gerenciamento dos resíduos sólidos domésticos planejadas, tendo sido um dos motores da ação a epidemia de dengue ocorrida nos anos recentes. 
A coleta seletiva domiciliar porta-a-porta atende 200 bairros, correspondendo a 1/3 dos bairros do município e metade da população, com freqüência semanal. A população acondiciona os resíduos em sacos plásticos, geralmente sacolas tipo supermercado. Caminhões compactadores circulam nos bairros e a coleta é feita pelos por funcionários do DLU (Figura 7.3a). A coleta seletiva em comunidades organizadas atende cerca de 420 estabelecimentos como escolas, associações de bairros, condomínios, repartições públicas, e outras, com freqüência também semanal. O DLU cede tambores metálicos de 200 litros pintados para o acondicionamento dos resíduos (Figura 7.3c). Locais de Entrega Voluntária estão instalados em 14 pontos estratégicos do município, onde há contêineres compartimentados (Figura 7.3b). Os contêineres são trocados diariamente.

Figura 7.3. Algumas Atividades da Coleta Seletiva em Campinas
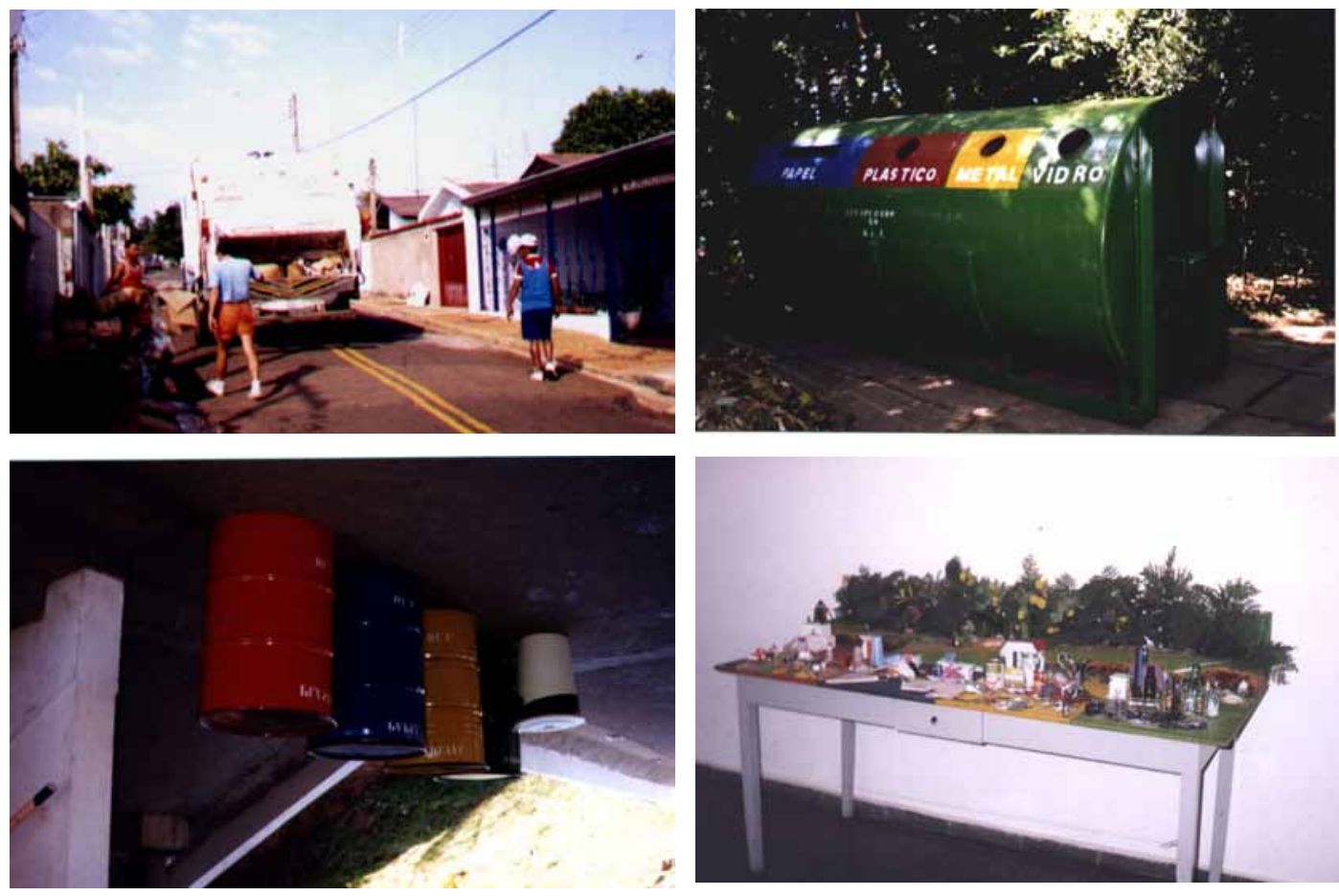

(a) superior esquerda: coleta seletiva porta-a-porta; (b) superior direita: posto de entrega voluntária;

(c) inferior esquerda: coleta em comunidades organizadas; (d) inferior direita: material para atividades educacionais do "Lixo Tour". 
A central de triagem ocupa uma área de $3.495 \mathrm{~m}^{2}$, dos quais 3.100 são pátio de descarga, armazenamento e estacionamento de veículos, e o restante é ocupado pelo galpão de triagem escritório e vestiários. No mesmo local existem ainda outros escritórios do Departamento de Limpeza Urbana. Estão instalados uma esteira de triagem, duas prensas verticais e uma prensa horizontal. Há carrinhos diversos para transporte interno dos materiais.

O conjunto da usina não tem capacidade para triar todos os resíduos coletados seletivamente, por isso uma parte é vendida em bruto. Com a redução do efetivo por aposentadorias e demissões, vinha ocorrendo falta de pessoal do DLU para coleta seletiva e triagem, prejudicando inclusive o atendimento a alguns bairros e à coleta em comunidades organizadas dispostas a segregar os resíduos. Em 1998 houve uma parada geral da usina para reforma da esteira e outros equipamentos, e por falta de recursos operacionais no DLU e por falta de mercado para o material sem triar, somente $40 \%$ do material coletado foi comercializado. Uma parte do material foi doado a antigos catadores do complexo Delta, que foram instalados provisoriamente fora da envoltória para que tivessem condições sanitárias melhores.

Após a reforma da esteira, foi retomada a operação de triagem, utilizando mão-de-obra de presidiários que desfrutam de regime semi-aberto. Eles recebem um salário mínimo e têm sua pena reduzida em um dia para cada três trabalhados. Atualmente há um maior número de empresários interessados em adquirir os resíduos não triados, um deles inclusive instalou uma usina de triagem dentro da área do presídio Ataliba Nogueira, e a coleta seletiva não tem sido suficiente para abastecê-lo.

O envolvimento de empresários é reflexo da descentralização da triagem como diretriz que vem sendo seguida. Por isso novas unidades de triagem vêm sendo montadas, e a Secretaria Municipal de Saúde tem acompanhado esse desenvolvimento no que concerne às condições sanitárias das novas unidades. 
O custo divulgado do programa de coleta seletiva é de $\mathrm{R} \$ 245 / \mathrm{t}$ coletada, inclusive triagem. O valor dos equipamentos, incluindo veículos, esteiras, prensas, carrinhos, contêineres para entrega voluntária e comunidades organizadas, entre outros, é da ordem de R\$ 1.979.000 (CARDOSO e TERENTIN 1998). Este valor não foi efetivamente desembolsado quando da implantação do programa porque vários equipamentos, principalmente veículos, foram transferidos já usados de outros serviços municipais.

A Educação Ambiental com foco na coleta seletiva é feita por funcionários do DLU. Na usina há uma sala de aula com material didático montado pelo próprio departamento (Figura 7.3d). São feitas palestras em escolas e nas instalações do departamento, em visitas guiadas chamadas Lixo Tour. Material didático gráfico é obtido, entre outras formas, por meio de parcerias com empresas. São distribuídos folhetos informativos nos bairros de maneira esporádica.

\subsubsection{As parcerias}

A relação entre o DLU e o FUSSCAMP é a parceria central deste programa. Entretanto, face às dificuldades operacionais que o DLU vinha enfrentando para executar a triagem, ganharam destaque as parcerias com as unidades descentralizadas, tais como a instalada no presídio Ataliba Nogueira. Neste caso, o convênio consiste no oferecimento de trabalho para os presidiários que estão em regime semi-aberto. Os presidiários trabalham na triagem e recebem um salário mínimo, pago a suas famílias, além de terem a pena reduzida em um dia a cada três trabalhados. O DLU, por seu lado, reduz o custo unitário da triagem realizada em sua usina.

A nova legislação autoriza o funcionamento de coletas particulares, em especial as cooperativas, nas áreas não atendidas pelo DLU. Isto deve, segundo depoimentos, consolidar ainda mais a política de descentralização da triagem, e pode gerar novas parcerias. 
Apoios recebidos de empresas também se destacam. Entre elas a TETRA PAK, que em virtude de sua política ambiental, incentiva a coleta seletiva e reciclagem das embalagens que produz, mas não tem interesse em realizar ela mesma tal operação. A distribuição de material educativo que a empresa faz às prefeituras, inclusive para Campinas, procura esclarecer que a embalagem longa vida é reciclável, e busca incentivar a segregação deste componente dos resíduos. As empresas parceiras Padreca, do ramo de sucatas e desenvolvimento de soluções para resíduos, e Biagioni, do ramo de papel e papelão, investiram em equipamentos e tecnologia para aproveitamento das fibras, e oferecem uma opção para a reciclagem destas embalagens, e têm adquirido o material a preço simbólico de alguns programas de coleta seletiva, entre eles o de Campinas. A UNESP - Universidade Estadual Paulista / Faculdade de Ciências Agronômicas - desenvolveu processo para reciclagem do plástico contido nas embalagens longa vida, e também tem portanto um papel importante no desenvolvimento tecnológico.

\subsection{Embu}

\subsubsection{A cidade}

A Estância Turística de Embu das Artes está localizada na Região Metropolitana de São Paulo. É famosa pelo seu artesanato e pela produção de móveis rústicos. Nos últimos anos a cidade tem tido a função também de cidade-dormitório, o que pode ser verificado, entre outras formas, pelas inúmeras linhas de ônibus e lotação que fazem o transporte de passageiros principalmente para as regiões de Pinheiros e Santo Amaro. Há algumas indústrias instaladas no município; entre elas a RIPASA S/A, presente na área central da cidade com uma unidade de produção de cartão para embalagens. Boa parte do município está em área de proteção de mananciais, o que o torna um dos envolvidos no Programa de Despoluição da Bacia Guarapiranga. 
Segundo o IBGE (1991), a população do município é de cerca de 195.000 habitantes. São gerados em torno de 130 t/dia de resíduos sólidos domésticos. A maior parte dos resíduos é destinada ao aterro controlado, que vem sendo remediado e transformado num aterro sanitário com recursos do Programa Guarapiranga.

\subsubsection{A coleta seletiva}

A Prefeitura Municipal iniciou em 1994 um trabalho de recuperação do lixão da cidade, onde moravam catadores que exerciam a atividade de separação de materiais reaproveitáveis. A retirada dos moradores fazia parte dos trabalhos de remediação do lixão, providência inserida no Programa Guarapiranga. Atualmente os catadores não moram mais no lixão. Parte deles, juntamente com novos catadores integrados ao grupo, formam hoje a COOPERMAPE - Cooperativa de Reciclagem de Matéria-Prima de Embu, formada por incentivo e com apoio da Prefeitura Municipal.

O programa atua através de coleta porta-a-porta que atende aproximadamente 87.000 pessoas (CEMPRE 1999), coleta em pontos comerciais e industriais doadores e de entrega voluntária na central de triagem; neste caso o material é trocado por mudas do viveiro municipal que funciona no mesmo terreno.

A coleta porta-a-porta é realizada nos bairros com freqüência semanal em cada bairro atendido (Figura 7.4c). A população acondiciona os resíduos em sacos plásticos tipo supermercado ou em caixas de papelão. Para retirada de móveis, eletrodomésticos volumosos e de grandes quantidades de resíduos, permite-se às vezes a entrada dos coletores nas residências. A aproximação do caminhão é anunciada por meio de um sino ou por meio de uma gravação do som do sino em fita cassete.

São utilizados dois caminhões de propriedade da prefeitura, dos quais um deles, com mais de dez anos de uso, tem constantes problemas de manutenção. Até meados de 1998 era utilizado um terceiro caminhão, este com carroceria aberta, 
alugado para executar retiradas especiais em indústrias, comércio e residências. Por causa das freqüentes quebras de um dos caminhões-baú (Figura 7.4d), o terceiro caminhão executava também serviço de coleta porta-a-porta dos bairros. Esse veículo foi retirado do serviço por contenção de despesas por parte da Administração Municipal. Os dados de custos e operacionais fornecidos compreendem o período em que tal veículo ainda era utilizado.

A central de triagem conta com poucos equipamentos e instalações: uma balança pequena usada, doada como sucata, uma copa que funciona como sala de reuniões, sanitários, vestiários e uma pequena sala para guarda de materiais nobres. Um triturador de vidro foi doado pela CISPER mas não foi instalado por falta de possibilidade de instalação elétrica na área devido a débito da Prefeitura Municipal com a Companhia Elétrica. A triagem é feita manualmente (Figura 7.4a)

Figura 7.4. A coleta seletiva em Embu
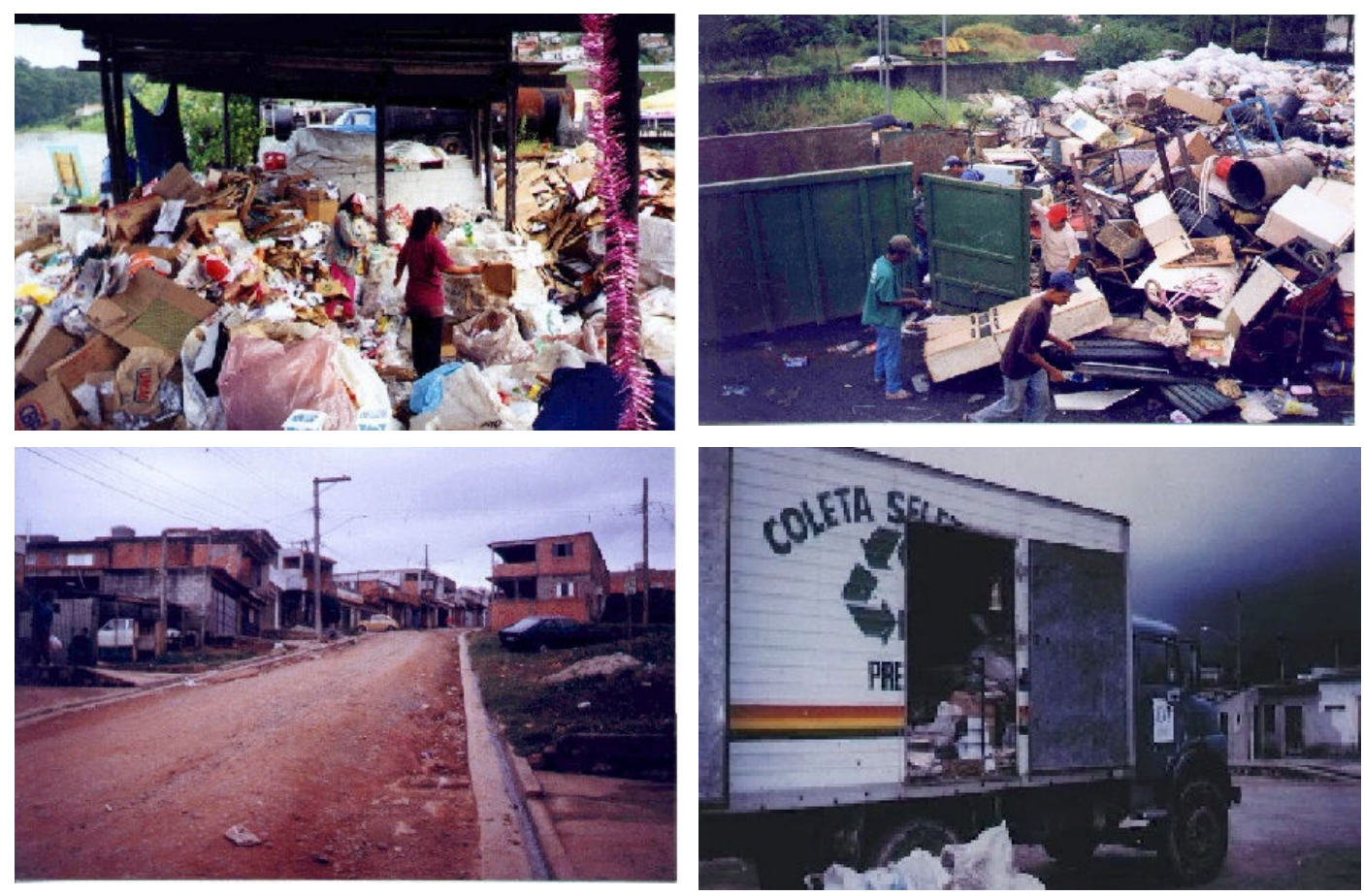

(a) Acima à esquerda: cooperadas na área de triagem; (b) acima à direita: cooperados na área de armazenamento de sucata metálica; (c) abaixo à esquerda: um dos bairros atendidos pela coleta seletiva; (d) abaixo à direita: um dos caminhões utilizados na coleta 
Durante visita realizada à central de triagem foram identificadas prováveis larvas de mosquitos num pneu e também a movimentação diurna de roedores em meio a materiais empilhados a céu aberto. Feito o alerta, houve melhoria da organização dos materiais.

Já há verba disponível para a construção de uma nova central de triagem, a ser localizada na área do aterro sanitário. Nesta área será possível a instalação de equipamentos, como prensa, moedor de vidro e outros. Também será possível contar com a balança do aterro para melhorar o controle das quantidades do material.

Papelão e sucata metálica são armazenados em caçambas de propriedade dos sucateiros compradores (Figura 7.4b). As embalagens longa vida não são separadas porque não há compradores interessados. Quase todo o material é armazenado a céu aberto, com exceção são dos papéis separados para a RIPASA. Nenhum material é prensado, todos são vendidos soltos.

Os compradores de materiais entrevistados mostraram que as quantidades compradas da cooperativa são pequenas em relação ao seu movimento total, variando de 1 a $5 \%$ do movimento específico de cada material ou de 0,3 a 2,5\% da matériaprima comprada.

Segundo BENSEN (1998) a coleta seletiva custa para a Prefeitura Municipal US\$ 141,20 / t . São coletados mensalmente 72 t de resíduos recicláveis, dos quais 60 toneladas são vendidos, sendo o restante rejeitos enviados ao aterro sanitário. Esse programa tem representado importante fonte de investimentos em meio ambiente no município, inclusive para recuperação do antigo lixão, transformado em aterro sanitário, e para coleta seletiva.

O PEACE - Programa de Educação Ambiental e Cidadania de Embu visa trabalhar Educação como um todo, entre os temas tratados com os grupos estão os 
resíduos sólidos. Há divulgação de folhetos e reuniões com a comunidade. Acompanhando o serviço no dia-a-dia, nota-se que algumas escolas entregam para a coleta seletiva apenas o papelão proveniente das embalagens utilizadas na cantina. Em uma das escolas visitadas havia contribuições de plástico, alumínio e outros, separados em tambores.

\subsubsection{As parcerias}

A parceria central ocorre entre a Prefeitura Municipal e os catadores. Ao dar apoio na obtenção de documentos, na formalização da cooperativa, na articulação de empréstimo da Secretaria do Bem-Estar Social para compra de equipamentos e materiais e na formalização da cooperativa, a Prefeitura consegue executar a coleta seletiva a um custo aceitável, com envolvimento da população, ao mesmo tempo que os catadores trabalham em condições bem melhores. Trata-se de uma cooperativa incentivada por um agente externo.

A Prefeitura Municipal também buscou apoios para o desenvolvimento dos cooperados como profissionais: alfabetização, informática, cooperativismo, entre outros. Foram obtidos apoios da FETRABALHO, do SEBRAE, da ACISE Associação do Comércio, Indústria e Serviços de Embu, entre outros. Os cooperados fazem a comercialização dos materiais, e a equipe da Prefeitura dá apoio na contabilidade e administração. Segundo depoimento de um dos compradores de material, seria de se esperar, pelo tempo decorrido do programa, uma maior autonomia e uma postura comercialmente mais madura da cooperativa. Neste sentido, consegue ações que a longo prazo devem contribuir para a administração da cooperativa se tornar cada vez mais independente.

Com a interveniência da Prefeitura Municipal, a cooperação da RIPASA se revela uma importante sustentação do programa, já que $47 \%$ do faturamento da Cooperativa é proveniente do papel vendido a essa indústria. Para a empresa o custo do tratamento diferenciado dado à cooperativa como fornecedora é desprezível, e o 
benefício é o bom relacionamento com a comunidade e a melhoria na qualidade de vida da cidade que a abriga.

Com o sucateiro que compra o material metálico há uma parceria comercial e operacional. O depósito paga à cooperativa o mesmo que paga a depósitos menores, havendo portanto a eliminação de um intermediário em relação à situação anterior dos catadores. O fornecimento da caçamba pelo depósito facilita a operação de ambas as partes, já que o material fica mais organizado enquanto em poder da cooperativa e o depósito não tem o trabalho de triar e carregar a caçamba e economiza espaço.

\subsection{SANTOS}

\subsubsection{A cidade e o gerenciamento de resíduos sólidos}

Santos, localizada no Litoral do Estado de São Paulo, tem aproximadamente 412.000 habitantes segundo a contagem de população de 1996 (IBGE 1998). A maior parte do município está localizada no continente, onde se localizam principalmente áreas de preservação ambiental. Do total da população, 99,6 \% vive na região insular. As atividades econômicas predominantes são o turismo (20\% das residências não são permanentemente habitadas), o comércio e a atividade portuária.

Dos resíduos domésticos, 400 t/dia são destinados ao Aterro de Alemoa, local de disposição considerado em condições inadequadas (CETESB 1998), que ora se encontra em início de processo de melhoramento. Até março de 1998 a coleta regular de lixo era realizada pela PRODESAN - Progresso e Desenvolvimento de Santos S/A., empresa de capital misto. A partir de abril daquele ano a empresa TERRACOM passou a executar a coleta, em regime de operação contratada com pagamento por serviços prestados. 
Santos é um dos municípios brasileiros que trabalha sob a perspectiva da construção da Agenda 21 Local, estando várias instituições envolvidas neste trabalho.

\subsubsection{A coleta seletiva}

Em 1990 foi formado um grupo com representantes de secretarias municipais e da PRODESAN para implantação de um piloto de coleta seletiva. Desde então foi planejada e executada a participação de pacientes ex-internos de atendimento psiquiátrico e dos carrinheiros nas atividades de coleta seletiva e triagem realizadas pela PRODESAN. Para implantação do piloto nos bairros, foram feitas reuniões e atividades de sensibilização com pessoas da comunidade e em escolas. Foi desenvolvido um intenso trabalho junto à Associação dos Carrinheiros de Santos, instalada em galpão oferecido pela Prefeitura.

Posteriormente foi adicionado ao programa o componente trabalhadores ecológicos, que eram dez carrinheiros selecionados para atender o bairro do Macuco, onde a PRODESAN não fazia a coleta porta-a-porta, deixando todo o trabalho para eles. Os trabalhadores recebiam uma ajuda de custo mensal de $\mathrm{R} \$ 180,00$. Esse componente foi desativado recentemente por falta de verba, e os trabalhadores deslocados para o Centro de Triagem, onde trabalham junto com os ex-internos dos serviços de Saúde Mental.

Segundo depoimento, atualmente o Programa Lixo Limpo atende a cerca de $80 \%$ da população da cidade e coleta cerca de 178 t/mês. A coleta seletiva é executada pela TERRACOM, com pessoal próprio, utilizando-se caminhões de carroceria alterada da PRODESAN, mediante contrato de comodato. Cada roteiro de coleta é atendido uma vez por semana. A população acondiciona os resíduos geralmente em sacos plásticos tipo supermercado. 
Figura 7.5. Galpão de triagem da PRODESAN

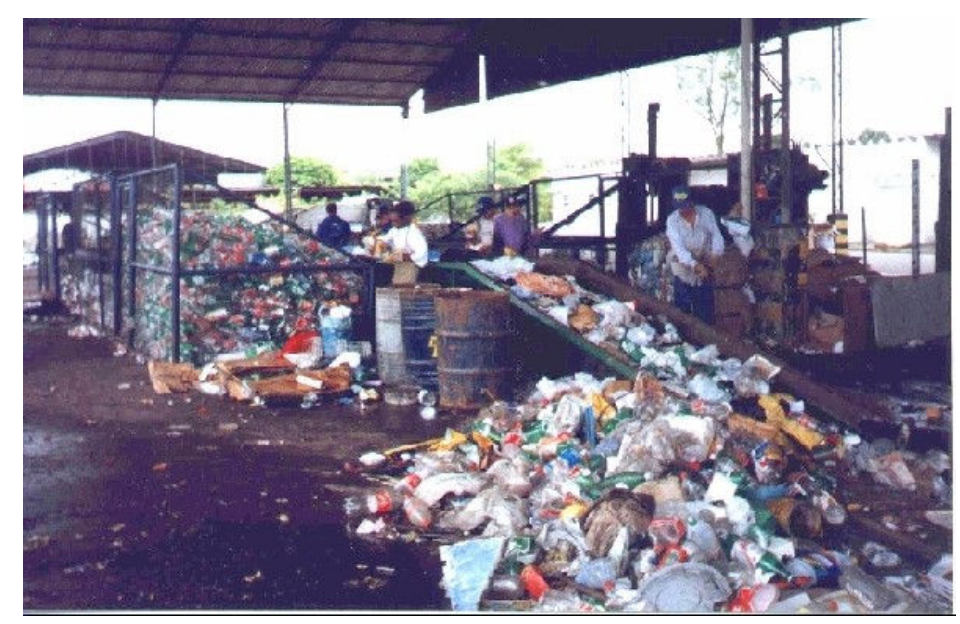

A triagem é feita numa área da PRODESAN anexa à usina de asfalto, (Figura 7.5) utilizando-se mão-de-obra de ex-internos do Serviço de Saúde Mental e de extrabalhadores ecológicos. Está sendo analisada a possibilidade de privatização do serviço de triagem. Na nova situação seriam reservadas algumas vagas para exinternos. A usina de triagem recebe ainda diariamente um caminhão de lixo de coleta seletiva de São Vicente (1.200 a 1.600 kg cada caminhão).

Muitos materiais que antigamente eram comprados por sucateiros atualmente não têm mais interessados e são considerados rejeitos, entre eles: sacos plásticos, embalagens flexíveis de alumínio, chapas radiográficas e isopor.

Centenas de carrinheiros circulam pela cidade coletando materiais recicláveis. A prefeitura cadastra os carrinheiros, num máximo de 250, número considerado limite pela prefeitura. Sem o cadastramento, a CET - Companhia de Engenharia de Tráfego apreende os carrinhos. A circulação dos carrinheiros é limitada, nas principais vias, ao horário noturno. Não há dados atualizados, nos registros da administração municipal, sobre a quantidade de material coletada pelos carrinheiros.

O trabalho de coleta porta-a-porta e dos PEVs é realizado pela TERRACOM pelo preço de R $\$ 295$ / t. Segundo dados da PRODESAN, o preço da coleta seletiva 
Figura 7.6. Sede da Associação dos Carrinheiros de Santos

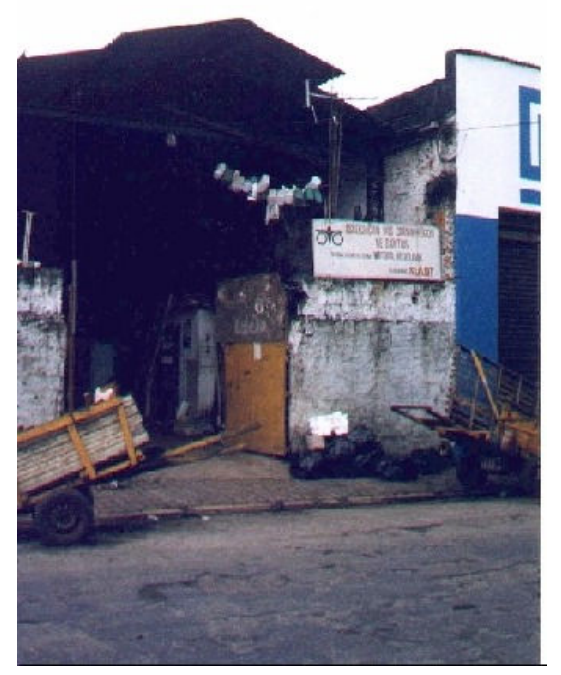

cobrado da Prefeitura Municipal em fevereiro de 1997 era de R\$335,31/t e o preço da triagem dos recicláveis era de $\mathrm{R} \$ 110,33$ / t.

A coleta seletiva é divulgada por meio de folhetos nos quais são informados os dias da semana de coleta em cada bairro. São feitas palestras e atividades também em escolas. Está sendo prevista a formação de pessoas na terceira idade para trabalharem como multiplicadores para melhorar a adesão da população ao programa.

\subsubsection{As parcerias}

O programa encontra-se claramente numa fase de transição em que o modelo de gestão está sendo modificado.

No modelo anterior as parcerias centrais neste município envolviam vários órgãos municipais (Secretaria do Meio Ambiente, Secretaria da Saúde, Secretaria de Ação Comunitária) e a PRODESAN e havia bastante assistência para os carrinheiros. 
No novo modelo, tem havido pouco contato da Secretaria de Desenvolvimento Urbano e Ambiental - Diretoria de Meio Ambiente (sucessora da antiga Secretaria de Meio Ambiente) e a parceria com a Secretaria de Saúde tende a reduzir significativamente seu impacto, caso se confirme a privatização da triagem. A Secretaria da Saúde diz que a falta de verba para pagamento de salários não é sistemática, mas provoca dificuldades importantes com os pacientes em recuperação, desestabilizando todo o sistema. Também informa que desligando-se da coleta seletiva, pode deslocar os usuários para outros.

\subsection{BOTUCATU}

\subsubsection{A Cidade}

A cidade de Botucatu, com aproximadamente 100.000 habitantes segundo a contagem de população de 1996 (IBGE 1998) está localizada a cerca de 230 km São Paulo. Na cidade circulam muitos estudantes, por causa do Campus da UNESP, e moradores de outros municípios que buscam os serviços do Hospital Universitário. Neste município, a principal atividade econômica é a agricultura, principalmente o café. Há também algumas indústrias de porte instaladas na cidade.

Os resíduos sólidos domésticos são coletados por uma empresa particular. Não há controle de pesagem dos resíduos sólidos coletados pelo serviço municipal executado por empreiteira, pois não há balança rodoviária no aterro e não se faz uso regular de balança disponível em uma indústria da região. São coletados diariamente uma média de 67 t de resíduos sólidos domésticos no município. A Secretaria Municipal do Meio Ambiente avalia, entretanto, que uma quantidade significativa dos resíduos sólidos domésticos ainda deixa de ser coletada.

O aterro sanitário foi avaliado pela CETESB como estando em condições adequadas, embora na visita técnica tenham sido constatadas falhas de vazamento de chorume para fora das células. Os resíduos dos Serviços de Saúde são incinerados no 
equipamento da UNESP, que é um equipamento antigo que precisa de reforma urgente.

\subsubsection{A coleta seletiva}

Não há coleta seletiva implantada pela prefeitura no município. Um projeto apresentado pela UNESP em conjunto com a Ação da Cidadania de Botucatu não teve o apoio da Administração Municipal. Está sendo cogitada a instalação de uma usina de triagem na área do aterro. Esporadicamente é realizada a "Operação Faxina", para coleta de materiais de grandes volumes como móveis velhos e pneus além de garrafas e outros. $\mathrm{Na}$ operação mais recente foram coletadas aproximadamente 100 toneladas, das quais aproximadamente $30 \%$ foram encaminhadas para reciclagem. A Secretaria Municipal de Meio Ambiente está articulando um programa amplo de Educação Ambiental que pode culminar com a implantação da coleta seletiva na cidade no médio ou longo prazo.

A UNESP, por oferecer serviços de saúde no seu Hospital das Clínicas e por ter laboratórios, tem tido cuidados especiais com seus resíduos e está implantando diversas melhorias no seu gerenciamento. Está prevista a reforma do incinerador, entre outras ações. Destas, destacam-se aqui dois programas de coleta seletiva na instituição.

Um deles é o Programa de Reciclagem de Papel da Faculdade de Medicina. Esse programa estava previsto, mas não implantado, desde 1994. Em 1998 foi reformulado, entre outros motivos pela necessidade legal de adequação da destinação do Hospital Universitário como um todo. Ainda não se definiu o destino
Figura 7.7. Um dos espaços utilizados para armazenamento de papel para reciclagem no Campus Rubião

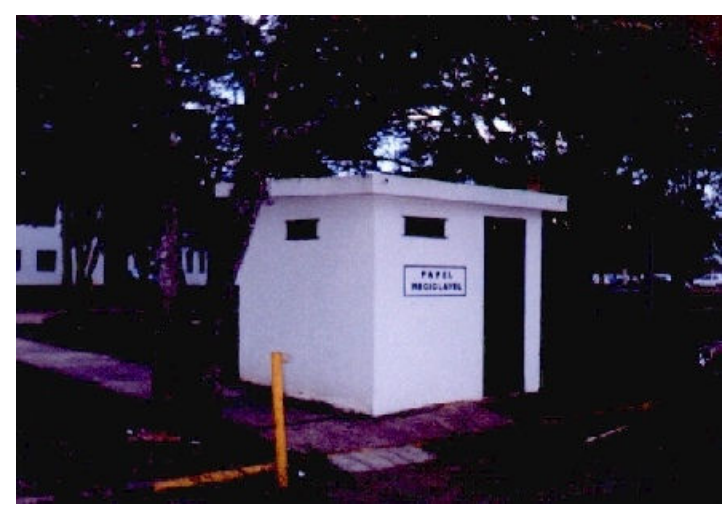


do dinheiro arrecadado com a venda do material. A coleta é realizada nos escritórios, onde estão instaladas caixas de papelão com a sinalização da coleta seletiva. Coletase aproximadamente uma tonelada por semana de papel e papelão, que são armazenados em espaços ociosos (Figura 7.7). A coleta é feita pela empresa limpadora sem alteração no contrato (em relação ao sistema anterior, sem segregação), e o material armazenado em salas existentes e vagas. Está prevista a implantação do mesmo programa no Instituto de Biociências. No âmbito deste programa foi produzido um vídeo, por pessoal próprio da Faculdade, para divulgação do programa, abordando as questões ambientais que envolvem o papel, o desperdício e a coleta seletiva na Faculdade. Todo o material gráfico para conscientização dos funcionários com relação ao gerenciamento de resíduos está sendo patrocinado por fornecedores.

Outra proposta, em funcionamento desde 1998, foi implantada pelo Departamento de Ciências Ambientais da Faculdade de Ciências Agronômicas. Inicialmente a coleta seletiva funcionou com dois locais de entrega voluntária, sendo um na entrada do Campus Lageado (Figura 7.8) e outro próximo ao Hospital Universitário no Campus Rubião, esse desativado recentemente. Estava localizado num ponto de grande circulação, mas foi retirado porque estavam ocorrendo problemas operacionais (roubo de metais, transbordamento de papéis e depósito de resíduos não recicláveis nas caçambas). Os contêineres foram adquiridos com verba

Figura 7.8. Posto de Entrega Voluntária - Campus Lageado

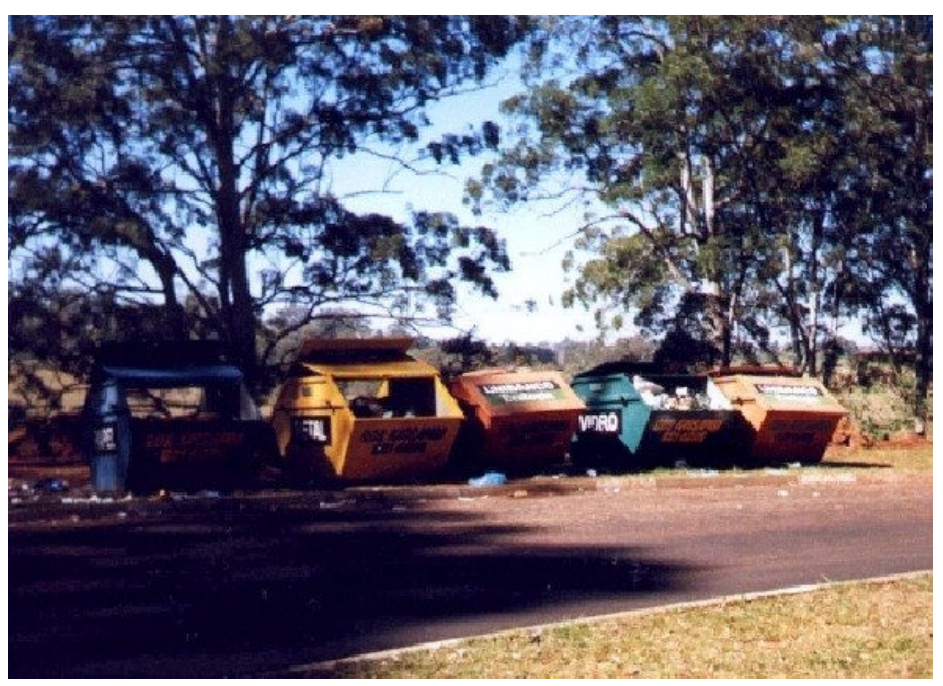


de R\$ 15.000,00 obtida do UNIBANCO Ecologia. A parte que restou do investimento ainda paga algumas despesas operacionais como o transporte do material.

Anteriormente à implantação operacional do programa foi feita a caracterização dos resíduos da Faculdade, que mostrou que dos $30 \mathrm{~kg}$ de lixo gerados em média por dia de trabalho, $61 \%$ eram constituídos por papel. Na época em que foi feita a caracterização dos resíduos, houve certa resistência em alguns departamentos, inclusive quando da caracterização dos resíduos, devido ao medo de divulgação de informações encontradas nos documentos desprezados. Atualmente o papel coletado na diretoria é destruído.

No edifício da Administração do Campus Rubião e no edifício da Diretoria da Faculdade de Ciências Agronômicas, além da coleta seletiva de papéis, há também a coleta de copos plásticos descartáveis, sendo estes últimos coletados em contêineres especiais e levados ao Departamento de Ciências Ambientais para processamento.

A atividade de desenvolvimento de tecnologia de reciclagem é intensa no departamento, havendo contatos e parcerias com diversas empresas. Estão instalados equipamentos de porte industrial para lavagem, moagem e injeção de termoplásticos, e vêm sendo produzidas peças regularmente. São processados os plásticos coletados nos PEVs, os copos descartáveis utilizados na Diretoria e os plásticos provenientes da cidade de São Manuel, vizinha a Botucatu. Os projetos são integrados, o que permite intercâmbio de equipamentos entre projetos. Há também a preocupação de tornar os equipamentos rentáveis, de forma que haja sustentação financeira para a continuidade dos projetos. Em função disso, algumas peças fabricadas nestes equipamentos, como caixas de filmes fotográficos, podem ser vendidas. Já foram produzidas também réguas e tubos para canetas esferográficas, para brindes. PET moído também é vendido. A soma dos plásticos comercializados está em torno de 8,6 t/mês. 
Também são feitos trabalhos de desenvolvimento em compostagem, sem relação com a coleta seletiva. $\mathrm{Na}$ área da compostagem foram identificadas prováveis larvas de mosquitos na água empoçada sobre um saco plástico cheio de rejeitos.

Os metais são levados dos PEVs por agentes informais, de forma que praticamente não se acumula quantidade suficiente para vender. O único registro, disponível, da primeira leva vendida, dá conta de que foram $264 \mathrm{~kg}$ de material metálico vendido. Os vidros não encontram mercado, e por isso também não são vendidos e não há controle. Os plásticos reciclados também não são pesados, de forma que o único controle existente é o dos papéis vendidos, que representam uma média aproximada de $1.300 \mathrm{~kg}$ mensais.

Não foi feito trabalho intenso com a população da cidade porque não haveria capacidade operacional para atender a demanda, mas atividades de Educação Ambiental dentro da própria Faculdade são consideradas pelo coordenador como o ponto mais fraco do programa, que ainda precisa ser desenvolvido. Na verdade houve bastante resistência de professores e funcionários à coleta seletiva do papel, com o motivo aparente da possibilidade de divulgação indevida de documentos.

\subsubsection{As parcerias}

A UNESP buscou apoio do UNIBANCO Ecologia para compra de contêineres. A FAPESP financiou a bolsa de iniciação científica que deu suporte ao projeto. Outras empresas como Tetra Pak, Bruno Biagioni Papéis e Papelões, Padreca Aparas, Toro, Mercedes-Benz e outras têm sido parceiras no desenvolvimento de tecnologias.

A venda do material coletado nos PEVs era feita, até meados de 1999, pela Ação da Cidadania de Botucatu, $\mathrm{ONG}$ de prestígio na cidade, com atuação filantrópica intensa e que recebe inclusive financiamento internacional para ações em geração de renda. Pela dificuldade de ter pessoas que pudessem se dedicar a gerenciar os aspectos operacionais da venda do material, acompanhando as retiradas 
e fazendo controle do material, a Ação da Cidadania declinou da participação no projeto.

A UNESP tem conseguido, por meio deste programa, coletar plásticos necessários para suas pesquisas, ao mesmo tempo que dá o exemplo para a sociedade local e incentiva ações de coleta seletiva e reciclagem.

A Prefeitura Municipal de Botucatu não tem, historicamente, investido na coleta seletiva, tendo inclusive rejeitado um projeto apresentado por um professor da UNESP. Entretanto a gestão atual criou a Secretaria Municipal do Meio Ambiente, que tem planos de iniciar a atividade, e tem buscado o apoio técnico e didático da Universidade.

A bolsa de iniciação científica é uma parceria que proporciona à UNESP mão-de-obra para executar a coleta seletiva e, à FAPESP, atingir os seus objetivos na aplicação de recursos em pesquisa. 


\section{DISCUSSÃO}

Neste capítulo são discutidos os resultados nas suas várias dimensões. Para maior riqueza da discussão, alguns dos resultados obtidos nos estudos de caso serão comparados com dados correspondentes, obtidos na literatura ou calculados a partir delas. Para tal comparação serão especialmente úteis os programas dos Municípios de Belo Horizonte (MG) e Porto Alegre (RS), e os dados de alguns países.

\subsection{Dimensão operacional}

\subsubsection{Coleta Seletiva}

Em quase todos os programas coexistem diferentes formas de coleta. Isto resulta de características topográficas do município, das características dos resíduos a serem coletados, dos objetivos e propostas do programa e de recursos financeiros disponíveis.

$\mathrm{Na}$ Tabela 8.1 pode-se observar que diferentes modelos proporcionam também diferentes índices de eficiência de utilização dos recursos humanos e dos veículos. Foram utilizadas, como base de cálculo, as horas mensais correspondentes aos dias de trabalho conforme informado em cada caso - 22 ou 26 dias trabalhados por mês - e foi considerada a carga de 8 horas diárias de trabalho. Eventuais horas ociosas foram consideradas horas trabalhadas. Em Porto Alegre foi admitido o regime de 26 dias, predominante na maioria dos casos. 
Tabela 8.1. Eficiência de utilização de recursos humanos e veículos na coleta seletiva de resíduos sólidos domésticos em vários municípios.

\begin{tabular}{l|l|c|c}
\hline & \multicolumn{1}{|c|}{ Localidade } & $\begin{array}{c}\text { Resíduos } \\
\text { coletados } \\
\text { (kg / trabalhador. h) }\end{array}$ & $\begin{array}{c}\text { Resíduos } \\
\text { coletados } \\
\text { (kg / veículo. h) }\end{array}$ \\
\hline Estudos de caso & Embu & 34 & 136 \\
& Campinas & & \\
& $\quad$ Porta-a-porta & 24 & 133 \\
& PEV Comunidades org. & 75 & 151 \\
& Santos & 11 & 71 \\
& Goiânia & 39 & 200 \\
& Botucatu & 15 & 62 \\
\hline Referências & Porto Alegre (a) & ND & ND \\
bibliográficas & Belo Horizonte & ND & ND \\
\hline
\end{tabular}

(a) calculado com dados de PEREIRA e SANTOS (1998)

(b) calculado com dados de MOTTA (1998)

Nos municípios visitados, o melhor aproveitamento de mão-de-obra ocorre na modalidade entrega voluntária - PEV no município de Campinas. Trata-se de uma atividade mecanizada, sendo o contêiner vazio descarregado do caminhão e o contêiner cheio carregado por processos automatizados, de forma que apenas o motorista trabalha. O pior aproveitamento ocorre no mesmo município, na coleta em comunidades organizadas, provavelmente devido à distância entre os pontos de coleta e a usina do DLU. Os contêineres utilizados (tambores metálicos) exigem a presença de ajudantes, e as longas distâncias entre a central de triagem e os locais de coleta faz com que a mão-de-obra ficasse ociosa por um período importante de tempo. As recentes parcerias com unidades descentralizadas de triagem, como a instalada no presídio Ataliba Nogueira, podem reduzir este problema.

O melhor aproveitamento de veículo, entre os municípios visitados, ocorre em Santos, onde predomina a coleta porta-a-porta e é utilizado caminhão de carroceria aberta alterada. Ocorre que os caminhões são utilizados basicamente no período da manhã, ou seja, seria possível ampliar a coleta sem a necessidade de investimento em novos equipamentos. 
Nos três casos estudados de programas promovidos por prefeituras nota-se modelos distintos de coleta do ponto de vista de organização. Em Campinas, o órgão municipal fornece equipamentos e mão-de-obra para coleta; em Embu fornece equipamentos, sendo a mão-de-obra proveniente da cooperativa; em Santos a coleta é contratada junto a uma empresa privada. Em Embu problemas de segurança pública impedem o trabalho noturno, que poderia melhorar o aproveitamento dos caminhões, que seria especialmente importante após a recente a redução de um caminhão da frota.

Em nenhum dos casos estudados o rendimento de resíduos coletados por caminhão atingiu o rendimento obtido em Porto Alegre, apesar de que em Santos são utilizados veículos do mesmo tipo. A alta eficiência de coleta por veículo em Porto Alegre é atribuída por PEREIRA e SANTOS (1998) à otimização da frota e das rotas. Pode haver diferenças também devidas à densidade demográfica dos municípios, mas não foram obtidos dados sobre essa variável. Note-se que ambos os municípios obtêm melhor rendimento por veículo que Campinas, onde são utilizados caminhões compactadores.

São variadas as soluções operacionais adotadas nos programas. Cada programa utiliza um modelo diferente de caminhão. A realização conjunta da coleta regular e de recicláveis seria desejável para as prefeituras, porém a dificuldade de encontrar um modelo ideal de caminhão ainda persiste. Há uma coincidência interessante que é o fato de as melhores eficiências na utilização de veículos serem constatadas nos programas que utilizam caminhões de carroceria alterada (mais alta).

Segundo ALBOREDA (1997) os PEVs estão sendo cada vez menos utilizados nos programas de coleta seletiva no Brasil, sendo o de Belo Horizonte o único que investe intensamente neste sistema. Entretanto, o bom aproveitamento de mão-de-obra desta modalidade de coleta em Campinas mostra que o sistema tem vantagens que podem ser aproveitadas, sempre que houver a possibilidade de uso de 
equipamentos mais mecanizados. Este parece ser também um sistema adequado para utilização em condomínios residenciais.

A manutenção dos veículos tem extrema importância na atividade de coleta. Nos programas visitados predominam veículos relativamente antigos, com idade acima da recomendada por diversos profissionais da área (5 anos). A necessidade de constantes trabalhos de manutenção pode provocar falhas na programação da coleta. Tais falhas podem gerar descontentamento e descrédito na população atendida, reduzindo a adesão da população, como constatado em Embu. Este problema tem se agravado com as recentes restrições orçamentárias a que estão sujeitas as prefeituras municipais. Em Campinas o problema é parcialmente resolvido com disponibilidade de vários caminhões reserva. Os caminhões compactadores têm quase nove anos, e de uma frota de nove veículos são utilizados normalmente apenas cinco. Em Santos e Goiânia, onde a operação e manutenção dos veículos está sob responsabilidade privada, o problema fica atenuado, de forma que parcerias neste sentido podem ser úteis para solucionar o problema.

Em Embu a retirada de um dos caminhões do serviço por contenção de despesas trouxe complicações à operação. Uma solução possível seria a operação noturna de um dos outros veículos, com deslocamento dos cooperados para trabalhar neste horário. Essa solução foi descartada por medo da deficiente segurança pública no município.

\subsubsection{Triagem dos resíduos}

A triagem é realizada em manualmente em todos os casos estudados. Apenas um separador magnético para sucatas metálicas foi localizado, e ainda assim sua eficiência na prática é relativamente baixa.

Nos cálculos efetuados, foram consideradas atividades de triagem não apenas a catação em esteira ou mesa, mas também a organização dos estoques, transporte interno e operação de prensas. O uso da esteira mecânica está associado na verdade à 
maior quantidade de resíduos. Nesses dois casos ocorre o aproveitamento de mão-deobra não especializado, o que pode efetivamente ter concorrido para haver a menor eficiência neste aproveitamento.

Tabela 8.2. Eficiência da mão-de-obra de triagem em programas de coleta seletiva em diversos municípios brasileiros

\begin{tabular}{l|l|c}
\hline & \multicolumn{1}{|c}{ Localidade } & $\begin{array}{c}\text { Eficiência de } \\
\text { Mão-de-obra } \\
\text { (kg / trabalhador. } \\
\text { h) }\end{array}$ \\
\hline Estudos de caso & Embu & 36 \\
& Campinas & 24 \\
& Goiânia & 10 \\
& Santos & 19 \\
\hline Referências & Porto Alegre $\left(^{*}\right)$ & 25 \\
bibliográficas & & \\
\hline
\end{tabular}

(*) Fonte: PEREIRA e SANTOS (1998)

$\mathrm{O}$ alto rendimento da mão-de-obra de triagem em Embu deve-se, em parte, à presença predominante de sucata ferrosa, mais densa, e adicionalmente pelo lay-out da triagem, mais compacto, apesar de não ser utilizada esteira motorizada. Por outro lado, em Goiânia pode-se atribuir a eficiência relativamente baixa ao fato de o programa estar em fase inicial, havendo ainda etapas do projeto a serem implantadas, inclusive reformas na área de triagem para correção de defeitos do projeto original da moega e mesa catação, e também ao fato de que a triagem é bastante refinada pelo fato de serem processados o papel e papelão e parte dos plásticos na própria usina.

Segundo ALBOREDA (1997), o armazenamento médio dos materiais em unidades de triagem é de 15 dias. Nos programas ora estudados este tempo varia muito de material para material, sendo que geralmente plásticos são armazenados por mais tempo porque estão presentes em porcentagens menores que papéis e metais ferrosos, os quais atingem mais rapidamente quantidades mínimas exigidas pelos compradores.

Uma questão operacional interessante que surge é a descentralização das usinas de triagem. Em função do custo do transporte, pode ser preferível ter unidades próximas aos locais de geração onde os resíduos possam ser triados, de modo a 
viabilizar o transporte dos materiais recicláveis para unidades centrais de distribuição ou diretamente para as fábricas, dependendo da quantidade coletada. Não foram coletados dados que permitissem a comparação da eficiência em termos das distâncias percorridas pelos veículos, o que poderia demonstrar este aspecto, mas as experiências de Porto Alegre, onde funcionam 8 unidades, e de Campinas, que caminha neste sentido, mostram que em especial para cidades de maior porte isso pode facilitar a viabilização dos programas. Além disso, a existência de unidades descentralizadas pode favorecer a entrega voluntária e um contato mais próximo entre os coletores e os moradores, melhorando a adesão da população. Entretanto, a descentralização extrema pode levar à falta de economia de escala, por isso deve ser feita com cautela.

A Tabela 8.3 mostra o índice de rejeitos estimado para cada município. O caso de Campinas é atípico. Em 1998 houve problemas operacionais que impediram a triagem dos resíduos durante boa parte do ano e havia pouco mercado para resíduos não triados. Por este motivo a maior parte dos resíduos coletados não pode ser comercializada. Com as novas parcerias, o resíduo sem triar já está sendo escoado, estando previsto um nível de rejeitos da ordem de 25\%. Em Botucatu não há controle sobre a quantidade de rejeitos. Em Belo Horizonte não foram localizados dados bibliográficos a respeito.

\begin{tabular}{|c|c|c|}
\hline & Município & $\begin{array}{l}\text { Quantidade estimada de } \\
\text { rejeito (\% da coleta) }\end{array}$ \\
\hline Estudos de caso & $\begin{array}{l}\text { Embu } \\
\text { Santos } \\
\text { Campinas } \\
\text { Goiânia }\end{array}$ & $\begin{array}{r}19,4 \\
8,0 \\
64,0 \\
16,7\end{array}$ \\
\hline $\begin{array}{l}\text { Referências } \\
\text { bibliográficas }\end{array}$ & Porto Alegre (a) & 20,0 \\
\hline
\end{tabular}

(a) Fonte: PEREIRA e SANTOS (1998)

\subsubsection{Processamento industrial}

Somente os programas de Goiânia e Botucatu instalaram novos equipamentos para processamento industrial dos materiais coletados. Os demais se limitaram a 
montar estruturas de coleta e triagem, aproveitando a existência de indústrias recicladoras existentes nos mercados locais. Tais mercados locais apresentaram limitações importantes. Na região de Goiânia, por exemplo, foram fechadas recentemente, por motivos econômicos, pequenas fundições de alumínio que facilitavam o escoamento de boa parte do material. Na região de Embu já há dificuldades para escoar o PET por saturação do mercado, prova de que para aumentar a quantidade reciclada deste material, serão necessários investimentos industriais.

Foram registradas manifestações de interesse de alguns entrevistados, que atualmente apenas coletam e triam, ou então que apenas comercializam materiais, em realizar mais etapas do processamento, como lavar e moer, em especial no caso dos plásticos. Este interesse poderia ser incentivado, e parcerias e políticas públicas de transferência de tecnologia poderiam viabilizar as ações.

É importante notar que não há necessidade de que as novas unidades realizem o processo completo de reciclagem dos materiais. No caso dos plásticos, por exemplo, é possível que sejam instaladas unidades de moagem e lavagem, que são etapas preparatórias para o coração do processo de reciclagem dos plásticos, que é a granulação. É importante que ao se implantar unidades deste tipo tome-se bastante cuidado com a qualidade do material intermediário produzido. Essa qualidade pode garantir o interesse das indústrias que produzem produtos reciclados (AGUIAR e PHILIPPI 1998).

Devido ao fato de que a tecnologia de reciclagem das embalagens multicamada tipo longa vida da Tetra Pak ainda não estar muito difundida, apenas em Campinas ela é separada para reciclagem, e ainda assim tem havido dificuldades para vender o material. Pode-se prever que no longo prazo as embalagens longa vida devem passar a ser progressivamente reconhecidas como recicláveis, à medida que essa tecnologia seja divulgada e ganhe economia de escala. 
Estes fatos demonstram que o desenvolvimento de indústrias de ação local contribuiria decisivamente para que maior quantidade de resíduos pudesse ser reciclada. Pode-se concluir, por fim, que é importante desenvolver negócios locais de reciclagem, localizados a distâncias aceitáveis dos centros geradores, para consumir os materiais coletados nos programas. É preciso, portanto, que se alie as políticas industrial, de ciência e tecnologia e de resíduos sólidos, em nível municipal e regional, para viabilizar o escoamento dos materiais recicláveis. Seria extremamente proveitoso se mais atividades como as de pesquisa da UNESP fossem aliadas a programas amplos de coleta seletiva.

\subsubsection{Outros aspectos}

As parcerias tipo cessão de equipamentos em comodato são uma forma especialmente interessante de viabilizar operacionalmente a coleta seletiva, a triagem e a reciclagem. Em Goiânia esta é a modalidade de contrato entre a Sociedade Goiana de Cultura e a COOPREC. Em Campinas o DLU tem uma prensa oferecida por um dos sucateiros. Em Santos os mesmos caminhões antigamente utilizados pela PRODESAN na coleta seletiva passaram a ser usados pela TERRACOM quando da privatização da coleta.

Outro aspecto que chama a atenção é a falta de apoio de técnicos e engenheiros que acompanhem constantemente os trabalhos nas centrais de triagem e usinas de reciclagem. As consequências observadas são o uso inadequado, ou pelo menos não otimizado de equipamentos em algumas das usinas, inclusive com riscos para os operadores. Em pelo menos um programa foi identificada a aquisição de equipamentos deficientes, por falta de fiscalização dos fornecedores e de exigência de condições contratuais. A abertura de espaço para estagiários de escolas técnicas, que contribuiriam nas atividades de manutenção de equipamentos, é uma das propostas em estudo em Goiânia. Essa idéia poderia ser aplicada também em outros programas, e estendidas ao apoio no planejamento de métodos e processos de trabalho. 


\subsection{Dimensão econômica}

A apuração de custos dos programas de coleta seletiva não é tarefa das mais simples, pois os dados dificilmente são registrados com exatidão e disponibilizados. Mesmo nas publicações que divulgam custos, como JARDIM (1995), EIGENHEER (1998) e CEMPRE (1999), não há uma uniformidade no estabelecimento de critérios para contabilização dos custos. Em geral aborda-se somente os custos da administração municipal, o que pode levar a comparar custos de modelos diversos, mascarando uma série de características dos programas. Por isso as parcelas dos custos foram re-organizadas conforme definido no Capítulo 5, de modo a permitir uma melhor comparação entre os casos estudados. Tal procedimento causou diferenças entre os valores calculados neste trabalho e aqueles divulgados pelas instituições promotoras dos programas, o que não invalida os resultados anteriores, mas aponta para a necessidade de padronização do procedimento a fim de facilitar futuros estudos e o próprio monitoramento dos programas.

Em alguns casos houve ainda dificuldades especiais. No município de Santos a coleta é feita atualmente pela empresa TERRACOM, que não forneceu dados de composição de custos. Por isso o custo ora analisado é aquele que ocorria alguns meses antes, quando a coleta era realizada pela própria PRODESAN, o que por outro lado permitirá comparar o modelo atual de gestão e o anterior, oferecendo argumentos bastante ricos. Em Botucatu os custos são especialmente difíceis de apurar, pois há poucos registros e todos os profissionais envolvidos participam em tempo parcial nas atividades de coleta, triagem, processamento e administração, em particular no caso dos plásticos. Neste trabalho é considerada apenas a coleta de papel e papelão nos dois campi, para efeito de avaliação dos custos, e foram feitas estimativas da dedicação do pessoal operacional. 


\subsubsection{Custos de coleta e transporte}

Historicamente, como a coleta de resíduos foi predominantemente executada pela prefeitura ou por empresas contratadas por ela, o município era o único agente econômico que pagava os custos. Com a inclusão de outros níveis de governo, empresas, cooperativas e outras ONGs nas ações, os custos podem se diluir entre os agentes econômicos, sendo necessário portanto perceber outros pontos de vista.

\section{a) Custos unitários}

Os custos unitários de Coleta e Transporte variaram aproximadamente entre US\$ 50 e US\$ 260 por tonelada coletada (Figura 8.1). O custo mais baixo foi o de Botucatu, onde a coleta é feita em parte por entrega voluntária, em parte nos locais de trabalho da Universidade pelo pessoal da limpeza, estando envolvida mão-de-obra de funcionários, e onde o transporte é feito pelo comprador ou por contratado. $\mathrm{O}$ custo mais elevado ocorre em Santos - custo referente à coleta quando realizada pela

Figura 8.1. Custos de coleta e transporte por tonelada coletada de material em diversos municípios brasileiros

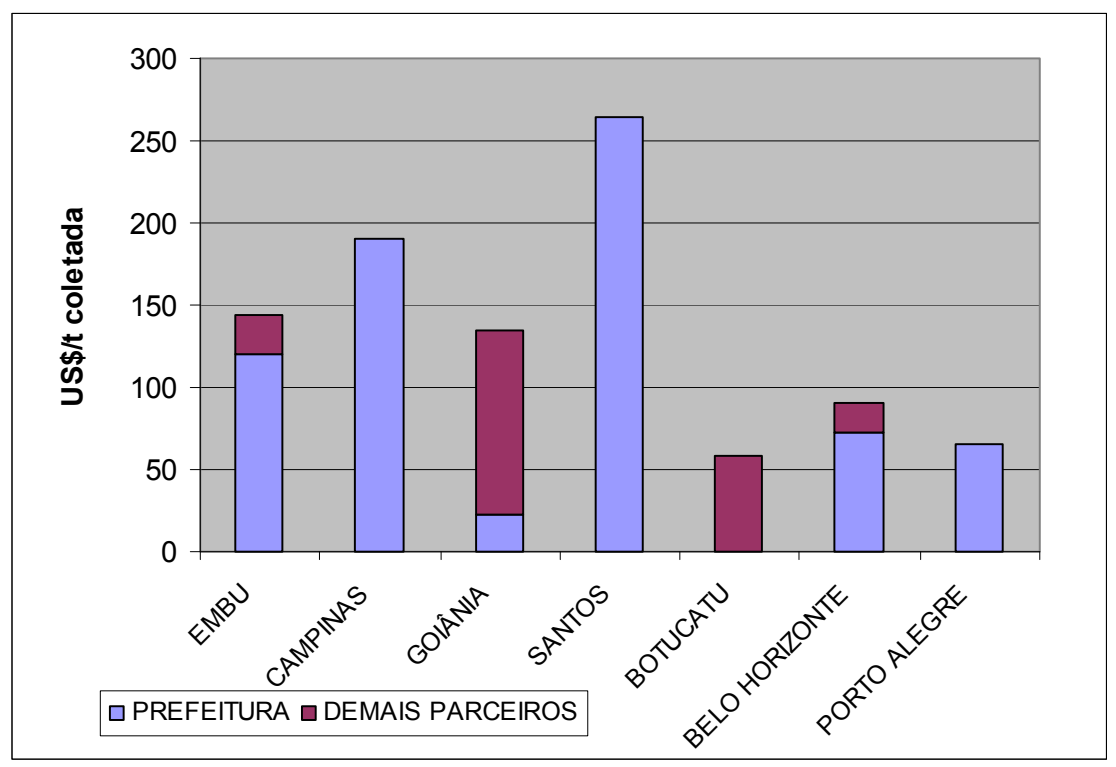


PRODESAN. Se fosse incluída ainda a parcela dos custos administrativos atribuídos à coleta, o valor subiria para US\$ 319/t coletada. Comparando tais custos com o indicado em bibliografia, os custos de Porto Alegre ainda são mais baixos que os de todos os casos estudados.

Pode-se observar que em todos os programas promovidos pelos órgãos municipais - Embu, Campinas, Porto Alegre e Belo Horizonte - as despesas de coleta e transporte referentes à coleta seletiva são pagas pelo poder público. Apenas nos casos de Embu e de Belo Horizonte uma parte do custo de coleta é de responsabilidade de um parceiro, respectivamente a COOPERMAPE e a ASMARE, que são organizações de catadores. Em Botucatu e em Goiânia a coleta seletiva é de iniciativa independente, por isso os custos para a prefeitura são muito mais baixos, sendo virtualmente zero no caso de Botucatu. Isto reforça a importância das iniciativas independentes.

Considerou-se, para efeito de comparação dos custos para as prefeituras, que a COMURG de Goiânia faça o pagamento à COOPREC pelo serviço de coleta de resíduos sólidos pelo preço ajustado.

\section{b) Composição dos custos}

Os custos de mão-de-obra representam a parte mais significativa, variando de 35 a 80\% (Figura 8.2). Em segundo lugar, aparece o custo de depreciação/aluguel do veículo que representa de 18 a $61 \%$, e que é bastante influenciado pela idade dos equipamentos em uso.

Para que os custos de manutenção fossem plenamente comparáveis, dever-se-ia observar também níveis equivalentes de falha nos equipamentos. Um baixo custo atual de manutenção pode significar que o equipamento não tem tido manutenção adequada, o que pode causar um número excessivo de paradas para pequenos consertos, e consequentemente falhas na programação de coleta. Este controle não é 
feito em nenhum dos programas estudados, portanto os resultados têm que ser analisados levando em conta tal limitação.

Figura 8.2. Distribuição percentual dos custos de coleta e transporte seletivos de resíduos sólidos domésticos nos em alguns municípios brasileiros (estudos de caso)

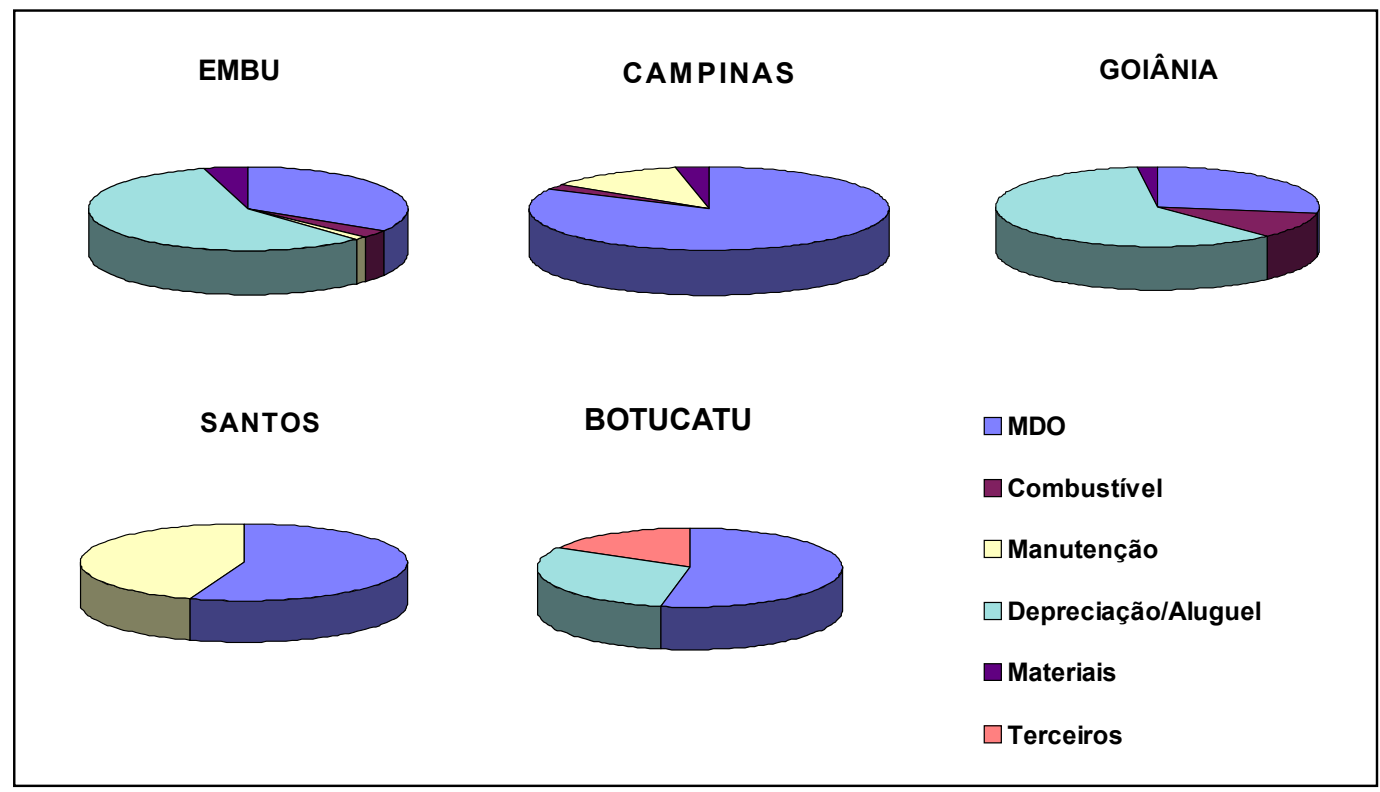

Os custos de depreciação em Campinas, Santos e Embu foram considerados nulos porque todos os equipamentos foram considerados já depreciados. Em Botucatu o transporte é feito por terceiros, não tendo havido investimentos específicos.

Observa-se que há consistência entre as proporções obtidas em Embu e em Goiânia, onde a coleta utiliza mão-de-obra de cooperados; neste caso predominam os custos de equipamentos. Há consistência também entre os resultados de Santos e Campinas, onde predomina a coleta porta-a-porta, e neste caso o custo da mão-deobra é o mais importante.

Nota-se que em Belo Horizonte, onde o sistema de PEVs é bastante utilizado, a mão-de-obra tem uma participação menor nos custos. O resultado de Porto Alegre, 
com predominância dos custos de mão-de-obra, é consistente com os resultados de Campinas e Santos.

A redução dos custos de mão-de-obra de coleta deve ser buscada por meio de parcerias com os sistemas informais já existentes (catadores e sucateiros). Outra forma seria a proposta por CALDERONI (1998), de que a empreiteira receba por tonelada coletada seletivamente exatamente o mesmo que recebe pela coleta regular, ficando com a propriedade do material. Essa modalidade pode criar conflitos em

Figura 8.3. Distribuição percentual dos custos de coleta e transporte seletivos de resíduos sólidos domésticos nos em alguns municípios brasileiros (referências bibliográficas)

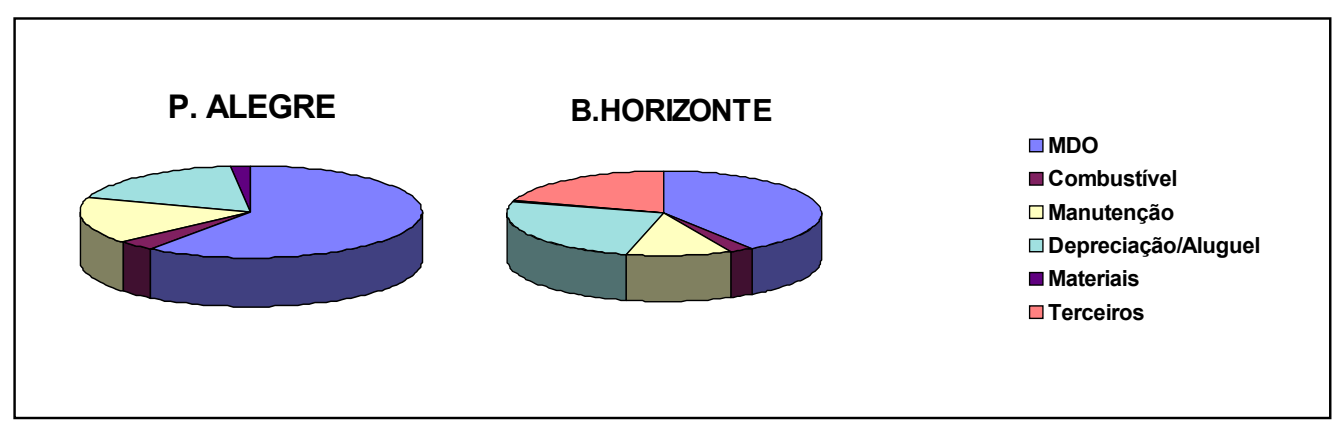

áreas com intensa atuação de catadores. Uma solução alternativa poderia ser a contratação dos catadores como funcionários da empresa, mas a experiência verificada nos casos mostra que seria necessária a adaptação dos catadores ao sistema de pagamento de salários, e não de rendimentos diários, como funciona no mercado informal de sucatas.

A modalidade de contratação de empreiteira com pagamento por serviço prestado, nos moldes do programa de Santos, demonstrou trazer uma redução modesta dos custos em relação ao serviço prestado pela estrutura municipal. A diferença dos custos operacionais é de apenas $13 \%$ a favor da operação terceirizada. Teria havido alguma falha na tomada de preços? Mesmo em Campinas, onde o modelo tem semelhanças pois a prefeitura arca diretamente com os custos tanto da coleta como da triagem, os valores são mais baixos. 
Esta opção de contratação poderia trazer vantagem no caso de ser necessário investimento em equipamento e de o poder público não poder ou não desejar se endividar para aquisição do equipamento, o que não parece ter sido o caso, porque não houve ampliação do serviço. No entanto, não traz, necessariamente, redução de custos se for feita com mão-de-obra assalariada.

Conclui-se portanto que, no caso de Santos, uma nova mudança no modelo de gestão poderia trazer uma queda mais acentuada dos custos de coleta, como demonstram os resultados nas outras cidades.

\subsubsection{Custos de triagem}

Uma limitação importante ao utilizar o custo da triagem de resíduos como variável de análise é que o número não explicita o estado final de seleção e preparação dos resíduos (grau de classificação e limpeza dos materiais, enfardamento, etc.). Neste caso seria importante que o número fosse acompanhado de tais especificações. Grosso modo, no presente estudo admite-se condições aproximadamente equivalentes dos materiais vendidos em cada programa, principalmente quanto à quantidade de impurezas presentes. Em Embu e em Botucatu não é efetuada prensagem dos materiais, o que introduz alguma distorção, pois resíduos enfardados encerram maior valor de mão-de-obra e são mais facilmente comercializados.

\section{a) Custos unitários}

Os custos de triagem variam aproximadamente entre 25 e 120 US\$/t (Figura 8.4). Em Botucatu a triagem dos plásticos é feita na própria Universidade por contratados temporários, mas não foram apresentados dados que permitissem a estimativa. A triagem do papel/papelão é feita pelo sucateiro, e também não foram coletados os dados correspondentes. 
Figura 8.4. Custo da triagem de resíduos de coleta seletiva em vários municípios brasileiros

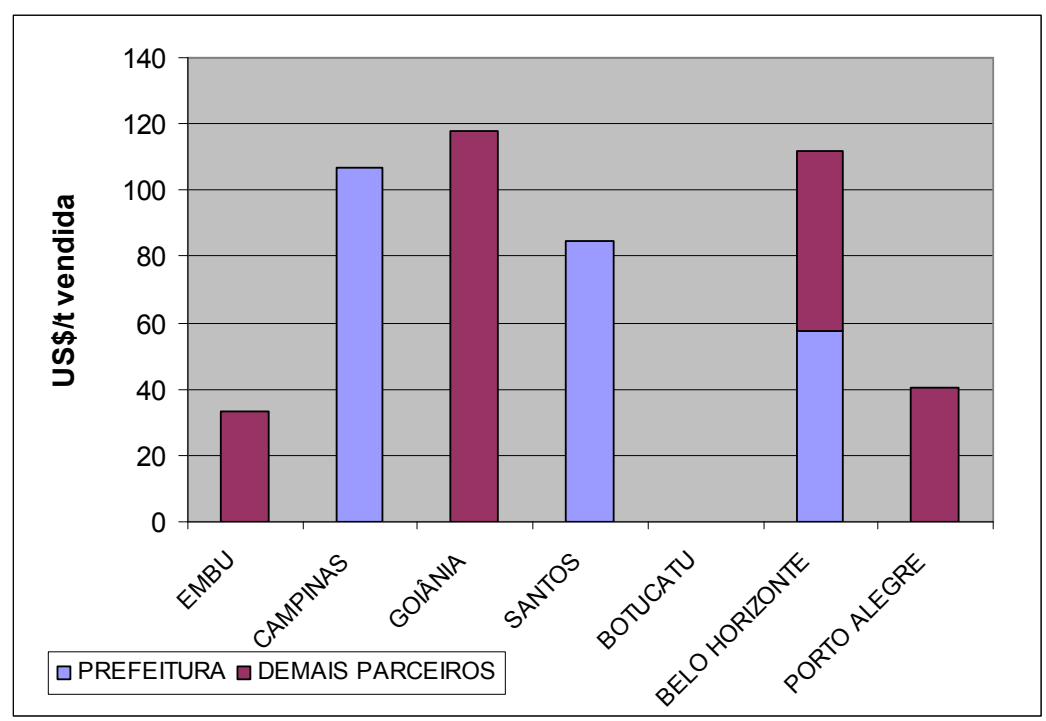

Nos programas em que há envolvimento de cooperativas e associações de catadores - Embu, Goiânia, Belo Horizonte e Porto Alegre - os custos de triagem, do ponto de vista da administração municipal são muito baixos ou nulos porque a triagem é executada pelas cooperativas. Este fato mostra, por um lado, que esta vantagem das parcerias já foi incorporada por diversos programas; por outro mostra que pode ser uma diretriz para aqueles programas que ainda não adotaram esta idéia.

No outro extremo, há o programa de Campinas, onde o custo apurado foi alto, mas a tendência é de que a triagem seja descentralizada para parceiros e assim seja bastante reduzido; em Santos estes custos decorrem da utilização da mão-de-obra dos ex-internos do serviço de saúde mental, que recebem pelo serviço. Como os processos utilizados para triagem são bem pouco automatizados, decorre que há poucos equipamentos para receber cuidados de manutenção, o que resulta é claro em custos mais baixos neste item. 


\section{b) Composição de custos}

A mão-de-obra representa de 70 a $100 \%$ do total dos custos de triagem (Figura 8.5). É evidente que, nos casos em que representa 100\%, certamente há ainda custos ocultos a contabilizar, principalmente com terrenos e edifícios.

Custos de terrenos e edifícios não aparecem porque a maioria dos terrenos são de propriedade de um dos parceiros, não havendo pagamento de aluguel. Neste ponto é preciso considerar dois pontos de vista. Primeiro, como custo de capital imobilizado, o valor do terreno precisaria ser considerado pela instituição promotora do programa. O segundo ponto é que para comparação dos programas, não é adequado incluir este custo, pois o valor dos terrenos varia muito de cidade para cidade, podendo mascarar vantagens e deficiências nas demais parcelas.

Figura 8.5. Composição percentual dos custos de triagem de resíduos sólidos domésticos em alguns municípios brasileiros

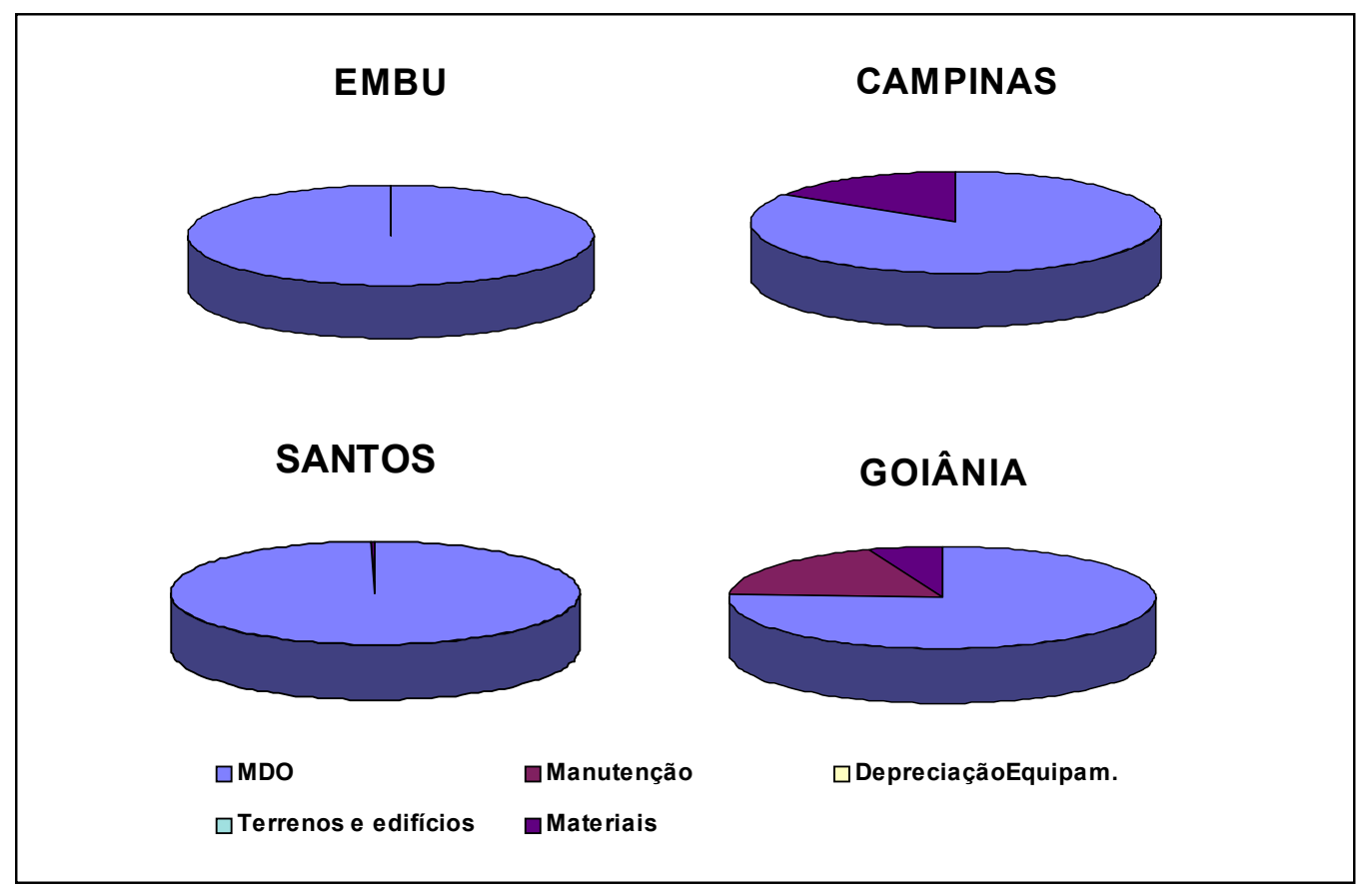


Cabe ressaltar que na maioria das usinas de triagem, mesmo quando cedidas a cooperativas, o investimento para construção de edifícios e aquisição de equipamentos é realizado com recursos públicos, como em Embu, Belo Horizonte e Porto Alegre. No caso de Campinas, em que foi firmado recentemente convênio com empresa privada, e no caso de Goiânia, em que a Sociedade Goiana de Cultura deu recursos em contrapartida no Projeto Meia Ponte, vê-se exemplos da possibilidade de participação da iniciativa privada neste aspecto.

Há outros custos existentes que não puderam ser quantificados, como materiais são obtidos por doação tais como sacos de estopa tipo big-bag reutilizados em Embu. Essa doação representa um custo compartilhado, reduzindo a carga para quem opera a triagem, viabilizando a atividade. Porém, se não houvesse a doação, este custo teria que ser assumido pela cooperativa ou prefeitura. Tais custos não estão incluídos no presente estudo, permanecendo ainda mascarados.

Figura 8.6. Composição percentual dos custos de triagem de resíduos sólidos domésticos em municípios brasileiros (referências bibliográficas)

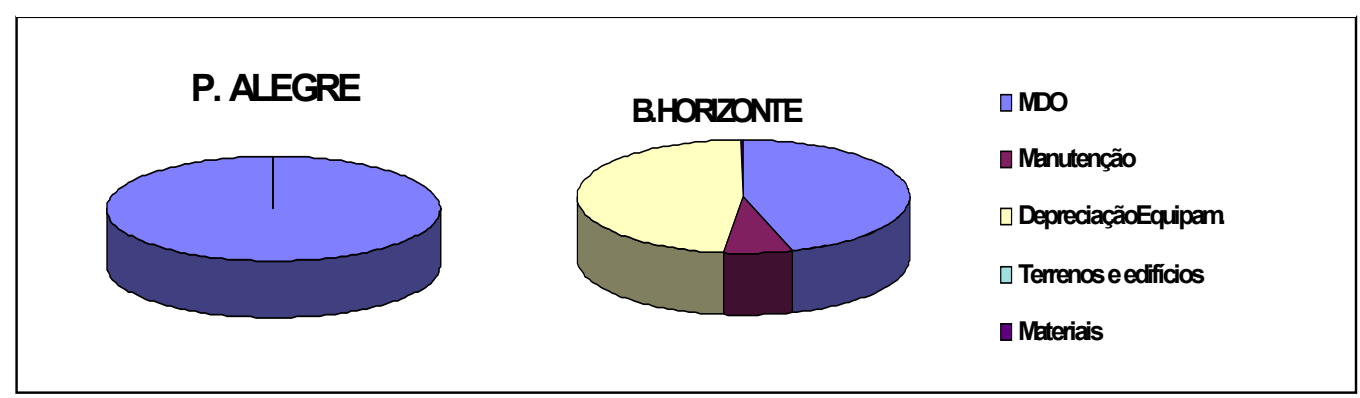

\subsubsection{Industrialização dos materiais}

Nos programas de Goiânia e Botucatu estão integradas unidades de processamento de materiais: plásticos, em Botucatu, e plásticos, papel e papelão e matéria orgânica em Goiânia. Analisar os custos unitários destes processos, em detalhe, fugiria aos objetivos deste trabalho devido às diferenças tecnológicas e devido à insuficiência de precisão dos dados para cada operação unitária do processo. No entanto, pode-se destacar que no Campus Lageado da UNESP, onde é processado 
o plástico, os custos incluindo coleta, triagem e processamento situam-se na ordem de US\$ 220/t, e que em Goiânia os custos estão na ordem de US\$ 400/t, consequência do fato de a usina ainda não ter atingido a produtividade programada no projeto.

\subsubsection{Custos Unitários Totais}

Os custos unitários totais foram calculados por tonelada de resíduo vendida, ou seja, pelo material que volta efetivamente à cadeia produtiva Em Belo Horizonte e Botucatu, onde não há como calcular o índice de rejeitos, foi utilizada a tonelada bruta vendida, sem levar em conta rejeitos eventualmente presentes.

O programa com custo unitário mais alto por tonelada reciclada foi o de Campinas, devido ao problema já relatado de escoamento do material (Figura 8.7). Consideradas as novas condições de trabalho, com novas parcerias, pode-se prever um custo da ordem de $\mathrm{R} \$ 250 / \mathrm{t}$, o que já se aproxima dos valores dos outros programas , apesar de ainda estar na faixa superior dos custos. Os custos de Goiânia

Figura 8.7. Custo total dos programas de coleta seletiva em vários municípios brasileiros

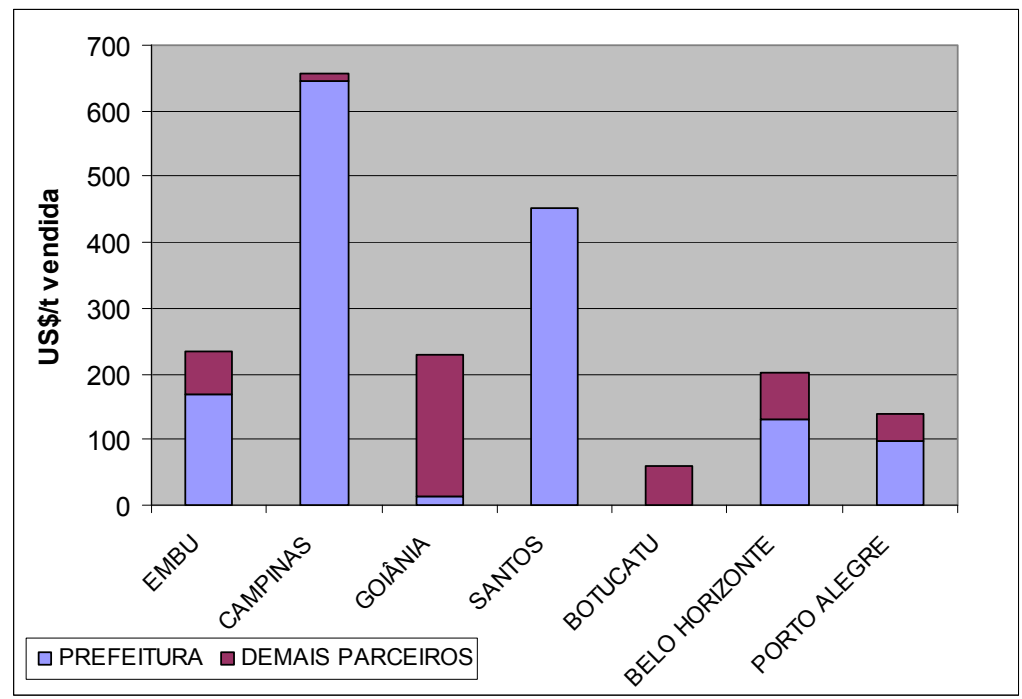


podem ser considerados altos e isto ocorre, e conforme já ressaltado anteriormente, porque nem todos os seus componentes estavam em pleno funcionamento no período a que se referem os dados, por ser um sistema em implantação. Os custos unitários deverão cair quando a unidade estiver operando com toda sua capacidade. No caso de Santos, o contrato com a TERRACOM para coleta é o principal responsável pelos custos altos. Se houvesse apoio municipal aos catadores, estes custos seriam sensivelmente mais baixos.

Verifica-se que em relação aos custos totais da coleta seletiva as prefeituras contribuem ainda com partes significativas do total, porque a coleta, que é a atividade mais cara, ainda é paga pelo Município (Figura 8.8). Nota-se, entretanto, que os programas que já fizeram parcerias com cooperativas têm os custos significativamente mais baixos. Em Campinas as novas parcerias com unidades descentralizadas de triagem devem fazer baixar significativamente os custos. O mesmo já não se pode esperar de Santos, pois com a privatização o preço contratado para a coleta seletiva é US\$281/t coletada, 13\% abaixo dos R \$ 315 que custava para a PRODESAN executar (inclusive custos administrativos). No caso do programa do Bairro do Macuco, extinto pela administração municipal atual, cada trabalhador ecológico recebia uma ajuda de custo de R\$ 180 (US\$ 172) para realizar a coleta, que por não haver dados oficiais podemos estimar em aproximadamente $2 \mathrm{t} / \mathrm{mês}$, o que resulta num custo de US\$ 86/t. Em Porto Alegre, onde é utilizada um modelo operacional tradicional com caminhões, cada tonelada custa para a prefeitura aproximadamente US\$ 70. O valor é muito mais baixo que o pago em Santos e muito próximo ao custo dos trabalhadores ecológicos. Claro está que o carrinheiro que não recebe nenhuma ajuda pode também, eventualmente, realizar o mesmo trabalho sem custo aparente, e que talvez o funcionário da PRODESAN ou da TERRACOM tenha benefícios a mais. Portanto a busca de parcerias com os carrinheiros no modelo dos trabalhadores ecológicos faz sentido do ponto de vista econômico. 
Figura 8.8. Distribuição percentual dos custos dos programas de coleta seletiva e reciclagem de resíduos sólidos domésticos nos em alguns municípios brasileiros

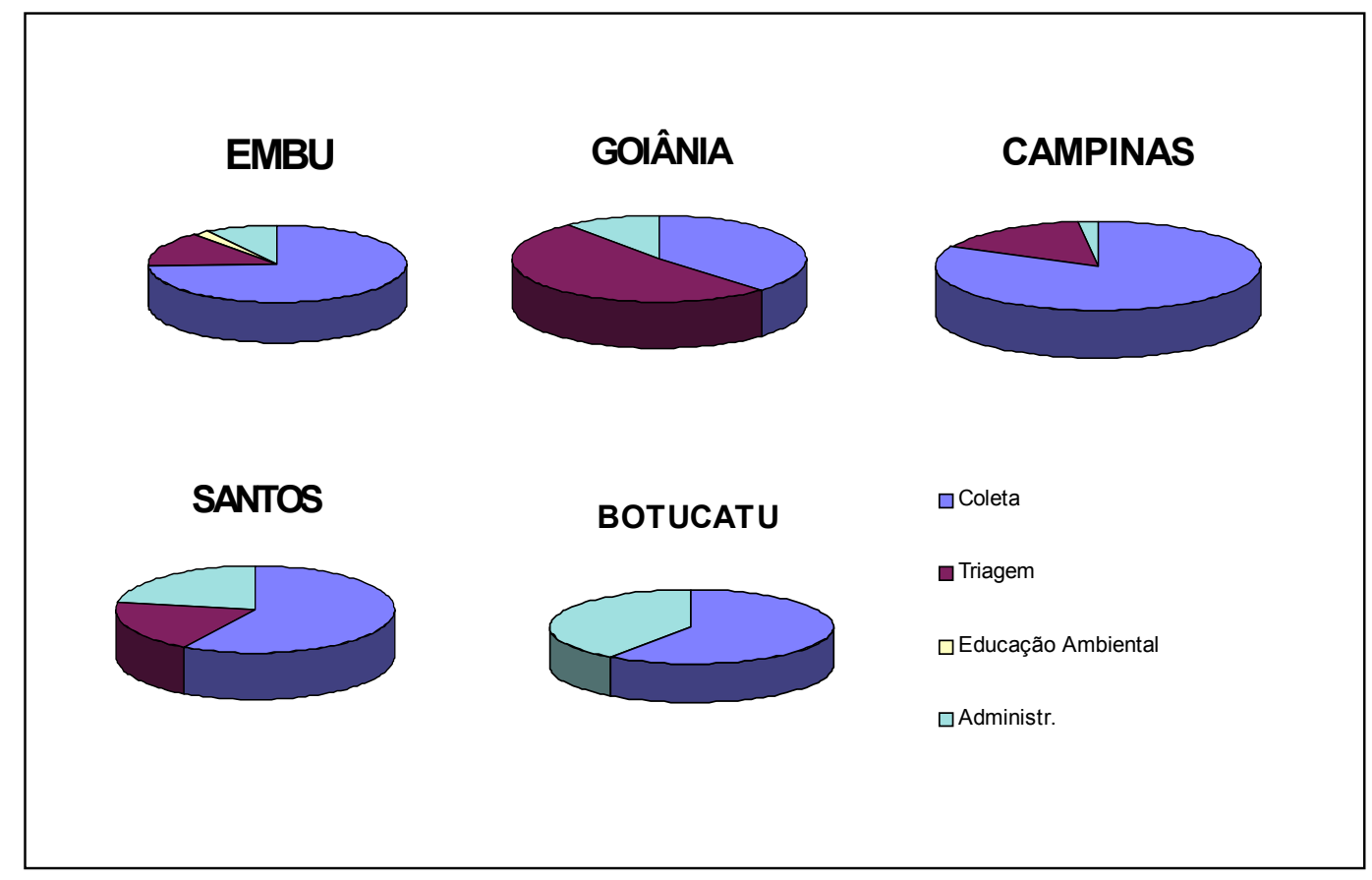

$\mathrm{O}$ alto custo de Campinas se deve em parte às dificuldades operacionais encontradas em 1998, devido às paradas de manutenção e reforma dos equipamentos da triagem, mas as perspectivas são claras no sentido de fazer cair os custos em função do melhor aproveitamento dos materiais na venda, com as novas parcerias.

Ao analisar a composição dos custos, oberva-se que o item Coleta e Transporte representa, em três dos casos, o maior componente. Nota-se que, do ponto de vista das prefeituras, essa ainda é uma oportunidade pouco explorada de parcerias.

No caso da triagem, que é o segundo item em importância, várias prefeituras estão entregando a operação a empresas ou cooperativas, o que já contribui para que nos programas estudados este componente tenha um peso mais baixo. Este passo é importante por representar a compreensão de que a triagem é uma atividade de produção, e como tal não cabe aos órgãos públicos executar. Em Goiânia o custo da 
triagem é mais alto porque exige-se uma triagem mais apurada para processamento dos materiais.

O fato de poucas vezes serem citados os custos com Educação Ambiental nos relatórios e nas entrevistas mostra que pode estar havendo pouca ação continuada em Educação Ambiental e motivação da população, ao mesmo tempo com certeza há um controle precário desses custos. O resultado típico é a queda da quantidade de resíduos coletada seletivamente (BARCIOTTE 1993). Outro dado é a queda de coleta por habitante servido após etapas de ampliação da área atendida.

Até o ponto em que foi possível apurar, os custos com Educação Ambiental variaram entre 2 e 5\%. Acontece que, também no caso da Educação Ambiental, há apoios aos programas como cessão de material gráfico que não aparecem nos demonstrativos financeiros, e portanto ficam mascarados. Apesar teoricamente possível, a estimativa deste valor iria além dos objetivos da presente pesquisa.

Foram incluídos no item Administração custos com mão-de-obra indireta e de coordenação do programa, principalmente. Variaram entre 2 e $12 \%$, sendo o caso de Botucatu (80\%) uma clara exceção devido aos inúmeros custos diluídos e mascarados presentes. As despesas com Administração também são um dado relativamente impreciso, e para o qual também não há critérios uniformes na divulgação dos programas, por isso foi preciso reordenar os dados segundo os critérios do presente trabalho.

Os resultados de Porto Alegre e de Belo Horizonte (Figura 8.9) são consistentes com os correspondentes estudos de caso, sendo que em Porto Alegre a coleta representa uma fatia maior dos custos, dado que é mais utilizada a coleta porta-a-porta. 
Figura 8.9. Distribuição percentual dos custos dos programas de coleta seletiva e reciclagem de resíduos sólidos domésticos nos em alguns municípios brasileiros (referências bibliográficas)

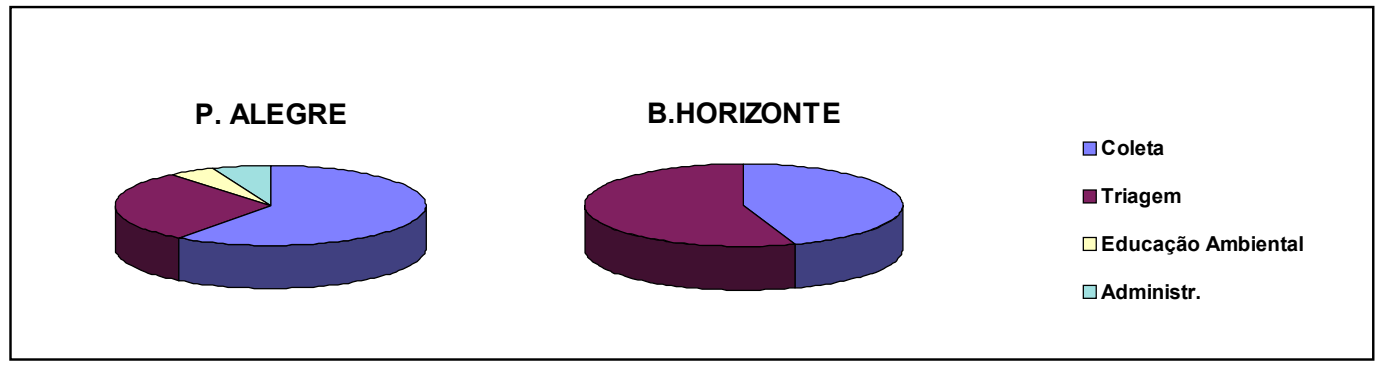

\subsubsection{O mercado de recicláveis}

Há alguns materiais que representam a maior parte do faturamento obtido (Figura 8.10), o que confirma a afirmação de WELLS e col. (1995). Tais materiais são aqueles materiais mais disponíveis ou de maior valor. Este fato tem um lado positivo, porque com o faturamento obtido destes materiais principais, é possível manter as atividades que envolvem materiais menos rentáveis, enquanto se buscam novos parceiros que proporcionem melhor rendimento para os materiais menos rentáveis.

Do ponto de vista da comercialização dos materiais, é importante o papel dos resíduos de origem comercial, principalmente papel/papelão e plásticos filme, na

Figura 8.10. Porcentagem do faturamento devida a diferentes materiais recicláveis nos programas de coleta seletiva em diversos municípios brasileiros.

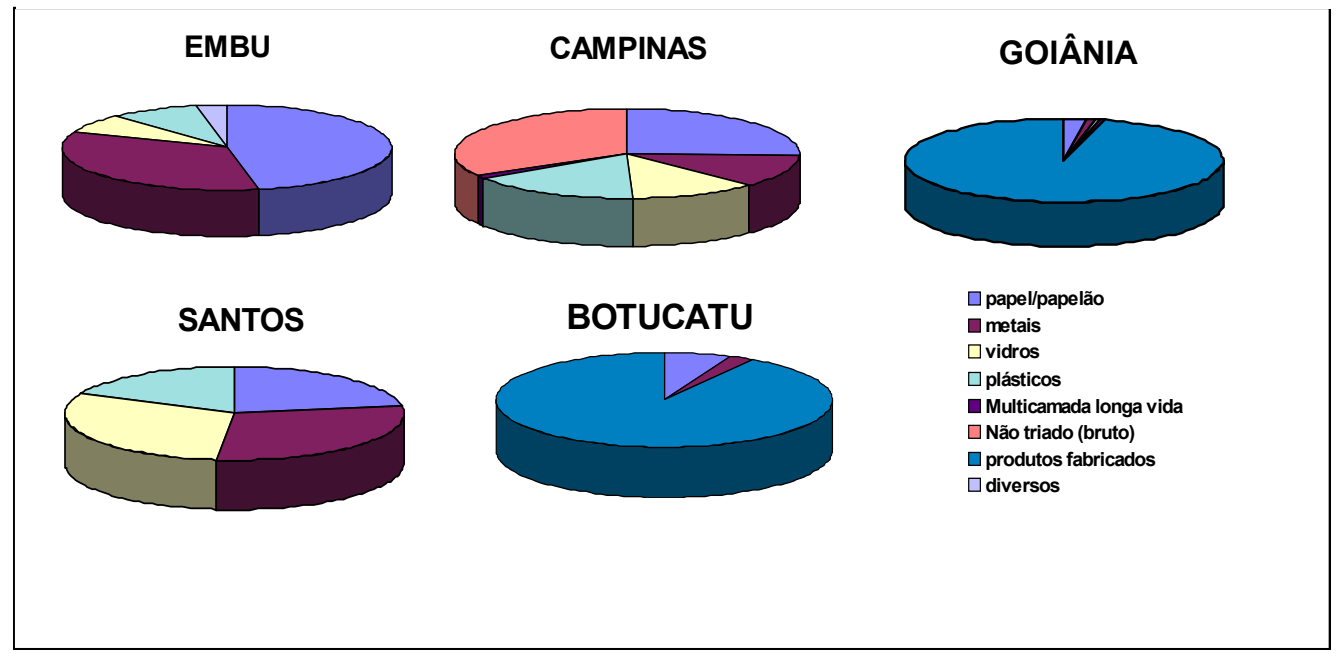


sustentação econômica das iniciativas. Por serem gerados de forma mais concentrada e em quantidades maiores, estes resíduos oferecem boas condições de qualidade de material e de economia de escala, e a incorporação dos resíduos domésticos a eles contribui para viabilizar os programa de coleta seletivas.

A falta de acesso a financiamentos e a taxação dos produtos reciclados ainda foram apontados como obstáculos importantes para a ampliação das ações de reciclagem, principalmente pelos comerciantes e industriais. Também, foram apontadas diversas vezes situações de inadimplência, reflexo da atual situação econômica do país. Os sucateiros entrevistados ressaltaram que esperavam que a partir de março a situação melhorasse.

Destaca-se que no município de Santos quase todos os preços obtidos são abaixo da média brasileira, refletindo-se também no menor valor médio por tonelada comercializada entre os municípios estudados. Isto se deve provavelmente ao pequeno número de grandes intermediários, que ditam os preços na baixada santista, já que a qualidade do material limpo e prensado observada é similar à dos demais programas. Faz-se necessário, neste município, desenvolver parcerias comerciais e concorrências fora do município para melhorar a viabilidade econômica do programa, que além disso é o mais caro para as prefeituras envolvidas.

Tabela 8.4. Preços de venda médios dos materiais recicláveis em diversos municípios, em $\mathrm{R} \$$ /t.

\begin{tabular}{c|c|c|c|c|c|c}
\hline MATERIAL & CAMPINAS & EMBU & $\begin{array}{c}\text { GOIANIA } \\
(*)\end{array}$ & SANTOS & BOTUCATU & $\begin{array}{c}\text { BRASIL } \\
(* *)\end{array}$ \\
\hline Papel / Papelão & 44 & 87 & 40 & 13 & 20 & 118 \\
Papel & & & & & & 166 \\
Papelão & & & 114 & & 30 & \\
Sucata metálica & 29 & 83 & & 10 & & 30 \\
Ferrosa & 815 & 714 & & 350 & & 613 \\
Não ferrosa & & & & & & \\
Vidros & 30 & 53 & 52 & 42 & & \\
Plásticos & 193 & 91 & 120 & 70 & 70 & 173 \\
PET & 103 & 80 & 20 & 30 & & 111 \\
Outros & 40 & - & - & & - & 34 \\
Longa vida & 27 & - & - & & - & \\
Sem triar &
\end{tabular}

(*) Não inclui materiais processados

(**) Média aritmética simples de valores referidos em CEMPRE (1998a, b, c) 
No município de Embu a COOPERMAPE obtém o melhor rendimento médio por tonelada. Isto se deve à parceria com a RIPASA, que paga à cooperativa o mesmo preço que paga aos demais aparistas, que entregam o material enfardado. $\mathrm{O}$ custo adicional por aceitar material sem enfardar é assumido pela empresa como insignificante, em função de que o material comprado da cooperativa representa pouco em relação ao total de aparas utilizadas. A COOPERMAPE corre, entretanto, um risco relativamente alto. No caso de a empresa retirar seu apoio, o faturamento cairia drasticamente, podendo provocar graves conseqüências. É necessário portanto buscar novos parceiros para este e outros materiais, de forma a ser menos dependente de um único comprador, conforme recomendam WELLS e col. (1995).

A sucata ferrosa é vendida em Embu a um bom preço. A coleta cata-treco de objetos de grande volume - realizada em conjunto com a coleta seletiva contribui para isso. Em compensação, o preço obtido pelos plásticos é baixo, principalmente devido ao baixo grau e qualidade de separação e à falta de prensagem, o que inviabiliza o transporte para compradores mais distantes que estivessem dispostos a pagar preços melhores.

Em Campinas destacam-se os bons preços obtidos pela sucata não-ferrosa e pelo PET, resultado de acordos comerciais. É também o único dos programas que vende embalagens longa vida, o que foi possibilitado pelas parcerias estabelecidas pela Tetra Pak com outras empresas e com o próprio DLU.

A sazonalidade dos preços dos materiais recicláveis foi confirmada por quase todos os entrevistados, entretanto nenhum deles cogitou parar suas atividades em função desta sazonalidade. Também houve referências, especialmente nos mercados de papel e plásticos, a variações dos preços dos recicláveis ao mercado de materiais virgens. Neste ponto, o efeito da globalização tem sido disponibilizar material virgem barato, dificultando a utilização de recicláveis.

No âmbito internacional, COOPER J (1998) relata as flutuações extremas a que o mercado de recicláveis está sujeito, por causa da situação econômica geral e 
mesmo por causa de novas legislações, que chegaram a causar a inundação do mercado com materiais recicláveis, causando queda do preço dos mesmos, inviabilizando a atividade de coleta. A autora relata ainda que, devido à variação dos preços dos recicláveis, muitos municípios americanos estão reavaliando seus programas de coleta, e às vezes até interrompendo totalmente, como no caso de Washington DC.

O estabelecimento de parcerias comerciais poderia, dentro de certos limites, amortecer os efeitos desta sazonalidade. Mas o uso de instrumentos econômicos de incentivo e desincentivo por parte do governo poderiam favorecer a elevação dos preços e melhorar a viabilidade da reciclagem a longo prazo, sendo portanto indispensáveis políticas públicas neste sentido, para aumentar as quantidades de resíduos efetivamente recicladas. Neste caso pressões da sociedade e dos próprios setores produtivos envolvidos são necessárias para a efetiva utilização desses instrumentos econômicos.

Essa ação reguladora do governo, ainda não observada no Brasil, está num dos focos de políticas de resíduos sólidos em outros países. COOPER MH (1998) confronta duas posições opostas sobre a obrigatoriedade de reciclagem e do estabelecimento de metas e cotas obrigatórias das quantidades recicladas. Em primeiro lugar, há os que são contra; dizem que a obrigatoriedade distorce os mercados de materiais recicláveis, impedindo seu desenvolvimento no longo prazo. Essa posição está ligada às políticas baseadas no mercado como mecanismo eficiente para estabelecer a distribuição ótima dos recursos. Ainda segundo o autor, dizem também que há muitos materiais cuja reciclagem não é economicamente viável, e aí é o ponto onde as exigências governamentais entram e canalizam recursos para reciclagem que poderiam ser utilizados em atividades mais produtivas. Do outro lado, ainda segundo o autor, posicionam-se aqueles que defendem que as obrigatoriedades ajudam a iniciar os mercados.

No momento em que se reconhece que é importante incluir aspectos ambientais às decisões econômicas, não se pode utilizar as regras do mercado sem 
intervenção, já que são conhecidas as distorções que contribuíram, inclusive, para inúmeros prejuízos ambientais que vemos hoje. Tais regras só poderão ser integralmente utilizadas se for possível quantificar economicamente todos os aspectos ambientais envolvidos.

Nos programas estudados, não há sinais de intervenção firme estatal no mercado, na medida em que não há incentivos para as indústrias e não há fixação de metas obrigatórias ou responsabilização de fabricantes e comerciantes, que são tipicamente os sinais mais fortes de intervenção. Em nível estadual e federal, existem projetos de Políticas de Resíduos Sólidos que caminham no sentido de estabelecer alguns incentivos. (SMA 1998b; 1998c).

\subsubsection{Viabilidade Econômica}

Num sistema envolvendo diversos atores, a coleta seletiva precisa ser viável para cada um deles. Do ponto de vista dos sucateiros entrevistados, a sua atividade de comércio de materiais recicláveis é viável por ser lucrativa, apesar da sazonalidade dos preços e das dificuldades momentâneas de inadimplência. Vários deles tinham, inclusive, planos para expansão e para executar também etapas de valorização dos materiais: no caso dos plásticos, realizar a lavagem e moagem dos mesmos; no caso das sucatas metálicas, trabalhar com enfardamento de grandes quantidades para vender diretamente a siderúrgicas.

Do ponto de vista das prefeituras, o primeiro critério que é geralmente utilizado para avaliar a viabilidade econômica de um programa de coleta seletiva e reciclagem é a comparação dos custos deste programa por tonelada de resíduo coletada com o custo da coleta regular. Uma análise rápida (Tabela 8.5) confirma que na maioria dos casos, por este critério, não valeria a pena a execução da Coleta Seletiva, uma vez que os custos são em média 2,5 vezes mais altos que os custos da solução convencional. Por outro lado, considerando-se apenas os programas com participação das prefeituras, na maioria dos casos os custos para as prefeituras são 
três vezes maiores que o custo da solução convencional, já bem abaixo da previsão de oito vezes mais caro, mostrada por CEMPRE (1999).

Do ponto de vista dos catadores e cooperados, em Embu eles parecem mais satisfeitos, porque mesmo que não ganhem significativamente mais do que ganhavam trabalhando no lixão. compreendem que o ganho maior foi de qualidade de vida. Em Goiânia nota-se um clima menos otimista, porque a cooperativa vem enfrentando dificuldades como erros de projeto, falta de colaboração da COMURG e outros contratempos.

A análise custo-benefício do ciclo completo da reciclagem é extremamente complexa, e também não há critérios padronizados para a avaliação em todas as suas dimensões. Dos programas estudados, dois (Embu e Campinas) mostraram durante

Tabela 8.5. Comparação com a coletar regular municipal - Aspectos econômicos do ponto de vista da Prefeitura Municipal

\begin{tabular}{|c|c|c|c|c|c|c|}
\hline \multirow[t]{2}{*}{$\begin{array}{l}\text { Município / } \\
\text { Programa }\end{array}$} & \multicolumn{3}{|c|}{$\begin{array}{l}\text { Custos da Coleta regular } \\
\text { (custo evitado em US\$/t) }\end{array}$} & \multirow{2}{*}{$\begin{array}{c}\text { Faturamento da } \\
\text { prefeitura } \\
\text { US\$ / t } \\
\text { vendida }\end{array}$} & \multirow{2}{*}{$\begin{array}{c}\text { Custo para } \\
\text { prefeitura } \\
\text { Coleta seletiva e } \\
\text { triagem } \\
\text { (US\$/t vendida, } \\
\text { considerando } \\
\text { ganho com venda) }\end{array}$} & \multirow{2}{*}{$\begin{array}{c}\text { Custo } \\
\text { adicional } \\
(\%)\end{array}$} \\
\hline & $\begin{array}{l}\text { Coleta e } \\
\text { transporte }\end{array}$ & Aterro & Total & & & \\
\hline Embu & 51,43 & 23,51 & 74,94 & 0,00 & 170,09 & 117 \\
\hline Campinas & 41,42 & 16,56 & 57,98 & 37,15 & 607,77 & 872 \\
\hline Goiânia & 22,67 & 7,25 & 29,92 & 0,00 & 22,67 & -24 \\
\hline Santos & 59,13 & 5,60 & 64,73 & 26,73 & 424,17 & 529 \\
\hline Botucatu & 38,93 & 11,88 & 50,81 & 0,00 & 0,00 & 0 \\
\hline Belo Horizonte & 34,80 & 4,95 & 39,75 & 0,00 & 129,80 & 210 \\
\hline Porto Alegre $(*)$ & 43,40 & 13,25 & 56,64 & 0,00 & 98,70 & 68 \\
\hline
\end{tabular}

as entrevistas avaliações quantitativas do custo-benefício do investimento em coleta seletiva. A prefeitura de Embu procurou inclusive quantificar benefícios sociais, chegando a um balanço equilibrado com benefícios ligeiramente maior que custos (BENSEN 1998).

Um dos itens de custo que precisa tem que ser considerado é o custo do terreno do aterro. Como estes terrenos normalmente são da própria prefeitura, ou doados, o seu preço raramente é incluído nos custos de aterro, e mesmo quando há 
uma desapropriação, o valor da fração de terreno ocupada por cada tonelada de resíduo disposta não é geralmente incluído, porque os custos divulgados são apenas os operacionais, e este é considerado de investimento. Aos poucos este tipo de análise deve ser incorporado aos projetos, e com isto a conclusão de que a coleta seletiva é economicamente viável inclusive do ponto de vista da prefeitura deve aparecer, ao menos em alguns casos. Mas para isto é fundamental que haja avanços nas pesquisas, que as informações sejam divulgadas e que sejam estabelecidos critérios para valoração de benefícios difíceis de quantificar, como a melhoria da qualidade de vida da população em geral e de grupos específicos, como catadores.

A viabilidade econômica depende também de um planejamento correto. Segundo COOPER MH (1998) geralmente os programas implantados nos Estados Unidos cometeram erros na priorização das áreas atendidas, e por isso são muito caros. Essa ênfase no erro de priorização é bastante importante, porque certas áreas podem ter na composição dos resíduos domésticos frações maiores ou menores de recicláveis. Em programas como Embu e Goiânia, a prioridade da coleta seletiva está, ao menos em parte, nos bairros de baixa renda caracterizados por casas térreas, pela necessidade de se proteger certas áreas com riscos ambientais mais presentes. Nesses casos a eficiência de coleta tende a ser mais baixa quando comparada aos programas que atendem áreas mais verticalizadas, como em Santos e Porto Alegre. Portanto, se a preocupação de quem está promovendo o programa de coleta seletiva for maximizar a quantidade de resíduos reciclados para fins de ganhos ambientais e de espaço em aterro sanitário ao menor custo possível, as áreas a serem priorizadas são as áreas de maior densidade demográfica e poder aquisitivo. Por outro lado, se a preocupação maior for mudar os hábitos das populações de áreas com características de risco ambiental, como em Embu e Goiânia, o programa deve ser encarado, principalmente nos primeiros anos, mais como um investimento em Educação Ambiental que como uma solução para a redução dos resíduos em larga escala, principalmente para efeito de alocação de recursos. Posteriormente, após a solidificação do programa, ele pode ganhar impulso e viabilidade econômica. 
Ainda de acordo com COOPER MH (1998) muitos especialistas argumentam que ainda é cedo para avaliar o potencial total do mercado de recicláveis pelo espaço de apenas uma década de atividade significativa de coleta seletiva porta-a-porta - no caso, nos Estados Unidos. Assim como hoje há tecnologia para reciclar materiais que anteriormente não era possível, no futuro novos materiais se tornarão economicamente recicláveis. O mesmo se aplica ao Brasil, e somente com a aplicação de políticas públicas compatíveis haverá o desenvolvimento tecnológico para progressivo aproveitamento dos materiais encontrados nos resíduos sólidos domésticos.

Portanto, para que programas de coleta seletiva e reciclagem sejam viáveis, é preciso estabelecer ações conjuntas entre órgãos do governo para planejar com competência, motivar e envolver a população e os empresários locais. Essa perspectiva de atuação político-institucional pode contribuir para a viabilização econômica de tais programas.

\subsection{Dimensão político-institucional}

\subsubsection{Envolvimento das instituições nos programas}

Nesta seção buscou-se ressaltar as vantagens obtidas e as contribuições de cada instituição, e as principais conseqüências para o funcionamento do programa, comentando e discutindo os aspectos considerados mais relevantes nas parcerias em cada programa.

\subsubsection{Embu}

Em Embu a parceria entre os catadores da COOPERMAPE e a Secretaria Municipal do Meio Ambiente é a parceria central. A iniciativa da prefeitura municipal de retirar os catadores levou à formação da cooperativa. 
Cabe à Prefeitura Municipal fornecer apoio material, técnico e de fortalecimento humano aos cooperados, ao mesmo tempo em que eles executam com sua mão-de-obra um serviço público de interesse do município. Esta parceria tem características de suporte material porque a prefeitura cede veículos e área para trabalho, e a cooperativa cede sua mão-de-obra. Como ponto positivo pode-se destacar também a busca da Secretaria de Meio Ambiente por apoios para educar e treinar os cooperados, além de contatos para financiamentos.

Entre as vantagens obtidas pela administração municipal, está a diminuição dos custos de mão-de-obra de coleta, triagem e comercialização. A verba obtida recentemente para o projeto do centro de triagem na área do aterro sanitário deve contribuir ainda mais para essa diminuição. A manutenção dos equipamentos em adequadas condições de funcionamento é fundamental, e é uma das funções assumidas pela Prefeitura que vem dependendo fundamentalmente de verbas orçamentárias.

Por sua vez, os cooperados têm como vantagem melhores condições de trabalho, uma vez que têm equipamentos à sua disposição. Entretanto, o desenvolvimento profissional dos cooperados ainda é visto por alguns entrevistados, especialmente sucateiros, como relativamente lento. Nota-se efetivamente que a Cooperativa ainda não é administrativamente autônoma, e que alguns aspectos da qualidade dos materiais vendidos e da valorização dos mesmos ainda não foram incorporados no trabalho dos cooperados. Conclui-se que a capacitação dos cooperados como empresários ainda não se consolidou, devendo permanecer o apoio da prefeitura por mais tempo.

Observou-se em campo que por vezes era realizada coleta em empresas em detrimento da coleta domiciliar. Com o agravamento dos problemas de manutenção dos veículos, as falhas da coleta nos bairros em relação à programação causaram queda acentuada da adesão da população em algumas regiões: conseqüência grave para o bom andamento do programa. Seria necessário um maior compromisso da cooperativa com a sua contrapartida para a prefeitura, no sentido de manter a 
prioridade da coleta nos bairros, ao mesmo tempo que teria que ser priorizada, por parte da administração municipal, a manutenção dos veículos. Isso contribuiria para manter o clima de confiança necessário à continuidade da parceria.

\subsubsection{Goiânia}

A parceria da SGC com a comunidade dos cinco bairros atendidos, posteriormente consolidada na parceria com a cooperativa é central no programa. Após a oficialização da cooperativa, com o registro da mesma e eleição de diretoria, um contrato de comodato liga as duas entidades numa parceria de concessão de equipamentos para geração de renda para os cooperados, desde que o funcionamento da cooperativa garanta o alcance social nos moldes pretendidos pela SGC.

Por seu lado, a SGC viabiliza desta forma seu objetivo de atuação em projetos de desenvolvimento. A instituição assume para si a responsabilidade de buscar financiamento e oferecer o necessário apoio aos cooperados. Neste caso, os moradores dos bairros atingidos nunca tinham tido contato com a atividade de coleta e reciclagem de lixo. Portanto um apoio mais forte nas atividades de coleta e triagem foi necessário, além do treinamento necessário para operar os equipamentos industriais.

Do ponto de vista do investimento para a implantação, a iniciativa da SGC de submeter o projeto para financiamento federal foi fundamental, demonstrando a equipe capacidade para captar recursos tanto da área social - Ministério da Previdência e Assistência Social - quanto da área ambiental - Ministério do Meio Ambiente - para um projeto de desenvolvimento sustentável. Este caminho poderia ser mais explorado pelas instituições promotoras dos projetos, e mais apoiado também pelos governos nos três níveis.

Dentre os casos estudados, esta é a uma das iniciativas que promove a capacidade local para o processamento dos materiais, ao implantar uma extrusora de 
plásticos, a produção de telhas e a compostagem. A presença do processamento garante à cooperativa a maior parte dos ganhos.

Entre os problemas que foram apontados está a dificuldade em conseguir que a SANOESTE cumprisse cláusulas contratuais, como reformar equipamentos com problemas de projeto. Uma das consequências graves foi o atraso no funcionamento efetivo de processos e equipamentos, e consequentemente na viabilização econômica da usina. Além disto, ao observar os equipamentos adquiridos e sua operação foram notadas diversas falhas com relação ao processo de trabalho e algumas com relação à segurança dos operadores, cuja solução se revelou bastante lenta. Por mais que tenha havido dificuldades burocráticas na época da entrega oficial dos equipamentos, teria sido necessário um acompanhamento mais próximo por técnicos e engenheiros, de forma a evitar dificuldades futuras.

Outra dificuldade foi o cumprimento por parte da prefeitura municipal, através da COMURG, de uma das suas atribuições no programa, que seria o pagamento à cooperativa pela coleta e processamento dos resíduos. Esta dificuldade surgiu a posteriori, quando a administração municipal questionou a validade do acordo entre a Cooperativa e a COMURG, quando do pagamento do valor referente ao mês de novembro - primeiro mês em que a cooperativa realizou também a coleta regular de resíduos sólidos domésticos nos cinco bairros. Do ponto de vista de custos, não haveria prejuízo para a prefeitura, pelo contrário, já que a prefeitura pagaria à empreiteira o mesmo valor para a coleta, acrescido ainda do valor da disposição final no aterro sanitário.

No desenrolar dos acontecimentos, as idéias de alguns profissionais do Instituto Dom Fernando não tiveram apoio da direção da Sociedade Goiana de Cultura, o que culminou com o afastamento de alguns dos profissionais que haviam participado desde o início do projeto. As necessárias substituições devem ter contribuído também para o atraso da solução de questões gerenciais e das adaptações necessárias ao projeto original, e portanto também para o atraso do aumento na auto- 
sustentação da cooperativa. Também se afastaram, motivados talvez por essa demora, alguns dos cooperados originais.

\subsubsection{Campinas}

O trabalho conjunto do DLU com o FUSSCAMP é uma parceria estabelecida em legislação. Ao DLU cabe operar a coletados resíduos e a sua triagem. Seus pontos fortes são a disponibilidade de pessoal técnico capacitado em gerenciamento de resíduos e a disponibilidade de equipamentos, mas não tem estrutura para comercializar os resíduos. O FUSSCAMP, ao comercializar os resíduos, obtém recursos para atividades filantrópicas específicas, para os quais não haveria outras fontes.

Em 1998 os problemas de quebra de equipamento que o DLU enfrentou limitaram sobremaneira a quantidade de resíduos efetivamente recicladas, prejudicando bastante a arrecadação para o FUSSCAMP. Este problema não pode ser solucionado dentro da parceria DLU/FUSSCAMP, mas foi solucionado buscando locais e empresas alternativas que se dispusessem a realizar a triagem, as chamadas "unidades descentralizadas". São novas parcerias, que se têm se traduzido em boas perspectivas, contribuindo inclusive para o desaparecimento progressivo das limitações operacionais da triagem, mudando o gargalo do processo para a coleta

O envolvimento institucional de comunidades organizadas é um dos aspectos mais positivos do programa. Ressalte-se que em 1998 o DLU tinha dificuldades inclusive para coletar em escolas que estavam se propondo a realizar coleta seletiva.

\subsubsection{Santos}

As modificações que vêm sendo observadas no modelo de gestão de resíduos sólidos em geral, e da coleta seletiva em particular, devem-se pelo menos em parte à mudança do grupo partidário no governo que ocorreu de 1996 para 1997. 
Observa-se, em primeiro lugar, a diminuição da ajuda oferecida aos carrinheiros e as limitações impostas ao trabalho deles. A interrupção do programa dos trabalhadores ecológicos, o enfraquecimento da participação da SEAC Secretaria de Ação Comunitária e o afastamento da Secretaria da Saúde apontam para novos rumos.

Estão desaparecendo as parcerias que havia antes, e estabelecendo-se novas formas de operação como o contrato entre a PRODESAN e a TERRACOM, , com uma tendência para haver ainda novos contratos na área de resíduos sólidos. Com estes contratos, a administração municipal se desonera de salários e encargos sociais e da manutenção dos equipamentos. Corre o risco, entretanto, de que os carrinheiros sem apoio parem suas atividades, o que aumentaria a quantidade de resíduos destinadas ao aterro sanitário, ou de aumento da quantidade coletada pela TERRACOM, o que aumentaria os custos na proporção do material coletado.

A TERRACOM é contratada para efetuar a coleta seletiva porta-a-porta e recebe o pagamento por tonelada coletada. Se o lucro por tonelada de coleta seletiva realizada for maior que o lucro com a coleta regular, pode haver um interesse da própria empresa em aumentar a participação da população e em fazer ela própria investimentos em Educação Ambiental, principalmente nas áreas onde o potencial de coleta de materiais recicláveis é maior. Por outro lado, o aumento de custos para a Prefeitura Municipal neste caso é diretamente proporcional à participação da população, ao invés de ocorrer uma queda dos custos devido à economia de escala. Conforme foi demonstrado no item anterior, o valor pago à TERRACOM é bastante alto em relação ao custo possível quando são adotadas outras estruturas, e não tem perspectiva de redução, já que há um contrato assinado que estabelece este preço. Outros modelos iniciam-se com custos relativamente altos, mas a perspectiva de longo prazo é que os custos se reduzam, conforme ficou demonstrado na análise dos custos. Deste modo, conclui-se que a administração municipal deveria repensar o modelo adotado, buscando na sua própria experiência e nas experiências de outros municípios, buscar formas mais baratas de fazer a coleta seletiva, com a participação dos catadores. Uma das alternativas seria o modelo de Embu, em que a mão-de-obra 
da coleta é também de cooperados. Alternativamente, poderia rever o contrato com a operadora, buscando um modelo em que ela assumisse os riscos e os lucros da coleta seletiva, sem onerar exageradamente o município, como acontece hoje. É necessária, neste caso, uma nova mudança no modelo utilizado em Santos.

\subsubsection{Botucatu}

A parceria estabelecida entre o Departamento de Ciências Ambientais e a Ação da Cidadania de Botucatu funcionou durante um tempo relativamente curto porque a Ação da Cidadania não tinha pessoal disponível para administrar as operações de retirada e a comercialização do material reciclável.

Além disso, nota-se que os valores arrecadados são bastante baixos. Esta situação se deve principalmente à falta de indústrias dispostas a processar o material na região. Neste ponto é importantíssima a iniciativa de desenvolvimento de tecnologia e de implantação de equipamentos com capacidade industrial na UNESP. Da mesma forma, as parcerias da Universidade com empresas sediadas na região, como já acontece, pode impulsionar a viabilização de investimentos na industrialização dos materiais na própria região. Seria importante poder ampliar estes esforços para a reciclagem de outros materiais.

Deveria haver, por parte do poder público, incentivos para tais investimentos. Pode ser que isto não seja viável para todos os materiais, em função de que alguns tipos de instalação poderiam exigir um porte relativamente grande em relação ao tamanho dos municípios e à quantidade de resíduos recicláveis gerados na região. Seria interessante, inclusive, que houvesse uma articulação entre prefeitos, talvez com intervenção do Estado, para que fossem feitos estudos neste sentido.

\subsubsection{Comentários gerais sobre a articulação inter-institucional}

Todos os programas têm uma instituição que tomou a iniciativa e que gere o programa. Praticamente todas as outras entidades envolvidas são trazidas a participar 
por meio de um contato desta instituição. Com exceção das cooperativas que foram formadas por incentivos externos, no início dos programas, todas as outras instituições já existiam, executavam suas atividades normalmente e não dependiam do programa como atividade essencial para atingir seus objetivos.

Este fato mostra que os programas implementados têm levado em conta, em geral, as estruturas existentes. Isto tem um ponto positivo na medida em que agrega atores sociais em torno da iniciativa e pode reduzir custos de implantação e operação.

Por outro lado, para a maioria dos entrevistados o programa não constitui atualmente elemento essencial de suas atividades. Como conseqüência, para que participem do programa, é preciso que tenham uma percepção positiva do mesmo, e que baseados nesta percepção se disponham a manter os compromissos necessários.

A maioria dos entrevistados considera que o programa vai bem, apesar de identificarem alguns problemas e dificuldades. Diversos deles fundamentaram sua expectativa otimista na necessidade do uso da reciclagem como forma de minimização de resíduos e da crescente participação da população.

Entretanto, que estão presentes também expectativas negativas quanto ao futuro do programa, que expressam geralmente a apreensão quanto à continuidade administrativa. Isto ocorre principalmente no município de Santos, onde a mudança do grupo exercendo o poder na Prefeitura Municipal trouxe mudanças nas políticas de governo, com conseqüentes mudanças no gerenciamento do programa de coleta seletiva, de modo a despertar essa percepção pessimista em alguns participantes. O medo das mudanças políticas futuras apareceu também em outros programas. Por outro lado, a dificuldade de adaptação de determinadas instituições e profissionais a situações novas foi relatada, principalmente em Goiânia.

Nas entrevistas foram citadas, dentre as relações inter-institucionais, 96 entidades, o que dá uma média de 20 por programa. Entre as instituições citadas, estão 38 órgãos públicos e autarquias, 40 empresas e 18 ONGs. Foram citados 
diversos tipos de relações inter-institucionais, entre as quais, no entender dos entrevistados, 39 parcerias. Isto mostra que, à medida em que a teia de apoios, parcerias e outros envolvimentos vai crescendo, a complexidade da administração do sistema também cresce.

Entre os principais parceiros ausentes que poderiam colaborar foram citados órgãos estaduais e federais de meio ambiente e de financiamento. A implementação de políticas de resíduos sólidos em nível nacional e estadual deve levar em conta que estes apoios seriam, se bem articulados, amplamente aceitos por aqueles que já estão envolvidos nos programas de coleta seletiva e reciclagem e que desejam ampliar suas atividades. Os órgãos de meio ambiente em nível estadual e nacional, em particular, têm uma tarefa importantíssima que é de articular as políticas de resíduos sólidos com as demais políticas, principalmente econômica, industrial, social e de ciência e tecnologia. Por meio desta articulação podem ser removidas as barreiras que estão fora da alçada do poder local, mas que estão intimamente ligadas à ação local nos programas de coleta seletiva e reciclagem. Não se pode esquecer também as imensas dívidas que têm a maioria dos municípios. Sem o equacionamento destas dívidas, as administrações municipais ficam impossibilitadas de investir elas próprias.

As parcerias podem ser formalizadas, por meio de contratos ou convênios. Exemplos disto são a cessão de equipamentos em comodato da SGC para a COOPREC e da Prefeitura de Santos para a TERRACOM. Mas em muitos casos ocorrem apoios e parcerias informais, como a disponibilização de caçambas e contêineres, a doação de material gráfico para Educação Ambiental e certas transferências de tecnologia, cessão de informações, análises laboratoriais e outras, principalmente contatos pessoais. Isto não ocorre, geralmente, nas parcerias centrais, mas sim em apoios auxiliares que contribuem para a viabilização do projeto em etapas intermediárias ou para superação de dificuldades momentâneas. 


\subsubsection{Principais dificuldades e soluções propostas}

As dificuldades de ordem econômica citadas como inadimplência, impostos, preços de mercado e falta de verba fazem parte da realidade do País. Há entretanto pouca mobilização coletiva para solução destes problemas. Não foram citadas nas entrevistas ações tomadas por associações de indústrias de reciclagem ou por associações de sucateiros, junto ao governo, para redução de impostos. Alguns entrevistados inclusive criticaram a atuação de certas associações e reconheceram a formação de cartéis para fixação de preços. Abre-se um bom campo de discussão neste sentido no momento em que se inicia a elaboração do Programa Brasileiro de Reciclagem (MICT 1998). Os próprios municípios, responsáveis pelo gerenciamento dos resíduos sólidos domésticos, poderiam promover ações no sentido de criar seus próprios incentivos e de buscá-los junto aos níveis federal e estadual.

A dificuldade de se envolver a comunidade também foi citada por vários entrevistados. Este envolvimento envolve mudanças na atitude e nas práticas cotidianas dos munícipes. A existência de programas de Educação Ambiental que dêem suporte ao trabalho de coleta seletiva, e que ao mesmo tempo se utilizem dele como forma de atuação é fundamental para o sucesso de qualquer programa. A participação de instituições multiplicadoras como escolas, igrejas e associações de bairros tem um papel fundamental, e na maioria dos casos foram citados como

apoios já existentes. Entretanto, nos estudos de caso foram notados casos de descompasso entre a coleta e a atuação da escola. Em Campinas, o DLU tinha dificuldades para atender a escolas que desejavam ter coleta seletiva; em Embu escolas atendidas não aproveitavam todo o potencial do serviço oferecido para realizar Educação Ambiental com os alunos.

Por outro lado nos locais onde não há coleta seletiva, é importante que haja um trabalho intenso de Educação Ambiental que conscientize a comunidade da importância da questão dos resíduos sólidos e que a leve a cobrar dos governantes as ações para implementação e ampliação dos programas, ou à implantação de iniciativas independentes. Este papel cabe às ONGs. 
Tem também um papel fundamental a comunicação ambiental, no sentido da veiculação de mensagens e divulgação dos programas na mídia local falada e impressa. Eventualmente os produtos fabricados a partir dos materiais reciclados podem se ressentir da falta de divulgação e propaganda, como é o caso das telhas de Goiânia, por exemplo.

No grupo das dificuldades tecnológico-operacionais se destaca a questão dos equipamentos ausentes ou inadequados, mostrando que vários dos entrevistados encontram-se insatisfeitos com os equipamentos disponíveis. A vantagem de modelos intensivos em mão-de-obra, como aqueles baseados em catadores, é de que os equipamentos podem ser adquiridos aos poucos, como foi o caso Ressalta-se, por um lado a importância de investimentos que mantenham tais equipamentos atualizados tecnologicamente e da presença de recursos para manutenção dos mesmos, garantindo a continuidade dos trabalhos. Por outro lado, a necessidade de se trabalhar soluções de baixo custo e que exijam poucos equipamentos, especialmente nas etapas iniciais dos projetos.

A maioria das dificuldades apontadas na literatura e descritas em outros estudos de caso são reconhecidas e identificadas pelos entrevistados, o que mostra que já existe um conhecimento significativo a respeito de coleta seletiva. Entretanto, os preconceitos estão às vezes arraigados e é necessária mais ênfase na divulgação das soluções encontradas. Apesar de que cada localidade enfrenta situações e dificuldades particulares, certamente há idéias que podem ser adaptadas a outras situações. Por outro lado, a presença sistemática de certas dificuldades pode gerar pressões para o surgimento de novos apoios e elementos nas políticas públicas.

Há que se reconhecer duas situações: uma em que a solução do problema é conhecida, em uma determinada experiência, e não divulgada. Muitas parcerias também surgem entre pessoas que já se conheciam de outros trabalhos, o que ressalta a importância da divulgação dos trabalhos e experiências para que outros profissionais possam aproveitá-las. O conhecimento dessas experiências pode 
também facilitar o trabalho de convencimento dos pares sobre a importância e da viabilidade dos programas.

Outro caso ocorre quando a solução é conhecida, porém é de difícil articulação política. Chama a atenção que 15 das 25 soluções propostas pelos entrevistados estão ligadas a fatores humanos e políticos. Isto reforça o conceito de que deve-se dedicar uma parte significativa dos esforços, talvez a maior parte deles e os mais iniciais, neste campo (Figura 8.11). A partir de avanços nestas áreas seriam alavancadas as soluções de ordem operacional e tecnológica porque sem o envolvimento das pessoas, pouco vale ter equipamentos de última geração ou dinheiro em caixa. E enfim, as pessoas envolvidas e capacitadas acabam por conseguir, com trabalho, verbas e equipamentos para seus projetos.

Figura 8.11. Esforços iniciais para a implementação de programas de coleta seletiva, com foco inicial na formação de recursos humanos

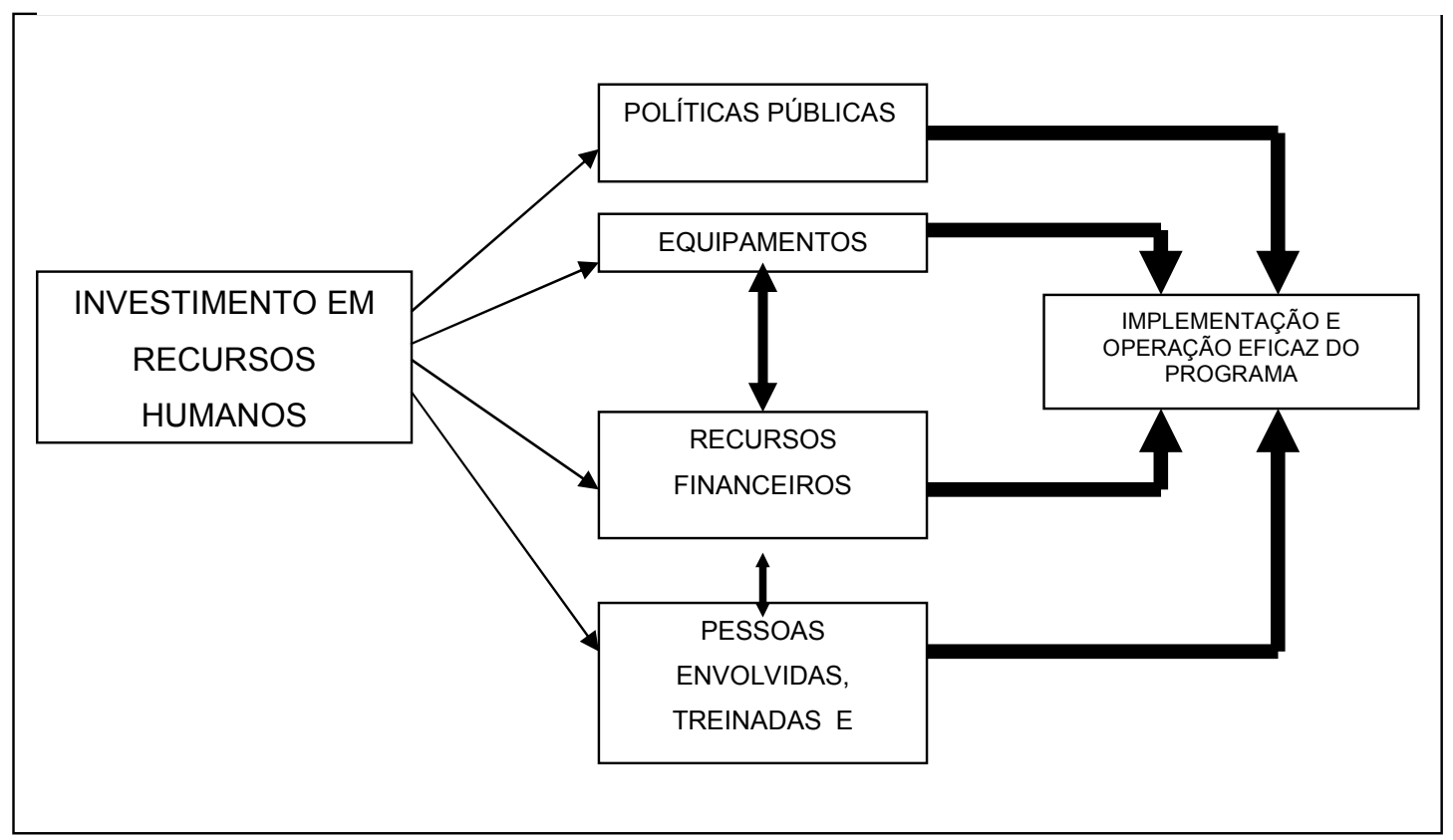

No caso dos técnicos que trabalham nos projetos, é preciso que sejam capazes de trabalhar em estruturas flexíveis e para trabalhar dentro de posturas participativas modernas, com atenção para a capacidade para se relacionar com a mão-de-obra pouco qualificada que trabalha na coleta, triagem e processamento dos materiais. Coordenadores de programas relataram dificuldades neste sentido. Além disso, há a 
dificuldade dos prazos relativamente longos para retorno, para os quais os profissionais têm que ter paciência.

Parcerias como emprego para deficientes, para presos e mesmo cooperativação de catadores, que são iniciativas extremamente louváveis do ponto de vista social, podem esbarrar na baixa produtividade e qualidade do seu trabalho, especialmente se a rotatividade for alta, dificultando a viabilização econômica dos trabalhos.

No caso das cooperativas, o processo de adaptação dos catadores a novos sistemas, como o recebimento de dinheiro não mais diariamente, mas em períodos mais longos, e também a necessidade de geração de capacidade empreendedora e administrativa foram considerados importantes. Segundo a percepção de alguns entrevistados, o processo poderia ter ocorrido mais rapidamente, mas na prática ocorre que este é um processo realmente demorado. Os exemplos de Embu e Goiânia mostram claramente que é preciso apoio de longo prazo às associações e cooperativas, e cabe à instituição que as apoia ser flexível ao longo do processo e retirar seu apoio de maneira gradual, acompanhando os avanços obtidos. Este fator precisa ser levado em conta no momento em que se programa os gastos com pessoal de apoio no projeto, para que a verba seja suficiente no longo prazo e para tentar diminuir a evasão de catadores e cooperados do programa, o que sempre acontece.

\subsection{Dimensão sócio-ambiental}

A dimensão sócio-ambiental é na verdade o resultado das ações nas outras dimensões. É nessa dimensão que se revelam os aspectos relativos à qualidade de vida. Puderam ser observados aspectos ambientais, como os materiais recuperados, aspectos de saúde pública como os cuidados com a proliferação de vetores e os aspectos de participação da comunidade e de Educação Ambiental. 


\subsubsection{Os materiais recuperados dos resíduos coletados.}

$\mathrm{Na}$ maioria dos programas o grupo de materiais papel/papelão é o mais representativo em termos do peso dos resíduos coletados (Figura 8.12). Em Goiânia a COOPREC tem preferência em coletar este material porque a fabricação das telhas é uma das atividades mais rentáveis entre aquelas por ela realizada, e em Embu essa preferência se deve ao bom preço pago pela RIPASA pelos papéis. Em Embu a alta proporção de sucata ferrosa deve-se à coleta de móveis e eletrodomésticos efetuada juntamente com a coleta seletiva. Em Botucatu há um programa específico para reciclagem de papel na Universidade.

Em Porto Alegre (Figura 8.13) não se nota tanta predominância do papel e papelão, provavelmente porque a coleta seletiva é predominantemente portaa-porta, e portanto são coletados todos os materiais recicláveis acondicionados pela população, independente do valor de mercado, e porque há uma intensa atividade informal de catadores, que coletam predominantemente estes materiais (COSTA e SATTLER 1998).

Figura 8.12. Distribuição percentual dos materiais vendidos em programas de coleta seletiva em diversos municípios brasileiros (estudos de caso)

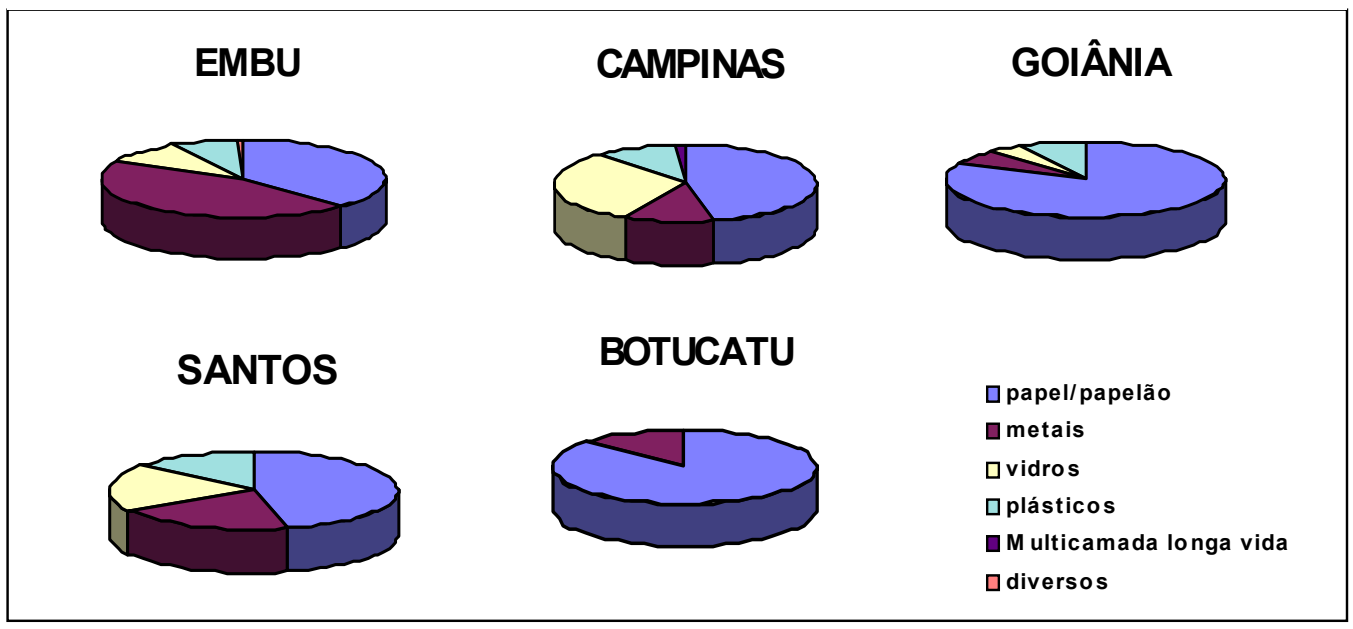


Figura 8.13. Distribuição percentual dos materiais vendidos em programas de coleta seletiva em municípios brasileiros (dados bibliográficos)

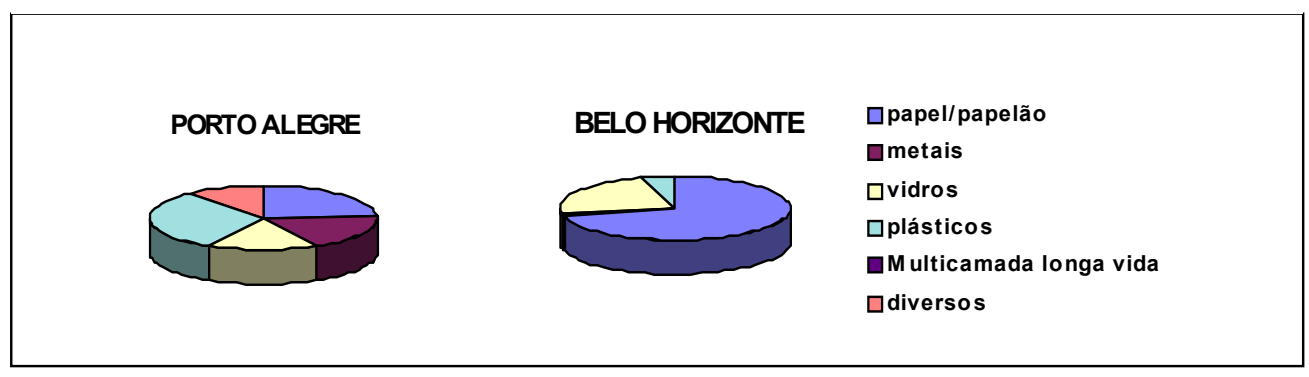

\subsubsection{Desvio de resíduos e recuperação de materiais}

Foram calculados, para cada município, a taxa de desvio e a taxa de recuperação. Para o cálculo das taxas de recuperação foi preciso estabelecer alguns critérios. Primeiro, a quantidade de resíduos de referência utilizada foi a quantidade gerada nas áreas atendidas pela coleta seletiva, estimada a partir do total de resíduos coletados institucionalmente e da população atendida. No caso de Botucatu, foi considerada como referência a quantidade de resíduos sólidos domésticos (escritórios, sanitários gerais e outros), gerada nos campi da UNESP. Não foram incluídas no cálculo das taxas os resíduos coletados informalmente, porque neste trabalho buscamos avaliar os programas institucionais.

A quantidade de materiais recuperados foi estimada considerando-se que os rejeitos são todos retirados na primeira operação de triagem do processo. Esta suposição é razoável porque os intermediários e indústrias que compram o material exigem um certo grau de limpeza para minimizar a necessidade de novas separações em suas instalações. Nos municípios de Botucatu e Belo Horizonte não havia dados disponíveis a respeito do índice de rejeitos no material depositado nos PEVs. Neste caso, foi considerado índice de rejeitos zero, já que a primeira triagem é realizada pelo próprio gerador. No caso de Botucatu, foi considerado apenas o papel, uma vez que não há controle quantitativo dos demais materiais. Isto introduz uma distorção na avaliação do programa, a qual não foi possível contornar dentro da metodologia proposta. 
Observa-se que dentre os estudos de caso, a maior taxa de desvio ocorre no município de Campinas, ou seja, este é o município que proporcionalmente coleta seletivamente, num programa institucionalizado, a maior fração percentual (Tabela 8.6).

Por outro lado em Goiânia observa-se a maior taxa de recuperação, o que significa um impacto ambiental maior em relação à área que o programa se propõe a atender. Este resultado é favorecido, entre outros fatores, pelo fato de a coleta seletiva ser realizada nos bairros onde moram os cooperados, provocando um contato bastante íntimo entre os coletores e a comunidade, e também pela coleta realizada no centro comercial da cidade.

Tabela 8.6. Taxas de desvio e de recuperação observadas nos estudos de caso.

\begin{tabular}{l|c|c}
\hline \multicolumn{1}{c|}{ Localidades } & Taxa de desvio & Taxa de recuperação \\
\hline Campinas & 2,39 & 1,77 \\
Goiânia $(*)$ & 0,11 & 7,82 \\
Embu & 2,17 & 3,91 \\
Santos & 1,82 & 1,67 \\
Botucatu $(* *)$ & 0,10 & 6,40 \\
\hline
\end{tabular}

(*) Não inclui resíduos gerados fora da área atendida. Incluídos estes resíduos a taxa fica em $16,3 \%$.

(**) somente papel; dos demais materiais não há controle de quantidade.

Os dois programas com melhores taxas de recuperação são aqueles cuja iniciativa é da sociedade, e não dos órgãos municipais. Isto mostra o potencial e a importância deste tipo de ação, no sentido da minimização de resíduos domésticos.

Como consideração geral, observa-se que as taxas de desvio em todos os estudos de caso são relativamente baixas. A média de materiais recicláveis presentes nos resíduos sólidos domésticos no Brasil, em várias cidades, é de 35\% (CEMPRE 1993). Segundo o WELLS e col. (1995) a média ponderada em diversas cidades brasileiras da taxa de desvio nos bairros onde havia coleta seletiva foi de 4,6 \%. Os resultados mostram que dois dos programas ora estudados obtiveram avanços, mas a 
maioria ainda permanece próxima abaixo da média nacional. Ainda há potencial para espaço para intensificar o trabalho de motivação da população e melhorar a quantidade de resíduos recicláveis coletada e recuperada.

É importante que, ao longo do processo de implantação da coleta seletiva seja feito um acompanhamento do impacto do programa, principalmente por meio da taxa de recuperação. Essa preferência se deve ao fato de que um incremento na quantidade coletada seletivamente, refletido na taxa de desvio, não leva necessariamente à recuperação de uma quantidade maior de material, podendo haver maior quantidade de rejeitos por motivos de defeitos de seleção ou saturação do mercado, entre outros.

$\mathrm{Na}$ Tabela 8.7 observa-se dados relativos a outras localidades, entre municípios e países. Devem ser observados à luz da limitação importante que é a falta de uniformidade dos critérios utilizados para os cálculos. Alguns incluem parcialmente resíduos industriais ou incluem resíduos de estabelecimentos comerciais de portes variados.

Tabela 8.7. Taxas de desvio e recuperação observadas em outras localidades

\begin{tabular}{l|c|c}
\hline \multicolumn{1}{c|}{ Localidades } & $\begin{array}{c}\text { Taxa de desvio } \\
(\mathbf{\%})\end{array}$ & $\begin{array}{c}\text { Taxa de recuperação } \\
\text { (\%) }\end{array}$ \\
\hline Belo Horizonte (1) & 1,11 & 1,29 \\
Porto Alegre (2) & 3,67 & 2,94 \\
Estados Unidos (3) & 28,0 & 54,9 \\
Suíça (4) & 30,8 & 41,4 \\
Alemanha (5) & 14,0 & 25,0 \\
\hline Calculado a partir de dados de: (1) MOTTA (1998); (2) PEREIRA e SANTOS \\
(1998); (3) GOLDSTEIN 1998; (4) FAHRNI e col. (1998); (5) \\
BUNDESUMWELTMINISTERIUM (1997) e DSD (1996).
\end{tabular}

Os cálculos mostram que, em relação aos municípios de Porto Alegre e Belo Horizonte, que têm programas muito bem conceituados nos meios técnicos, a taxa de recuperação de Embu é a melhor de todas, apesar de ter uma taxa de desvio mais baixa que a de Porto Alegre. Isto significa que o programa atua dentro de limites mais estreitos, mas onde ele atua, tem mais impacto ambiental do ponto de vista de 
materiais que deixam de ser aterrados. Os resultados de taxa de recuperação de Santos e Campinas estão abaixo de Porto Alegre, porém acima de Belo Horizonte. Isto pode ser devido ao fato de que em Belo Horizonte predomina o uso de PEVs, que exige mais mobilização popular para se coletar quantidades maiores de resíduos. Nota-se que os dois programas de iniciativa independente obtêm as melhores taxas de recuperação, devido à proximidade dos promotores dos programas com suas comunidades.

Nem a taxa de recuperação nem a taxa de desvio estão levando em conta quantidade de resíduos coletada informalmente por catadores, que em algumas cidades é muitas vezes superior à coletada pelos programas institucionais. É difícil medir a quantidade coletada informalmente nos municípios, mas apesar disso há algumas estimativas registradas. No município de São Paulo a inclusão do material coletado informalmente poderia adicionar uma quantidade da ordem de 2.500 toneladas diárias à quantidade de resíduos coletados pela prefeitura (RUBERG e col. 1998), o que significaria uma taxa de desvio da ordem de $20 \%$, significativamente maior que aquela calculada exclusivamente a partir da coleta municipal. Segundo COSTA e SATTLER (1998) há aproximadamente 1.140 catadores em Porto Alegre, que coletam aproximadamente três vezes mais material que o DMLU - Departamento Municipal de Limpeza Urbana. Considerada a mesma média de material coletado por catador em Porto Alegre, pode-se estimar que em Santos a coleta informal seja da ordem de $25 \mathrm{t} / \mathrm{dia}$, ou aproximadamente oito vezes mais que a coleta realizada pela PRODESAN.

Isto mostra que, ao implantar projetos de coleta seletiva e reciclagem, deve-se levar em consideração a atividade existente dos catadores, e tentar trazê-los como parceiros, buscando a melhoria de suas condições de trabalho e da eficiência de sua atividade, e não estabelecer com eles uma competição pelos materiais recicláveis. Este risco existiria, por exemplo, se fosse adotado um sistema de concessão para empresas particulares executarem a coleta e se apropriarem do material coletado. Neste caso seria necessário estudar alternativas como as parcerias entre a empresa 
concessionária e os catadores, ou a atuação da empresa somente nas áreas onde não há atuação de catadores.

É necessário portanto que se realizem pesquisas sobre a magnitude e a natureza da atividade de coleta informal antes de se iniciar a implantação de coleta seletiva institucionalizada.

\subsubsection{Vetores transmissores de doenças}

A infestação visualmente mais grave encontrada foi em Goiânia, onde há excesso de moscas na compostagem. Considerada normal pelos operadores, necessita de ações corretivas urgentes. Aparentemente, o material em processo não está atingindo temperaturas suficientes para eliminação das larvas, ao mesmo tempo em que a drenagem deficiente permite o acúmulo de líquidos nas canaletas e o desenvolvimento das larvas. Na visita prévia realizada foram localizadas também prováveis larvas de mosquitos nos tanques de água do processo de plástico. $\mathrm{O}$ esvaziamento dos tanques de água nas paradas para manutenção passou a ser realizado, após orientação dos cooperados, eliminando larvas de mosquitos.

Os problemas de infestação encontrados em Goiânia deveriam ter sido previstos nas etapas de planejamento, e certamente o acompanhamento técnico não foi suficiente ou não deu a atenção necessária de forma a eliminá-los nas etapas iniciais da implantação. O fato de o Núcleo Industrial de Reciclagem localizar-se num dos bairros atendidos é um agravante que teria que ter sido levado em conta. As medidas para eliminação de larvas de mosquitos nos tanques de água passaram a ser realizadas, porém para eliminação das moscas são necessários ajustes tecnológicos nas instalações de compostagem, podendo ser necessário o re-dimensionamento de equipamentos.

Em 50\% das instituições entrevistadas que manipulam fisicamente resíduos existem ações preventivas para evitar a proliferação de vetores, sendo a mais freqüente a aplicação periódica de venenos. Nas demais instituições, ações de 
combate químico nos locais de armazenamento, triagem e processamento são tomadas apenas quando da ocorrência de proliferação intensa ou quando os estabelecimentos são multados pelos órgãos de Saúde. As medidas preventivas relacionadas ao projeto e construção das instalações são praticamente inexistentes. A organização dos materiais e higiene às vezes mereceria também mais atenção.

Nas entrevistas foram feitas algumas referências às visitas dos órgãos de fiscalização sanitária. Muitas vezes as exigências dos órgãos de saúde são vistas como obstáculos, embora alguns dos entrevistados tivessem reconhecido a necessidade das ações exigidas. Em Campinas há uma fiscalização mais intensa por parte da Secretaria Municipal de Saúde devido à epidemia de dengue, principalmente nos sucateiros e na instalação das novas usinas de triagem descentralizadas.

O fato de terem sido identificadas infestações de artrópodes e roedores em três locais dos quatorze visitados onde havia manipulação de resíduos mostra que são necessárias medidas preventivas, especialmente a orientação quanto à execução sanitariamente correta das construções e do manuseio correto dos resíduos manipulados e dos materiais armazenados. A instituição que promove a coleta seletiva e reciclagem deve portanto efetuar um trabalho educativo neste sentido ou buscar um parceiro que o faça, que poderia ser um órgão da área da Vigilância Sanitária municipal ou estadual.

\subsubsection{Impacto social, educativo e participação da comunidade}

A participação mais significativa da população medida em termos da quantidade diária de resíduo coletada por habitante está em Campinas e em Goiânia. (Tabela 8.8). Um conjunto de fatores, como escolha das áreas com melhor potencial de coleta de resíduos recicláveis e as atividades de Educação Ambiental viabilizada por meio das parcerias com empresas favorecem a coleta em Campinas. Esta situação se refletiu em 1998 em problemas, já que não houve suficientes canais de escoamento do material, tendo havido a necessidade de enviar parte dos resíduos ao aterro sanitário, segundo os responsáveis. Em Goiânia a íntima relação entre a 
comunidade atendida pela coleta seletiva e a cooperativa gera uma adesão muito significativa da população.

Tabela 8.8. Coleta regular e seletiva de resíduos domésticos per capita

\begin{tabular}{ll|c|c}
\hline \multicolumn{1}{c|}{ Localidade } & $\begin{array}{c}\text { Coleta } \\
\text { regular } \\
\text { kg / hab. dia }\end{array}$ & $\begin{array}{c}\text { Coleta } \\
\text { Seletiva } \\
\text { kg / hab. dia }\end{array}$ \\
\hline Estudos de caso & Embu & 0,65 & 0,032 \\
& Campinas & 0,81 & 0,041 \\
& Santos & 1,02 & 0,021 \\
& Goiânia & 0,98 & 0,040 \\
& Botucatu & 0,80 & $\mathrm{ND}$ \\
\hline Referências & Belo Horizonte (a) & 0,53 & $\mathrm{ND}$ \\
bibliográficas & Porto Alegre (b) & 0,72 & 0,027 \\
\hline
\end{tabular}

(a) calculado com dados de MOTTA (1998)

(b) calculado com dados de PEREIRA e SANTOS (1998)

Estes números podem servir de base para instituições que desejam implementar programas de coleta seletiva e reciclagem em novas áreas, para estimar a adesão após uma etapa inicial. Poder-se-ia esperar, que programas mais antigos como os de Santos e Porto Alegre tivessem atualmente uma adesão mais significativa. Apesar dos esforços já empreendidos, há a necessidade de maior investimento em Educação Ambiental para melhorar a adesão da população nos municípios citados.

Em Campinas o DLU tem tido dificuldade de atender a pedidos de comunidades organizadas, como escolas, que desejam fazer a coleta seletiva. Em Santos já está em trâmite documento legal para tornar obrigatória a segregação de resíduos na fonte em condomínios, o que deve aumentar a adesão da população. Por outro lado, em Embu nota-se que em algumas escolas há uma participação dos alunos caracterizada pela coleta de materiais diversificados em tambores. Em outras, apenas era coletado o papelão proveniente das embalagens da cozinha, caracterizando uma participação menos significativa das crianças, havendo neste sentido oportunidade para melhorias.

Em Embu, nota-se que alguns moradores se mobilizam de forma particularmente intensa. Adultos e crianças por vezes aguardam a chegada do caminhão, anunciada pelo sino, e entregam pessoalmente o material separado para os 
coletores. Este particular não foi observado no curto período em que foram acompanhada a coleta em Campinas e em Santos. Em Goiânia os cooperados são moradores dos bairros atendidos, e o Projeto meia Ponte como um todo tem modificado bastante a rotina e a vida das pessoas. A coleta seletiva tem obtido adesão mesmo de pessoas que no início ofereciam bastante resistência.

$\mathrm{O}$ contato entre o catador ou coletor e a população mostra-se portanto essencial. A habilidade desses trabalhadores em conquistar a simpatia da população atendida e com ela estabelecer laços de confiança pode ser um instrumento extremamente forte para obter a adesão da população. Isto foi observado em Embu. Em Goiânia também, havendo inclusive treinamento específico para que cooperados possam executar atividades de educação ambiental e de captação de material em instituições potencialmente doadoras. Estes novos papéis são habilidades pessoais a serem desenvolvidas nos trabalhadores que travam contato com a população.

Salta aos olhos que quase todos os programas são associados a ações de melhoria de qualidade de vida de grupos de indivíduos como catadores (Embu), carrinheiros (Santos), pacientes de serviços de saúde mental (Santos e Campinas), presidiários (Campinas) e população de bairro de baixa renda (Goiânia). Este fato propicia, por um lado, possibilidades enormes de parcerias e de redução de custos operacionais dos projetos, entretanto leva à necessidade de pessoal especializado para tratar com estes grupos.

A geração de emprego e renda para estes grupos traz os benefícios do resgate da cidadania e da auto-estima. Os rendimentos individuais, entretanto, são geralmente baixos, situados entre um e dois salários mínimos. A automação de certas atividades e a aplicação de conhecimentos de administração industrial poderia melhorar a produtividade do trabalho deste pessoal, desde que acompanhada com um intenso trabalho de desenvolvimento pessoal. 
As atividades de Educação Ambiental abrem possibilidades imensas para parcerias. Destaque-se nos programas estudados as parcerias da Prefeitura Municipal de Campinas com a Tetra Pak, que cedeu material impresso de divulgação.

\subsection{Situação em relação às recomendações de trabalhos anteriores}

\subsubsection{Agenda 21}

Nenhum dos municípios estudados têm Agenda 21 Local aprovada, embora alguns deles estejam desenvolvendo suas Agendas. O Brasil também ainda não tem sua própria Agenda 21 aprovada. Analisa-se nesta seção se os programas cumprem os itens pertinentes da Agenda 21 Global. Não se pretende aqui esgotar a análise, mas sim chamar a atenção para alguns pontos concernentes ao objeto deste trabalho.

O estímulo à reciclagem faz parte de todos os programas estudados, sendo sempre um dos seus principais componentes. Falta, em alguns casos, uma visão mais integrada do mercado e da necessidade de incorporação de conceitos modernos de administração industrial às atividades de reciclagem. Destaque-se aqui o apoio que vem sido obtido pela COOPREC de Goiânia para estabelecimento das especificações técnicas das telhas, o que contribuirá para a melhor aceitação do material no mercado.

A redução do desperdício de embalagens já não faz parte das principais diretrizes dos programas. O esforço que mais se aproxima é, num dos departamentos da UNESP, a eliminação do uso de copos descartáveis. Também não é apresentada de forma objetiva no material de comunicação apresentado. Os esforços de mobilização da população são praticamente todos direcionados para a adesão à coleta seletiva. Corre-se o risco, assim de gerar uma aprovação do desperdício, inclusive de embalagens, pela existência do programa de coleta seletiva e reciclagem. O programa USP Recicla (BLAUTH e LEME 1998) registra uma intenção que parece mais ambiciosa em termos de mudança de comportamento, e registra uma queda na produção de resíduos nas unidades da USP em que atua. 
O estímulo à introdução de novos produtos ambientalmente saudáveis restringe-se, em geral, à reciclagem de produtos. Destaque-se as iniciativas de Goiânia, com a instalação de uma usina que integra a reciclagem das fibras, do polietileno e da matéria orgânica e o desenvolvimento de novas tecnologias, como a reciclagem das embalagens longa vida viabilizada pela ação da Tetra Pak e seus parceiros e as pesquisas em reciclagem de plásticos realizadas pela UNESP. Também a iniciativa de um consórcio formado por diversas empresas associadas ao ITAL Instituto de Tecnologia de Embalagem de Alimentos para estudo de ciclo de vida de produtos com embalagens descartáveis mostra um início de avanço nesta área.

O mesmo capítulo recomenda ainda fortemente a utilização de políticas de preços e instrumentos econômicos para induzir a mudança de hábitos dos consumidores. Em nenhum dos municípios estudados existe tarifação do serviço de coleta de lixo que estimule a coleta seletiva e reciclagem. Em nível Estadual e Nacional vêm sendo discutidas as respectivas Políticas de Resíduos Sólidos (SMA 1998b, 1998c). Nestes documentos estão incorporados o uso de incentivos econômicos e a possibilidade de responsabilização do fabricante pelo resíduo gerado por produtos especiais. Este último instrumento, que gera conseqüências sobre os preços dos produtos, deveria ser adotado em nível nacional, e não estadual, sob pena de gerar desigualdades regionais e possível migração de negócios de estados mais exigentes para outros menos exigentes.

O Capítulo 21 da Agenda 21 Global volta a recomendar a minimização de resíduos, a maximização ambientalmente saudável do reaproveitamento e da reciclagem, além da disposição e tratamento ambientalmente saudáveis e a ampliação do alcance dos serviços que se ocupam de resíduos.

Para a minimização de resíduos, são estabelecidos como objetivos a estabilização ou redução, num prazo que seja acordado, a produção de resíduos destinados à disposição final, e ao mesmo tempo é enfatizada a necessidade de monitoramento e da disponibilidade de dados para acompanhamento e tomada de 
decisão (CNUMAD 1992). No Brasil não há metas estabelecidas em nível nacional para tais reduções. Alguns programas municipais estabelecem metas redução, principalmente por meio da ampliação de coleta seletiva, entre outras alternativas. Ainda há dificuldades, no Brasil, quanto à disponibilidade de dados para tal gerenciamento. Iniciativas recentes como as do CEMPRE e do CIRS, que pesquisam dados de vários municípios e os divulgam, e mesmo o inventário de resíduos sólidos conduzido pela CETESB, ainda que mais orientado pela correta destinação final que pela minimização, têm trazido contribuições importantes. Falta a iniciativa governamental de criar um sistema nacional de informações de resíduos sólidos, que padronize e sistematize os dados e facilite sua disponibilidade.

Para a maximização de resíduos, a Agenda estabelece o prazo do ano 2.000 nos países desenvolvidos e 2.010 nos países em desenvolvimento para o estabelecimento de programas nacionais que incluam, na medida do possível, metas para reutilização e reciclagem. as experiências municipais e autônomas que vêm ocorrendo devem desempenhar um papel fundamental, como lições já aprendidas, na construção do Programa Brasileiro de Reciclagem, instituído pelo Ministério da Indústria, do Comércio e do Turismo (MICT 1998) Isto ainda abre mais uma possibilidade importante de parcerias, entre o Ministério e municípios ou organizações que queiram fazer reciclagem, para aprimoramento de programasmodelo e desenvolvimento de novas tecnologias para multiplicação em diversos locais, inclusive com o intercâmbio de profissionais experientes.

A assistência técnica às atividades informais de reutilização e reciclagem de resíduos vem sendo feita ainda com discrição. Em Embu o programa se originou do apoio aos catadores. Em Goiânia a prefeitura dá apoio discreto à atividade já formalizada da cooperativa. Em Botucatu a UNESP não tem apoio mais que formal do governo municipal para sua coleta seletiva interna, e a municipalidade rejeitou a proposta para execução de coleta seletiva em nível municipal. Em Santos o apoio aso carrinheiros vem sendo diminuído após a mudança do governo municipal, especialmente o apoio à Associação e o Programa dos Trabalhadores Ecológicos. Essa integração com a atividade informal existente poderia oferecer oportunidades 
excelentes para organização da coleta seletiva municipal, facilitando a participação da comunidade, melhorando as condições de trabalho daqueles já envolvidos, e facilitando a comercialização dos resíduos domésticos por tirar proveito da rede comercial já existente e da economia de escala de que dispõe a reciclagem de resíduos industriais e comerciais. Por enquanto vem sendo bem aproveitadas num número reduzido de municípios.

As condições jurídicas que conduzam ao investimento para reutilização e reciclagem em geral existem. A legislação do município de Campinas que incentiva a existência de iniciativas não municipais e o projeto de lei de Santos para a obrigatoriedade da coleta seletiva nos condomínios são bons exemplos de incentivo nos programas estudados. A legislação de concessão ou contratação dos serviços municipais de resíduos sólidos precisaria ser melhor estudada, para não criar conflitos como o existente em Goiânia. Também a legislação sobre venda e cessão de materiais recicláveis pelas prefeituras precisa ser melhor fixada, a fim de facilitar a comercialização pelas prefeituras, sem prejuízo da correta cobrança dos valores.

Por outro lado, as condições econômicas nem sempre são favoráveis. O uso de matérias-primas virgens ainda é em muitos casos mais barato que o uso de materiais reciclados. Isto ainda é resultado das distorções de mercado advindas da ausência da internalização de certos custos ambientais, como áreas para aterro, controle ambiental, água, energia e exaustão de recursos naturais.

A coleta em separado das partes recicláveis dos resíduos domésticos é uma recomendação atendida por todos os programas estudados, dentro das áreas atendidas. Falta ainda ampliar o atendimento e a adesão da população nas áreas atendidas.

Dos cinco programas estudados, os dois de iniciativa não-municipal preocupam-se especialmente com a colocação no mercado de produtos reciclados (UNESP e Goiânia), enquanto os outros três (Campinas, Embu e Santos), de iniciativa das prefeituras, não têm preocupações específicas a este respeito, 
limitando-se a se ocupar da venda dos materiais recicláveis, dentro das limitações já estabelecidas pelo mercado atual. Esta deveria ser uma preocupação das prefeituras a ser incluída em suas políticas com relação às indústrias e em suas atividades em Educação Ambiental. Nenhum dos projetos estudados participa de programas governamentais específicos para este incentivo.

Em todo o documento existe a ênfase no desenvolvimento de recursos humanos, tanto no que se refere ao treinamento de técnicos quanto ao envolvimento de organizações não governamentais. $\mathrm{Na}$ maioria das experiências estudadas as deficiências de formação e a falta da eficácia de atuação de técnicos das entidades promotoras estavam presentes. Estas falhas levaram, entre outros, a problemas administrativos e de execução de atividades de educação e envolvimento da comunidade. Entre as causas identificadas estavam a falta de formação específica, a falta de envolvimento dos colaboradores e a insuficiência de pessoal, em um número menor de casos. No caso das cooperativas uma das dificuldades mais importantes relatadas foi o desenvolvimento de um "espírito empresarial" nos cooperados, principalmente pelo contraste entre os papéis de patrão e empregado, e pela dificuldade de adaptação dos cooperados ao novo papel. Este ponto parece crucial, e deve haver o desenvolvimento de profissionais capazes de executar este tipo de intervenção.

Em nenhum dos programas estudados há ações voltadas à solução de tratamento ou disposição final de resíduos sólidos perigosos de origem doméstica, como pilhas e baterias, embalagens vazias de tintas, inseticidas, solventes e outros produtos, lâmpadas contendo mercúrio e outros. Faz-se necessário iniciar ações neste sentido, aproveitando a mobilização obtida nos programas de coleta seletiva.

\subsection{2. "Lixo Municipal - Manual de Gerenciamento integrado"}

Em alguns casos não há esquema na região para escoamento de materiais, como Vidro em Botucatu e certos plásticos em Goiânia, fato que deveria ter sido verificado antes do início da coleta. 
A venda de materiais recicláveis para várias empresas, para estimular a competitividade, praticamente não existe. Cada material costuma ser vendido sempre para o mesmo intermediário ou indústria, seja por comodidade, por parceria ou pela formação de cartel dos maiores sucateiros.

O Planejamento de estoques para enfrentar a sazonalidade dos preços praticamente não existe. Quando há dificuldade em vender um material, ele é estocado até esgotar a capacidade do depósito, em seguida é vendido. As centrais de triagem não são projetadas para armazenar estoque suficiente para aguardar crises.

A implementação da coleta seletiva pela prefeitura é objeto de três dos programas estudados, embora outras etapas da reciclagem não sejam incentivadas pelas prefeituras. As prefeituras de Embu, Santos e Campinas incentivam a coleta nas comunidades. Nas proximidades há mercado para a reciclagem, mas em nenhum caso foi identificado incentivo à instalação de indústrias no município. A prefeitura de Goiânia A prefeitura de Botucatu tem ações que ainda estão no papel. Em Goiânia, as ações são incipientes.

Não se observou em nenhum dos órgãos municipais visitados especial preocupação com o consumo de produtos reciclados. É preciso estudar como fica, do ponto de vista da Lei das Licitações, a exigência a fornecedores de que o papel ou outro produto qualquer seja reciclado. A realidade do mercado mostra que este consumo é, na maioria dos casos, economicamente viável somente em pequena escala.

A maioria dos programas faz controle do material vendido, mas há relativamente pouco controle do material coletado. Esta dificuldade se origina na falta de balanças rodoviárias em locais estratégicos para pesagem dos caminhões, principalmente em Embu, Botucatu e Campinas. O índice de rejeitos também é pouco controlado. 
No tocante às ações para o programa de reciclagem, em todos os casos foi relatado algum tipo de planejamento. Mas em Embu, Santos e Goiânia não existem dados facilmente acessíveis sobre a caracterização dos resíduos gerados, o que prejudica o planejamento e a identificação prévia de dificuldades, mas não necessariamente impede a implementação da coleta seletiva e reciclagem, já que a existência de catadores indica que o potencial existe. Como conseqüência também fica prejudicada a estimativa dos custos. Os contatos com sucateiros e fabricantes necessariamente existe, mas não ficou claro como foram feitos estes contatos nas etapas preparatórias da implantação dos programas. Em Embu alguns dos intermediários que já compravam material dos catadores continuaram comprando, porém com melhor preço.

Em Embu e em Goiânia, onde há a formação de cooperativas, as instituições promotoras auxiliam na gestão técnica e administrativa, o que é importante de acordo com a publicação. Também há, na maioria dos programas, acompanhamento do retorno dos benefícios à comunidade.

Como forma de reduzir os custos da coleta seletiva, a publicação recomenda aprimorar a divulgação. Há uma preocupação em geral com este componente, embora após um impulso inicial ele receba menos atenção. $O$ único caso estudado em que a divulgação é realmente deficiente foi Botucatu. Em Embu há uma necessidade importante de retomar campanhas mais agressivas, principalmente nas escolas.

Somente o programa de Embu organiza catadores, entre os programas estudados. O programa de Santos já incluiu esta atividade, atualmente praticamente desativada.

Nos municípios de Goiânia e Campinas foram identificadas iniciativas espontâneas incentivadas pelas prefeituras, com maior ou menor sucesso. Em Botucatu o programa é absolutamente independente do poder municipal, e em Goiânia o apoio municipal está abaixo do desejável. 
Nos programas de Embu, Goiânia e Botucatu naturalmente ocorre o interesse maior pelos materiais que representam a maior receita. Nos programas em que a prefeitura executa ou contrata por peso a coleta, não há esta preocupação.

As tecnologias utilizadas nos programas são aquelas acessíveis, e necessariamente adaptadas à realidade local. No caso de Goiânia as dificuldades encontradas para a aplicação das tecnologias previstas foram administrativas, e no caso de Embu há melhorias previstas. 


\section{AS PARCERIAS E A VIABILIZAÇÃO DOS PROGRAMAS DE COLETA SELETIVA}

Para que se possa implantar um programa de coleta seletiva e reciclagem de resíduos sólidos domésticos são necessários canais comerciais, recursos humanos e recursos técnicos materiais. Conforme identificado nos casos estudados, os recursos podem ser provenientes de instituições diversas, o que exige ainda que a estrutura do programa tenha capacidade de articulação inter-institucional e a disponibilização de recursos financeiros.

\subsection{Requisitos para implantação de programas de coleta seletiva}

Cada um dos requisitos pode ser satisfeito por meio de parcerias e apoios diversos. Há alguns tipos de apoio importantes que não necessariamente são parcerias no sentido da colaboração bilateral, porque com muita freqüência quem apóia não tem nenhuma fraqueza a ser minimizada. Mesmo assim esses apoios contribuem decisivamente para o fortalecimento dos programas, e por isso são também chamados frequentemente de parcerias.

\section{a) Recursos técnicos materiais}

Entre as formas mais importantes de viabilizar recursos técnicos e materiais estão as parcerias de cessão e de comodato de equipamentos. Em Campinas há prensas cedidas ao DLU por empresas compradoras. Em Goiânia, o contrato de comodato dos equipamentos entre a SGC e a COOPREC uma das bases importantes da parceria. Em Santos, os veículos da coleta seletiva são utilizados pela TERRACOM em comodato, sendo a PRODESAN a proprietária dos veículos. Situação parecida ocorre em Embu, onde a Prefeitura cede veículos e motorista, e a COOPERMAPE efetua a coleta. 


\section{b) Recursos humanos}

Parcerias na área de Educação Ambiental podem proporcionar a obtenção de material didático e/ou pessoal capacitado. Exemplos importantes são a doação de material gráfico por empresas, que ganham com isso uma melhor imagem junto à população. As empresas geralmente não oferecem mão-de-obra de profissionais capacitados, sendo estes contratados normalmente pela entidade promotora do projeto (isto foi observado em Embu, Campinas, Botucatu e Goiânia). Os profissionais necessários ao programa podem ser contratados com recursos obtidos externamente ou por meio de parcerias com órgãos municipais, como as Secretarias de Educação, ou por meio do treinamento de membros de entidades multiplicadoras como igrejas e associações de bairros.

No âmbito local, é preciso que empresas se voltem para esta atividade e que portanto o poder público as incentive, não apenas com incentivos fiscais, mas também com a preparação dos empresários para atuar na área. Num nível nacional, é preciso que haja políticas que incentivem os empresários a desenvolver produtos reciclados, ao mesmo tempo que deve haver canais para desenvolvimento e transferência de tecnologia. A inclusão desta componente no projeto de Goiânia é um exemplo claro disto, e o projeto de Botucatu é o outro exemplo importante. Nesse ramo há um interesse especial pela reciclagem do plástico, que pode ser feita por empresas de pequeno porte. Mas não se pode esquecer da reciclagem dos outros materiais, que exigem investimentos em maior escala.

Quanto à ação de ONGs de suporte, FISCHER (1993) ressalta a importante diferença entre os beneficiários terem voz nos projetos iniciados por agentes externos, ou passarem por processo de desenvolvimento autodirigido apoiado por agentes externos. Esta diferença é importante, e a instituição promotora precisa ter bem clara qual é a sua intenção de projeto. A tendência entre os profissionais que trabalham com o conceito de desenvolvimento sustentável trabalham com os catadores na segunda alternativa, mas ainda há instituições com conceitos arraigados 
que buscam atuar no primeiro modelo. Em certa medida o mesmo vale para intervenções governamentais.

No caso de serem incentivadas as cooperativas, seus integrantes geralmente são originários das camadas mais simples da população, e não estão acostumados a ser seus próprios patrões ou empresários. Esta mudança de postura precisa ser trabalhada, identificando nos grupos as lideranças positivas capazes de catalisar este processo, tomando o cuidado para que elas não transformem a cooperativa em uma empresa particular. Este processo é lento e é um dos pontos mais difíceis, mas é essencial se é almejada a independência da cooperativa, de forma que este investimento em recursos humanos torna-se essencial. Os exemplos de Embu e Goiânia mostram isto, que contratam profissionais com perfil para atuar neste sentido. O apoio do SEBRAE também tem sido significativo.

Além disso podem ser necessários trabalhos nos campos do desenvolvimento pessoal (alfabetização, tratamento de alcoolismo e dependência de drogas, etc.), técnico (reconhecimento de materiais, separação, armazenamento), administrativo (conhecimentos de informática e contabilidade) e outros. Em Embu e Goiânia há exemplos deste tipo, por meio de apoio de diversas entidades.

O treinamento do pessoal operacional quanto aos conhecimentos técnicos envolvidos nas atividades também é um campo fértil para parcerias. Um exemplo de parceria de transferência de tecnologia é o caso do treinamento dos cooperados de Embu para triagem do papel vendido à RIPASA. Este treinamento garante à empresa a qualidade do material comprado. Uma indústria recicladora de PET faz este trabalho no estabelecimento de parcerias com prefeituras e sucateiros de quem compra o material. (AGUIAR e PHILIPPI Jr. 1998). A obtenção de material com qualidade é uma das chaves, nestes casos, para manter os custos industriais mais baixos.

A capacidade de articulação inter-institucional, necessária para a formação das parcerias, está associada intimamente à formação e à experiência daqueles que 
trabalham nas instituições que tomam a iniciativa dos programas, embora deva estar presente também em outras instituições. No caso das administrações municipais, este é um dos enfoques importantes. Os profissionais envolvidos têm que ter fundamentalmente esta capacidade.

A capacidade de articular as instituições está também intimamente ligada à capacidade de gerar as necessárias pressões políticas para que os programas de coleta seletiva e reciclagem sejam priorizados politicamente. Esta capacitação também integra o rol de habilidades necessárias aos profissionais e à população envolvida.

\section{c) Canais de mercado}

Vários aspectos estão envolvidos neste elemento. O desenvolvimento e a transferência de tecnologias de reciclagem, ou seja, da produção de produtos com valor de mercado a partir de materiais recicláveis, é essencial. As associações de empresários dos setores envolvidos poderiam tomar esta iniciativa, em especial tem havido atuação discreta das associações de indústrias empresas de reciclagem e de sucateiros no sentido de se desenvolver incentivos econômicos e fiscais para a atividade para fins de viabilização econômica. A atuação das associações mostra-se importante porque seria muito difícil as empresas recicladoras e sucateiros, isoladamente, conseguir vencer as pressões dos gigantes fabricantes de matériasprimas virgens como as petroquímicas, as indústrias de celulose e as mineradoras.

Por outro lado, as parcerias de natureza comercial entre fornecedores e cliente, que envolvem basicamente a garantia do preço mediante especificações técnicas de quantidade e qualidade, também podem facilitar o escoamento. Neste caso específico é difícil definir o limite entre a parceria e a relação comercial simples. Esses acordos geralmente estão apoiados concomitantemente em parcerias operacionais, como a disponibilização de caçambas e contêineres. 


\section{d) Recursos financeiros}

Instituições dispostas a investir, mas que não detêm o conhecimento ou não têm pessoal para fazê-lo transferem recursos para instituições que têm projetos específicos e competência para implementá-los. É o caso do financiamento federal oferecido ao projeto de Goiânia e do apoio do UNIBANCO Ecologia ao projeto de Botucatu.

O apoio governamental via subsídios e renúncia fiscal voltados para implementação dos primeiros passos seria uma forma interessante de incentivar a instalação de novas indústrias. Em nenhum dos casos foi identificado este tipo de ação governamental.

No caso de formação de cooperativas, costuma haver subsídios como oferecimento de cestas básicas e ajudas de custo nas etapas iniciais do projeto. Isto foi observado em Goiânia e em Embu.

\subsection{A atuação dos diferentes setores}

Ao observar as características das parcerias centrais dos programas, constatase que se formam parcerias entre setores da sociedade.

Entre as parcerias público-privado, destacam-se a parceria entre a Prefeitura de Embu e os catadores e a antiga parceria entre a Prefeitura de Santos e os catadores, ora desativada. A coleta via catadores melhora a chance de comercialização e retira da prefeitura parte da carga operacional. Havendo acordo de programação de coleta, como em Embu e Goiânia, caracteriza-se como um regime de contracting out. É também o caso da contratação de empreiteiras, como na coleta atual porta-a-porta em Santos. Neste caso, em particular, não ficou evidente vantagem substancial para a Prefeitura Municipal em contratar uma empresa privada para executar a coleta, com os próprios caminhões municipais em comodato, dado 
que a diferença entre o custo próprio e o contratado relativamente pequena. A existência de intenso mercado informal e de inúmeros catadores não participantes da Associação dos Carrinheiros indica que há ainda espaço para a atuação e parcerias no sentido da evolução para um modelo mais eficiente e barato.

Nas parcerias público-privado, caberia ainda ao setor público, a motivação da população. Porém a maior adesão dos moradores é também interesse do empreiteiro ou contratado, que receberá por quantidade coletada - no caso de contratação do serviço de coleta - e que também receberá mais por vender mais material, desde que o mercado não esteja saturado.

A atribuição da triagem dos materiais recicláveis a agentes privados é uma tendência clara. Os gestores dos programas parecem já ter compreendido que esta é uma atividade agregadora de valor ao material como mercadoria, e portanto uma atividade econômica lucrativa e que interessa a catadores e cooperativas, sucateiros e industriais. Os programas que tem custos mais baixos fazem esta atribuição, embora os custos de capital de investimento para instalação de cooperativas ainda sejam arcados pelo poder público.

Conclui-se que em nenhum dos casos de iniciativa da Prefeitura Municipal foi delegada a gestão ao setor privado, mas sim a execução de serviços mediante acordos específicos. Delegar a gestão significaria ter que desenvolver novos instrumentos reguladores, que a exemplo de outros setores ligados a serviços públicos essenciais, teriam que alinhar os interesses puramente privados aos interesses da sociedade como um todo.

As parcerias privado-privado consistem algumas vezes consistem em parcerias de natureza comercial, em que ficam garantidas a quem compra os materiais recicláveis o fornecimento exclusivo e com qualidade, mediante a garantia da compra e do preço. Foram observados exemplos de parcerias para desenvolvimento de tecnologia a destacar é a relação entre a Tetra Pak e a Biagioni aparas, que processa resíduos das embalagens longa vida. Por fim, há o caso de 
Goiânia, em que a uma ONG (a SGC) substitui o Estado como promotor do projeto, fazendo a parceria com a comunidade local. Esta substituição do Estado pela organização privada é o caso também dos condomínios que têm coleta seletiva própria e destinam o material a entidades filantrópicas ou catadores atuantes na região. Este é um tipo de ação que deveria ser incentivada junto a condomínios já existentes, especialmente nos grandes centros urbanos, porque aí há condições claras de economia de escala.

No caso de Botucatu, em que a UNESP, apesar de ser autarquia pública, não tem a responsabilidade sobre a gestão dos resíduos municipais, e que a Prefeitura não participa do programa, este assume dimensões de iniciativa independente, quase como se fosse privada.

Dentre os casos estudados, há duas parcerias centrais do tipo público-público: em Campinas em Santos, nos dois casos envolvendo dois órgãos do mesmo município.

Um tipo de parceria que parece importante, principalmente para pequenos municípios, que a teoria reconhece como importante é a parceria entre diferentes municípios. Elas sempre se apresentam como propostas promissoras do ponto de vista econômico, ambiental e operacional para problemas de resíduos sólidos, entretanto do ponto de vista político não se sustentam pela falta de continuidade dos projetos quando da mudança de governos após as eleições. Nos programas estudados, o único caso que se aproxima disto é o município de Santos, que recebe em sua central de triagem os resíduos provenientes da coleta seletiva de São Vicente.

Nesta categoria poderiam também ser classificadas as parcerias entre diferentes esferas governamentais. A única parceria deste tipo notada foi a obtenção de recursos do Estado de São Paulo para o Município de Embu implantar a coleta seletiva e executar Educação Ambiental, recursos estes originários do Programa de Recuperação da Bacia do Guarapiranga. GOLDSTEIN e GLENN (1997) relatam que 
Estados dos EUA gastaram em 1996 mais de 180 milhões de dólares patrocinando programas municipais de reciclagem.

Em qualquer cooperação público-privado cabe ao poder público a capacidade organizacional e de promoção das atividades, para definição de objetivos e do controle da sua obtenção. (BERNAREGGI 1992). No caso do gerenciamento de resíduos sólidos domésticos, este papel cabe principalmente o município, mas a efetivação da reciclagem e de outras soluções pode passar por acordos regionais e pela necessidade de investimentos mais pesados, passando aí a envolver também Estados e a União. A clara relação da coleta seletiva e reciclagem de resíduos com aspectos sanitários, ambientais, sociais, econômicos e tecnológicos tem como conseqüência também o envolvimento dos Estados e União porque eles dão diretrizes em suas Políticas: Econômica, Industrial, de Ciência e Tecnologia, Ambiental e Social que podem favorecer ou dificultar a implantação de coleta seletiva e reciclagem ou de qualquer outra solução para o gerenciamento integrado de resíduos sólidos domésticos. O Setor público não precisa, no mercado de recicláveis, concorrer com o setor privado, e sim buscar nele os parceiros necessários para atingir seus objetivos.

Por outro lado, OJEDA (1998) trabalha com três modelos de gestão: Municipal, misto e privado. Afirma que qualquer que seja o modelo de gestão adotado, a capacidade para comunicação com o púbico e promoção e a responsabilidade associada a definição de tarifas e a capacidade de vigilância e controle são, como capacidades, requisitos para qualquer programa de gerenciamento de resíduos sólidos.

Com o menor envolvimento do município com determinadas partes do sistema, as capacidades de administração de pessoal e operação e manutenção são prescindíveis, enquanto preparação e negociação de contratos e supervisão de operações devem ser incrementadas. 
O autor não associa, entretanto, a capacidade municipal "comercialização reciclagem" aos modelos misto e privado, porque este conjunto de atividades estaria atribuído ao setor privado. $\mathrm{O}$ mercado da reciclagem faz parte do gerenciamento de resíduos, não pode ser considerado algo isolado dele, e por isso deve ser conhecido da administração municipal responsável por tal gerenciamento. É de interesse do município que a maior quantidade possível de material proveniente dos resíduos domésticos seja reciclada.

Portanto, é preciso que a administração municipal conheça bem o processo de comercialização e reciclagem de resíduos, para que saiba reconhecer as ações ao seu alcance no sentido de viabilizar a instalação de usinas de triagem e de unidades industriais, inclusive as de propriedade privada, e as ações que devem ser negociadas em âmbito regional, estadual ou nacional para viabilização da reciclagem do lixo. A administração municipal precisa ter profissionais com bons conhecimentos de comercialização de materiais recicláveis.

É claro que a participação maior das empresas privadas em parcerias nos programas estudados concentra-se na comercialização e no processamento industrial dos materiais recicláveis, consolidando a necessária produção de bens de consumo com tais materiais. Além disso, para viabilização do processo como um todo, pode-se destacar as atuações no sentido do oferecimento de equipamentos em comodato, do fornecimento de material educativo e do desenvolvimento e transferência de tecnologia.

Por outro lado, há espaço também para a participação privada na atividade de coleta. No exemplo de Santos, em que a empresa TERRACOM executa a coleta seletiva e recebe por tonelada coletada, exatamente como na coleta regular mas recebendo por ela praticamente o mesmo valor que a PRODESAN gastava executando ela mesma o serviço. É uma atividade de poucos riscos, e se a qualidade da separação for ruim e a população misturar na coleta seletiva materiais não recicláveis, a própria população estará pagando e a empresa estará se beneficiando. Seria interessante poder atingir uma situação em que as empresas privadas 
assumissem também os riscos inerentes ao mercado de recicláveis. Seria o caso, por exemplo, de a Prefeitura pagar a elas o mesmo preço que paga pela coleta regular, com o benefício para a empresa de ficar com a propriedade do material coletado, como propõe CALDERONI (1998). É mais ou menos o que ocorre em Goiânia com a COOPREC. Neste caso, ao mesmo tempo em que a empresa se interessará pelo aumento da quantidade, poderá se interessar também pela melhoria da separação. Poderia inclusive ser levada a executar também investimentos em Educação Ambiental. A empresa passa a assumir também algumas atividades de gestão. Mas para que isto se desenvolva é preciso que haja políticas públicas transparentes e mecanismos de controle que garantam a satisfação do interesse coletivo.

Por fim, no presente estudo, são identificadas algumas ONGs com atuação significativa. O IDF - no Projeto Meia Ponte, trabalha basicamente como "organização de suporte", induzindo e promovendo a organização de uma comunidade para a formação da cooperativa, com quem estabelece uma parceria. Conforme afirma FISCHER (1993), os grupos mais capazes inicialmente organizados por agentes externos devem, por definição, ter se tornado mais autônomos.

Os casos estudados revelaram que em algumas experiências o poder público tem se afastado ou mesmo se omitido, dificultando a ampliação dos programas. Em alguns casos têm tomado a iniciativa de executar projetos, às vezes substituindo a ação estatal num primeiro momento, buscando depois as parcerias necessárias e o apoio dos órgãos públicos, confirmando esta possibilidade de ação. Nesta linha foi constatada a atuação na capacitação de cooperados e na formação de cooperativas. Nos programas de coleta seletiva, ONGs de suporte têm tido importante papel na promoção de programas, como é o caso do Projeto Meia Ponte em Goiânia.

A atuação do terceiro setor na Educação Ambiental também foi constatada em alguns dos programas estudados, o que deve contribuir aos poucos para que haja mais pressão da população para se implementarem políticas públicas de resíduos sólidos. Seria interessante que o trabalho das ONGs fosse mais apoiado e 
intensificado. Os níveis de governo estadual e municipal não podem impor soluções para os resíduos sólidos domésticos em suas políticas, já que o gerenciamento desses resíduos é de competência municipal. Por isso poderiam apoiar as atividades das ONGs em Educação Ambiental, de modo a criar mais pressão para que os órgãos municipais busquem apoiar e promover programas de minimização de resíduos em geral, e de coleta seletiva e reciclagem em particular. 


\section{REFERÊNCIAS BIBLIOGRÁFICAS}

1. [ABNT] Associação Brasileira de Normas Técnicas. NBR 10.004 resíduos sólidos classificação. S.1.; 1987.

2. Acurio G, Rossin A, Teixeira, PF, Zepeda F. Diagnóstico de la situación del manejo de residuos sólidos municipales en América Latina y el Caribe. Washington (DC): OPAS/BID; 1997.

3. Aguiar A, Philippi Jr. A. Reciclagem de plásticos de resíduos domésticos: problemas e soluções. In: Anais do XXVI Congresso Interamericano de Engenharia Sanitária e Ambiental; 1993 nov 1-5; Lima, Peru [CD ROM]. Lima: AIDIS; 1998.

4. [Anônimo] Cotações atuais e passadas. In: Planeta dinheiro [banco de dados online]. Disponível em <http://pladin.uol.com.br/pladin/scripts/historic.asp> [1999 jul 8].

5. Alboreda S. Armazenamento dos materiais recicláveis provenientes da coleta diferenciada . Campinas 1997. [Dissertação de mestrado - Faculdade de Engenharia Civil da UNICAMP].

6. Alboreda S. Coleta seletiva - Município de São Paulo: estudo detalhado da "coleta seletiva" e do sistema de tratamento dos resíduos sólidos recicláveis da cidade de São Paulo - SP. Versão 2. Fev/1993a. [Relatório integrante da Pesquisa CICLOSOFT promovida pelo CEMPRE - Compromisso Empresarial para Reciclagem].

7. Alboreda S. Estudo detalhado da "coleta seletiva" e do sistema de tratamento dos resíduos sólidos recicláveis do Município de Santo André - SP. 1993b. [Relatório integrante da Pesquisa CICLOSOFT promovida pelo CEMPRE - Compromisso Empresarial para Reciclagem].

8. Assis V. São José dos Campos. In Eigenheer EM, organizador. Coleta seletiva de lixo: experiências brasileiras $N^{0}$ 2. Rio de Janeiro: UFF/CIRS; 1998. p. 61-72

9. Barbosa G. Incineração. In: Jardim NS, coordenadora. Lixo municipal: manual de gerenciamento integrado. São Paulo: IPT/CEMPRE; 1995. p. 219-38. 
10. Barciotte ML. Coleta seletiva e minimização de resíduos sólidos urbanos: uma abordagem integradora. São Paulo; 1993. [Tese de doutorado - Faculdade de Saúde Pública da USP].

11. Bensen G. Embu. In: Eigenheer EM, organizador. Coleta seletiva de lixo experiências brasileiras No 2. Rio de Janeiro: UFF/CIRS; 1998. p. 139-48.

12. Bernareggi GM. Falências do mercado e falências do Estado. Uma introdução. In: Lodovici ES, Bernareggi GM, organizadores. Volume 1: Teoria e prática. Parceria público-privado: cooperação financeira e organizacional entre o setor privado e administradores públicos locais. Tradução de NM Louzada. São Paulo: Summus; 1992. p. $13-26$

13. Biocycle Staff, editors. The biocycle guide to maximum recycling. Emmaus: JG Press; 1995.

14. Blauth P, Leme PCS. USP Recicla. In: Eigenheer EM, organizador. Coleta seletiva de lixo: Experiências Brasileiras $\mathbf{N}^{0}$ 2. Rio de Janeiro: UFF/CIRS; 1998. p. 73-84

15. Brasil. Constituição da República Federativa do Brasil. São Paulo: MEC; 1988.

16. Brasil. Lei no 9.795 de 27 de abril de 1999. Diário Oficial. 28/04/99. Brasília: IN; 1999.

17. Bundesumweltministerium Bioabfall-/Kompostverordnung des Bundes in der Vorbereitung - Bioabfallerfassung hat stark zugenommen. Umwelt 1996a; (10): 338.

18. Bundesumweltministerium Gesamtkosten für die Beseitigung von Siedlungsabfällen (Behandlung und Ablagerung) . Umwelt 1996b (10): 338-40.

19. Bundesumweltministerium. Novellierung der Verpackungsverordnung - Ziele und Eckpunkte. Umwelt 1997 (7/8): 315-6.

20. Calderoni S. Os bilhões perdidos no lixo. $2^{\text {a }}$ ed. São Paulo: Humanitas; 1998.

21. Campinas Lei 9.917 de 26 de novembro de 1998. Diário Oficial do Município de Campinas 27 nov /98. p. 1.

22. Campinas. Lei 6.901 de 07 de janeiro de 1992. Diário Oficial do Município de Campinas, 9 jan 1993. p.3. 
23. Cardoso FG, Terentin L. Campinas. In: Eigenheer EM, organizador. Coleta Seletiva de Lixo: Experiências Brasileiras No 2. Rio de Janeiro: UFF/CIRS; 1998.

24. [CEMPRE] Compromisso Empresarial Para Reciclagem. Guia da coleta celetiva. São Paulo; 1999.

25. CEMPRE Informa. Rio de Janeiro 1998a; (40)

26. CEMPRE Informa. Rio de Janeiro 1998b; (41).

27. CEMPRE Informa. Rio de Janeiro 1998c; (42).

28. [CEMPRE] Compromisso Empresarial Para Reciclagem. Pesquisa Ciclosoft. s.1 .: 1994.

29. Chermont LS, Motta RS. Aspectos econômicos da gestão integrada de resíduos sólidos. São Paulo: IPEA; 1996. [Série Textos Para Discussão, 416].

30. [CMMAD] Comissão Mundial Sobre Meio Ambiente e Desenvolvimento. Nosso futuro comum. 2a. ed. Rio de Janeiro: FGV, 1991.

31. [CNUMAD] Conferência das Nações Unidas Sobre Meio Ambiente e Desenvolvimento (1992 jun 3-14 Rio de Janeiro, Brasil). Agenda 21. São Paulo: Secretaria de Estado do Meio Ambiente; 1997.

32. Cooper J, produtor. Britain and Germany - a comparison of compliance for the EU Packaging Directive. Wastes Manage 1998; Dec: 34-5.

33. Cooper MH. The economics of recycling. CQ Res 1998 (12) : 265-88.

34. Costa ACF e Sattler MA. Catadores informais: elo do processo de coleta dos materiais recicláveis presentes no lixo urbano da cidade de Porto Alegre. In: $\mathbf{2}^{\mathbf{o}}$ Simpósio Internacional de Qualidade Ambiental: Gerenciamento de Resíduos e Certificação Ambiental; 1998 out 26-28; Porto Alegre (RS). s.1. : ABES; 1998. p. 627-32.

35. Dias GF. Atividades interdisciplinares em educação ambiental: manual do professor. São Paulo: Global/Gaia; 1994.

36. Dias GF. Eduacação ambiental: princípios e práticas. 5a. ed. São Paulo: Global; 1998.

37. [DSD] Duales System Deutschland. Wertstoffrecycling in Zahlen - Techniken und Trends. Köln; 1996. 
38. Eigenheer EM, organizador. Coleta seletiva de lixo: experiências brasileiras. Rio de Janeiro: ISER; 1993.

39. Fahrni HP, Gandolla M, Fischer CM, Acaia C. Recent developments in Swiss waste management policy. [Presented at: Vth International Symposium Waste Management Zagreb ‘98 - 25-27.11.98]

40. Ferreira ABH. Dicionário da língua portuguesa. Rio de Janeiro: Nova Fronteira; 1993.

41. Ferreira LC. A questão ambiental. São Paulo: Boitempo; 1998.

42. Fisher J. The road from Rio: sustainable development and the nongovernmental movement in the Third World. Westport (GBR): Praeger; 1993.

42.43. Garcez Filho JM. Administração e organização de um serviço de limpeza pública. In: Seminário Sobre o Problema do Lixo no Meio Urbano; 1965; São Paulo (BR). São Paulo: FSP / USP / OPAS; 1965. p. 43-62.

44. Goldstein N, Genn J. The state of garbage in America - Part II. Biocycle 1997 May: $71-75$.

45. Goldstein N. The state of garbage in America. Biocycle 1997 Apr: 60-7.

46. Hurtado MH. Viviendo dentro de los límites de la Tierra: la búsqueda de un consumo sustentable. In: Consumers International. Consumidores y medio ambiente: satisfacer las necesidades, cambiar los estilos de vida. Trad. A Melnick. s.1.; 1997. p. 10-15.

47. [IBGE] Fundação Instituto Brasileiro de Geografia e Estatística. Pesquisa Nacional de Saneamento. Rio de Janeiro; 1991.

48. Jardim NS, coordenadora. Lixo municipal: manual de gerenciamento integrado São Paulo: IPT/CEMPRE; 1995.

49. Landim L. Para além do mercado e do Estado: filantropia e cidadania no Brasil. Rio de Janeiro: ISER; 1993.

50. Leal J. Aspectos económicos de la gestión de resíduos. In Duran de la Fuente H, compilador. Gestión ambientalmente adecuada de residuos sólidos un enfoque de política integral. S.1: CEPAL / GTZ; 1997. p. 355-413. 
51. Leão AL, Tan IH. Potential of municipal solid waste (MSW) as a source of energy in São Paulo: its impact on CO2 balance. Biomass Bioenergy 1998; 14:83-9.

52. Lima LMQ. Tratamento de lixo. $2^{\text {a }}$ ed. São Paulo: Hemus; 1991.

53. MICT cria Programa Brasileiro de Reciclagem. CEMPRE Inf 1998 (42): 1.

54. Mota S. Urbanização e meio ambiente. Rio de Janeiro: ABES; 1999.

55. Motta MLA. Belo Horizonte. In: Eigenheer EM, organizador. Coleta seletiva de lixo: experiências brasileiras $\mathbf{N}^{0}$ 2. Rio de Janeiro: UFF/CIRS; 1998. p. 89-100.

56. Obladen NL. Coleta seletiva e reciclagem de resíduos sólidos urbanos: alguns modelos conhecidos. In: Trabalhos técnicos do Seminário Internacional sobre Coleta Seletiva e Reciclagem de Resíduos Sólidos Urbanos; 1995 jun 21-24; Marechal Cândido Rondon (PR). 3 vol. s.l.: ABES; 1995. v. 1 p. 63-113.

57. Ogata MG. Os resíduos sólidos na organização do espaço e na qualidade do ambiente urbano: uma contribuição geográfica ao estudo do problema na cidade de São Paulo. Rio de Janeiro: IBGE; 1983.

58. Ojeda MP. Fortalecimiento de capacidades municipales para el manejo de residuos solidos: una funcion del modelo de gestion adoptado. In: $\mathbf{2 6}^{\mathbf{0}}$ Congreso Interamericano de Ingenieria Sanitaria y Ambiental; 1998 nov 1-5; Lima (Peru) [CD-ROM]. Lima: AIDIS; 1998.

59. O'Keefe J, Rice P. The private finance intitiative, waste and local authorities: an outline. Wastes Manage 1998 Sep: 14-5.

60. Oliveira WE. Resíduos sólidos e limpeza pública. In: Philippi Jr. A, organizador. Saneamento do meio. São Paulo: FUNDACENTRO, 1982. p 81-114

60.61. Pereira SA, Santos RF. Porto Alegre. In: EIGENHEER, E.M. (org.) Coleta seletiva de lixo: experiências brasileiras $\mathbf{n}^{0}$ 2. Rio de Janeiro: UFF/CIRS; 1998. p.25-37.

62. Pereira LOM, Tavares AN. Proposta para a gestão integrada dos resíduos sólidos em Belém. In: $1^{\circ}$ Congresso Brasileiro de Engenharia Sanitária e Ambiental; 1997 set 14-19; Foz do Iguaçu (PR) [CD ROM]. Rio de Janeiro: ABES; 1997.

63. Philippi Jr. A. Coleta e transporte de resíduos sólidos no meio urbano. São Paulo; 1979. [Dissertação de Mestrado - Faculdade de Saúde Pública da Universidade de São Paulo] 
64. Porter JW. Trash that recycling plan. The Wall Street Journal, New York, 1993 June 28.

64.65. Portnell F. Integrated waste solutions and the private finance initiative. Wastes Manage 1998 Sep: 16-7.

66. Rocha AA. Fatos históricos do saneamento. São Paulo: Scortecci; 1992.

67. Ruberg C, Aguiar A, Philippi Jr. A. promoção da qualidade ambiental através da reciclagem de resíduos sólidos domiciliares. In: $2^{\circ}$ Simpósio Internacional de Qualidade Ambiental: Gerenciamento de Resíduos e Certificação Ambiental; 1998 out 26-28; Porto Alegre (RS). s.1.: ABES; 1998. p. 163-7.

68. [SMA] Secretaria de Estado do Meio Ambiente. A cidade e o lixo. São Paulo: SMA/CETESB; 1998a.

69. [SMA] Secretaria de Estado do Meio Ambiente. Política Nacional de Resíduos Sólidos. São Paulo: SMA; 1998b. [Apresentada em Reunião Pública - 25/05/98.]

70. [SMA] Secretaria de Estado do Meio Ambiente. Proposta de Política Estadual de Resíduos Sólidos. São Paulo: SMA; 1998c.

71. [SSO] Secretaria de Serviços e Obras. Diretrizes para destinação de resíduos sólidos no município de São Paulo. São Paulo; 1992.

72. [SVMA] Secretaria Municipal do Verde e do Meio Ambiente. Grupo de Trabalho Intersecretarial. Agenda 21 Local. São Paulo; 1996.

73. The Mega Cities Project. Environmental innovations for sustainable mega-cities: sharing approaches that work. New York; 1996.

74. Tosti-Croce AE, Zamora JS, Jourdan R, Gomá JM, Muñoz LR, Gómez P. Reciclaje de desechos sólidos urbanos en Temuco, Chile: tercer año y transferencia al municipio. In: $\mathbf{2 6}^{\mathbf{0}}$ Congreso Interamericano de Ingenieria Sanitaria y Ambiental; 1998 nov 1-5; Lima (Peru) [CD-ROM]. Lima: AIDIS; 1998.

75. Tromans S, Fitzgerald J. Definition of waste: Mayer Parry case confirms Environment Agency approach. Wastes Manage Dec 1998: 41-2.

75.76. [USA] The United States of America. Resource Conservation and Recovery Act of 1976 as amended. In: Hall Jr. Ridgway M, Watson T, Schwartz RE, Bryson NS Davis Jr., Robert C. RCRA hazardous wastes handbook. $8^{\text {th }}$ ed. Rockville (USA): Government Institutes; 1989. p. R1-131. 
77. Viola EJ, Leis HR. A evolução das políticas ambientais no Brasil, 1971-1991: do bissetorialismo preservacionista para o multissetorialismo orientado para o desenvolvimento sustentável. In: Hogan DJ, Vieira, PF organizadores. Dilemas socioambientais e desenvolvimento sustentável. Campinas: UNICAMP; 1995. p. 73-102.

78. Walker J, editor. Local Initiatives: ICLEI members in action 1993-1995. s.1. ICLEI; 1995.

79. Warah R. The partnership principle: key to implementing the Habitat Agenda. Habitat Debate 1997; 3(1): 1-4.

80. Wells C, D’Almeida MLO, Schneider DM. Segregação de materiais. In: Jardim NS, coordenadora. Lixo municipal: manual de gerenciamento integrado. São Paulo: IPT/CEMPRE; 1995. p. 129-42. 


\section{BIBLIOGRAFIA COMPLEMENTAR CONSULTADA}

Amorim WP. Resíduos sólidos urbanos: o problema e a solução. Brasília: Roteiro Editorial; 1996.

Anuatii F. Políticas públicas para reciclagem e reutilização de resíduos. In: Anais do $\mathbf{4}^{\mathbf{0}}$ Encontro Nacional Sobre Gestão Empresarial e Meio Ambiente; 1997 jul 19-21; São Paulo, Brasil. São Paulo: Plêiade; 1997. p. 131-48.

Auf der Kippe : Deutscher Plastikmüll landete illegal in franzözischen Kiesgruber. Der Spiegel 1992; (35):95-6.

Bartelmus P. Environment, growth and development: the concepts and strategies of sustainability. London: Routledge; 1994.

Biddle D. MRF designs around single stream recycling. Biocycle 1998 Aug: 45-9.

Bundesumweltministerium. Verpackungsverordnung endgültig verabschiedet. Umwelt 1991; (6): 266-7.

Capra F. O ponto de mutação. Trad. de A Cabral. São Paulo: Cultrix; 1982.

Carvalho NV. Autogestão: o nascimento das ONGs. 2 a ed. São Paulo: Brasiliense; 1995.

Cavalcanti $\mathrm{C}$, organizador. Meio ambiente, desenvolvimento sustentável e políticas públicas. São Paulo: Cortez; 1997.

[CEMPRE] Compromisso Empresarial Para Reciclagem. Cadernos de reciclagem : o papel da prefeitura. Rio de Janeiro: IBAM / CEMPRE; 1993.

[CEMPRE] Compromisso Empresarial Para Reciclagem. Pesquisa Ciclosoft. s. 1 . : CEMPRE; 1999.

Cunha CB. e col. Serviços de limpeza. In: Jardim NS et al. (org.) Lixo municipal: manual de gerenciamento integrado. São Paulo: IPT / CEMPRE; 1995. p.39-71.

Debray MB. Définition du Déchet. s.1. 1998. [booklet online]. Disponível em : $<$ http://helios.emse.fr/ brodhag/porjelev/dechet12.htm> [24/ jul / 99].

Dubioses Angebot: Neuer Skandal um den "Grünen Punkt" : im Bayerischen wird Plastikmüll verbrannt statt aufbereitet. Der Spiegel 1992; (45):124-7. 
Duran de la Fuente $\mathrm{H}$, compilador. Gestión ambientalmente adecuada de residuos sólidos un enfoque de política integral. s.l: CEPAL / GTZ; 1997.

Eco U. Como se faz uma tese. São Paulo: Cortez; 1991.

Eigenheer EM, organizador. Coleta seletiva de lixo: experiências brasileiras $\mathbf{N}^{\mathbf{0}} 2$. Rio de Janeiro: UFF/CIRS; 1998.

[EPA] Environmental Protection Agency. The consumer's handbook for reducing solid waste. [booklet online]. s.1.; 1992. Disponível em: $<$ http://www.epa.gov/docs/OSWRCRA/non-hw/reduce/catbook/catbook1.txt> [1999 Jul $8]$.

Ferguson J. Partnership in waste management. Wastes Manage 1998 Dec: 37-40.

Ferreira $\mathrm{ABH}$. Dicionário da língua portuguesa. Rio de Janeiro: Nova Fronteira; 1993.

Fiúza SM, Barros RTV. Viabilidade de solução intermunicipal para destinação final de resíduos sólidos. In: $\mathbf{2 6}^{\mathbf{0}}$ Congreso Interamericano de Ingenieria Sanitaria y Ambiental; 1998 nov 1-5; Lima (Peru) [CD-ROM]. Lima: AIDIS; 1998.

Fonseca E. Iniciação ao estudo dos resíduos sólidos e da limpeza pública. João Pessoa: União; 1999.

Forattini OP. Ecologia, epidemiologia e sociedade. São Paulo: Artes Médicas; 1992.

Gomes G. Gerenciamento de resíduos sólidos em Porto Alegre e qualidade de vida. In: $2^{\circ}$ Simpósio Internacional de Qualidade Ambiental: Gerenciamento de Resíduos e Certificação Ambiental.; 1998 out 26-28; Porto Alegre (RS). s.1. : ABES; 1998. p 45558.

Gebara D, Dall'Aglio Sobrinho M. Experiência da implantação de coleta seletiva no município de Ilha Solteira - SP. In: Anais do $\mathbf{2 6}^{\circ}$ Congresso Interamericano de Engenharia Sanitária e Ambiental [CD ROM]; 1993 nov 1-5; Lima, Peru. Lima: AIDIS; 1998.

Guimarães JRL, Pinheiro SB. Coleta seletiva no município do Natal. In: $\mathbf{1 8}^{\circ}$ Congresso Brasileiro de Engenharia Sanitária e Ambiental ;1995 set 17-21; Salvador (BA) [disquete $3 \frac{1}{2} 2^{\prime \prime}$. Rio de Janeiro: ABES; 1995. 
Helfant $\mathrm{H}$, Grandinetti $\mathrm{P}$. O processo informal de coleta seletiva de resíduos sólidos recicláveis: o caso do bairro Cerqueira César. São Paulo; 1998. [Monografia para a disciplina SGA - Seminário de Gestão Ambiental do Curso de Especialização em Gestão Ambiental - Universidade de São Paulo / Faculdade de Saúde Pública / Faculdade de Arquitetura e Urbanismo / Núcleo de Informação em Saúde Ambiental]

Heller L. Saneamento e saúde. Brasília: OPAS/OMS; 1997.

Jacobi PR, editor. Consumo e meio ambiente. Debates Sócio-Ambientais 1997; 2(5).

Lodovici ES, Bernareggi GM, organizadores. Parceria público-privado: cooperação financeira e organizacional entre o setor privado em administrações públicas locais. Trad. NM Louzada. São Paulo: Summus; 1993. 2 volumes.

Medina M. Scavenger cooperatives in developing countries. Biocycle 1998 June: 70-2. Paixão MFM, Almeida MO. Gerenciamento do lixo plástico da Universidade Estadual de Feira de Santana. In: $\mathbf{2 6}^{\mathbf{0}}$ Congreso Interamericano de Ingenieria Sanitaria y Ambiental; 1998 nov 1-5; Lima (Peru) [CD-ROM]. Lima: AIDIS; 1998.

Philippi Jr. A, organizador. Saneamento do meio. São Paulo: FUNDACENTRO, 1982.

Philippi Jr. A, Maglio I, Coimbra JAA, Franco RM, editores. Municípios e meio ambiente: perspectivas para a municipalização da gestão ambiental no Brasil. São Paulo: ANAMMA; 1999.

Quivy R, Campenhoudt LV. Manual de Investigação em ciências sociais. Trad. JM Marques e MA Mendes. Lisboa: Gradiva; 1992.

Reinfeld NV. Sistemas de reciclagem comunitária. Trad. JCB dos Santos. São Paulo: Makron; 1994.

Ruberg C, Philippi Jr. A. O gerenciamento da coleta seletiva em cidades brasileiras. In: $8^{\circ}$ Simpósio Luso-Brasileiro de Engenharia Sanitária e Ambiental; 1998 abr 26-30; João Pessoa (PB). Rio de Janeiro: ABES; 1998. p. 71.

[SMA] Secretaria de Estado do Meio Ambiente. Resíduos sólidos e meio ambiente no Estado de São Paulo. São Paulo; 1993. 
Trabalhos técnicos do Seminário Internacional sobre Coleta Seletiva e Reciclagem de Resíduos Sólidos Urbanos; 1995 jun 21-24; Marechal Cândido Rondon (PR). 3 vol. s.l.: ABES; 1995.

Teixeira BAN, Zanin M. A implantação da coleta seletiva de resíduos sólidos na Universidade Federal de São Carlos - SP: aspectos relevantes do projeto e avaliação preliminar. In: $1^{\circ}$ Congresso Brasileiro de Engenharia Sanitária e Ambiental; 1997 set 14-19; Foz do Iguaçu (PR) [CD-ROM]. Rio de Janeiro: ABES, 1997.

Universidade de São Paulo. Faculdade de Saúde Pública. Biblioteca/CIR. Guia de apresentação de teses. São Paulo: A Biblioteca; 1998.

Viola EJ. O movimento ambientalista no Brasil (1971-1991): da denúncia e conscientização pública para a institucionalização e o desenvolvimento sustentável. In: Goldemberg M, organizador. Ecologia, ciência e política. Rio de Janeiro: Revan; 1992. p. 49-75.

Williams CW. Partnerships, power and participation. Habitat Debate 1997; 3(1):15-6. 


\section{ANEXO 1}

\section{ROTEIRO PARA ENTREVISTAS}

DATA: ___ _ _ INÍCIO____ HS TÉRMINO:__ _ _ HS

Identificação do Programa na Pesquisa:

Nome da Instituição/Organização:

Nome do(s) representante(s): 1)

(cargo ou função:

2)

(cargo ou função:

3)

(cargo ou função: )

Atividade principal da entidade:

Atividades envolvidas no gerenciamento de resíduos: 


\section{A. MOBILIZAÇÃO E IMPRESSÕES GERAIS}

A.1. Fale sobre a participação da entidade no Gerenciamento de Resíduos Sólidos Domésticos (iniciativa, objetivos, responsabilidades, benefícios, etc.)

A.2. Você acha que sem a sua participação o programa funcionaria?

SIM TALVEZ NÃO

A.3. Sem a existência do programa sua atividade seria viável?

SIM

TALVEZ NÃO

A.4. Como você avalia a situação atual do programa?

BOA REGULAR RUIM NÃO SABE

A.5. Como você resumiria as dificuldades para participar do programa?

A.6. Quais seriam as principais soluções?

A.7. Como você vê o futuro do programa? 


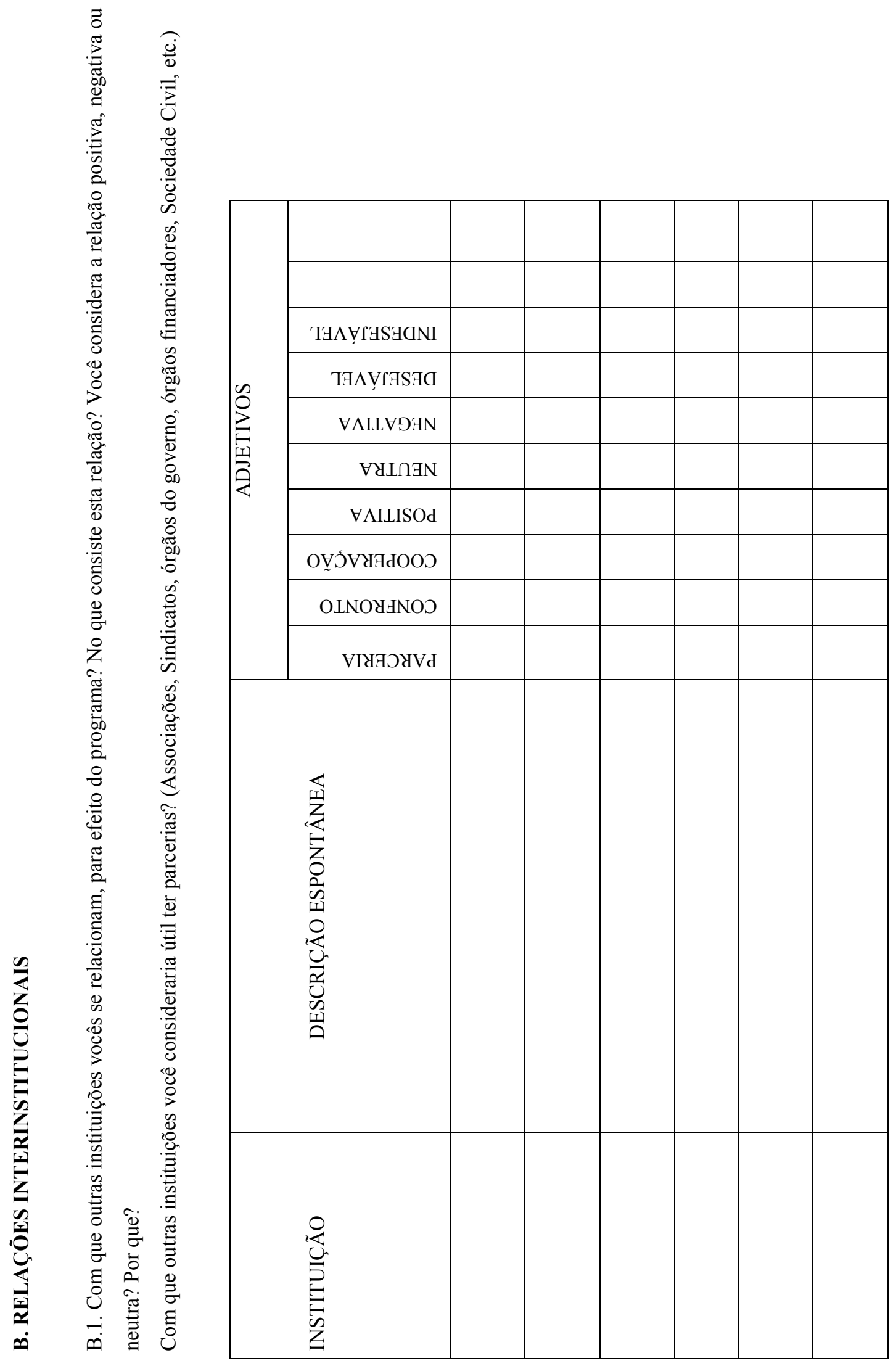




\section{DESCRIÇÃO OPERACIONAL}

C.1.. Como os resíduos chegam até vocês? Quem traz, de onde vem?

C.2. Por favor, dê alguns detalhes dos resíduos que vocês recebem:

\begin{tabular}{|l|l|l|l|}
\hline TIPO DE RESÍDUO & QUANTID & UNIDADE & VALOR DE COMPRA \\
\hline & & & \\
\hline & & & \\
\hline & & & \\
\hline & & & \\
\hline & & & \\
\hline & & & \\
\hline
\end{tabular}

C.3. Por favor, descreva sucintamente os processos pelos quais os resíduos passam:

\begin{tabular}{|l|l|}
\hline TIPO DE RESÍDUO & PROCESSOS \\
\hline & \\
\hline & \\
\hline & \\
\hline & \\
\hline & \\
\hline & \\
\hline
\end{tabular}


C.4. Quantas pessoas estão envolvidas?

\begin{tabular}{|l|l|l|l|}
\hline FUNÇÕES & & & $\mathrm{N}^{\mathbf{0}}$ \\
\hline OPERACIONAIS & & ADMINISTRATIVOS & \\
\hline & & & \\
\hline & & & \\
\hline & & & \\
\hline & & & \\
\hline TOTAL & & & \\
\hline
\end{tabular}

C.5. Por favor, dê alguns detalhes sobre os materiais após seu processamento, as quantidades e os valores de venda, quando for o caso:

\begin{tabular}{|l|l|l|l|}
\hline TIPO DE RESIDUO & QUANTID & UNIDADE & VALOR DE VENDA \\
\hline & & & \\
\hline & & & \\
\hline & & & \\
\hline & & & \\
\hline & & & \\
\hline & & & \\
\hline & & & \\
\hline
\end{tabular}

\section{ASPECTOS ECONÔMICOS}

D.1. Para a sua entidade, o programa atualmente é viável economicamente?
SIM
EXISTEM DÚVIDAS
NÃO. NÃO SABE

Comentários:

D.2. Qual foi o investimento para a implantação do programa?

D.3.Qual a origem do dinheiro para investimento? 
D.4. Custo de manutenção do programa (mensal)

D.5. Faturamento do programa (mensal)

E. ASPECTOS AMBIENTAIS E DE SAÚdE PÚBLICA

E.1. Há alguma ação no sentido de evitar o aparecimento de moscas, mosquitos, ratos e baratas? Eles têm aparecido?

Por favor, comente: 


\section{UNIVERSIDADE DE SÃO PAULO FACULDADE DE SAÚDE PÚBLICA DEPARTAMENTO DE SAÚDE AMBIENTAL}

Av. dr. Arnaldo, 715 - São Paulo - SP - Tel. 3066-7712

Ilmo. Sr. (a)

São Paulo, de de $199 \ldots$

Prezado(a) Senhor(a):

Para fins de trabalho acadêmico de pós-graduação, estamos realizando uma série de entrevistas com pessoas que trabalham em empresas, entidades e instuições envolvidas direta ou indiretamente em gerenciamento de resíduos sólidos domésticos. Esta pesquisa tem o objetivo de analisar a participação das entidades e instituições no gerenciamento de resíduos sólidos domésticos, suas dificuldades e as soluções criativas que encontram.

Pelas informações prévias que obtivemos sobre o trabalho desta instituição, seria extremamente valioso para nós contar com dados desta instituição, e por isto solicitamos sua colaboração no sentido de viabilizar as entrevistas necessárias, e autorização para publicação dos dados coletados.

Esclarecemos que não estamos avaliando individualmente o comportamento de pessoas, portanto nos comprometemos a manter total respeito e sigilo quanto aos nomes das pessoas entrevistadas, bem como sobre seus dados pessoais.

Permanecemos à disposição para esclarecer eventuais dúvidas.

Gratos,

Arlindo Philippi Jr.

Orientador
Alexandre Aguiar.

Pesquisador 


\title{
DECLARAÇÃO DE CONSENTIMENTO ESCLARECIDO (INSTITUIÇÃO)
}

\author{
São Paulo, de de 1998.
}

Eu,

R.G. , responsável pelo (a)

declaro para os devidos fins que autorizo a utilização dos dados coletados nas atividades de pesquisa em nossa entidade e entrevistas com nossos colaboradores realizadas pelo sr. Alexandre de Oliveira e Aguiar, para fins de trabalhos acadêmicos e publicações, sem restrições de prazos e citações, desde a presente data.

Abdicando de direitos meus e de meus sucessores, subscrevo a presente.

Data e local, 


\title{
DECLARAÇÃO DE CONSENTIMENTO ESCLARECIDO (INDIVIDUAL)
}

São Paulo, de de 1998.

\begin{abstract}
Eu, (nome)

(doc. Identidade) , declaro para os devidos fins que autorizo a utilização

dos dados coletados na entrevista realizada nesta data pelo sr. Alexandre de Oliveira e Aguiar, para fins de trabalhos acadêmicos e publicações, sem restrições de prazos e citações, desde a presente data.
\end{abstract}

Abdicando de direitos meus e de meus sucessores, subscrevo a presente.

Data e local, 
Fórmulas para cálculo de indicadores 
ANEXO 2

FORMULÁRIO - CÁLCULOS DE INDICADORES

A) Eficiência da mão-de-obra de coleta (t / pessoa h)

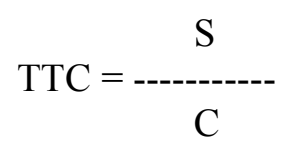

onde:

$\mathrm{C}=$ número de pessoas que trabalham na coleta (inclusive motorista)

$\mathrm{S}=$ quantidade de material coletado ( $\mathrm{t} / \mathrm{mês})$

B) Taxa de desvio (\%)

$$
\mathrm{TD}=\frac{\mathrm{S}}{\mathrm{S}+\mathrm{R}}
$$

onde :

$\mathrm{S}=$ resíduos da coleta seletiva ( $\mathrm{t} / \mathrm{mês})$

$\mathrm{R}=$ resíduos da coleta regular ( $\mathrm{t} / \mathrm{mês})$.

C) Aproveitamento dos veículos (t / veículo h)

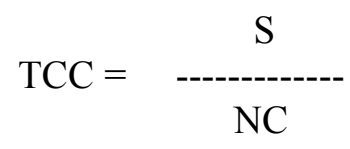

Onde:

$\mathrm{NC}=$ número de caminhões a serviço do programa 
$\mathrm{S}=$ quantidade de material coletado ( $\mathrm{t} / \mathrm{mês})$

\section{C) Eficiência de mão-de-obra de triagem (t / pessoa .h)}

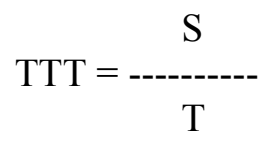

onde

TTT $=$ número de pessoas que trabalham na triagem de uma tonelada $/$ mês

$\mathrm{T}=$ número de pessoas que trabalham em triagem

$\mathrm{S}=$ quantidade de material triado ( $\mathrm{t} / \mathrm{mês})$

\section{D) Taxa de recuperação (\%)}

$$
\mathrm{TD}=\frac{\text { REC }}{\text { REF }}
$$

onde :

REC = quantidade de resíduos recuperada, incluindo reuso, reciclagem e compostagem (t/mês)

$\mathrm{REF}=$ quantidade de resíduos de referência ( $\mathrm{t} / \mathrm{mês})$.

\section{E) Custos unitários (R\$ / t)}

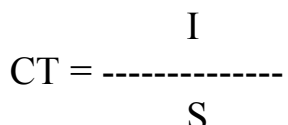


Onde:

$\mathrm{I}=$ Custos totais incorridos (R $\$ /$ mês $)$

$\mathrm{S}=$ Quantidade de resíduos ( $\mathrm{t} / \mathrm{mês})$

F) Porcentagem de cada material nos materiais vendidos:

$$
\text { pi }=\frac{\text { M }}{\mathrm{V}}
$$

Onde:

$\mathrm{M}=$ quantidade vendida do material ( $\mathrm{t} / \mathrm{mês})$

$\mathrm{V}=$ somatória dos materiais vendidos ( $\mathrm{t} / \mathrm{mês})$

G) Porcentagem do faturamento devida a um material (\%):

$$
\text { fi }=\frac{\text { M x P }}{\text { F }}
$$

onde

$\mathrm{M}=$ quantidade vendida do material ( $\mathrm{t} /$ mês $)$

$\mathrm{P}=$ preço do material $(\mathrm{R} \$ / \mathrm{t})$

$\mathrm{F}=$ faturamento total do programa com todos os materiais ( $\mathrm{R} \$$ / mês) 


\section{ANEXO III}

Resumos das relações inter-institucionais dos

programas 


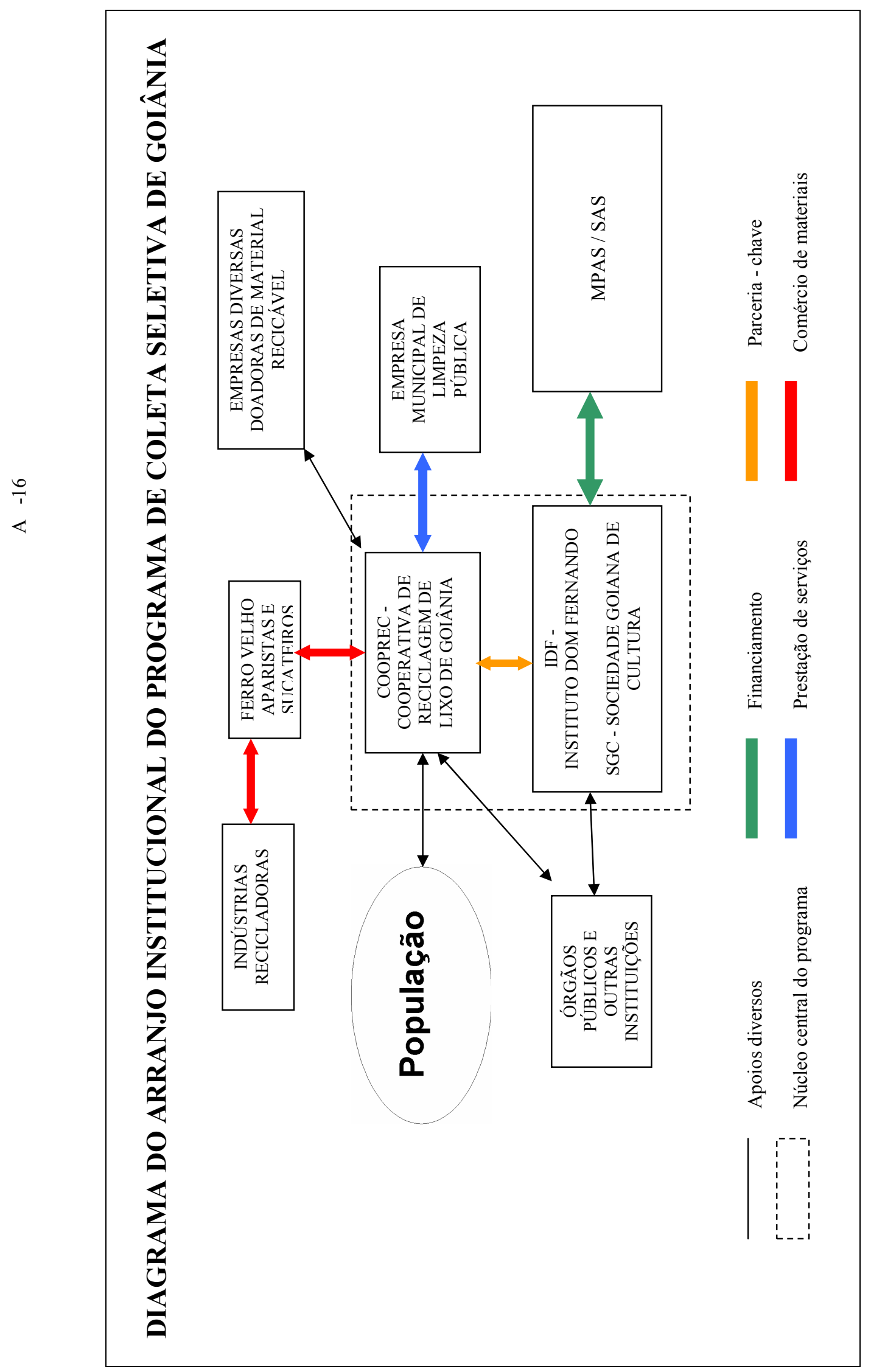




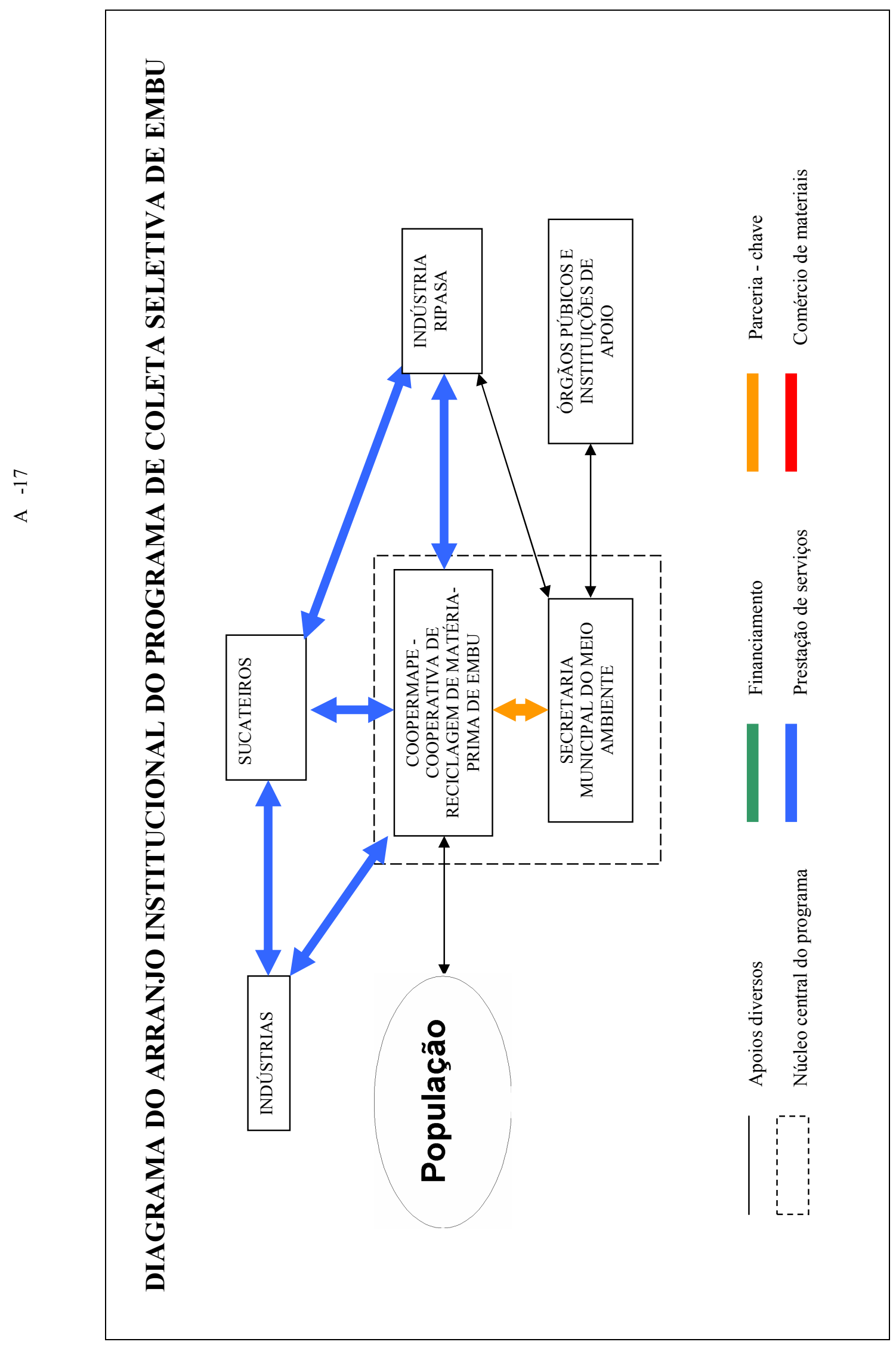




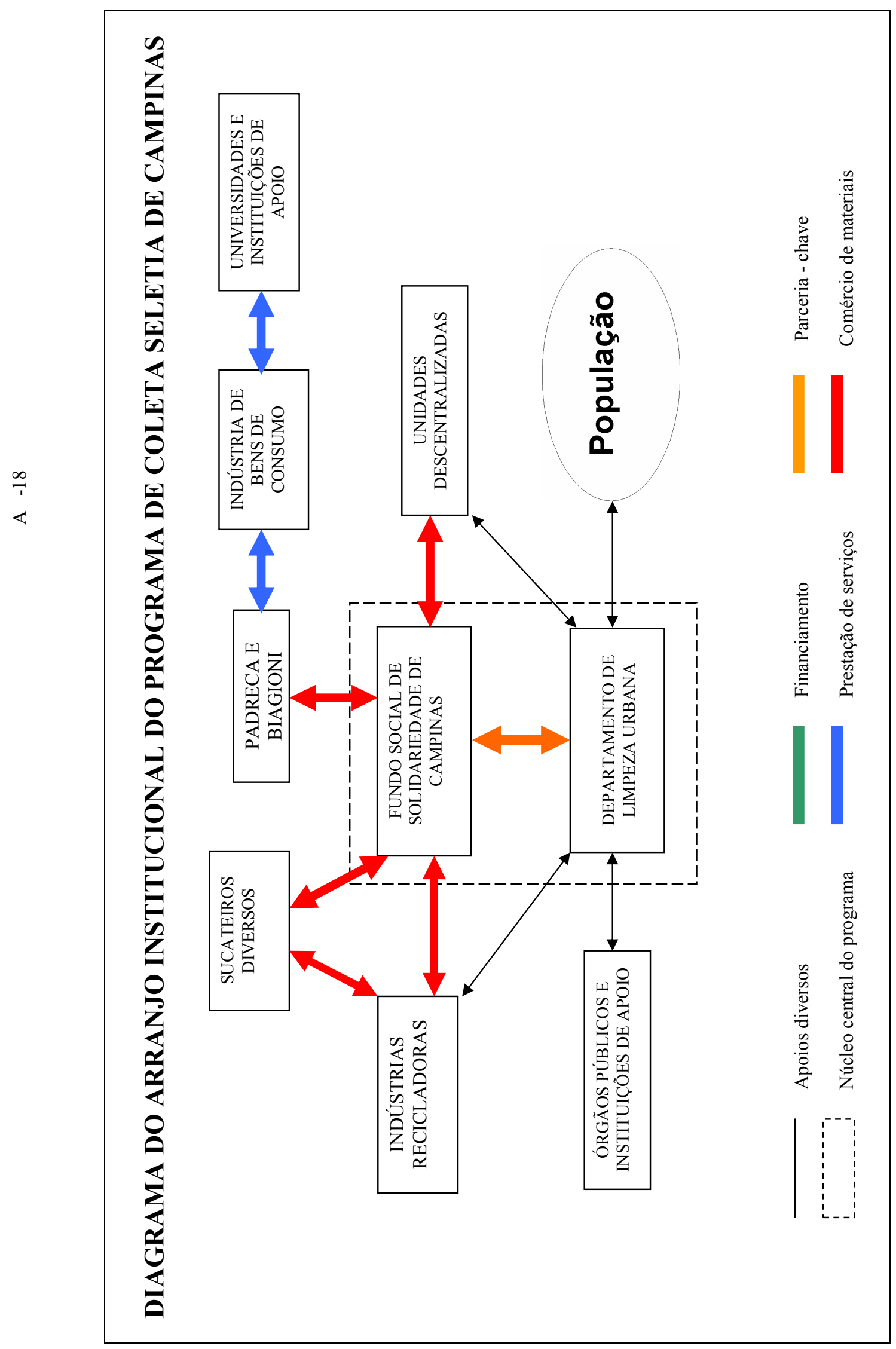




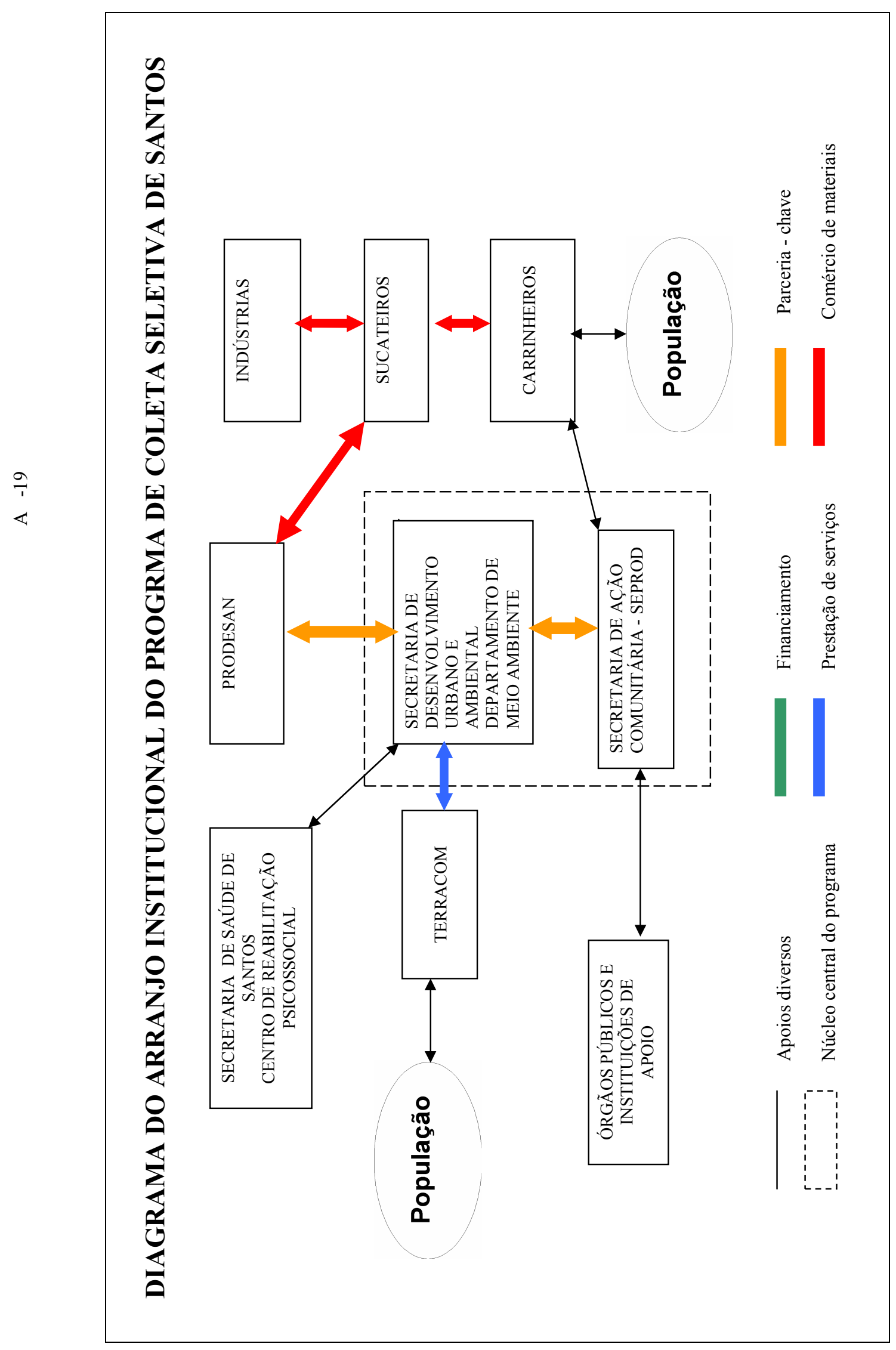




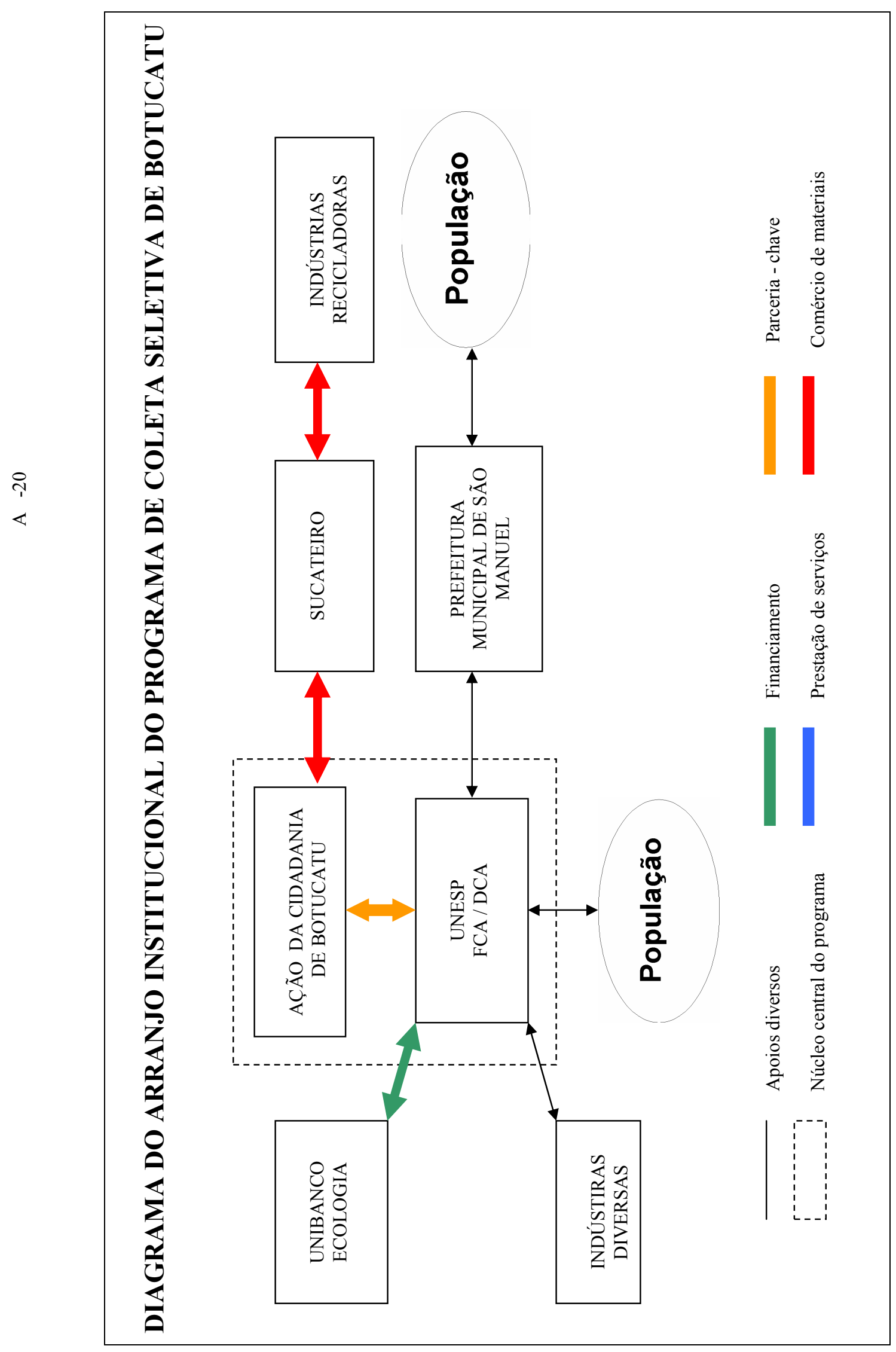




\section{ANEXO IV}

Resumos dos fluxos de material dos programas 


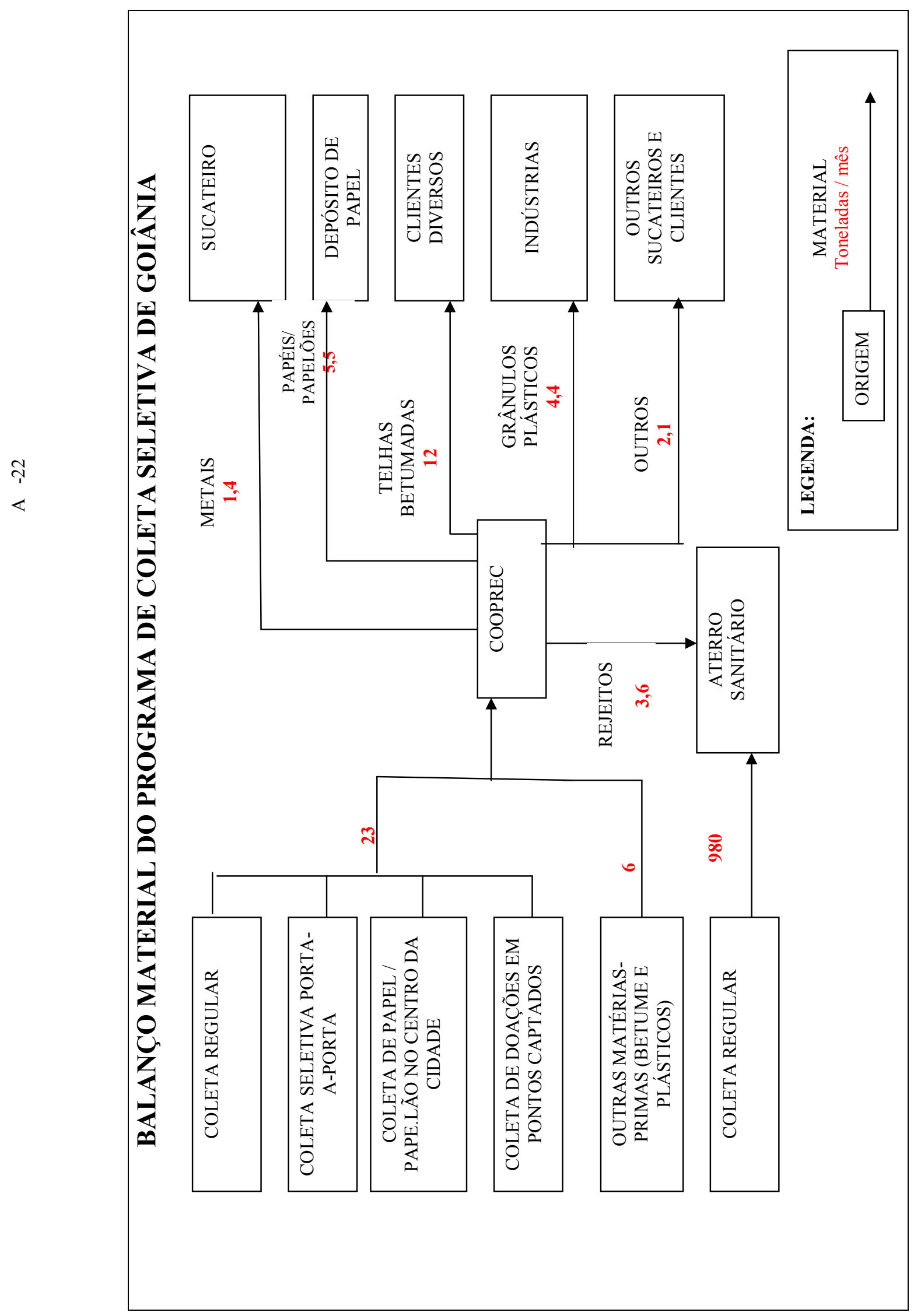




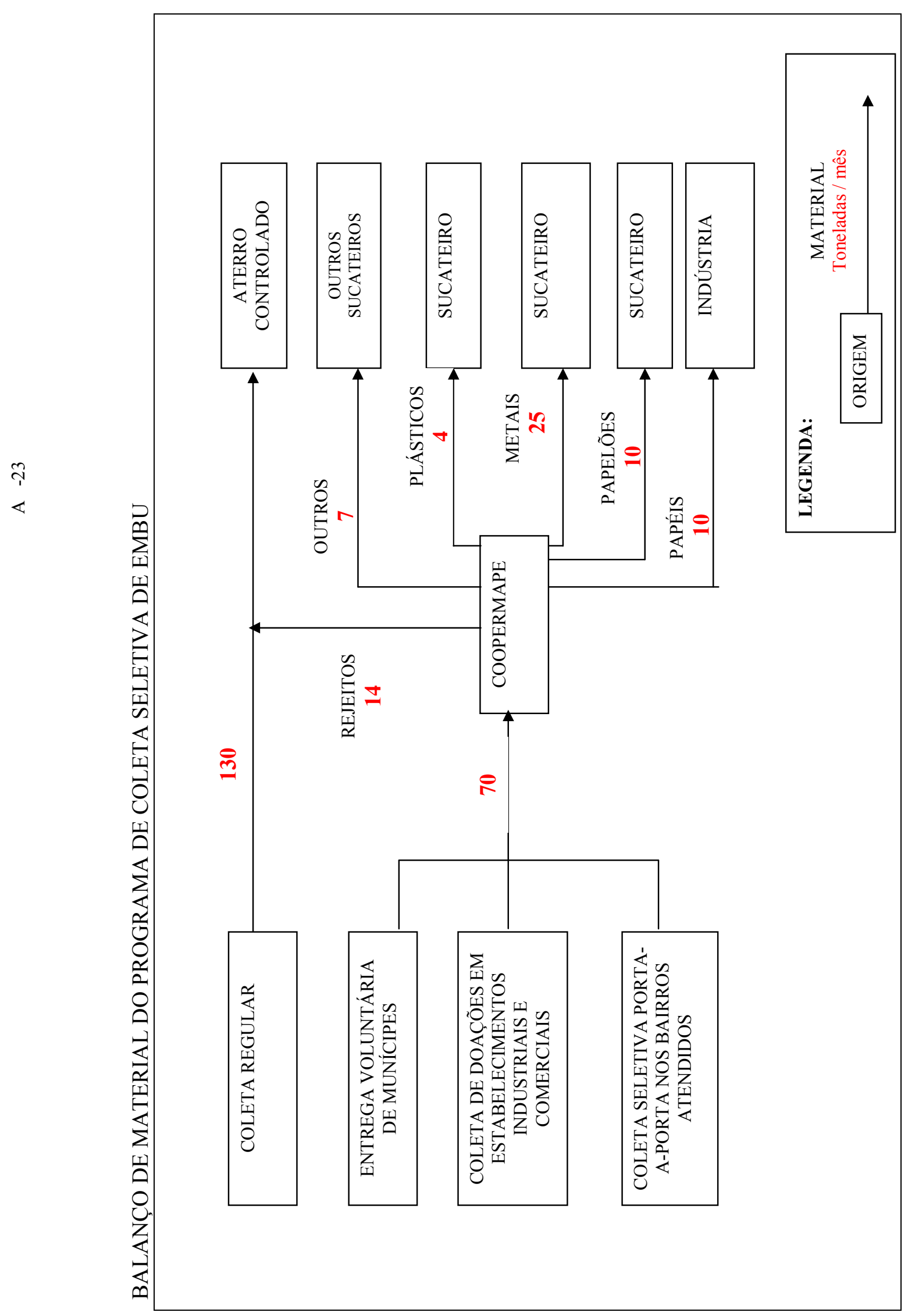




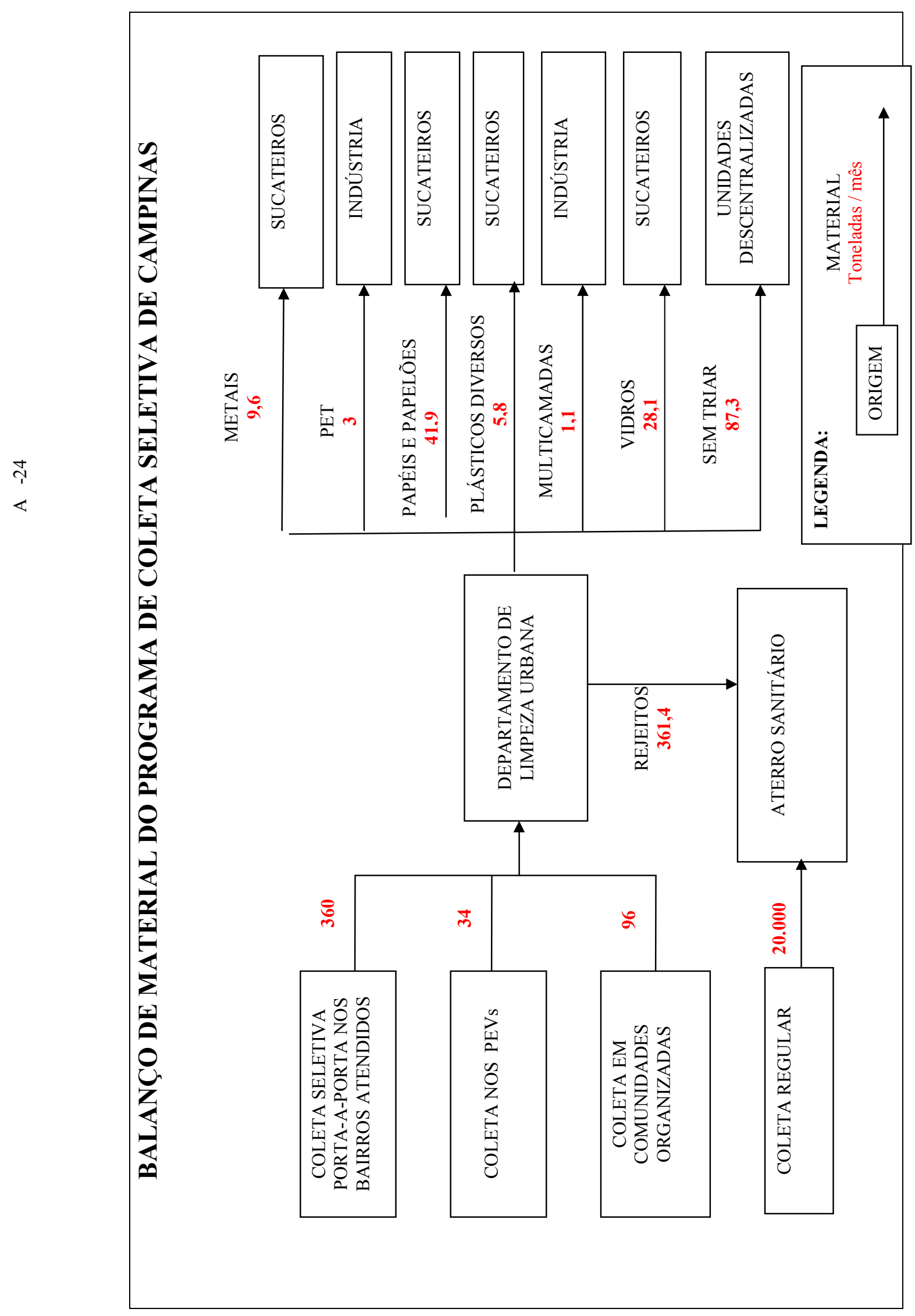




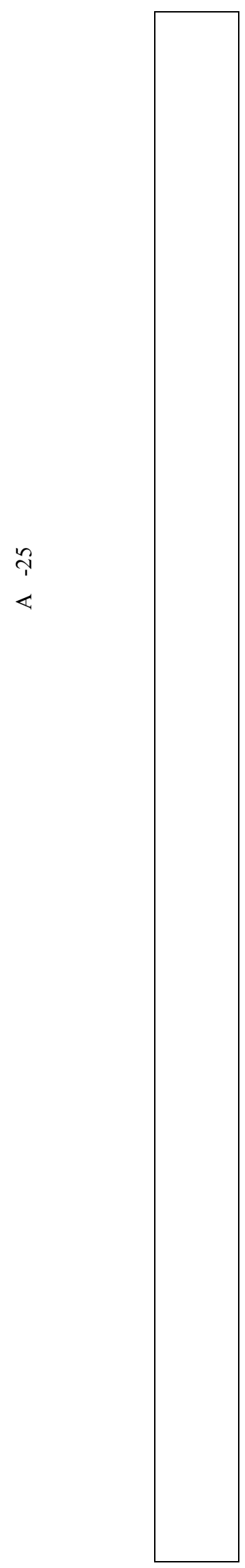




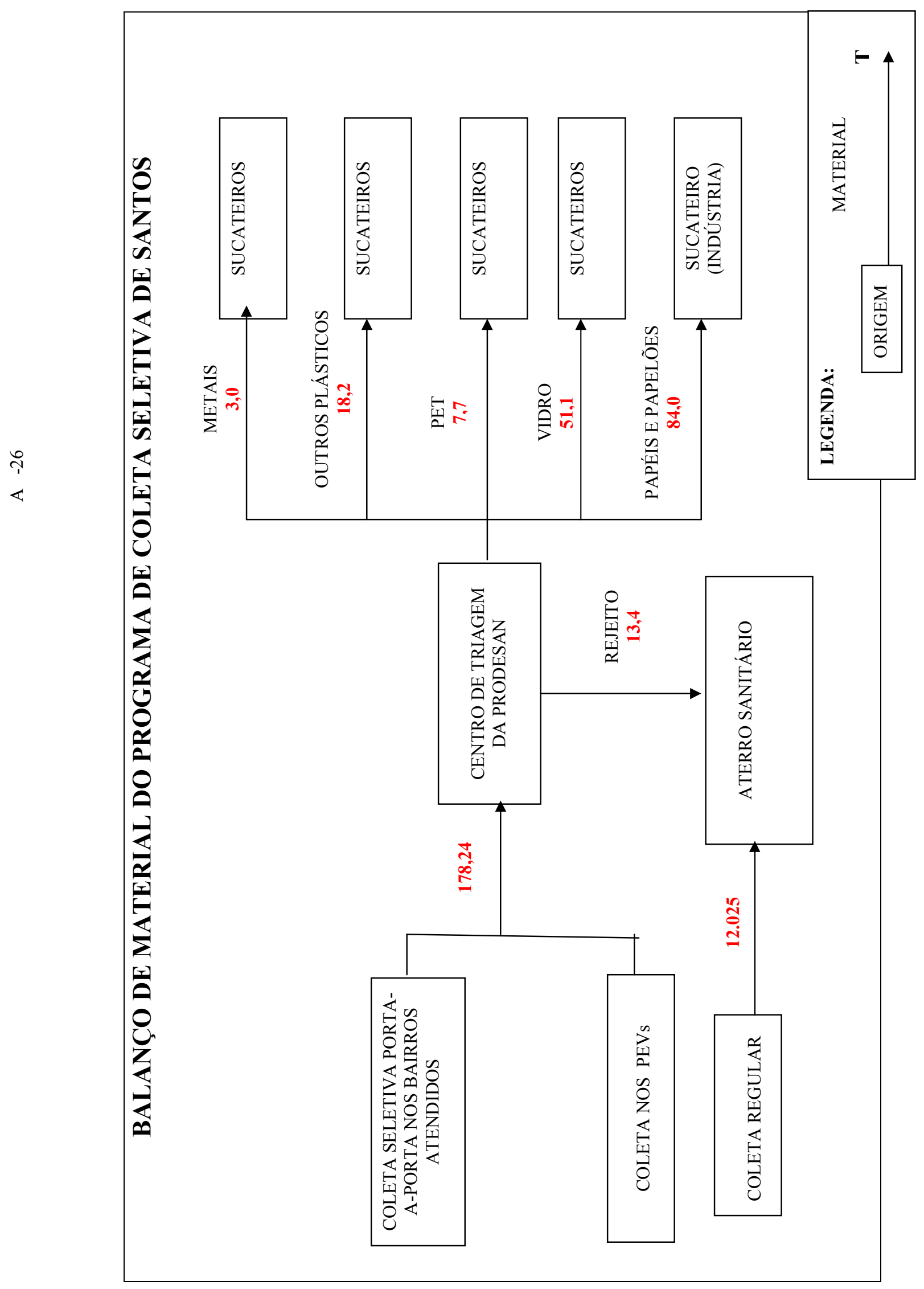




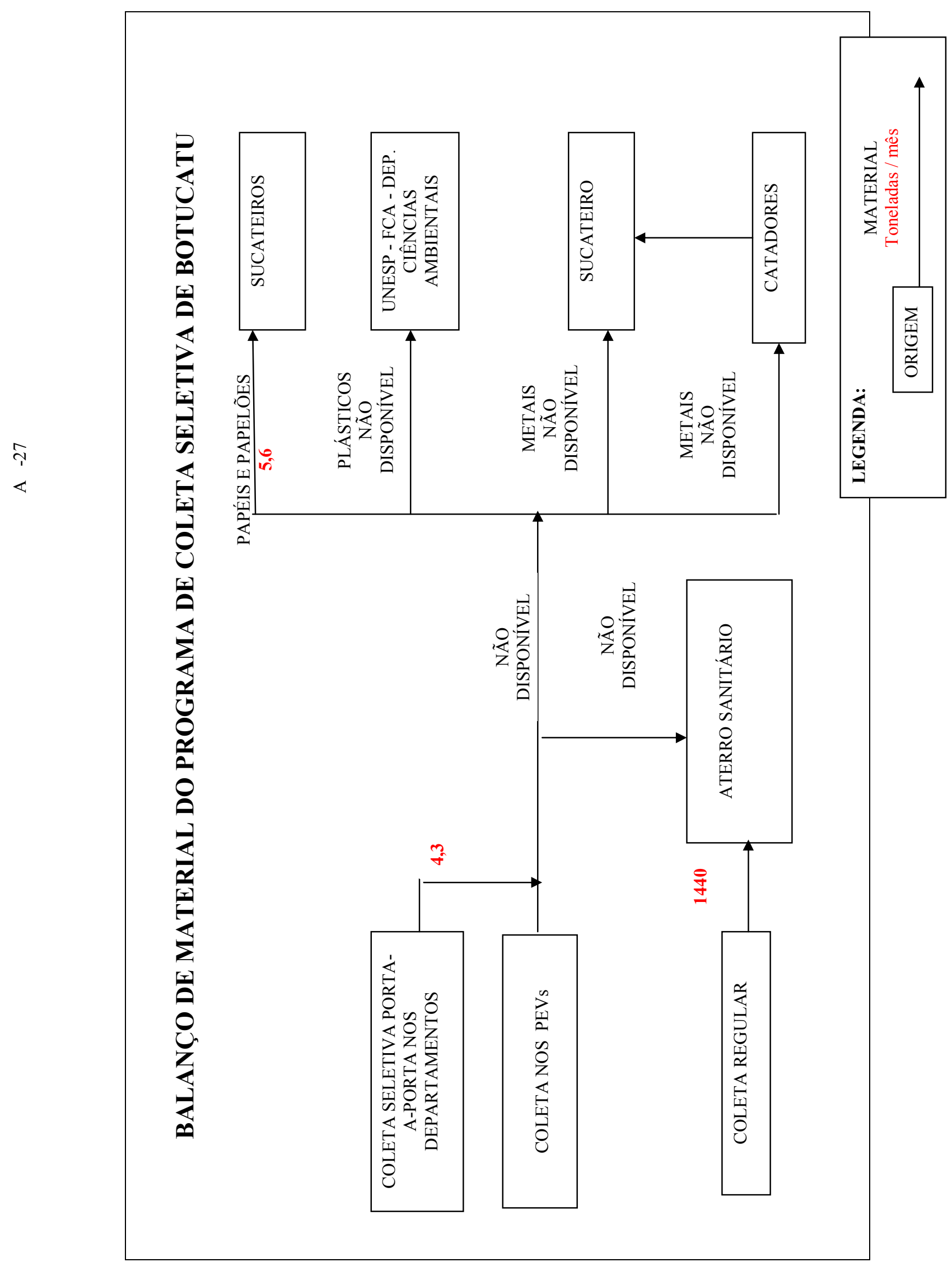




\section{ANEXO V}

\section{Dados tabulares das entrevistas}




\section{DADOS TABULADOS DAS ENTREVISTAS}

Tabela A5.1. Distribuição percentual das respostas dos entrevistados à pergunta:

"Sem a sua participação o programa seria viável?"

\begin{tabular}{l|r|r|r|r|rl}
\hline & Sim & Talvez & Não & N.R & Total \\
\hline Embu & 60,0 & 20,0 & 20,0 & 0 & 100 \\
Goiânia & 50,0 & - & 50,0 & 0 & 100 \\
Campinas & 50,0 & 16,7 & 33,3 & 0 & 100 \\
Santos & 25,0 & - & 50,0 & 25,0 & 100 \\
Botucatu & 33,3 & - & 33,3 & 33,3 & 100 \\
\hline Total & 45,8 & 8,3 & 37,6 & 8,3 & 100 \\
\hline
\end{tabular}

Tabela A5.2. Distribuição percentual das respostas dos entrevistados à pergunta "Sem o programa a sua atividade seria viável?

\begin{tabular}{l|r|r|r|r|c}
\hline & Sim & Talvez & Não & N.R. & Total \\
\hline Embu & 80,0 & - & 20,0 & - & 100 \\
Goiânia & 83,3 & - & - & 17,7 & 100 \\
Campinas & 66,7 & - & - & 33,3 & 100 \\
Santos & 75,0 & - & - & 25,0 & 100 \\
Botucatu & 66,7 & - & 33,3 & - & 100 \\
\hline Total & 75 & - & 8,3 & 16,7 & 100 \\
\hline
\end{tabular}

Tabela A5.3. Dificuldades enfrentadas nos programas, citadas pelos entrevistados.

\begin{tabular}{|c|c|}
\hline DESCRIÇÃO & FREQUENNCIA \\
\hline $\begin{array}{l}\text { Inadimplência de } \\
\text { compradores }\end{array}$ & $\begin{array}{l}1 \\
2\end{array}$ \\
\hline Preços de mercado & 2 \\
\hline Impostos & 3 \\
\hline Falta de verbas & 3 \\
\hline Equipamentos ausentes / inadequados & 2 \\
\hline Falta de mão-de-obra especializada & 1 \\
\hline Regulação municipal do trânsito & 2 \\
\hline Relações entre entidades & 3 \\
\hline Envolvimento da comunidade & 1 \\
\hline Burocracia interna / cultura institucional & 1 \\
\hline Divulgação / propaganda & 3 \\
\hline Vontade política & 2 \\
\hline Capacitação de carrinheiros/catadores & 2 \\
\hline Falta de visibilidade dos benefícios & \\
\hline
\end{tabular}


Tabela A5.4. Listagem das principais soluções indicadas pelos entrevistados

Formar multiplicadores
Envolver cidadãos da $3^{\text {aidade }}$ Aquisição de equipamentos
Apoio da mídia
Doação de equipamentos
Novo centro de triagem
Vontade Política
Intervenção (ação direta de organização de uma entidade por outra)
Troca de informações
Atuação integrada dos órgãos
União das pessoas que trabalham
Coleta seletiva em edifícios
Apoio de órgãos de capacitação
Aumento de pessoal
Qualificação das pessoas
Apoio gerencial para cooperativa
Privatização
Isenção fiscal
Subsídio para montar estrutura
Recursos do exterior
Melhoria da economia geral
Educação
Conscientização dos técnicos


Tabela A5.5. Distribuição percentual das respostas

à pergunta:

"Como você avalia a situação atual do programa?

\begin{tabular}{l|c|c|c|c|c}
\hline Município & boa & regular & ruim & $\begin{array}{l}\text { Não } \\
\text { sabe }\end{array}$ & Total \\
\hline Embu & 80,0 & 20,0 & - & - & 100 \\
Goiânia & 50,0 & 33,3 & - & 16,7 & 100 \\
Campinas & 33,3 & 50,0 & - & 16,7 & 100 \\
Santos & 25,0 & 50,0 & 25,0 & - & 100 \\
Botucatu & - & 33,3 & 33,3 & 33,3 & 100 \\
\hline Total & 41,7 & 37,5 & 16,7 & 12,6 & 100 \\
\hline
\end{tabular}

Tabela A5.6. Distribuição percentual das Respostas à pergunta:

"Como você vê o futuro do programa?"

\begin{tabular}{l|c|c|c|c|c}
\hline Município & Otimista & incerto & Pessimista & NR & Total \\
\hline Embu & 40,0 & 40,0 & 20,0 & 0 & 100 \\
Goiânia & 66,6 & 16,7 & 16,7 & 0 & 100 \\
Campinas & 66,7 & 33,3 & 0 & 0 & 100 \\
Santos & 50,0 & 0 & 50,0 & 0 & 100 \\
Botucatu & 66,7 & 0 & 0 & 33,3 & 100 \\
\hline Total & 58,3 & 20,8 & 16,7 & 4,2 & 100 \\
\hline
\end{tabular}

Tabela A5.7. Participações desejáveis, segundo os entrevistados

\begin{tabular}{|c|c|}
\hline Indicado & Papel \\
\hline Secret. Est. M. Ambiente & "adotar", apoio financeiro e técnico. \\
\hline CEMPRE & atuação política para criação de incentivos fiscais \\
\hline Órgãos de financiamento (3) & apoio financeiro \\
\hline Indústrias & parcerias técnicas e comerciais \\
\hline Imprensa & campanha educativa \\
\hline Instituições de Ensino & apoio técnico (2) \\
\hline & apoio educativo \\
\hline órgãos estaduais & Apoio \\
\hline Empresários & apoio financeiro \\
\hline Orgão munic. Meio Ambiente & apoio geral \\
\hline Sec. Munic. Meio Ambiente & educação ambiental \\
\hline
\end{tabular}


Tabela A5.8. Tipo, freqüência, horário e ponto de coleta em cada programa

\begin{tabular}{|l|l|l|l|l|l|}
\hline Programa & Tipo de coleta & Freqüência & Horário & Ponto & Operador \\
\hline Santos & $\begin{array}{l}\text { Porta-a-porta } \\
\text { PEV }\end{array}$ & semanal & diurno & $\begin{array}{l}\text { Calçada } \\
\text { PEV }\end{array}$ & $\begin{array}{l}\text { Empresa } \\
\text { Particular }\end{array}$ \\
\hline Embu & $\begin{array}{l}\text { Porta-a-porta } \\
\text { Especiais }\end{array}$ & $\begin{array}{l}\text { semanal } \\
\text { conforme } \\
\text { programação }\end{array}$ & $\begin{array}{l}\text { diurno } \\
\text { diário }\end{array}$ & $\begin{array}{l}\text { Calçada } \\
\text { Variável }\end{array}$ & Cooperativa \\
\hline Campinas & $\begin{array}{l}\text { porta-a-porta } \\
\text { PEVs } \\
\text { comunidades } \\
\text { diário } \\
\text { semanal }\end{array}$ & $\begin{array}{l}\text { diurno } \\
\text { diurno } \\
\text { diurno / } \\
\text { noturno }\end{array}$ & $\begin{array}{l}\text { Calçada } \\
\text { PEV } \\
\text { Variável }\end{array}$ & DLU \\
\hline Goiânia & $\begin{array}{l}\text { porta-a-porta } \\
\text { eomercial }\end{array}$ & $\begin{array}{l}3 \text { x por semana } \\
\text { diário } \\
\text { conforme } \\
\text { programação }\end{array}$ & $\begin{array}{l}\text { diurno } \\
\text { noturno } \\
\text { diurno }\end{array}$ & $\begin{array}{l}\text { Calçada } \\
\text { Calçada } \\
\text { Variável }\end{array}$ & Cooperativa \\
\hline Botucatu & PEVs & semanal & diário & PEV & $\begin{array}{l}\text { Transportador } \\
\text { contratado }\end{array}$ \\
\hline
\end{tabular}

Tabela A5.9. Viabilidade econômica do programa do ponto de vista dos entrevistados.

\begin{tabular}{l|l|l|l|l|l}
\hline Município & \multicolumn{5}{|l}{$\begin{array}{l}\text { Para a sua entidade, o programa atualmente é } \\
\text { viável economicamente? }\end{array}$} \\
\hline & Sim & dúvidas & Não & $\begin{array}{l}\text { não sabe } \\
\text { não } \\
\text { resp. }\end{array}$ & Total \\
\hline Embu & 60,0 & 20,0 & 20,0 & - & 100 \\
\hline Goiânia & 66,6 & 16,7 & 16,7 & - & 100 \\
\hline Campinas & 50,0 & 16,7 & - & 33,3 & 100 \\
\hline Santos & 25,0 & - & 50,0 & 25,0 & 100 \\
\hline Botucatu & 333,3 & 33,3 & - & 33,4 & 100 \\
\hline Total & 50,0 & 16,7 & 16,7 & 16,6 & 100
\end{tabular}

Tabela A5.10. Distribuição percentual das informações sobre presença anterior ou atual de vetores nas entidades entrevistadas.

\begin{tabular}{l|c|c|c|c|c|}
\hline Questões & Roedores & $\begin{array}{l}\text { Moscas e } \\
\text { baratas }\end{array}$ & Mosquitos & Nenhum & Total \\
\hline Embu & 25,0 & - & - & 75,0 & 100 \\
Campinas & 25,0 & - & - & 75,0 & 100 \\
Goiânia & 25,0 & 25,0 & 25,0 & 25,0 & 100 \\
Santos & - & 50,0 & - & 50,0 & 100 \\
Botucatu & - & - & - & 100,0 & 100 \\
\hline Total & 21,4 & 14,4 & 7,1 & 57,1 & 100 \\
\hline
\end{tabular}


Tabela A5.11. Distribuição percentual das informações dos entrevistados sobre medidas preventivas para evitar a proliferação de vetores.

\begin{tabular}{l|c|c|c|c}
\hline Questões & $\begin{array}{l}\text { Há medidas } \\
\text { preventivas }\end{array}$ & $\begin{array}{l}\text { Não há medidas } \\
\text { preventivas }\end{array}$ & $\begin{array}{l}\text { Não } \\
\text { especificaram }\end{array}$ & Total \\
\hline Embu & 60,0 & - & 40,0 & 100 \\
Campinas & 66,7 & - & 33,3 & 100 \\
Goiânia & 25,0 & 50,0 & 25,0 & 100 \\
Santos & 100,0 & - & - & 100 \\
Botucatu & - & - & 100,0 & 100 \\
\hline Total & 50,0 & 14,3 & 35,7 & 100 \\
\hline
\end{tabular}




\section{ANEXO VII}

\section{Material de divulgação dos programas}




\section{ANEXO VIII}

Modelos de cartas de apresentação e de consentimento esclarecido 


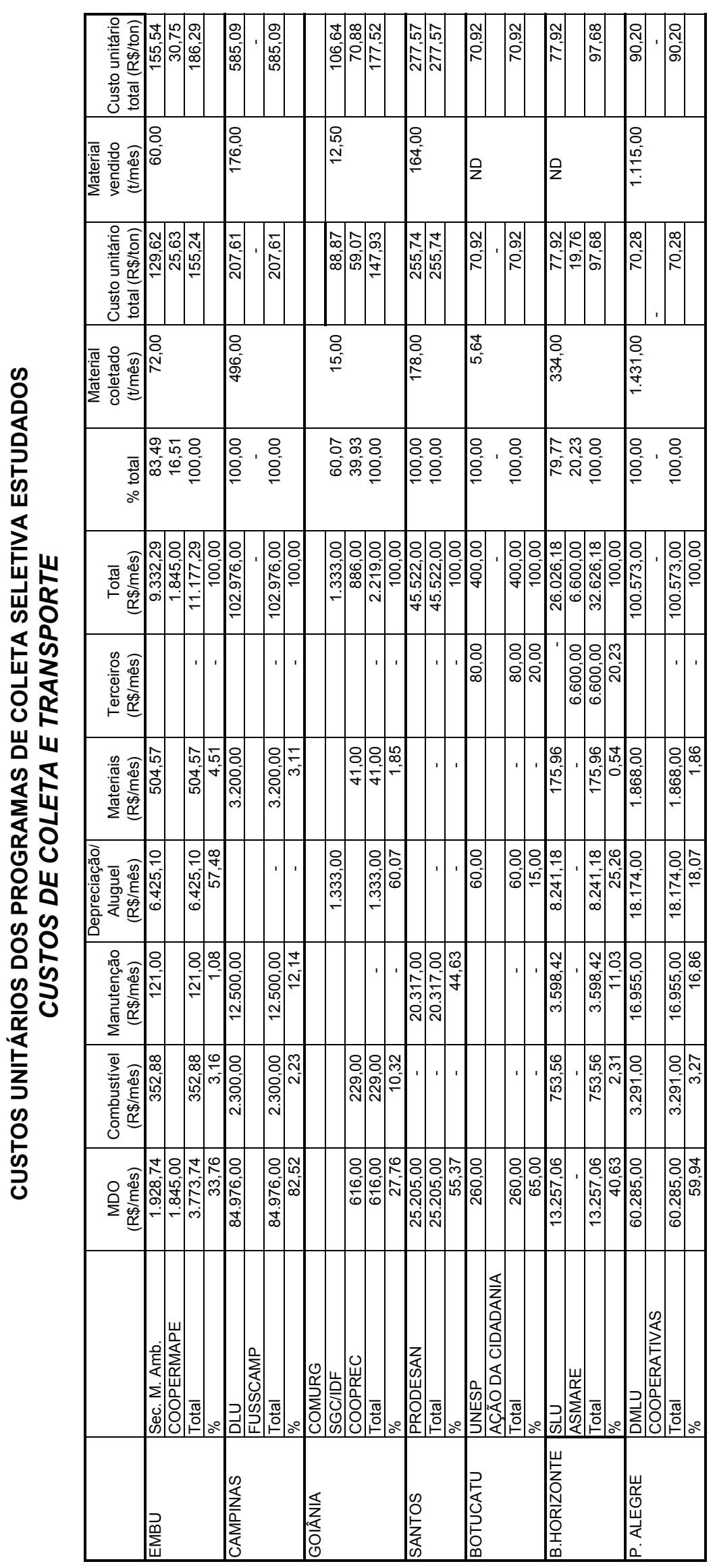




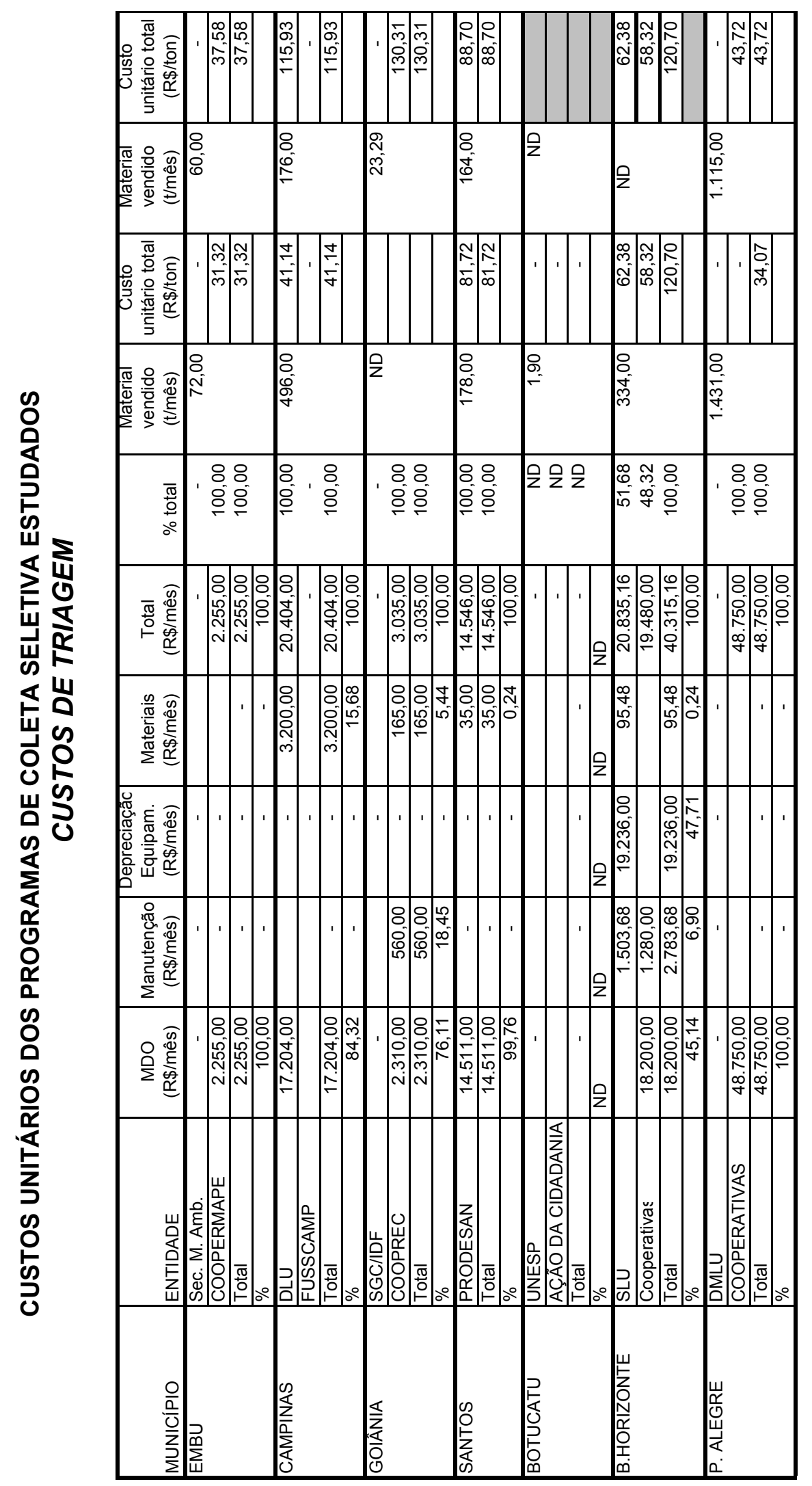




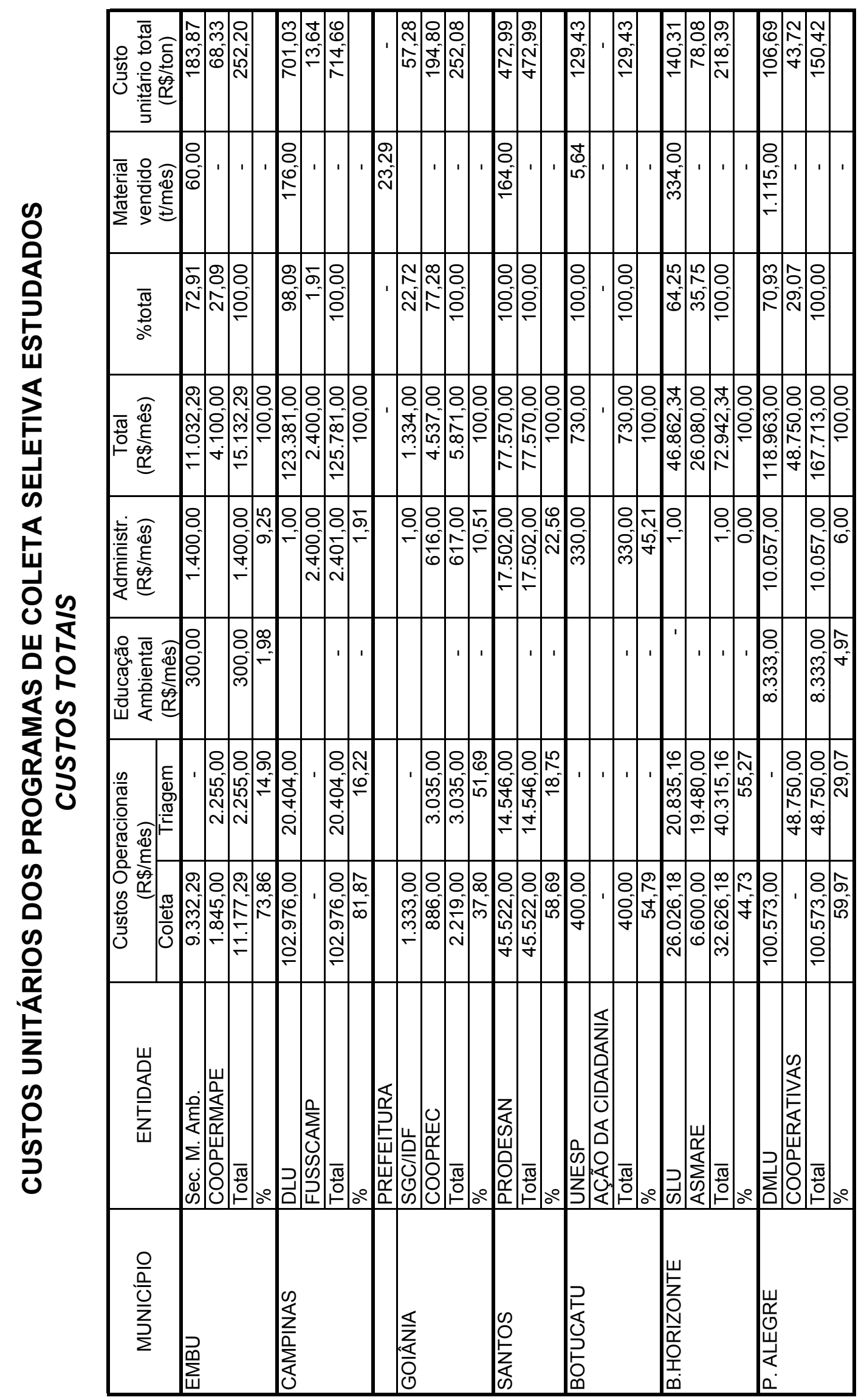




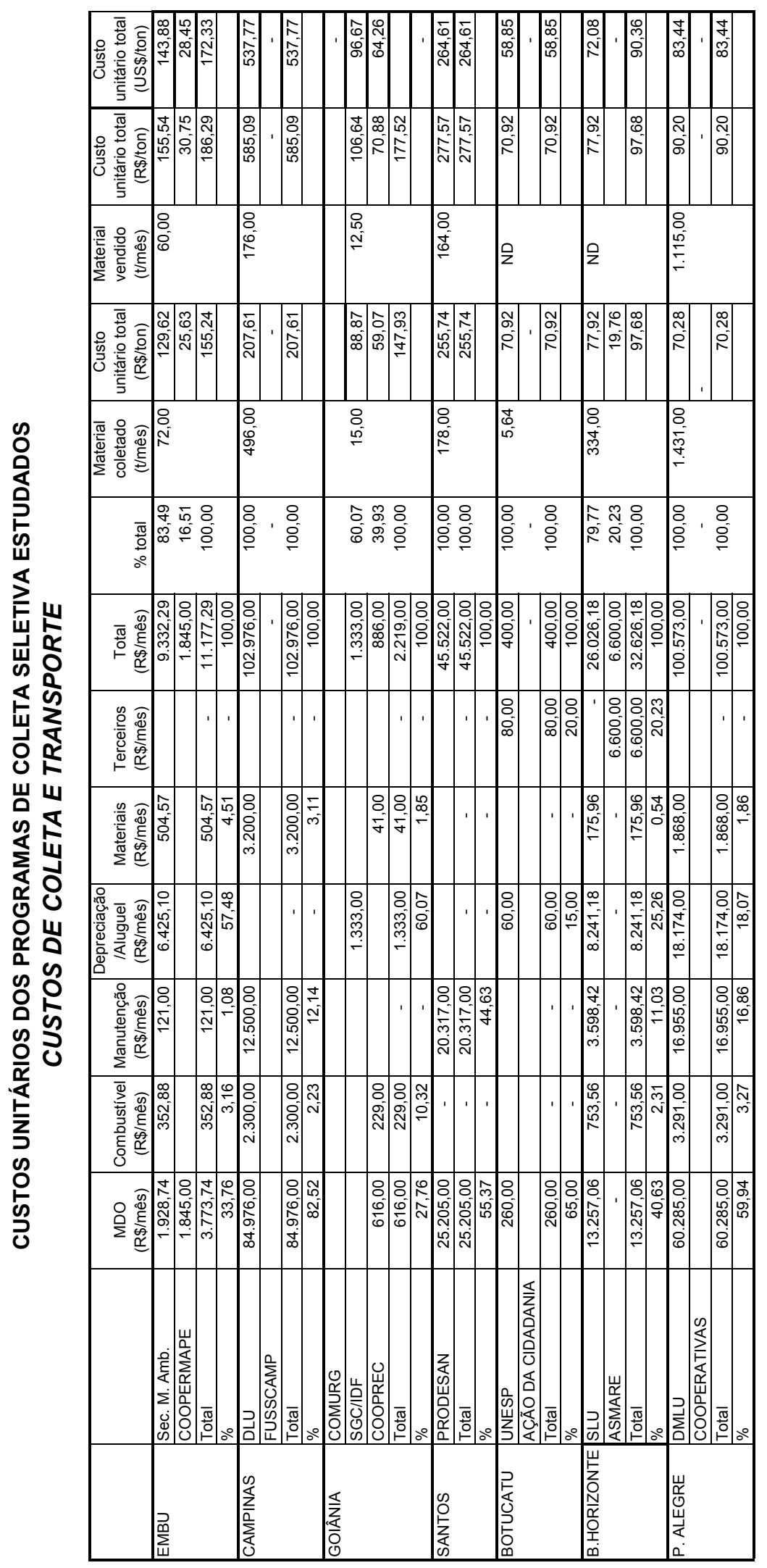




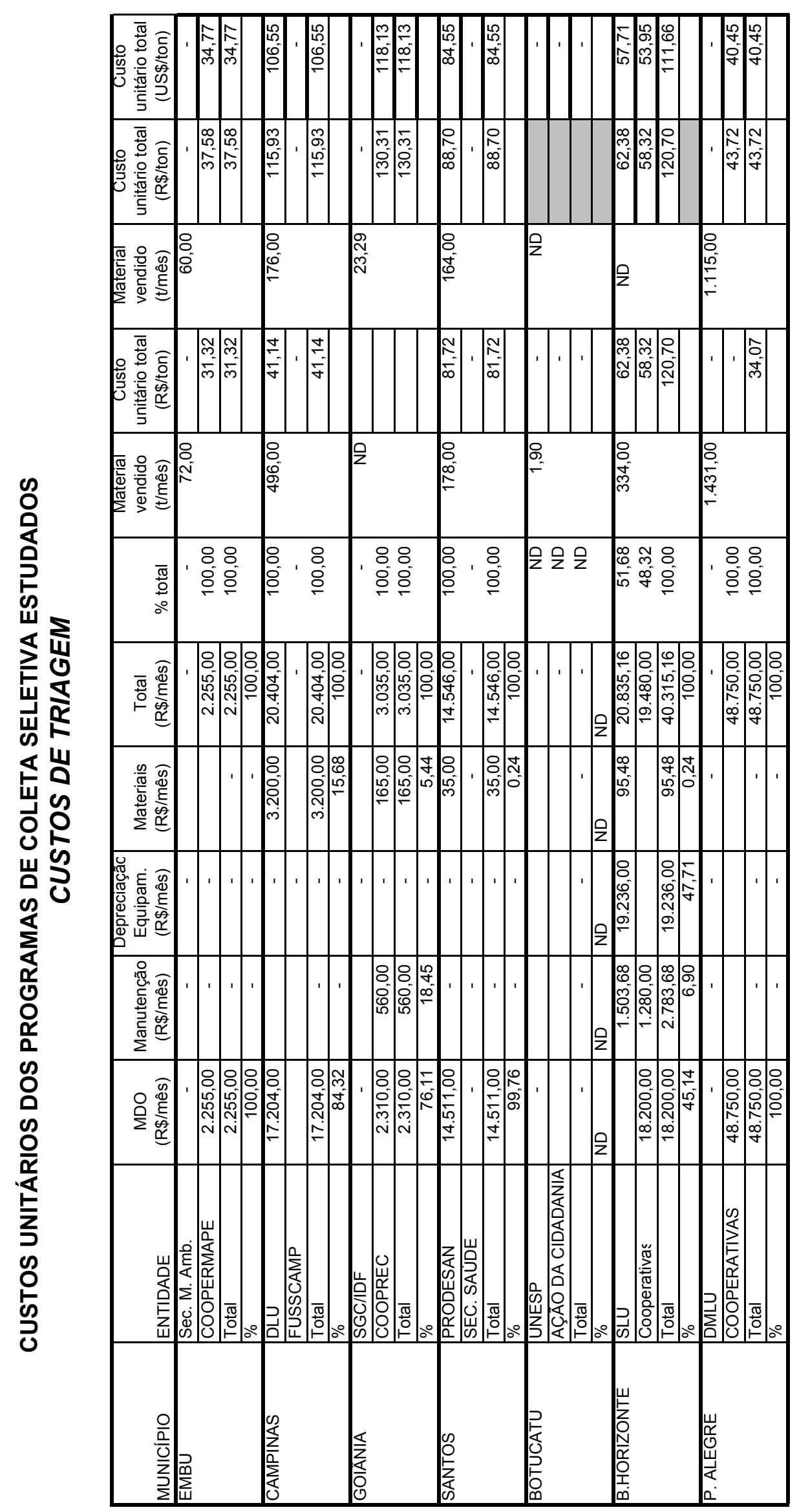




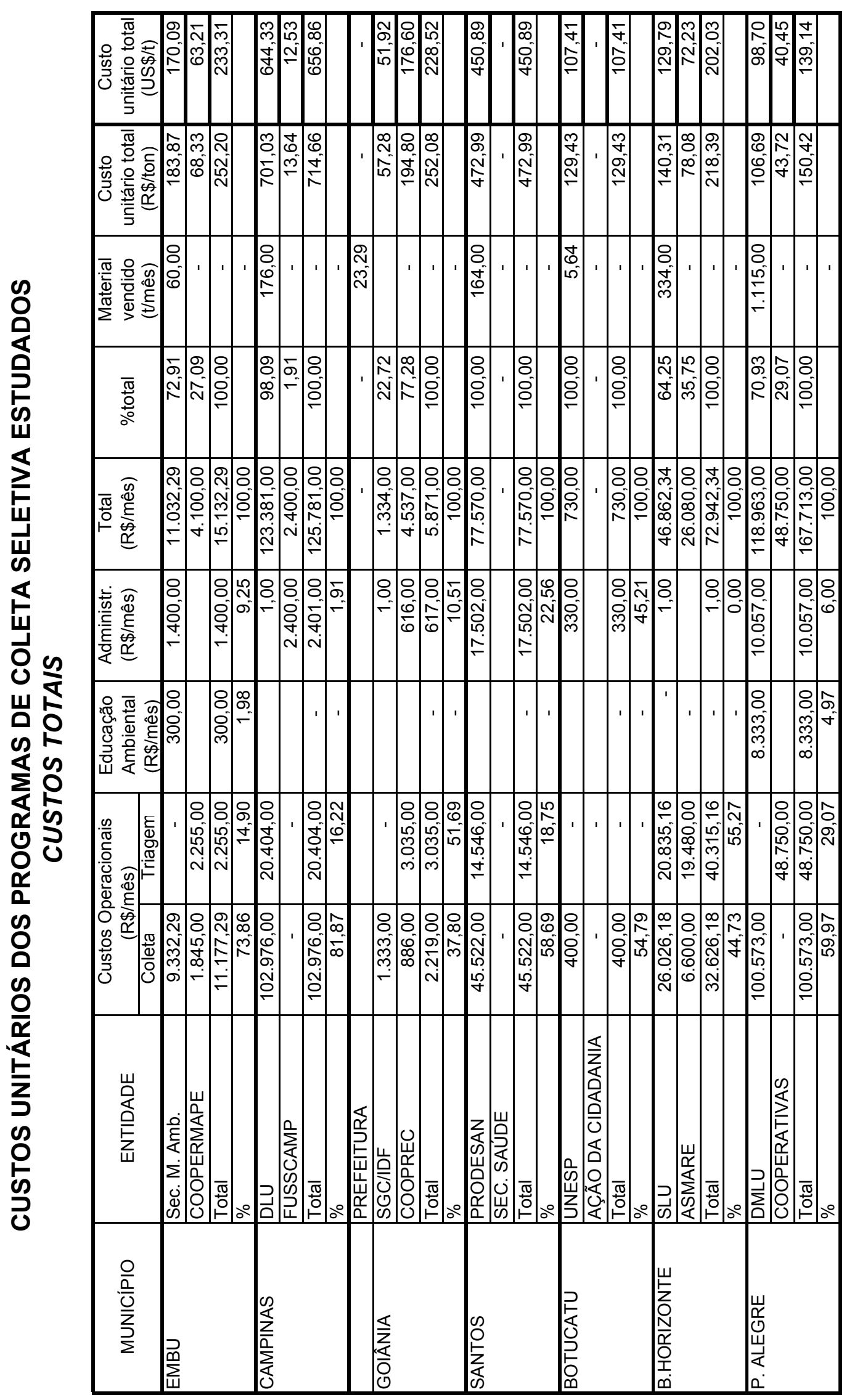




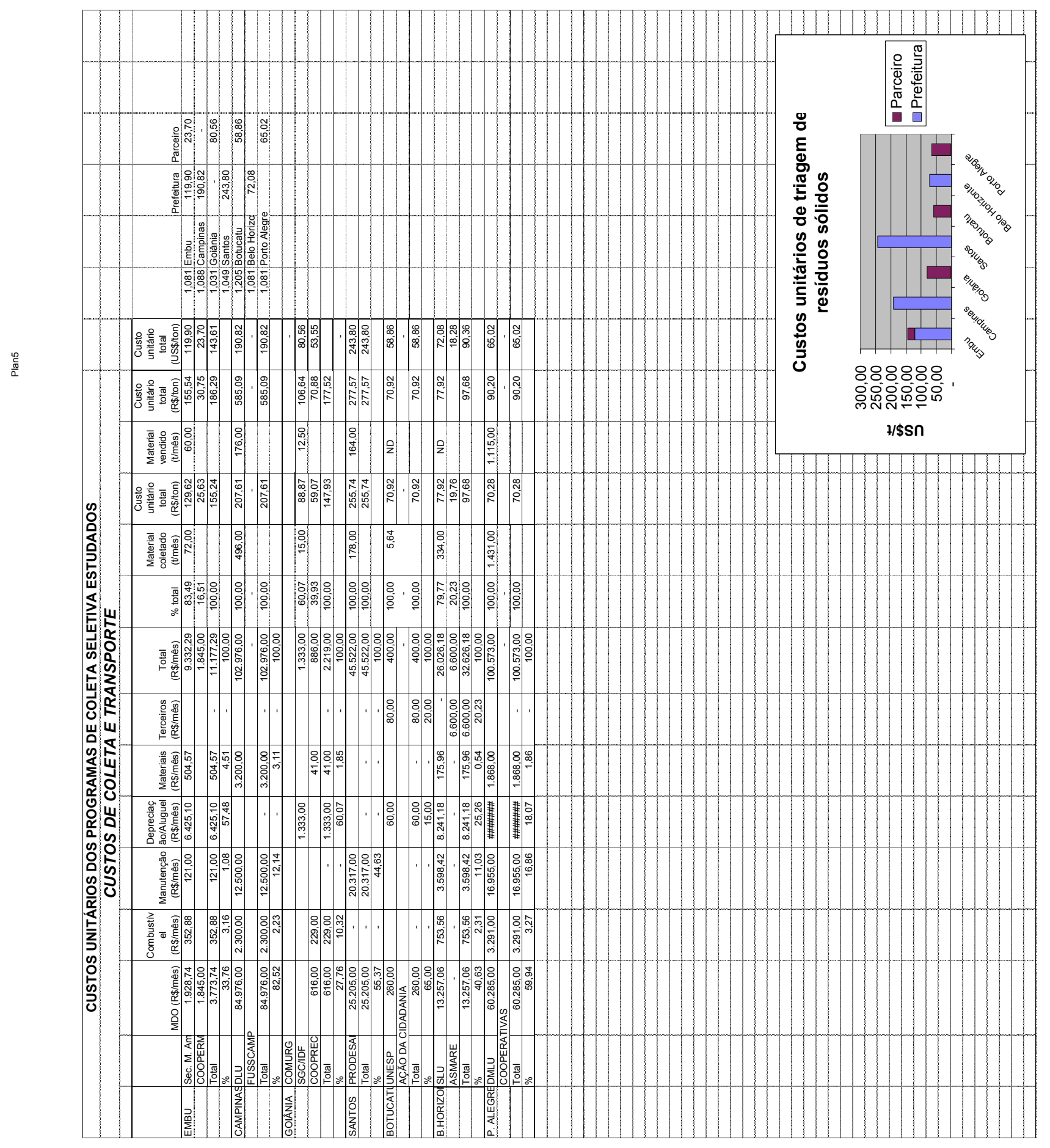



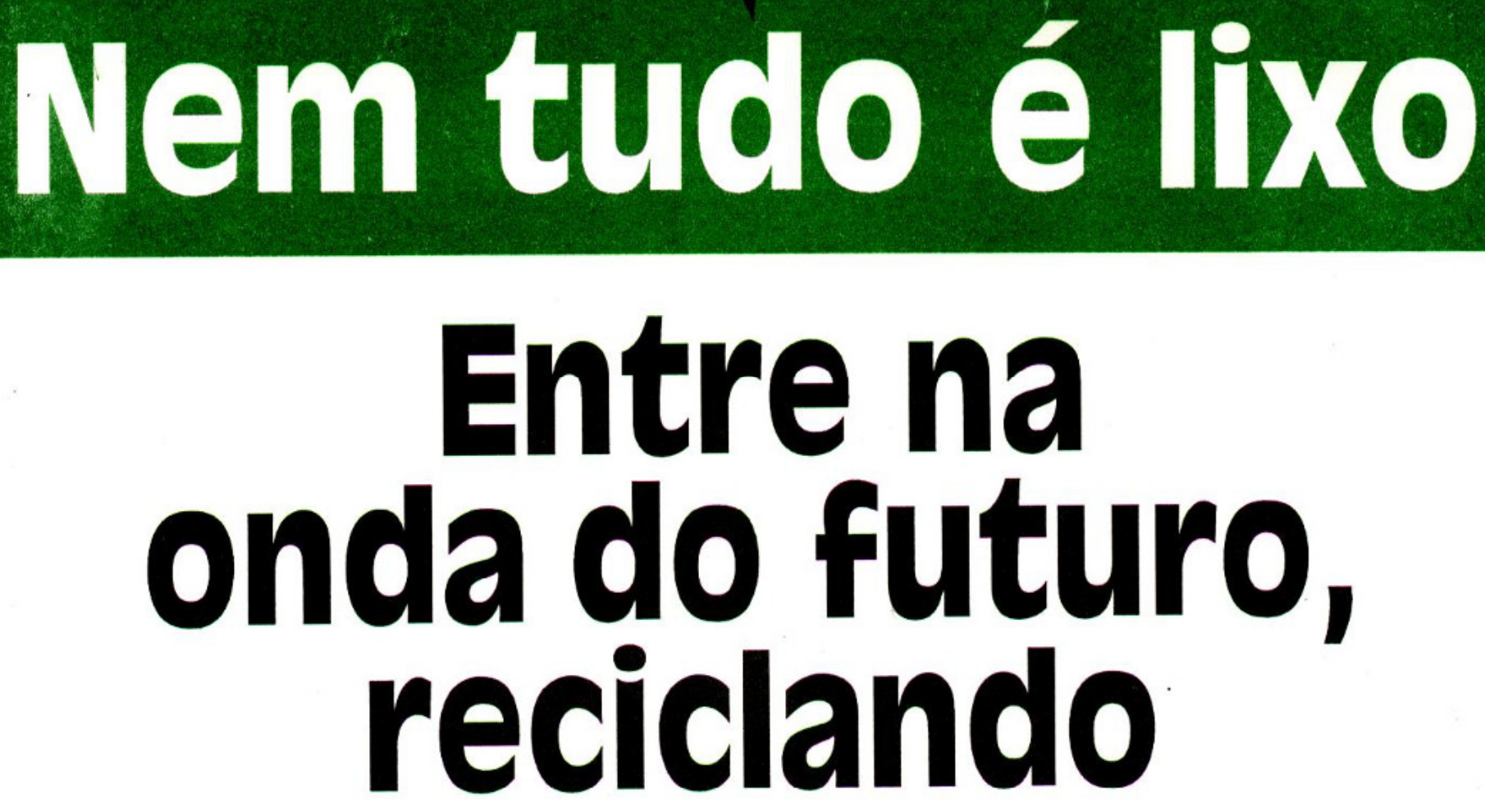

É só separar os materiais recicláveis $e$ entregar ao caminhão da COLETA SELETIVA, que passa um dia por semana na sua porta.
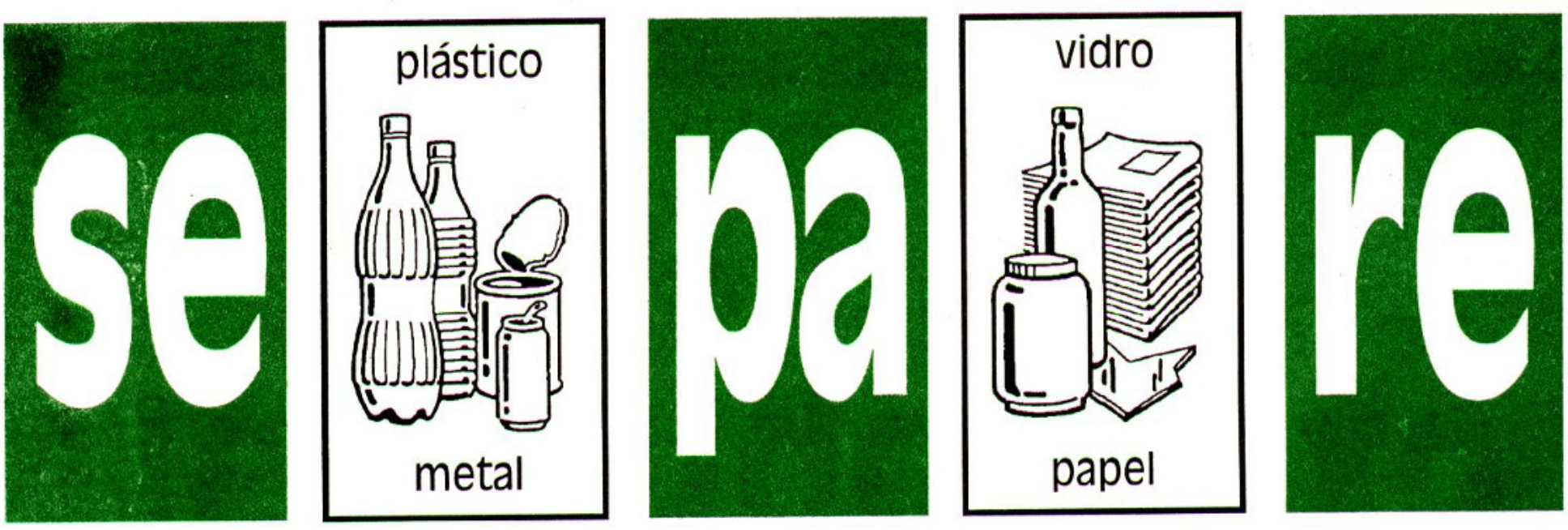

coloque todos os materiais em sacos plásticos ou caixas de papelão, limpos e secos.

PREFEITURA DA ESTÂNCIA TURÍSTICA DE EMBU

Administrando para o futuro

SECRETARIA MUNICIPAL DO MEIO AMBIENTE 


\begin{tabular}{|c|c|c|}
\hline DIA DA SEMANA & BAIRRO & $\begin{array}{l}\text { Início } \\
\text { Horário } \\
\text { Coleta }\end{array}$ \\
\hline \multirow{2}{*}{ Segunda - feira } & Estuário - Área 1/ Piratininga / São Manoel / Alemoa & shoo \\
\hline & Boqueirão / Encruzilhada & 14 hoo \\
\hline \multirow[t]{2}{*}{ Terça - feira } & $\begin{array}{l}\text { Santa: Maria / Bom Retiro / Vila Belmiro / Valongo } \\
\text { Morro Sảo Bento / Vila São Bento / Boa Vista / Pacheco } \\
\text { Gonzaga (zona comercial) }\end{array}$ & 8 hoo \\
\hline & Campo Grande - Area 2 & $14 \mathrm{~h} 00$ \\
\hline \multirow{2}{*}{ Quarta - feira } & Vila Nova / Centro / Jardim Castelo & $8 \mathrm{~h} 00$ \\
\hline & Marapé / Gonzaga (zona comercial) & $14 h 00$ \\
\hline \multirow{2}{*}{ Quinta - feira } & $\begin{array}{l}\text { Rádio Clube / Vila Săo Jorge / Chico de Paulo } \\
\text { Jabaquara / Monte Serrat }\end{array}$ & $8 \mathrm{ho0}$ \\
\hline & José Menino/ Gonzaga / Bairro Gonzaga (zona comercial) & 14 hoo \\
\hline \multirow{2}{*}{ Sexta - feira } & Vila Mathias / Areia Branca / Gonzaga (zona comercial) & 8 hoo \\
\hline & Embare / Aparecida & 14 hoo \\
\hline \multirow[t]{2}{*}{ Sábado } & Caneleira/Sapoo / Paqueta & $8 \mathrm{~h} 00$ \\
\hline & Porta da Praia / Gonzaga (zona comercial) Nova Cintra & 14h0o \\
\hline Segunda-feira a Sábado & Macuco - Coleta feita pelos trabalhadores ecológicos. & \\
\hline \multicolumn{3}{|c|}{ CORES QUE IDENTIFICAM OS MATERIAIS RECICLÁVEIS } \\
\hline
\end{tabular}

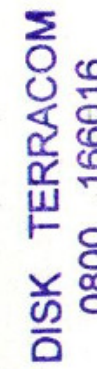

POR QUE NÃO JOGAR ESTE FOLHETO NO LIXO? Este folheto pode ser reciclável, por isso não o misture com o lixo doméstico, ao invés disso passe-o para um amigo.

Se você gostou, ligue para a gente na Secretaria do Meio Ambiente dando sua impressão e sugestões.

Lembre-se, a melhora da qualidade de vida depende de nós.

APOIO:

A. Tetra Pak Mais que a embalagem

Diprodesan
$=$
SANTOS

VOCÊ PODE FAZER COM QUE NOSSA CIDADE TENHA UMA QUALIDADE DE VIDA AINDA MELHOR

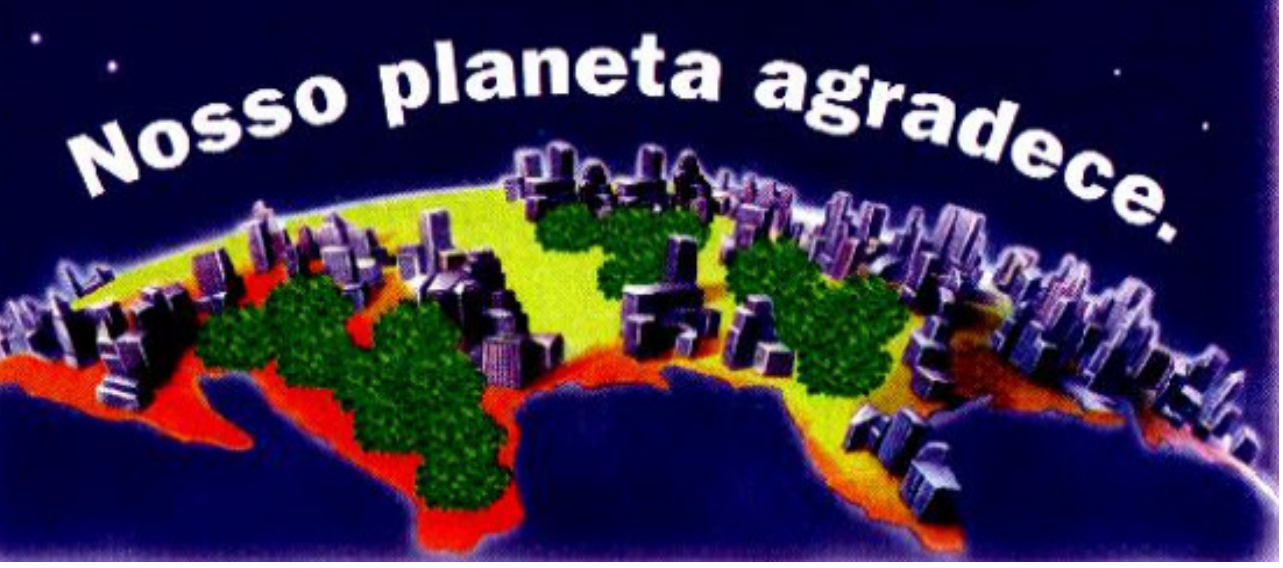




\section{O QUE DEVE SER SEPARADO \\ PARA A RECICLAGEM}

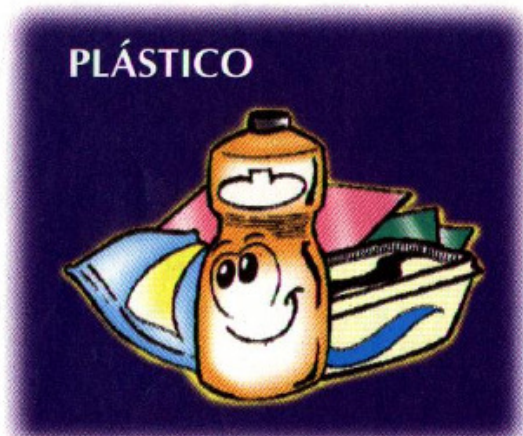

Plásticos duros e moles, embalagens de re-

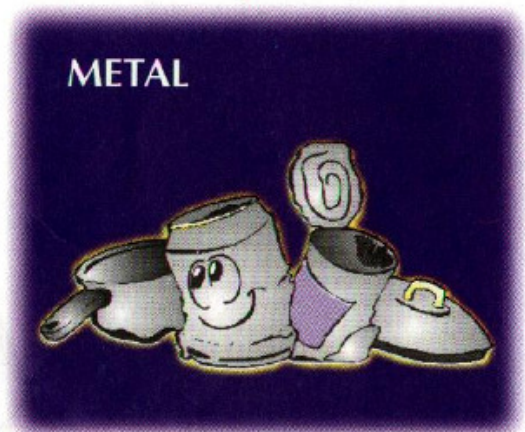

Latas de alumínio, latas de aço, casco de geladeira, fios, fogão, cadeiras de praia, uten-
sílios de ferro, arames, pregos e tampas. frigerante, detergente, xampu, margarina.

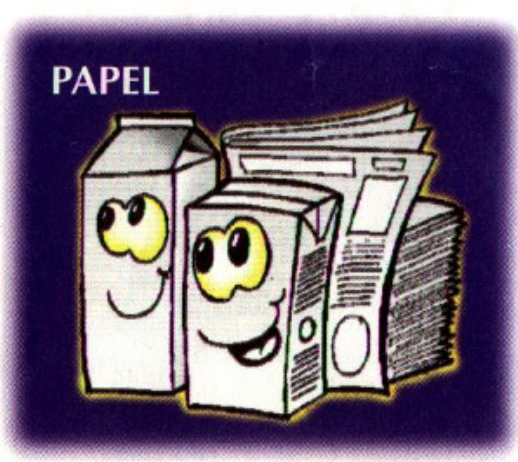

Jornais, revistas, papelão, cadernos, caixas, papel de computador, cartôes, cartolina, formulários contínuos, embalagens longa formu
vida.

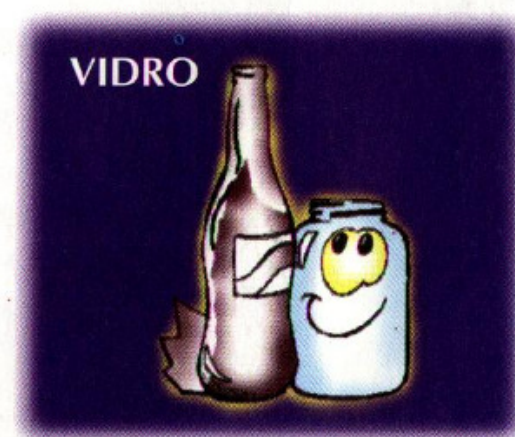
Potes, frascos, garrafas, cacos de vidro. Es-
tes materiais são chamados de recicláveis ou lixo limpo.

\section{IMPORTANTE:} e secos. Sempre que possivel diminua o volume, amassando latas, papéis e papelões. Deposite-os no Posto de Entrega Voluntária mais próximo de você.
Esses materias devem estar limpos

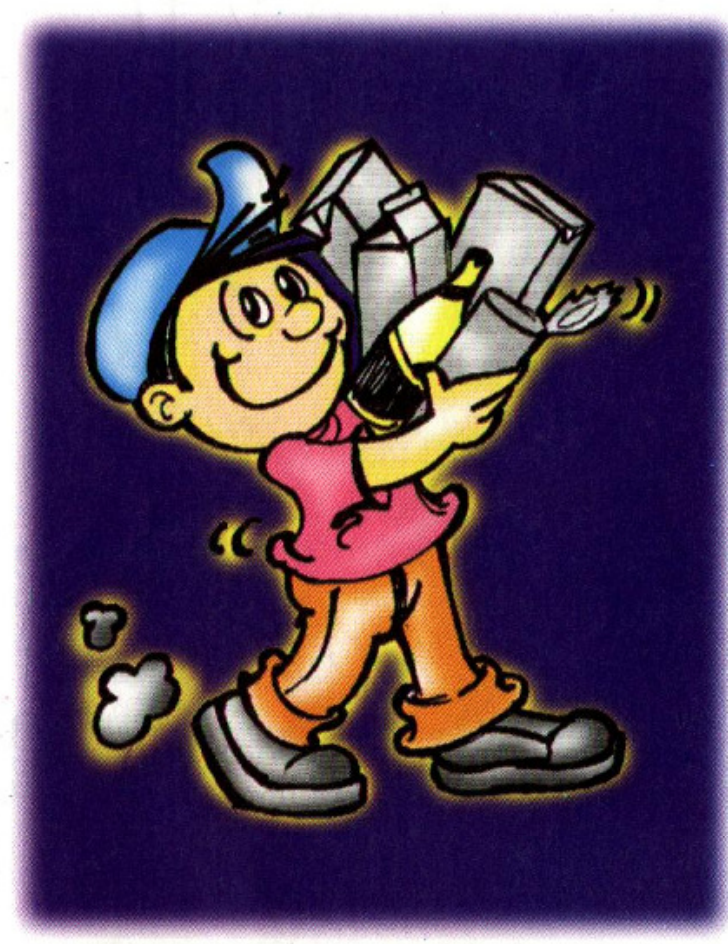

\section{QUAIS OS BENEFÍCIOS QUE O PROGRAMA DE RECICLAGEM TRAZ?}

Economia de energia e matéria-prima. Menor poluição do ar, da água e do solo.

Melhora a limpeza da cidade, pois o morador que adquire o hábito de separar o lixo dificilmente o joga nas vias públicas.

Gera renda pela comercialização dos recicláveis. Diminui o desperdício.

Gera empregos para os usuários dos programas de saúde e programas sociais da prefeitura.

Dá oportunidade aos cidadãos de preservarem a natureza QUE NÃO DEVE SER SEPARADO

Roupas, retalhos, isopor, papéis sujos, lâmpadas, pilhas, louças, pirex, porcelana, remédios, seringas,

\section{COMO PARTICIPAR DESSE DESAFIO?}

É fácị!! Tenha sempre duas lixeiras na sua casa: uma para materiais recicláveis (lixo limpole outra para os não recicláveis (restos de comida).

Depois, é só entregar para a coleta seletiva ou para a coleta de lixo comum de seu bairro.

Os Postos de Entrega Voluntária distribuídos pela cidade também são uma opção para vocé entregar os materias recicláveis.

Se você mora em prédio ou condomínio e não tem um programa de coleta seletiva organizado, năo perca tempo, ligue para a SEMAM no telefone: 235thorar sua qualidade de vida.

O QUÊ VOCÊ PODE FAZER PARA COLABORAR COM O MEIO AMBIENTE?

Evite o desperdício! Reutilize materiais e separe aqueles que podem ser reciclados.

VIU COMO É FÁCIL?

Atitudes e hábitos como estes, trazem resultados efetivos para meIhorar a qualidade de vida.

Experimente este desafio! A natureza agradece.

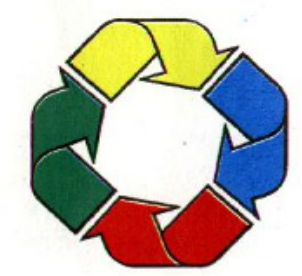



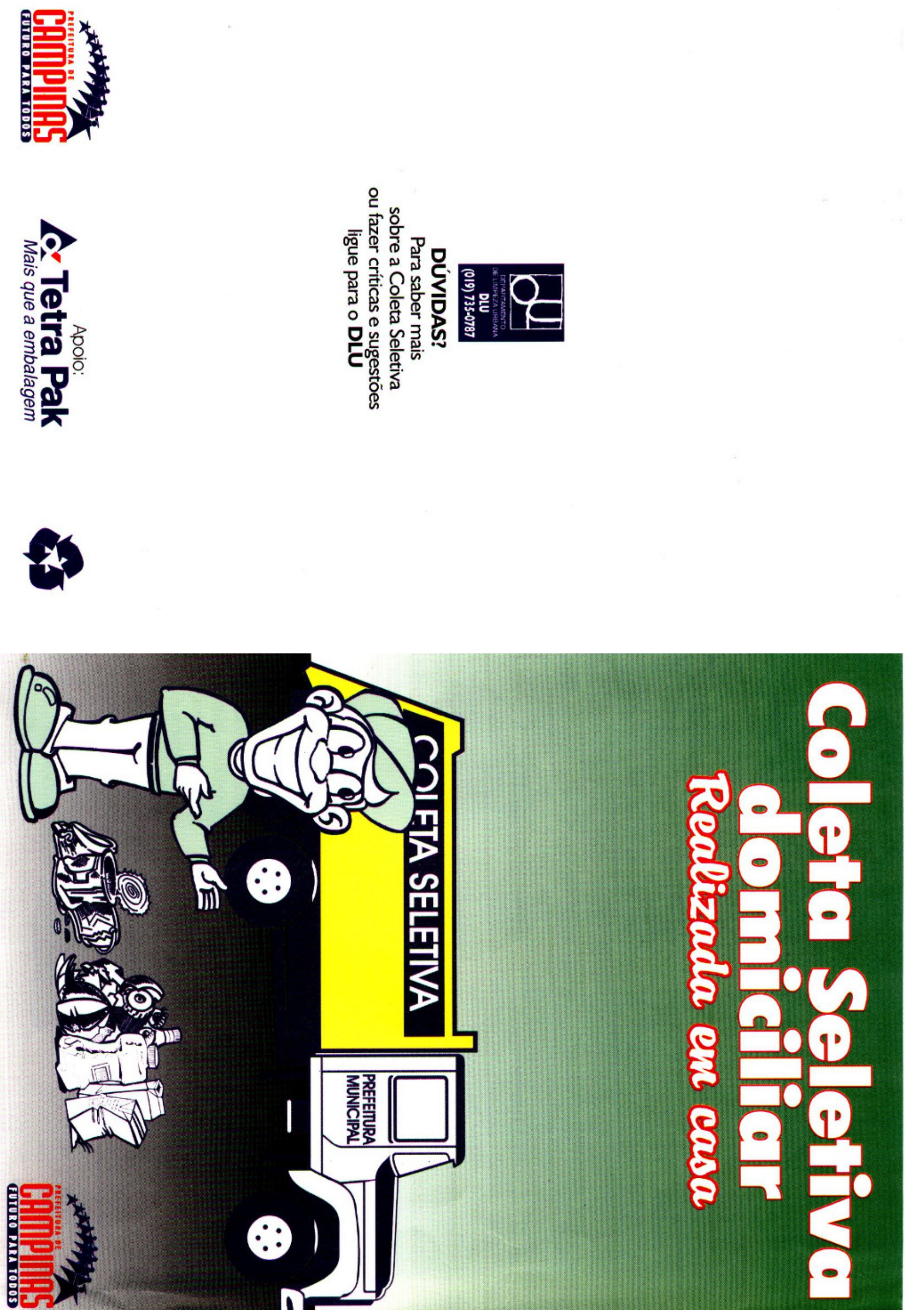

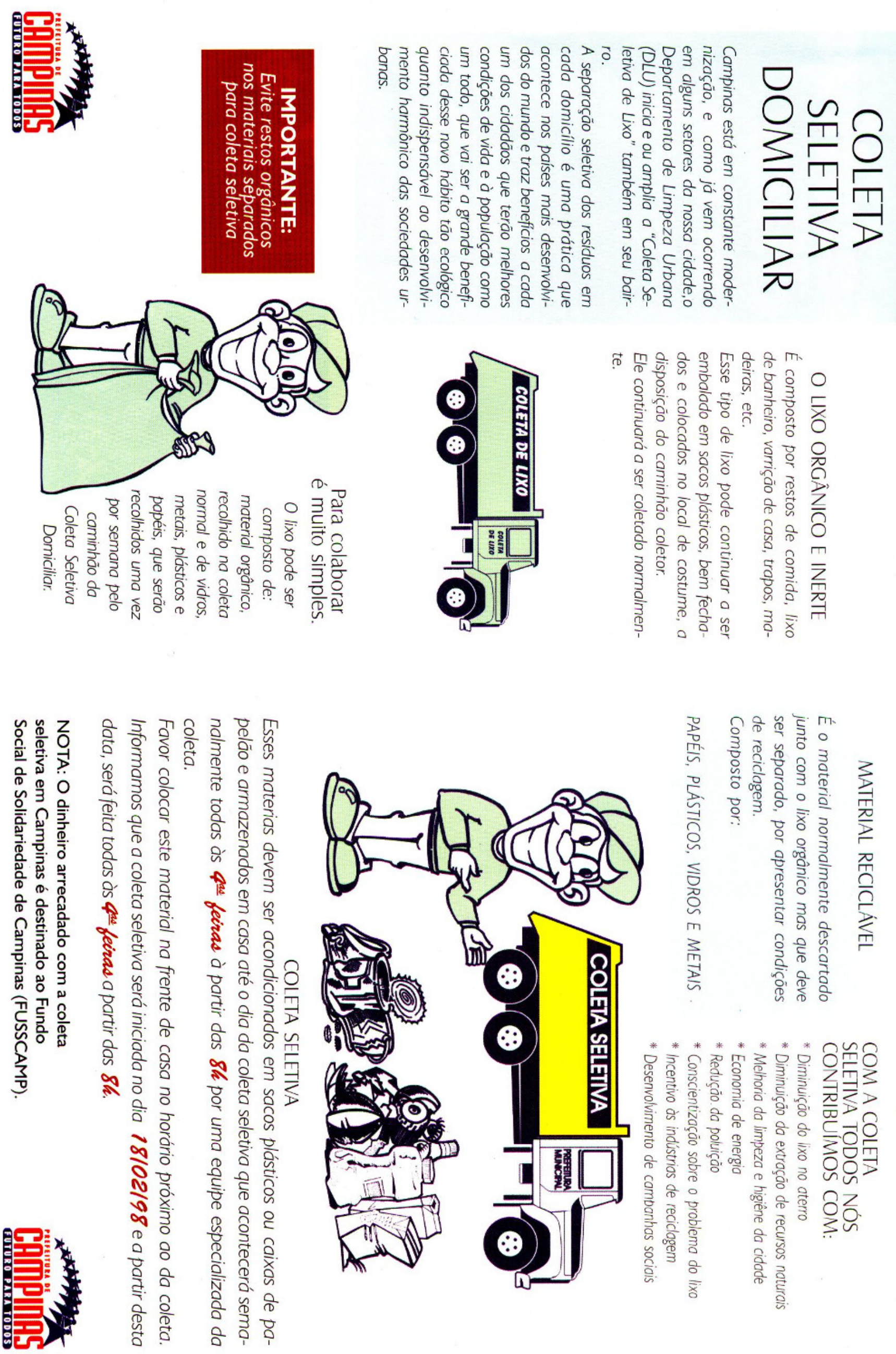


\section{ANEXO VIII}

Modelos de cartas de apresentação e de consentimento esclarecido 



\section{Universidade de São Paulo Faculdade de Saúde Pública Departamento de Saúde Ambiental}

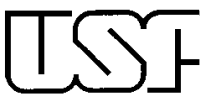

IImo. Sr. (a)

Av. dr. Arnaldo, 715 - São Paulo - SP - Tel. 3066-7712

São Paulo, de

de 1999.

Prezado(a) Senhor(a):

Para fins de trabalho acadêmico de pós-graduação, estamos realizando uma série de entrevistas com pessoas que trabalham em empresas, entidades e instuições envolvidas direta ou indiretamente em gerenciamento de resíduos sólidos domésticos. Esta pesquisa tem o objetivo de analisar a participação das entidades e instituições no gerenciamento de resíduos sólidos domésticos, suas dificuldades e as soluções criativas que encontram.

Pelas informações prévias que obtivemos sobre o trabalho desta instituição, seria extremamente valioso para nós contar com dados desta instituição, e por isto solicitamos sua colaboração no sentido de viabilizar as entrevistas necessárias, e autorização para publicação dos dados coletados. Esclarecemos que não estamos avaliando individualmente o comportamento de pessoas, portanto nos comprometemos a manter total respeito e sigilo quanto aos nomes das pessoas entrevistadas, bem como sobre seus dados pessoais.

Permanecemos à disposição para esclarecer eventuais dúvidas.

Gratos,

Arlindo Philippi Jr.

Orientador
Alexandre Aguiar.

Pesquisador 
DECLARAÇÃO DE CONSENTIMENTO ESCLARECIDO

(INDIVIDUAL)
São Paulo,
de
de 1998.

$\mathrm{Eu}$

(nome)

(doc. Identidade) declaro para os devidos fins que autorizo a

utilização dos dados coletados na entrevista realizada nesta data pelo sr. Alexandre de Oliveira

e Aguiar, para fins de trabalhos acadêmicos e publicações, sem restrições de prazos e citações, desde a presente data.

Abdicando de direitos meus e de meus sucessores, subscrevo a presente.

Data e local, 